\title{
ROSA AURILAVRADA: \\ figurações da utopia em A Rosa do Povo versão corrigida
}

MARCELO FREITAS FERREIRA DE OLIVEIRA

Dissertação apresentada ao Programa de Pós-Graduação em Teoria Literária e Literatura Comparada da Faculdade de Filosofia, Letras e Ciências Humanas da Universidade de São Paulo, para obtenção do título de Mestre em Letras.

Orientação | Profa. Dra. lumna Maria Simon

São Paulo

2014 
FACULDADE DE FILOSOFIA, LETRAS E CIÊNCIAS HUMANAS DEPARTAMENTO DE TEORIA LITERÁRIA E LITERATURA COMPARADA

\section{ROSA AURILAVRADA: \\ figurações da utopia em $A$ Rosa do Povo versão corrigida}

MARCELO FREITAS FERREIRA DE OLIVEIRA

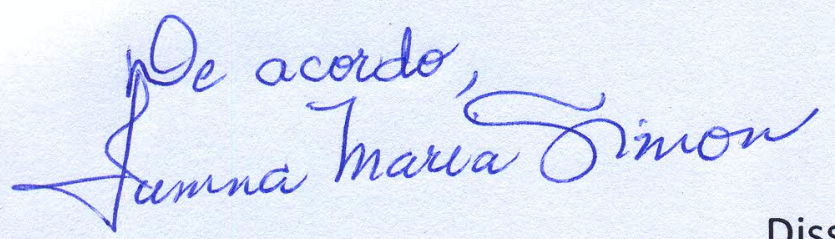

Dissertação apresentada ao Programa de Pós-Graduação em Teoria Literária e Literatura Comparada da Faculdade de Filosofia, Letras e Ciências Humanas da Universidade de São Paulo, para obtenção do título de Mestre em Letras.

Orientação |Profa. Dra. lumna Maria Simon 
Para Roberta 


\section{AGRADECIMENTOS}

À Iumna, pela orientação sempre generosa e estimulante, e pela confiança desde minhas primeiras aulas na Faculdade de Letras.

A Betina Bishof e Murilo Marcondes de Moura, pela arguição em meu exame de qualificação, dando sugestões valiosas para os rumos da pesquisa.

À Lilian Jacoto, pela amizade e pelas trocas sempre vivas e afetuosas.

Ao Danilo Bueno, amigo que compartilhou de perto muitas das leituras e descobertas durante a pesquisa.

A Carolina Serra Azul e Renan Nuernberger, pelo compartilhamento de leituras, de ensaios, de livros, sempre estimulante e marcado pelo afeto.

A Simone e Sérgio Lucena, pela amizade, pelo gosto na leitura dos poemas e pelo ânimo com os rumos da pesquisa.

A Morgana e Diana, pelo companheirismo sem fim.

À Roberta, companheira perfeita, eterna, que compartilhou cada linha deste trabalho, lendo, debatendo, estimulando sempre novas reflexões. À minha Rosa, dedico este estudo. 


\section{RESUMO}

Este estudo busca evidenciar a natureza utópica de A Rosa do Povo, explorando algumas das tensões que envolvem o processo de constituição do sujeito lírico, dentre as quais destaco: a problemática da projeção do sujeito para o espaço público da "rua", em poemas que se tornam longos para dar lugar às diferentes vozes da coletividade, face ao resguardo de certa autonomia descompromissada do eu poético; as relações entre lírica e sociedade, diante das exigências político-sociais da década de 1940. Essas tensões são lidas sob o enfoque do conceito da utopia, que possibilita verificar, em cada poema analisado, uma mensagem poética específica, a um só tempo crítica e esperançosa. Ainda que cada composição seja lida como fragmento autônomo, os poemas também se articulam no conjunto da obra, simbolizada pela "rosa". A interpretação dessa imagem, que se repete ao longo do livro e condensa a sua multiplicidade temática, permite ao leitor uma visão do todo. Procuramos demonstrar como esse processo de construção poética acaba por evidenciar também o uso simbólico de operações alquímicas, de modo que se possa compreender a obra como uma espécie de 'utopia alquimista', inserida que está num processo ininterrupto de materialização e desconstrução do canto, a refletir a concepção drummondiana acerca da precariedade do poético.

Palavras chave: Carlos Drummond de Andrade, A Rosa do Povo, utopia, linguagem, experiência, alquimia. 


\section{ABSTRACT}

The purpose of this research is to show the utopic nature of A Rosa do Povo, exploring some of the tensions that involve the development process of the liric subject in which among others I would highlight: the projection of the public space in poems that last long to make possible a multiplicity of voices of colective, in face of the uncompromissed autonomy of the poetic subject; the acqward relationship between liric and society, in face of the social politcs needs of the 1940 forties. These tensions are understood, over the concept of the utopic society, that allows us to verify, in each of the researched poem, a specific poetic message, at the same time critic and full of hope. Even understood as an autonom fragment, each one of the poem gather in the whole of the book, represented by the "rose". This image interpretation, that come over all long the book, condense the tematic multiplicity and allows the reader a sight of the whole of the book. We seek to demonstrate how this process of poetic construction ends up also highlighting the symbolic use of alchemical operations so that we can understand the work as a kind of 'alchemist utopia', part of an uninterrupted process of materialization and deconstruction of the poem, that reflects the drummondiana's conception of the precariousness of the poetic.

Key-words: Carlos Drummond de Andrade, A Rosa do Povo, utopia, language, experience, alchemy. 


\section{SUMÁRIO}

Considerações preliminares.....................................................................................

\section{Enunciação da utopia da rosa}

1.1. Impulso afirmativo: "Consideração do poema". .17

1.2. Tensão sob ambiguidade: "Procura da poesia"...... 35

1.3. Dissolução na noite: "Anoitecer" .46

2. Mergulho na individualidade: dissolução do mundo coagulado

2.1. Utopia do resgate da infância: "Nos áureos tempos"....................................55

2.2. Utopia da vida mínima: "Vida menor" e "Campo, chinês e sono"...............75

2.3. Desejo, corpo, utopia: "O mito" .93

\section{Encontro com o coletivo}

3.1. Visão local: "Morte do leiteiro".

3.2. Visão internacional: "Carta a Stalingrado".

4. A utopia da rosa

4.1. A rosa aurilavrada: "Anuncio da Rosa" 144

4.2. A rosa do povo aberta: "Mario de Andrade desce aos infernos".. 158

4.3. Renovação das palavras: "Canto ao homem do povo Charlie Chaplin". .170

Conclusão 186

Bibliografia 190 


\section{Considerações preliminares}

Os poemas de A Rosa do Povo (1945) foram escritos por Carlos Drummond de Andrade entre 1943 e 1945, no contexto da Segunda Guerra e da ditadura do Estado Novo, abordando uma multiplicidade de temas, entre eles: o ofício poético, na sua intrincada relação com as palavras; as questões sociopolíticas; o passado mineiro e as relações do sujeito com a memória familiar; o desejo, no seu vínculo irrevogável com o corpo. Observamos, também, que muitos poemas da coletânea são marcados por um forte componente utópico, quer como crítica radical à realidade objetiva, quer como projeção esperançosa de um futuro melhor, quer, ainda, enquanto vontade de composição de um poema socializante. A fortuna crítica do livro concentrou-se especialmente na análise da temática político-social, que envolve a noção de uma poesia engajada, o que é de enorme relevância para a compreensão do livro e do contexto histórico em que foi escrito. Por meio deste estudo, pretendemos ampliar a discussão, trazendo temas e simbologias ainda pouco analisados.

Utilizaremos o conceito da utopia como instrumento para leitura da obra, não só devido à sua amplitude e complexidade, como também pelo fato de o início da década de 40 corresponder, segundo o célebre historiador desse conceito, Bronislaw Baczko, a um período 'quente', “em que a criatividade utópica se intensifica e as utopias mantêm relações particularmente intensas com os movimentos sociais, as correntes ideológicas, o imaginário colectivo, etc." (BACZKO, 1985, p. 355). Além disso, devido ao constante intercâmbio de temas entre a poesia e a prosa drummondianas, recorreremos frequentemente à leitura das crônicas de Confissões de Minas (1944) e Passeios na Ilha (1952), para tentar desvendar poemas de A Rosa do Povo, com conteúdos muitas vezes cifrados. ${ }^{1}$

Vale lembrar que, na década de 30, passou a existir no Brasil um movimento de polarização ideológica entre "direita" e "esquerda", que exigia aos intelectuais um posicionamento político, fato

\footnotetext{
${ }^{1}$ João Adolfo Hansen comenta sobre a importância da prosa drummondiana para a elucidação de poemas herméticos do mineiro: "Uma leitura paciente de toda a sua prosa que a compare com sua poesia encontrará mais evidências desse trânsito dos temas de um campo para outro e poderia ser útil, quem sabe, para elucidar o sentido de formulações condensadas e por vezes herméticas de muitos poemas" (HANSEN. In: DRUMMOND DE ANDRADE. 2011a, p. 268).
} 
até então inédito na sociedade brasileira. ${ }^{2}$ Nessa ocasião, a falta de um posicionamento político de Drummond ganhava contornos cada vez mais tensos, como em seu livro de 1934, Brejo das Almas, cuja poética, conforme mostrou Vagner Camilo, seria marcada "pelo conflito resultante da indecisão do poeta em face das exigências de alinhamento político-ideológico da intelectualidade nos anos 1930" (CAMILO, 2000, p. 37).

Uma nova fase da poesia drummondiana surge com a publicação de Sentimento do Mundo (1940), livro em que o poeta incorpora as experiências decorrentes da transformação de sua vida, dos novos contatos e contágios com a mudança de Belo Horizonte para o Rio de Janeiro, acrescentando à vivência individual o sofrimento pelos homens. ${ }^{3}$ A poética participativa da década de 40 passa a ser de recusa à solidão, como se esta gerasse a ruína do indivíduo, a sua pobreza, bem como de recusa a uma postura de absenteísmo político. Por isso a necessidade de incorporação do tempo, de comunicação, de engajamento na construção de um futuro.

A poética de incorporação dos ideais da coletividade alcança o seu ápice em $A$ Rosa do Povo, mas sempre impregnada pela tensão que envolve a 'função social' da poesia e do poeta. Os poemas do livro de 45 atestam, de um lado, um movimento de 'participação', que reflete não só uma postura contemporânea de diálogo com seu tempo e de intervenção nos acontecimentos, mas também um entendimento do poema enquanto dissolvente, catalisador e reorganizador do real; ou seja, o poema enquanto matéria autônoma que, a partir de si mesma, nomeia o mundo. E, de outro lado, vemos um movimento de 'recusa', que parte da compreensão do lugar íntimo e solitário da experiência poética, repercutindo, às vezes, numa espécie de sentimento de 'impossibilidade' ou de ‘inutilidade' do poema. Essa poética pendular é apresentada nos dois primeiros poemas do livro,

\footnotetext{
${ }^{2}$ No ensaio "A Revolução de 30 e a cultura", Antonio Candido discorreu acerca desse contexto: "Isto, que era antes excepcional no Brasil, se generalizou naquela altura, a ponto de haver polarização dos intelectuais nos casos mais definidos e explícitos, a saber, os que optavam pelo comunismo ou pelo fascismo. Mesmo quando não ocorria esta definição extrema, e mesmo quando os intelectuais não tinham consciência clara dos matizes ideológicos, houve penetração difusa das preocupações sociais e religiosas nos textos" (CANDIDO, 2006a, p. 227).

${ }^{3}$ É o que se pode ler nos seguintes versos do poema "Mundo grande", de Sentimento do mundo: "(Na solidão de indivíduo / desaprendi a linguagem / como que os homens se comunicam.) (...) Outrora escutei os anjos, / as sonatas, os poemas, as confissões patéticas. / Nunca escutei voz de gente. / Em verdade sou muito pobre (...) Então, meu coração também pode crescer". Neles o eu lírico reconhece que o seu coração é menor que o mundo, e por isso carece de todos os homens, precisando escutar a voz deles, caminhando juntos de "mãos dadas", diferentemente aos versos do "Poema de sete faces", do seu livro de estreia, Alguma poesia (1930): "Mundo mundo vasto mundo,/ mais vasto é o meu coração".
} 
“Consideração do poema" e "Procura da poesia", que, no primeiro capítulo, são analisados juntamente com o poema "Anoitecer", o qual introduz a temática do noturno no conjunto da obra.

Nesta oscilação entre compromisso e autonomia, notamos ainda o caráter processual do livro. Os poemas são lidos individualmente, como partes autônomas, ao mesmo tempo em que se articulam no conjunto da obra, a ser lida também como um todo, simbolizado pela "rosa", que, no poema "Anúncio da rosa", é definida como "aurilavrada", justificando-se, assim, a expressão utilizada no título da dissertação, "rosa aurilavrada". Alguns poemas da obra remetem, por exemplo, a diferentes períodos do dia ou a estações do ano, como "Consideração do poema", "Anoitecer", "Versos à boca da noite", "Passagem da noite", "Morte do leiteiro", buscando uma reaproximação simbólica junto aos ciclos naturais. Concomitantemente, é possível observar, nesse processo de escrita, a busca pela constituição de um sujeito poético utópico, cuja característica de 'autonomia descompromissada', em relação às questões político-sociais, vem a converter-se, mesmo que de maneira oscilante, num eu aberto à alteridade. Ressalto que a estruturação dos capítulos da dissertação busca evidenciar a leitura que faço acerca da natureza processual de $A$ Rosa do Povo, o que não corresponde, de certa maneira, à ordem cronológica dos poemas no livro. No segundo capítulo, analisamos poemas que exploram questões de natureza individual. Inicialmente o poema "Nos áureos tempos", que faz o movimento de rememoração da infância, reabrindo esse espaço-tempo idealizado, e projetando, no futuro, o retorno das qualidades 'auríferas' de uma infância simbólica. Em seguida, passamos à análise de "Vida menor" e “Campo, chinês e sono", poemas em que o sujeito lírico procura certa 'autonomia', solitária e desimpedida de sua função social; mas ao analisarmos tais composições no conjunto da obra, vemos que elas metaforizam, também, um movimento de ‘depuração' do canto, de 'recolhimento estratégico' num ambiente 'miniaturizado', em que o eu lírico se concentra numa ideia de 'essência', de 'semente', para depois retomar o canto socializante. Analisamos, enfim, o poema "O mito", mostrando o impasse do sujeito na tentativa de superação do desejo, que se vincula ao corpo, por meio da poesia. 
No terceiro capítulo, são analisados os poemas "Morte do leiteiro" e "Carta a Stalingrado". O primeiro retrata um drama ocorrido no Rio de Janeiro, alegorizando o conflito entre as classes trabalhadora e burguesa, e explorando questões como a impunidade dos indivíduos proprietários de bens, que se põem acima das leis. E o segundo versa sobre a terrível a batalha de Stalingrado, exaltando em tom épico a cidade que resistiu à invasão nazista, promovendo uma inflexão nos rumos da guerra. Ambos abordam questões de natureza coletiva e expõem a intenção do poeta de compor um canto de grande amplitude, a abarcar temas tanto locais quanto internacionais.

No quarto e último capítulo, são analisados os poemas "Anúncio da rosa", "Mário de Andrade desce aos infernos" e "Canto ao homem do povo Charlie Chaplin". O primeiro ponto de contato entre os três consiste na discussão acerca do sentido da "rosa", que simboliza o canto poético ampliado, a reunir não apenas a voz do eu lírico como também a de outros seres e coisas. Opera-se com isso a constituição de um sujeito poético utópico, através do poema que se torna mais longo, tornando-se um lugar de enunciação coletiva. E demonstramos, por fim, que os dois últimos poemas do livro condensam a mensagem poética utópica de A Rosa do Povo.

Feita essa introdução aos capítulos, passamos a um breve panorama histórico e conceitual da utopia, que servirá de instrumento de analise dos poemas.

Segundo historiadores, o termo "utopia" surgiu como consequência dos relatos acerca da descoberta da América. Estes, ao descreverem um 'novo mundo' habitado por um 'novo homem', exerceram grande influência sobre a imaginação de intelectuais europeus que, insatisfeitos com as condições político-sociais de seu continente, começaram a escrever narrativas referentes a um mundo fantasioso e mais justo. Como se vê, o próprio termo utopia já nasce pela literatura, por meio de uma obra assumidamente ficcional, mas de teor reformador, inserida no debate de seu contexto histórico. 
Em 1516, foi publicada em latim a obra Utopia do inglês Thomas Morus, marco originário do termo. Nela é concebida uma ilha imaginária que, ao representar uma forma ideal de Estado, esboça a imagem de uma Inglaterra invertida, buscando com isso recusá-la criticamente. A topografia, a arquitetura e a estrutura político-econômica da ilha são descritas minuciosamente no livro. Seu protagonista, Rafael Hitlodeu, é um marinheiro que viajou pelos oceanos em companhia de Américo Vespúcio, até conhecer a "Ilha de Utopia", onde passou cinco anos, deixando-a apenas para narrar sua experiência ao resto do mundo. Hitlodeu entende que somente os "utopianos" alcançaram um estágio superior de felicidade. Entre os motivos desse bem-estar, menciona a inexistência da propriedade privada, com um regime de comunhão de bens entre os habitantes da ilha, e o controle rigoroso da economia e da vida social, que promoveria um desenvolvimento harmônico da sociedade e eliminaria a pobreza e o desejo de possuir. Na base do pensamento de Morus, está a crítica à propriedade privada e ao dinheiro enquanto valores sociais preponderantes. Segundo ele, enquanto não houvesse a abolição de uma noção patrimonialista nas sociedades, as riquezas não seriam distribuídas com justiça.

Analisando à distância, porém, não podemos deixar de frisar a carga ambígua do subtexto de Morus, um cristão convicto em plena era das reformas. Teria ele como ponto de partida uma visão reacionária oposta às transformações econômicas e sociais e valorizadora de estruturas tradicionais? Ou vemos antes a representação antecipatória de uma ideologia ainda embrionária, de uma sociedade sem classes e sem propriedade privada, baseada em leis justas e em instituições político-econômicas comprometidas com o bem-estar da coletividade? Utopia possui inúmeros sentidos e permite leituras variadas, sendo muitas as questões suscitadas pelo livro.

O sentido etimológico da palavra "utopia" designa um "não-lugar". Surge da junção dos elementos gregos ou (advérbio de negação) e topos (lugar), ou seja, refere-se a um "lugar que não existe". Ao mesmo tempo, designa o melhor lugar que poderia existir, porém de natureza irrealizável. É possível notar aqui a relação entre desejo e distância presente no imaginário 
ocidental, de modo que só o que não temos poderia ser considerado perfeito, remetendo à ideia cristã de que o 'paraíso' estaria situado fora da vida, numa espécie de 'além’ transcendental.

Uma das diferenças fundamentais entre a sociedade projetada por Morus e a sociedade comunista de Marx e Engels, por exemplo, consiste no grau de controle que o Estado exerceria sobre cada indivíduo. Na ilha de Utopia, haveria uma hierarquia bem delimitada, em que algumas famílias elegeriam anualmente magistrados que, por sua vez, escolheriam um príncipe com poderes vitalícios, só podendo ser destituído acaso se tornasse um tirano. Além disso, cada habitante da ilha exerceria uma atividade específica, e toda a estrutura social seria muito bem definida e estanque.

No caso de Marx e Engels, embora eles neguem por princípio a descrição da sociedade futura, parecem veicular em sua obra uma visão em filigrana de como ela seria. Uma sociedade em que os indivíduos poderiam escolher sua atividade de acordo com o próprio desejo, rompendo com a divisão do trabalho de caráter alienante imposta pelo "Capital", caracterizado como um poder estranho, externo e superior ao humano:

"Logo que o trabalho começa a ser distribuído, cada um passa a ter um campo de atividade exclusivo e determinado, que lhe é imposto e ao qual não pode escapar; o indivíduo é caçador, pescador, pastor ou crítico, e assim deve permanecer se não quiser perder seu meio de vida - ao passo que, na sociedade comunista, onde cada um não tem um campo de atividade exclusivo, mas pode aperfeiçoar-se em todos os ramos que lhe agradam, a sociedade regula a produção geral e me confere, assim, a possibilidade de hoje fazer isto, amanhã aquilo, de caçar pela manhã, pescar à tarde, à noite dedicar-me à criação de gado, criticar após o jantar, exatamente de acordo com a minha vontade, sem que eu jamais me torne caçador, pescador, pastor ou crítico. Esse fixar-se da atividade social, essa consolidação de nosso próprio produto num poder objetivo situado acima de nós, que foge ao nosso controle, que contraria nossas expectativas e aniquila nossas conjeturas, é um dos principais momentos no desenvolvimento histórico até aqui realizado." (MARX e ENGELS. 2007, p. 38) 
O comunismo entrevisto por Marx e Engels também apresenta um forte caráter utópico. Mas sua diferença em relação às utopias que o antecedem consistiria no fato de que a utopia marxista conseguiria detectar o 'ímpeto revolucionário latente' nas massas, criando com isso 'fissuras' na base estrutural das ordens vigentes, na medida em que o agente transformador da sociedade seria o povo, e não um 'messias' vindo 'do alto'.

Do século XVI até hoje, o termo criado por Morus alcançou enorme amplitude semântica, sendo objeto de extensa bibliografia teórica. A noção de utopia subentende uma análise crítica das aspirações humanas de transformação da realidade que possam proporcionar uma ideia de mundo ideal. Assim, o termo assumiu um sentido mais amplo do que o inaugurado pela obra de Morus, passando a ser utilizado tanto em relação a períodos que antecedem o século XVI, como a períodos recentes. Pode-se falar, por exemplo, em utopias gregas, como A República de Platão, na qual havia um projeto de legislação ideal. Em utopias medievais, como a "Cocanha", que se refere a uma ideia de abundância, lugar em que a pobreza seria superada por meio de banquetes, festas e danças, e não pela extinção da propriedade privada. Ou ainda em utopias do mundo moderno, que, especialmente nos séculos XIX e XX, ganharam novos sentidos e novas interpretações, inclusive com a tomada de consciência acerca da complexidade do fenômeno utópico, o que motivou um metadiscurso sobre as utopias, visando à redefinição do próprio conceito.

De qualquer modo, conforme a obra de Morus e outras abordagens modernas, o referido conceito está relacionado a uma noção característica da idade moderna de que o homem, em sua particularidade racional, é o agente criador e organizador de sua realidade. Tenta romper com uma noção mítica da antiguidade de que as sociedades humanas teriam sido oferecidas por deuses ou por qualquer outra ordem exterior ao mundo. Entretanto, parece haver um conteúdo 'mítico' na utopia, porque nela há algo suprarracional (ou surreal) que aponta para uma atemporalidade, para algo 'além', para o retorno de uma 'idade do ouro' ou para um 'paraíso perdido' com a 'queda'. A princípio, a ideia 'racional' do conceito de utopia romperia com a religião e com o mito, mas sempre há elementos que dificultam essa afirmação. Por meio da representação de uma sociedade 
ideal, o homem tenta afirmar a auto instituição da comunidade em que vive, como se esta fosse detentora de todos os poderes sobre si mesma e demonstrasse independência em relação a qualquer realidade pré-histórica, como também em relação ao mito e ao sagrado. Instala a vida social no seio da política, fazendo dos homens os supostos responsáveis pelos erros e acertos do bem estar humano.

Pode-se dizer que uma das marcas distintivas da modernidade, iniciada nos séculos XV e XVI, seria a crítica a antigos valores e instituições precedentes à afirmação plenamente racional do humano. O conceito de utopia parece reivindicar sempre ao indivíduo o direito de pensar, imaginar e criticar o social e o político. Segundo Octavio Paz, a idade moderna seria marcada por seu espírito crítico, demolidor de verdades preestabelecidas, e os vazios decorrentes dessa atuação seriam preenchidos por utopias, que, em determinadas situações, se converteriam em revoluções ou reformas sociais:

"La utopia es la otra cara de la crítica y solo una edad crítica puede ser inventora de utopias; el hueco dejado por las demoliciones del espíritu crítico lo ocupan casi siempre las construcciones utópicas. Las utopías son los sueños de la razón. Sueños activos que se transforman en revoluciones y reformas. La preeminencia de las utopías es otro rasgo original y característico de la Edad Moderna. Cada época se identifica con una visión del tiempo y en la nuestra la presencia constante de las utopías revolucionarias delata el lugar privilegiado que tiene el futuro para nosotros. El pasado no es mejor que el presente: la perfección no está atrás de nosotros sino adelante, no es un paraíso abandonado sino un territorio que debemos colonizar, una ciudad que hay que construir.” (PAZ. 1990, p. 33-34)

Paz sugere que as utopias seriam sonhos ativos da razão, que, por serem também revolucionários, mostrariam o 'lugar privilegiado' do ‘futuro' no imaginário moderno, que exigiria sempre a busca pela construção da 'cidade ideal'. Essa visão linear da história teria como marco de origem o cristianismo, que opôs ao tempo cíclico do pensamento mítico uma ideia de tempo sucessivo, pressupondo um princípio e um fim, da queda de Adão e Eva ao juízo final. Entretanto, o tempo histórico cristão teria como pressuposto, também, um tempo sagrado, o da "eternidade". Por 
isso a descida de Cristo à terra marcaria um momento único de 'redenção', ou seja, a fusão do tempo da 'eternidade' com a temporalidade da história.

Nisso estaria o caráter messiânico de certas utopias que será explorado neste estudo. Segundo Michael Löwy (1990), o 'messianismo' conteria em si duas tendências contraditórias: a de restauração de uma harmonia edênica, e a de aspiração a um futuro radicalmente novo, em que os elementos do passado estivessem redivivos sob a transformação do sonho da utopia. De acordo com Gershom Scholem, citado por Löwy, a visão messiânica concebe a transição do presente histórico para um 'futuro messiânico', por meio de uma 'irrupção catastrófica', ou seja, por uma espécie de 'intervenção' exterior à história, contrariando uma ideia de 'progresso infinito', tributária ao Iluminismo:

"A Bíblia e os escritores apocalípticos jamais vislumbraram um progresso da história que conduzisse à redenção (...) A redenção é antes o surgimento de uma transcendência acima da história, uma intervenção que faz a história se dissipar e desmoronar, a projeção de um jato de luz a partir de uma fonte exterior à história.” (LÖWY. 1990, p. 135)

Outro modo de se compreender o utópico consiste na ideia de uma "utopia alquimista", cuja finalidade é a modificação radical da condição humana e do mundo mediante um processo simbolizado pela transmutação dos metais vulgares em ouro. De acordo com Ernst Bloch, a partir do século XV forma-se a fraternidade Rosa-Cruz, que vai alçar a alquimia ancestral a um estágio superior, conferindo-lhe um caráter humanitário e estabelecendo um elo entre sua faceta enigmática e o Iluminismo. Bloch entende que a própria noção de "Esclarecimento" representa inicialmente um conceito da alquimia: "o próprio páthos em relação à luz, como 'nascimento', como 'processo' progressivo da luz (do ouro), é originário da alquimia” (BLOCH. 2006a, p. 189-190). As experiências alquímicas em substâncias minerais e vegetais se caracterizam como "uma ascensão de baixo no sentido do melhor" (idem, p. 192), compreendendo a elaboração de uma "pedra filosofal' ou 'pedra de ouro', cujo toque viria a provocar alteração no modo de ser e 
rejuvenescimento dos corpos, sendo uma espécie de "mitologia de libertação" das coisas e dos seres.

Sendo assim, leremos A Rosa do Povo intercalando o aspecto mais racional e crítico da utopia, o que a assemelha mais à ideologia, ao seu aspecto mais intuitivo e simbólico, o que aproxima o utópico do mito e da alquimia. Entendemos que essa conjunção no livro, de camadas tanto ideológicas quanto simbólicas, está condensada na imagem da "rosa aurilavrada", a qual iremos analisar detidamente no quarto capítulo. 


\section{Enunciação da utopia do poema}

\subsection{Impulso afirmativo: "Consideração do poema"}

Um movimento emblemático de A Rosa do Povo consiste na caminhada pela cidade de um sujeito poético que se vai apossando das ruas, atravessado por um desejo de comunhão com o outro, que contraria a ideia de interdição, de "país bloqueado". Esse impulso associa-se não apenas à ideia de constituição do sujeito, como também à projeção de uma utopia socialista. Essa "flânerie" de Drummond busca furtar-se ao olhar medusante, reificador das mercadorias, como se lê nestes versos de "A flor e a náusea": "Melancolias, mercadorias, espreitam-me. Devo seguir até o enjôo? Posso, sem armas, revoltar-me?". Dentro desse movimento projetivo, de se lançar adiante, é retomado em "Consideração do poema" um lugar-comum alegórico do poeta enquanto marinheiro que inicia uma travessia marítima:

\section{“CONSIDERAÇÃO DO POEMA}

Não rimarei a palavra sono

com a incorrespondente palavra outono.

Rimarei com a palavra carne

ou qualquer outra, que todas me convém.

5 As palavras não nascem amarradas, elas saltam, se beijam, se dissolvem, no céu livre por vezes um desenho, são puras, largas, autênticas, indevassáveis.

Uma pedra no meio do caminho

10 ou apenas um rastro, não importa.

Estes poetas são meus. De todo o orgulho, de toda a precisão se incorporaram ao fatal meu lado esquerdo. Furto a Vinicius sua mais límpida elegia. Bebo em Murilo.

15 Que Neruda me dê sua gravata 
chamejante. Me perco em Apollinaire. Adeus, Maiakovski.

São todos meus irmãos, não são jornais

nem deslizar de lancha entre camélias:

é toda a minha vida que joguei.

20 Estes poemas são meus. É minha terra

e é ainda mais do que ela. É qualquer homem

ao meio-dia em qualquer praça. É a lanterna

em qualquer estalagem, se ainda as há.

— Há mortos? há mercados? há doenças?

25 É tudo meu. Ser explosivo, sem fronteiras,

por que falsa mesquinhez me rasgaria?

Que se depositem os beijos na face branca, nas principiantes rugas.

O beijo ainda é um sinal, perdido embora,

da ausência de comércio,

30 boiando em tempos sujos.

Poeta do finito e da matéria,

cantor sem piedade, sim, sem frágeis lágrimas,

boca tão seca, mas ardor tão casto.

Dar tudo pela presença dos longínquos,

35 sentir que há ecos, poucos, mas cristal,

não rocha apenas, peixes circulando

sob o navio que leva esta mensagem,

e aves de bico longo conferindo

sua derrota, e dois ou três faróis,

40 últimos! esperança do mar negro.

Essa viagem é mortal, e começá-la.

Saber que há tudo. E mover-se em meio

a milhões e milhões de formas raras,

secretas, duras. Eis aí meu canto.

Ele é tão baixo que sequer o escuta

ouvido rente ao chão. Mas é tão alto

que as pedras o absorvem. Está na mesa

aberta em livros, cartas e remédios.

$\mathrm{Na}$ parede infiltrou-se. $\mathrm{O}$ bonde, a rua,

o uniforme de colégio se transformam, 
são ondas de carinho te envolvendo.

Como fugir ao mínimo objeto

ou recusar-se ao grande? Os temas passam,

eu sei que passarão, mas tu resistes,

55

e cresces como fogo, como casa,

como orvalho entre dedos,

na grama, que repousam.

Já agora te sigo a toda parte,

e te desejo e te perco, estou completo,

60

me destino, me faço tão sublime,

tão natural e cheio de segredos,

tão firme, tão fiel... Tal uma lâmina,

o povo, meu poema, te atravessa."

Nesses versos é enunciada a busca pela forma cristalina, por algo que não se restrinja à opacidade da rocha, metaforizando a própria busca por uma espécie de transformação do indivíduo e enunciando o processo que se dará no percurso do livro. Segundo João Adolfo Hansen, a alegoria do escritor navegante teria origem na poesia greco-latina, sendo depois retomada por Dante e por muitos outros autores modernos, como Mallarmé. A travessia pode significar tanto o destino pessoal como o ato de escrever um poema ou um livro:

"É lugar-comum muito usual o da travessia por mar, ilustrado pela ode de Horácio, também significando o destino pessoal ou o ato mesmo de compor um poema: 'vela dare', 'soltar as velas', assim Virgílio se refere à invenção poética nas Geórgicas, II, 41. Como explica Curtius, o poeta torna-se marinheiro e o barco alegoriza seu espírito ou obra. Como a viagem é perigosa se for dirigida por marinheiro inexperiente, rudis nauta, é preciso conduzir bem o barco entre escolhos para alcançar bom porto. (...) Esse lugar-comum greco latino é retomado em vários momentos por Dante e outros autores medievais, chegando à modernidade, como no belíssimo 'Salut', poema de abertura do livro de sonetos de Mallarmé" ${ }^{4}$ (HANSEN. 2006, p. 32).

\footnotetext{
${ }^{4}$ Saudação: "Nada, esta espuma, puro verso / A aludir apenas à taça; / Tal ao longe se afoga um bando / de sereias, tanta ao invés. // Navegamos, ó meus diversos / Amigos, eu já bem à popa / Vós à proa em fausto que corta / a vaga de raios e
} 
De modo semelhante ao que se lê no soneto "Salut" de Mallarmé, "Consideração do poema" é simultaneamente um brinde literário a poetas de sua geração e metadiscurso do ofício poético, como também enunciado de uma navegação. Ao retomar esse lugar-comum, enquanto ritual de entrada na escrita, ${ }^{5}$ Drummond parece indicar não só a intenção de diálogo com a tradição literária, mas também o intuito de renová-la por meio da incorporação em sua poesia do tempo histórico em que vive.

Vale notar a recorrência obsessiva da palavra rua na obra de 45 , seja como referência à cidade (" $O$ bonde, a rua"), seja enquanto metáfora do poema que ser quer participativo (" $A$ rua infinita / vai além do mar. / Quero caminhar"), seja ainda como rememoração do passado (“Nos áureos tempos / a rua era tanta."), mas expressando sempre a projeção de um desejo de mobilidade e de troca com as pessoas, por meio da incorporação das suas diferentes vozes, em poemas cada vez mais longos e com maior variedade de ritmos. ${ }^{6}$ Em nossa leitura de "Morte do leiteiro" no terceiro capítulo, por exemplo, é demonstrada a consubstanciação entre poema e mundo na rua, através da imagem da fusão do sangue e do leite em decorrência da morte. Outro exemplo dessa busca constante por contato humano pode ser lido no título da segunda seção de Confissões de Minas (1944), "Na rua, com os homens", na qual são reunidos os textos que versam sobre autores contemporâneos, e sublinhada a necessidade de diálogo tanto com escritores nacionais como estrangeiros.

Em A Rosa do Povo é recorrente a imagem do "navio", ora representando o próprio poema ou o livro como um todo, conforme estes versos de "Mas viveremos": "Ele viaja sempre, esse navio, / essa rosa, esse canto, essa palavra"; ora remetendo à ideia de casa, acolhedora e imóvel,

invernos; // Tão bela embriaguez me impele / sem sequer temer o vaivém / A fazer de pé este brinde // Recife, solidão, estrela / A não importa o que foi digno / Da branca angústia desta tela." Stéphane Mallarmé, trad. José Augusto Seabra. Lisboa: Assírio \& Alvim, 2004.

${ }^{5}$ É interessante notar que Fernando Pessoa também faz esse ritual ao publicar o seu primeiro texto literário, em 1915, justamente intitulado "O marinheiro".

"A palavra "rua", no singular ou plural, é repetida 48 vezes ao longo da obra, podendo ser lida nos poemas "Consideração do poema", "Procura da poesia", "A flor e a náusea", "Carrego Comigo", "O medo", "Nosso tempo", "Passagem da noite", "Uma hora e mais outra", "Nos áureos tempos", "O mito", "O caso do vestido", "O elefante", "Morte do leiteiro", "Morte no avião", "Interpretação de dezembro", "Rua da madrugada", "Idade madura", "Versos à boca da noite", "América", "Carta a Stalingrado", "Telegrama de Moscou”, "Mas viveremos”, "Visão 1944”, "Com o russo em Berlim", "Onde há pouco falávamos", "Mário de Andrade desce aos Infernos" e "Canto ao homem do povo Charlie Chaplin", ou seja, em 28 dos 55 poemas do livro. 
mas que, por sua natureza de canto, navega: "Todas as brisas da saudade balançam a casa, / empurram a casa, navio de São Paulo no céu nacional" ("Mário de Andrade desce aos infernos"). ${ }^{7}$ Já a imagem de 'pedaços de navios', contida em "Visão 1944”, refere-se metalinguisticamente a 'poemas partidos' ou 'corpos repartidos', como também, do ponto de vista histórico, à violência em escala global dos conflitos navais durante a Segunda Guerra.

O sujeito lírico de "Consideração do poema” parece indicar que, por meio da viagem poética a ser empreendida, o poema se converteria num lugar de encontro de diferentes vozes, poéticas, tempos, línguas, nacionalidades, ou seja, num espaço de fraternização realizado em seu próprio corpo de palavras. Ao mesmo tempo, seria um espaço possuído exclusivamente pelo poeta, reforçando a ambiguidade da composição, oscilante entre o fazer do todo um objeto de pertencimento próprio, e o desejo de entender-se parte do todo, possuído por este, leitura que pode ser complementada pelo seguinte trecho do ensaio "Inquietudes na poesia de Drummond", de Antonio Candido: "O sentimento de insuficiência do eu, entregue a si mesmo, leva-o a querer completar-se pela adesão ao próximo, substituindo os problemas pessoais pelos problemas de todos" (CANDIDO. 2004, p. 79). Esse movimento é expresso pela contraposição dos pronomes possessivos "meus", “minha", "meu”, que transmitem uma noção de posse e de individualidade, ao adjetivo "qualquer", que confere aos substantivos um caráter de indefinição:

\footnotetext{
"Uma pedra no meio do caminho ou apenas um rastro, não importa.

Estes poetas são meus. De todo o orgulho, de toda a precisão se incorporaram ao fatal meu lado esquerdo. Furto a Vinicius sua mais límpida elegia. Bebo em Murilo.

Que Neruda me dê sua gravata chamejante. Me perco em Apollinaire. Adeus, Maiakovski.

São todos meus irmãos, não são jornais
}

\footnotetext{
${ }^{7}$ Lê-se "navio" ou "navios" em dez poemas do livro, a saber: "Consideração do poema", "Fragilidade”, Edifício São Borja", "Consolo na praia", "Notícias", “América", "Mas viveremos", "Visão 1944”, "Mário de Andrade desce aos infernos", "Canto ao homem do povo Charlie Chaplin".
} 
nem deslizar de lancha entre camélias:

é toda a minha vida que joguei.

Estes poemas são meus. É minha terra

e é ainda mais do que ela. É qualquer homem

ao meio-dia em qualquer praça. É a lanterna

em qualquer estalagem, se ainda as há.

- Há mortos? há mercados? há doenças?

É tudo meu. Ser explosivo, sem fronteiras,

por que falsa mesquinhez me rasgaria?"

Ao referir-se ao poema "No meio do caminho", de Alguma poesia (1930), "Uma pedra no meio do caminho, / ou apenas um rastro, não importa", o intertexto evoca a imagem da pedra, mas amainando a marca individualizante da autoria, o que é ressaltado pelo paralelismo entre os versos "Estes poetas são meus" da segunda estrofe, e "Estes poemas são meus", da terceira, a sugerir uma relação aberta e permeável entre poetas e poemas.

Ao identificar o eu lírico e o mundo, o poema se tornaria íntegro, público, participante em sua plena maturidade. Ele seria "qualquer homem / ao meio-dia em qualquer praça". É como se a composição lírica realizasse a façanha de fazer da figura simbólica do poeta um sujeito ativo. Os versos "É tudo meu. Ser explosivo, sem fronteiras, / por que falsa mesquinhez me rasgaria?", criticariam uma postura que não fosse de solidariedade ilimitada, como, por exemplo, a restrição a projetos nacionalistas.

Mas eis o foco da tensão em "Consideração do poema": o impulso do poema aparenta ser a sua própria existência, independentemente de qualquer imposição de fora. Ele não se submeterá ao mundo, mas o mundo lhe servirá. O mundo seria 'matéria' da poesia, e nesta é que ele se realizaria enquanto 'totalidade'. Daí a utopia do poema: valer-se por si mesmo, já que o mundo estaria nele. Não valeria a obra referencial panfletária, mas o seu avesso: a composição lírica é um objeto estético, tudo a acaricia, sendo este o movimento centrípeto da poética anunciada, "O bonde, a rua, 
/ o uniforme de colégio se transformam, / são ondas de carinho te envolvendo". O poema se elabora como um filtro, corpo central e centralizante, que operaria a transformação do homem e do mundo.

O poeta e crítico francês Henri Meschonnic elaborou conceitualmente duas espécies de utopia do poema: uma ativa, relacionada à afirmação da existência do poema, que seria o lugar em que a poesia se elabora; e outra passiva, referindo-se à impossibilidade de o poema existir no mundo, já que a poesia, sendo algo inacessível e superior ao poema, só poderia ser evocada por ele. Como instrumento para análise de "Consideração do poema”, detenho-me à primeira conceituação.

Para Meschonnic, a utopia ativa do poema se caracterizaria simultaneamente sob três aspectos. Em primeiro lugar, como crítica a um sistema de discurso sedimentado na linguagem, ou seja, como adoção de um novo ritmo que rompesse tanto com uma noção formal de poesia vinculada à métrica, quanto com uma noção mística de fusão do poema com o cosmos ou com o 'sentimento das coisas'. Em segundo lugar, como reinvenção ilimitada da poesia. E em terceiro lugar, como atividade ética e política que compromete o sujeito, na medida em que o poema não seria somente uma arte da linguagem no sentido estético, pressupondo também uma ética poética, que ora o constitui como uma função e uma atividade da linguagem, ora como uma ideia da interação "linguagem-poema-sujeito-ética-política". A articulação desses três aspectos da "utopia do poema" representariam uma única utopia: a da invenção de um “sujeito utópico do poema":

"se pode chamar poema à transformação de uma forma de vida por uma forma de linguagem e, recíproca e inseparavelmente, é também a transformação de uma forma de linguagem por uma forma de vida, esta operação só pode ser a actividade de um sujeito específico, ao qual se deve chamar sujeito do poema." (MESCHONNIC. 2009, p. 211)

Segundo o crítico francês, este sujeito do poema seria utópico, por não ter lugar nem espaço na noção estereotipada de sujeito. O estereótipo reuniria em si diversos tipos de indivíduos, sem se preocupar em distinguir suas diferenças. Não consideraria a ideia de individuação do sujeito do poema, o qual, na medida mesma em que escreve um poema, estaria se inserindo na modernidade 
por meio de um gesto simultaneamente corporal, lingüístico, ético e político, transformando-se ele mesmo, no corpo do texto, num novo indivíduo, pondo em crise a noção estereotipada do sujeito da contemporaneidade. A essa intenção utópica de fundir o homem ao poema, para que neste pudesse ser alcançada uma espécie de totalidade, através da criação de um outro mundo que recusasse criticamente a realidade como ela é ou como é representada, Meschonnic atribui um caráter messiânico:

“A utopia é, portanto, uma ficção no sentido em que enuncia algo que não tem lugar. Mas ela não é de todo um discurso sobre um impossível. É precisamente o contrário. Neste sentido, se não possui o espaço, ela possui o tempo. Trata-se de uma construção que supõe e, até mesmo, impõe - um futuro. A utopia é missionária, senão mesmo messiânica. Porque contém o significado imperioso da sua própria necessidade - o rosto construtivo da sua recusa do mundo tal como ele é e tal como ele se diz. É nisto que a utopia e a crítica são uma única e a mesma coisa." (idem, ibidem)

Assim, pergunta-se se tanto "Consideração do poema" quanto o título A Rosa do Povo, na medida em que imaginam o poema ou o livro como um objeto utópico - que, no processo de confecção da obra, se eleva à qualidade de uma "rosa aurilavrada" -, contendo a esperança de promover a modificação do sujeito lírico e do mundo, não indicariam uma concepção utópica acerca da atuação da poesia? Não estaria aqui o caminho de leitura que evidenciasse o caráter utópico da obra? No ensaio já mencionado, Antonio Candido chamou atenção para a função redentora de uma fase da poesia drummondiana, acentuada pelo contexto histórico em que foi produzida:

"Essa função redentora da poesia, associada a uma concepção socialista, ocorre em sua obra a partir de 1935 e avulta a partir de 1942, como participação e empenho político. Era o tempo da luta contra o fascismo, da guerra de Espanha e, a seguir, da Guerra Mundial - conjunto de circunstâncias que favorecem em todo o mundo o incremento da literatura participante." (CANDIDO. 2004, p. 79) 
Como já se disse, "Consideração do poema” dá início à fixação dos termos de uma poética que permeará grande parte dos poemas de A Rosa do Povo, partindo da definição de um eu lírico individualizado e conquistando-lhe aspectos cada vez mais socializantes, o que ocorrerá simultaneamente a um processo simbólico de transmutação da palavra. Parece existir a confiança de que o verbo criador poderia libertar as matérias embrenhadas num 'caos', isto é, que poderia despertar as palavras "ainda úmidas e impregnadas de sono" ("Procura da poesia"), retirando-as do refúgio da noite. $\mathrm{O}$ mesmo gesto de libertação parece estar contido nestes versos de "Consideração do poema", em que a palavra, enquanto matéria prima do ofício poético, se mostraria autônoma e potente se utilizada a despeito de convenções limitadoras:

\footnotetext{
"Não rimarei a palavra sono

com a incorrespondente palavra outono.

Rimarei com a palavra carne

ou qualquer outra, que todas me convém.

As palavras não nascem amarradas,

elas saltam, se beijam, se dissolvem,

no céu livre por vezes um desenho,

são puras, largas, autênticas, indevassáveis."
}

Essa 'autonomia' faz com que as palavras se misturem e se dissolvam entre si, como substâncias químicas no corpo do poema. Pode-se desconfiar, assim, da afirmação do eu lírico de que haveria uma suposta incompatibilidade entre as palavras sono e outono, mesmo porque a recusa de aproximação entre elas seria ao mesmo tempo refutada pela rima realizada no poema, isto é, o discurso do sujeito parece ter a intenção de provocar uma ruptura no lugar amarrado em que o fazer poético se encontra, explicitando as inúmeras possibilidades de se compor poemas mediante o uso desimpedido de sua matéria prima. A recusa da rima, na rima, e do lugar comum das imagens sono e outono, e simultaneamente fazer da rima meio de recusa, atesta a envergadura irônica do poema, 
que quebra com procedimentos formais estabilizados pela convenção, de modo que sono e outono rimariam não apenas sonoramente, mas também em seus significados.

Nisto se sê um princípio de renovação constante da poesia por meio da desintegração, da intervenção, da mescla, do processo modificador de sua matéria-prima: "As palavras não nascem amarradas, / elas saltam, se beijam, se dissolvem, / no céu livre por vezes um desenho," como se esse movimento se dirigisse, inclusive, contra a ideia de um céu congelado que representasse um destino histórico fixo, inexorável, que retirasse ao humano a liberdade de agir para construção de seu próprio caminho.

Em “Consideração do poema” são expostos ainda os princípios de uma poética que busca a confluência entre registros líricos contrastantes, se dirigindo tanto para o 'elevado' como para o 'baixo', buscando a conjugação entre as soluções "hierática" e "demótica”, o que, para Sérgio Buarque de Holanda, decorre da aguda consciência de Drummond acerca da impossibilidade de uma depuração extrema da poesia, que desta eliminasse todo o prosaísmo: "Na sua poesia, o prosaico não é negação, é antes condição do poético (...) é um modo, em outras palavras, de intensificar-se o poético pela própria força do contraste” (BUARQUE DE HOLANDA. 1996, p. 502). Ao mesmo tempo em que se diz um "Poeta do finito e da matéria", o que poderia indicar a noção de uma poesia que aborda exclusivamente assuntos terrenos, aponta para a busca da "presença dos longínquos", para algo elevado como as formas raras e secretas:

"Poeta do finito e da matéria cantor sem piedade, sim, sem frágeis lágrimas, boca tão seca, mas ardor tão casto.

Dar tudo pela presença dos longínquos, sentir que há ecos, poucos, mas cristal, não rocha apenas, peixes circulando (...)

Saber que há tudo. E mover-se em meio a milhões e milhões de formas raras, secretas, duras. Eis aí meu canto.” 
Nos versos "sentir que há ecos, poucos, mas cristal, / não rocha apenas", a imagem diáfana do cristal corresponde a uma forma condensada dos ecos, metaforizando algo vago, sem substância, mas, por ser cristal, indica também matéria de pureza e transparência. Em contraposição ao cristalino, há a imagem da rocha, matéria opaca, composta de substâncias minerais e orgânicas, massa extremamente sólida e estabelecida no solo. Já os versos "Saber que há tudo (...) Eis aí meu canto" indicam a amplitude da poética anunciada, abrangendo tanto as questões materiais, quanto as imateriais. ${ }^{8}$

Exemplo dessa conjugação entre elementos espirituais e mundanos pode ser lida na tese de doutoramento intitulada "O erotismo nos poemas inéditos de Carlos Drummond de Andrade" (1992), de Maria Lucia do Pazo Ferreira, que, ao longo de sua pesquisa, passou a conviver com Drummond e foi, em certa medida, 'coorientada' por ele. Maria Lucia menciona ter sido o poeta quem a conduziu ao estudo de assuntos de natureza mística, como a mitologia celta, a heresia cátara, o agnosticismo: "Foi ainda você [Carlos] que me revelou o viés do misticismo. Eu apenas segui por onde você me conduziu. Esta é uma Tese sua, escrita por mim, com feitio de homenagem" (PAZO FERREIRA. 1992, p. 6). Segundo ela, o argumento de sua tese "foi demonstrar que Drummond, um agnóstico racional por excelência, atravessou com recursos técnicos a linguagem mística, descartando a pornografia a fim de introduzir o erotismo, enquanto forma de santidade, no espaço estético" (idem, p. 13). Segundo Georges Bataille, haveria um "paralelo introduzido pela

\footnotetext{
${ }^{8}$ Para mostrar a 'opção' de Drummond pela associação entre os registros 'baixo' e 'elevado', é interessante ler a nota de Confissões de Minas (1944), intitulada "Pontuação e poesia". Nela o poeta fala o que a falta de pontuação regular na poesia de Mallarmé e de Apollinaire causa na sua sensibilidade de leitor. Quanto ao primeiro, a inexistência de pontuação ressalta a sensação de transparência, de evasão do plano material, de modo semelhante à imagem do quarto na poesia de Manuel Bandeira. Já em Appolinaire, em vez de uma impressão de "flutuação do verso na atmosfera", sugere a sensação de arrastamento na terra, de impossibilidade de libertação da prisão humana. De acordo com o poeta mineiro, somente a pontuação regular proporcionaria uma visão panorâmica sobre toda a amplitude do terreno poético, impedindo o predomínio de algum acidente específico: "Um e outro efeito não são necessariamente produzidos pela falta de sinais de pontuação, mas antes salientados por esse artifício, que confirma em Mallarmé a misteriosa diafaneidade, a libertação de todo compromisso terrestre, e em Apollinaire a indeterminação entre o poeta e o mundo. $E$ de um modo geral, poder-se-á dizer que a pontuação regular, iluminando igualmente todos os ângulos da superfície poética, impede que se destaque algum de seus acidentes mais característicos" (DRUMMOND DE ANDRADE. 2011a, p. 195). Drummond utiliza pontuação regular em quase toda sua obra, empregando-a em todos os poemas de $A$ Rosa do Povo. Assim, a reflexão acima parece confirmar essa busca do autor por uma poesia totalizante, que englobe o imaterial e o terreno, por meio de uma caracterização ampla e simultânea dos 'acidentes da superfície poética'.
} 
linguagem dos místicos entre a experiência do amor divino e a da sexualidade, [sublinhando] a capacidade da união sexual de simbolizar uma união superior" (BATAILLE. 2004, p. 351).

Além disso, em entrevista concedida a Maria Lucia em junho de 1984, o poeta responde que, entre as influências da sua poesia, desde que começara a escrever, há também as não literárias, dando, como exemplo, as essências de perfume das antigas farmácias:

“Olha, essas influências são inúmeras, e não são simplesmente literárias, são de toda natureza. (...) As farmácias antigas tinham um cheiro especial, devido à manipulação de certas essências que exalavam um perfume muito agradável. Esse cheiro vinha acompanhando os almanaques que a gente ganhava; almanaques publicados pelos laboratórios, a Bayer e o Elixir Capivarol faziam isso.” (PAZO FERREIRA. 1992, p. 330)

A partir dessa declaração de Drummond - e da presença de elementos da simbologia alquímica em sua poesia, como iremos demonstrar neste estudo -, podemos questionar a validade da afirmação de seu biógrafo José Maria Cançado, no sentido de que o poeta não teria extraído nenhuma inspiração literária, nenhum motivo poético de sua graduação em farmácia, da qual sempre foi aluno assíduo:

"Não há uma única menção do poeta ao que o mergulho na química dos elementos, na história natural, na bromatologia, no laboratório, e nas disciplinas do curso de um modo geral, teria lhe despertado. Parece que não despertou nada. Drummond não credita nenhum motivo poético, nenhuma idéia, nenhuma intuição literária, à sua passagem pelo curso de farmácia, embora ele fosse muito assíduo às aulas, garante a ex-colega Erínia Costa." (CANÇADO. 1993, p. 106)

Ao contrário do entendimento acima, é possível imaginar que Drummond já sentisse atração por assuntos ligados à química antes mesmo de ingressar na faculdade, assuntos esses que, como ele mesmo disse na entrevista mencionada, teriam influenciado sua poesia. Nesse sentido, vale destacar 
que a alquimia tradicional não só deu origem à química moderna, como também influenciou inúmeros autores da revolução científica. ${ }^{9}$

Segundo Mircea Eliade, Isaac Newton “terá explorado 'todas as obras da antiga alquimia, como jamais havia sido feito antes, ou depois"” (ELIADE. 2000, p. 24), sendo, "extremamente significativo que o fundador da física mecânica moderna nunca tenha rejeitado a teologia da revelação primordial oculta, nem o princípio da transmutação, o próprio fundamento da alquimia" (idem, p. 25). Entretanto, Eliade ressalta que o físico inglês sempre evitou expor os segredos da alquimia, pois acreditava que estes teriam sido ensinados somente para alguns 'eleitos'. Para Newton, tal conhecimento se teria perdido, estando apenas parcialmente recuperado e incorporado nos mitos e fábulas. Eliade sublinha a importância do segredo na transmissão das doutrinas e técnicas alquímicas:

“A incompreensibilidade deliberada dos textos alquímicos para o não iniciado tornar-se-á quase um lugar comum na literatura ocidental após o Renascimento. Um autor citado pelo Rosarium philosophorum declara: 'Só aquele que sabe como fazer a pedra filosofal compreende as palavras que a ela dizem respeito'. E o Rosarium adverte o leitor de que estas questões devem ser transmitidas de um 'modo místico', da mesma forma que a poesia emprega as fábulas e as parábolas. Numa palavra, somos confrontados com uma 'linguagem secreta'. De acordo com alguns autores, haveria mesmo um 'juramento de não divulgar o conteúdo dos livros"”. (idem, p. 8-9)

Talvez seguindo esses princípios, Carlos Drummond tenha evitado comentar abertamente como por exemplo em correspondências, entrevistas, ensaios ou crônicas - acerca da presença da simbologia alquímica em sua obra poética, expondo-a mais por meio de quadros simbólicos,

\footnotetext{
${ }^{9}$ É interessante notar ainda que, ao longo da história, inúmeros autores se inspiraram na linguagem da alquimia para a criação de suas obras. E um exemplo relevante é o caso de Dante, que, segundo Hilário Franco Júnior, teria escrito toda a Divina Comédia seguindo os preceitos alquímicos para a confecção de uma 'Grande Obra', como se lê no ensaio "Em busca da Idade do Ouro: o papel da alquimia em Dante Alighieri": " $a$ Commedia revela-se uma Grande Obra, isto é, a concretização no plano do imaginário da transmutação da matéria e do homem desejada pelos alquimistas" (FRANCO JR. 1896/87, p. 65). Franco Júnior acrescenta que, numa ocasião em que Dante, por motivos políticos, teve de se associar a uma corporação profissional, vinculou-se justamente à corporação dos médicos e farmacêuticos, causando estranheza na sociedade da época, que não entendia o porquê de um escritor renomado ter tomado tal decisão: "opção estranha essa para um literato porém compreensível para alguém com interesse pela Alquimia” (idem, p. 66).
} 
alegorias, ambiguidades, a fim de exigir do leitor trabalho e esforço intelectuais para alcançar o pensamento cifrado contido nos textos, proporcionando-lhes com isso a possibilidade de 'elevação'.

Essa proposta estética do leitor como um 'decifrador' aplicado e atento do 'segredo' era também o centro da proposta poética do Simbolismo, no final do século XIX. E não podemos negar a influência dessa tradição, muito forte na França e também no Brasil, na obra poética drummondiana. Aliás, na referida entrevista a Maria Lucia do Pazo Ferreira, Drummond reconhece que a poesia simbolista foi uma de suas grandes influências: "através de meu irmão, fui adquirindo um conhecimento maior dos Simbolistas franceses, Verlaine, Mallarmé, Rimbaud, etc... e me apaixonei por eles. No Brasil esses poetas refletiam-se em Álvaro Moreyra, em Eduardo Guimaraens (...) e no nosso velho Alphonsus, espécie de ídolo da mocidade de meu tempo" (PAZO FERREIRA. 1992, p. 331). Um livro de Drummond, que explora de maneira mais explícita a simbologia alquímica, é Fazendeiro do Ar (1955), como se pode ler no poema "Retorno":

"Meu ser em mim palpita como fora do chumbo da atmosfera constritora. Meu ser palpita em mim tal qual se fôra a mesma hora de abril, tornada agora.

Que face antiga já se não descora lendo a efígie do corvo na da aurora? Que aura mansa e feliz dança e redoura meu existir, de morte imorredoura?

Sou eu nos meus vinte anos de lavoura de sucos agressivos, que elabora uma alquimia severa, a cada hora.

Sou eu ardendo em mim, sou eu embora não me conheça mais na minha flora que, fauna, me devora quanto é pura." 
Além de dizer que o seu ofício poético consiste na elaboração de uma "alquimia severa", refere-se na primeira estrofe ao "chumbo da atmosfera constritora", elemento químico que representa, no pensamento alquímico, o estágio mais inferior da matéria, a qual atingiria qualidade de maior pureza e elevação por meio dos experimentos em laboratório, que geralmente se iniciam pela dissolução. Também há a referência ao mês de abril, que, no hemisfério sul, corresponde ao início do outono, época em que se dá o início dos trabalhos alquímicos, simbolizado pela "efígie do corvo" - outono que é, justamente, a estação do ano referida em "Consideração do poema".

A noção de uma 'utopia alquimista' em A Rosa do Povo pode ser definida como metáfora de um trabalho que visa à catarse das palavras, concomitantemente com a do sujeito poético e do leitor, buscando a 'síntese do ouro', isto é, a composição da "rosa aurilavrada". Esta, além de metaforizar uma espécie de totalidade do poema e do sujeito, simboliza um instrumento cujo contato seria capaz de modificar o modo de ser dos indivíduos e das coisas, rejuvenescendo-os.

Em “Consideração do poema”, é lida a enunciação do poema ou da obra que se formará no processo do livro, crescendo como "casa", absorvendo as experiências cotidianas que, juntamente com as experiências memorialísticas e históricas, serão submetidas metaforicamente a processos de dissolução, depuração, calcinação, para enfim transmitir o que se elaborou artisticamente nessa mistura:

"Ele é tão baixo que sequer o escuta ouvido rente ao chão. Mas é tão alto que as pedras o absorvem. Está na mesa aberta em livros, cartas e remédios. Na parede infiltrou-se. O bonde, a rua, o uniforme de colégio se transformam, são ondas de carinho te envolvendo.

Como fugir ao mínimo objeto ou recusar-se ao grande? Os temas passam, eu sei que passarão, mas tu resistes, 
e cresces como fogo, como casa,

como orvalho entre dedos,

na grama, que repousam."

Note-se, aliás, que a imagem do orvalho simboliza, na alquimia, a conjunção das águas terrestres e celestes, sendo o sinal do início de um processo regeneração, um princípio da luz que emergirá das trevas, o que se coaduna não apenas com a amplitude da poética enunciada, que quer unir o 'baixo' e o 'elevado', como também com a natureza processual que atribuímos ao livro. ${ }^{10}$

O canto traz ainda a ideia de possessão das coisas exteriores, de envolvimento erótico. Nele passa a existir uma dupla referência ao cantar: o poema é quem canta e para quem se canta. O ofício poético é como um constante 'retorno' sobre si mesmo, enquanto matéria frágil, matéria de morte, para extrair de si o cristal, pela lavoura da voz, das palavras, e então ofertar este produto ao mundo, ao leitor. Esse movimento ensimesmado se dá, por exemplo, pela mudança de utilização do pronome "ele", que designa certo distanciamento por não colocar o outro em interpelação, para o pronome "tu" ("são ondas de carinho te envolvendo"), que pode referir-se a uma ou a várias instâncias ao mesmo tempo, dirigindo-se não só à pessoa fictícia constituída no poema, como também ao leitor, a quem é destinada a enunciação.

Assim, o uso da metalinguagem parece indicar que, neste início do livro, em vez de ir para fora, o mergulho do eu lírico é cada vez mais para dentro da sua interioridade, na medida em que tudo se transforma, de fora para dentro, e de dentro para dentro, num movimento de possessão, de força centrípeta, buscando cada vez mais a intimidade do "tu", que pode ser simultaneamente o canto, o poema, o poeta, o leitor.

Na última estrofe, o eu lírico passa a perseguir esse "tu" duplamente material e imaterial, e ainda imagem refletida do próprio sujeito poético, que já se sente ‘completo' pela própria busca complexa e abrangente a que se compromete:

\footnotetext{
10 “A importância do orvalho em inúmeros rituais e preparações mágicas provém de sua virtude de saber resolver a oposição das águas de cima e de baixo, das águas terrestres e celestes. Ele é água pura, a água preciosa, a água do princípio por excelência" (CHEVALIER. GHEERBRANT, 2002, p. 665).
} 


\begin{abstract}
"Já agora te sigo a toda parte, e te desejo e te perco, estou completo, me destino, me faço tão sublime, tão natural e cheio de segredos, tão firme, tão fiel... Tal uma lâmina, o povo, meu poema, te atravessa."
\end{abstract}

Seguir-se, através do espelho do poema, na sua lâmina ora opaca ora cristalina, conduziria o sujeito que enuncia, e talvez o leitor, à promessa poética utópica de uma totalidade. E os dois últimos versos acima revelam uma imagem do paradoxo desse entrelaçamento entre poeta, poema e mundo. Numa primeira linha de leitura (possível) do verso, tal como uma lâmina, é o povo que atravessa o poema. É através do povo que acontece a crítica existente na composição lírica. Vê-se um movimento de fora para dentro. O mundo entrando no poema, enquanto povo. Numa segunda leitura, tal como uma lâmina, é o poema que atravessa o povo. O poema é a matéria crítica que vai atravessar o povo, num movimento de dentro para fora. Numa ainda terceira leitura, o povo seria o "meu poema", que, como uma lâmina, atravessaria o próprio poema. Ou seja, o movimento seria de dentro para dentro, numa fusão entre poema e povo.

Essa intrincada trama textual parece ainda mostrar o sentido ético-estético que permeará os poemas de A Rosa do Povo, uma relação tensional entre o eu lírico e o poeta que, desejando superar uma espécie de individualismo solitário em sua poesia (e quiçá na vida), vai buscar, por meio da constituição de um sujeito poético utópico, a possibilidade de um convívio social mais amplo, num constante jogo entre a ficcionalização do sujeito autobiográfico e a reinscrição desse eu ficcionalizado na realidade empírica, sendo o poema o único lugar em que essa gênese acontece.

Para Octavio Paz, todo poema seria um "modelo" do que poderia ser um mundo fundado na solidariedade. Neste, seria possível reunir harmonicamente as particularidades dos homens e 
exercitar-lhes a imaginação. De acordo com Paz, as obras de arte, e em especial a poesia, carregariam volições da coletividade, podendo os indivíduos nelas se reconhecerem:

"Por encima de cada subcultura - también por debajo - hay ideas, creencias y costumbres que son comunes a todos los miembros de la sociedad. Es el fondo - espiritual, mental, afectivo - de cada pueblo; asimismo, es el fundamento de las artes, especialmente de la poesía. Un manantial inegotable. Los hombres se reconocen en las obras de arte porque éstas le ofrecen imágenes de su escondida totalildad. Incluso cuando expresan la dispersión y la atomización de las sociedades y de los indivíduos, como ocurre con la poesía y la novela modernas, son un emblema de la perdida comunidad'. (PAZ. 1990, p. 73)

É sublinhado, nesse trecho, o aspecto de negatividade do poema moderno que, ao expor a fragmentação dos indivíduos em sociedade, estaria lidando com a busca por uma espécie de 'totalidade perdida'. O poema assume um caráter utópico, cuja função é a de se contrapor a um processo histórico de 'reificação', isto é, da separação entre a dimensão simbólica e a dimensão socioeconômica, pondo o indivíduo em contato com a perda de sua autonomia e autoconsciência.

Assim, em "Consideração do poema", entre as latências do "devir-povo" e do "devir-rosa", há a via ambígua e oscilante do "devir-poema", considerado como um possível lugar de inserção de um indivíduo em busca de totalidade. Por terem caráter utópico, os poemas não podem ser convertidos em direitos, em novas ordens sociais; mas, ainda assim, podem ser partilháveis enquanto obras de arte, cuja negatividade mobilize a consciência e a vontade de cada leitor a um movimento de recusa e de reelaboração das concepções da realidade. Um lugar em que as diferentes utopias se confrontam e se elaboram, se afirmam e se contradizem, reunindo-se em síntese precária, o que ressalta o elemento de modernidade do poeta, que deixa o seu estatuto autoral pleno para procurar, no poema, a discursividade de um mundo oscilante. 


\subsection{Tensão sob ambiguidade: "Procura da poesia"}

Apesar de notarmos em A Rosa do Povo a noção de uma poética afirmativa, mediante poemas nos quais se alcançaria uma espécie de comunhão, na rua, entre um eu lírico inicialmente particularista e a coletividade, e que por isso o definimos como um "sujeito lírico utópico", a ser constituído na articulação da unidade da obra, há inúmeros poemas que problematizam a possibilidade de existência e de utilidade do poema, sendo exemplos "Procura da poesia", "Carrego comigo", "Fragilidade". Nestes parece existir um movimento de 'essencialização' da poesia, como se esta se localizasse numa esfera inacessível, intangível, em torno do qual o poema apenas gravitaria enquanto espaço de procura, mas, simultaneamente, como o lugar em que a poesia se faz e se desfaz.

Em "Procura da poesia", a poesia é enunciada como se fosse um animal selvagem, uma força estranha, desconhecida, com a qual o 'poeta-poema' faria um corpo a corpo repleto de regras e restrições. Há aqui uma ideia de 'mistério' na relação do poeta com a poesia, o que talvez simbolize a própria relação do homem com o desconhecido, plena de respeito e de cuidado perante uma autoridade inquestionável:

\section{"PROCURA DA POESIA}

Não faças versos sobre acontecimentos.

Não há criação nem morte perante a poesia.

Diante dela, a vida é um sol estático,

não aquece nem ilumina.

5 As afinidades, os aniversários, os incidentes pessoais não contam.

Não faças poesia com o corpo,

esse excelente, completo e confortável corpo, tão infenso

[à efusão lírica.

Tua gota de bile, tua careta de gozo ou de dor no escuro

são indiferentes.

10 Nem me reveles teus sentimentos,

que se prevalecem do equívoco e tentam a longa viagem. 
O que pensas e sentes, isso ainda não é poesia.

Não cantes tua cidade, deixa-a em paz.

O canto não é o movimento das máquinas nem o segredo

[das casas.

15 Não é música ouvida de passagem; rumor do mar nas ruas

[junto à linha de espuma.

O canto não é a natureza

nem os homens em sociedade.

Para ele, chuva e noite, fadiga e esperança nada significam.

A poesia (não tires poesia das coisas)

20 elide sujeito e objeto.

Não dramatizes, não invoques,

não indagues. Não percas tempo em mentir.

Não te aborreças.

Teu iate de marfim, teu sapato de diamante,

25 vossas mazurcas e abusões, vossos esqueletos de família

desaparecem na curva do tempo, é algo imprestável.

Não recomponhas

tua sepultada e merencória infância.

Não osciles entre o espelho e a

30 memória em dissipação.

Que se dissipou, não era poesia.

Que se partiu, cristal não era.

Penetra surdamente no reino das palavras.

Lá estão os poemas que esperam ser escritos.

35 Estão paralisados, mas não há desespero,

há calma e frescura na superfície intata.

Ei-los sós e mudos, em estado de dicionário.

Convive com teus poemas, antes de escrevê-los.

Tem paciência, se obscuros. Calma, se te provocam.

40 Espera que cada um se realize e consume

com seu poder de palavra

e seu poder de silêncio.

Não forces o poema a desprender-se do limbo.

Não colhas no chão o poema que se perdeu. 
como ele aceitará sua forma definitiva e concentrada

no espaço.

Chega mais perto e contempla as palavras.

Cada uma

50 tem mil faces secretas sob a face neutra

e te pergunta, sem interesse pela resposta,

pobre ou terrível, que lhe deres:

Trouxeste a chave?

Repara:

60 ermas de melodia e conceito, elas se refugiaram na noite, as palavras.

Ainda úmidas e impregnadas de sono,

rolam num rio difícil e se transformam em desprezo."

Essa relação do poema com uma 'poesia misteriosa' não se dissociaria de uma ideia de transgressão, na medida em que ele se aproxima e se distancia da poesia, pronunciando palavras e criando imagens que lhe seriam inadequadas, retomando, de certa maneira, o mesmo procedimento contraditoriamente performático presente nos versos iniciais de "Consideração do poema": "Não rimarei a palavra sono / com a incorrespondente palavra outono".

Esse procedimento, que afirma um lugar na medida mesma em que o recusa, introduz elementos retóricos no discurso. Pois ao mesmo tempo em que busca desvelar o mistério que envolve o poético, o texto fecha-se aos olhos do leitor, conciliando as instâncias paradoxais do segredo e da exigência de comunicação, de modo a evitar que os poemas sejam interpretados somente no âmbito do prosaico, perdendo com isso a sua esfera simbólica.

Por outro lado, como notou Betina Bishof, o dinamismo da retórica drummondiana, entre uma expressão às vezes mais ensolarada e às vezes mais cifrada, seria também atravessado por um forte componente político: "a melancolia, o fechamento e a recusa podem aliar-se ainda a um 
posicionamento frente aos entraves do mundo (posicionamento do qual não está excluído um latente posicionamento político)" (BISHOF. 2005, p. 12). O estudo de Bishof concentra-se especialmente na poética de Claro Enigma, cujo enfretamento das questões sociais se dá de maneira menos direta e iluminada que na obra de 45 , em que a esperança de materialização de uma utopia social se mostrava mais presente. De todo modo, em sua análise de "Áporo" é explorado com profundidade um dos temas centrais de A Rosa do Povo, a saber, o processo de transformação do sujeito, da sociedade e da história, mediante uma superação do obstáculo, metaforizado pela negatividade da noite - "Que fazer, exausto, / em país bloqueado, / enlace de noite / raiz e minério?" -, para alcançar-se, então, a liberdade do dia claro, materializada na imagem da flor ou do próprio poema:

\author{
"Eis que o labirinto \\ (oh razão, mistério) \\ presto se desata: \\ em verde, sozinha, \\ antieuclidiana, \\ uma orquídea forma-se.”
}

Note-se que o processo de formação de "uma orquídea" parece reunir duas instâncias declaradamente paradoxais que compõem a poética drummondiana: o entrelaçamento entre a razão e o mistério, no deliberado ato de escrever, sempre em trânsito entre questões da terra, como o materialismo histórico e a política, e temas de natureza metafísica - tensão que perdurará em coletâneas futuras, como o indicam os seus próprios títulos, Claro Enigma e Fazendeiro do Ar.

Ainda mais do que na década de 1930, o contexto de fechamento político do início dos anos 40 exigia um posicionamento político por parte de intelectuais e artistas, especialmente em face da ditadura do Estado Novo e da Segunda Guerra Mundial. No estudo de Iumna Maria Simmon, Drummond: uma poética do risco, foi demonstrado pela primeira vez um dos mecanismos centrais 
de A Rosa do Povo decorrente dessa conjuntura política, a saber, a tensão entre o engajamento e a consciência da crise da poesia:

"Momento em que se acentua a antinomia básica do signo poético: impõe-se a necessidade de participação a uma forma artística que, pela essência de sua natureza, se recusa a ser instrumento de comunicação prática. Assim, a consciência da crise da poesia na obra de 45 vincula-se àquela tensão nuclear (entre autonomia e comunicação), catalizadora das demais tensões que percorrem todo o texto." (SIMON. 1978, p. 53)

Conforme Simon, o poeta teria assumido um risco ao incorporar elementos da prosa à poesia a fim de acentuar sua eficácia comunicativa, adotando procedimentos que não condiziam na época com uma noção de 'poesia pura', podendo torná-la, assim, menos poética. Por outro lado, haveria, numa postura contrária, o risco do autoisolamento, da ausência de diálogo com seu tempo e de um menor alcance entre leitores, o que representaria, talvez, uma característica de alienação do artista e de fragilidade da poesia face ao contexto. ${ }^{11}$

Lendo agora esse foco de tensão entre afirmação e crise do poema pelo viés do fenômeno utópico, retomamos as sugestões teóricas contidas no ensaio "Poema como utopia" de Henri Meschonnic. Para este, há uma modalidade da utopia definida como "desaparecimento do poema". Esta consiste numa "utopia passiva", na medida em que o poema sofre uma espécie de "destruição efetuada pela própria poesia", o que só é visível a um olhar prevenido, já que a cultura se utiliza de artifícios para ocultar a ausência do poema, por meio de uma aparência de presença. Segundo Meschonnic, uma das formas de "desaparecimento do poema” é a da "essencialização da poesia", ou seja, a noção de que esta é exclusivamente sublime, incognoscível, e que o poema não pode ser mais que um discurso evocatório da essência do poético:

\footnotetext{
11 Vale lembrar que Padre Antonio Vieira, quando buscava comunicar uma mensagem incialmente cifrada, já se defrontava com essa noção de risco na elaboração de um discurso mais explícito. Ao expor em demasia os 'sinais' nele contidos, o discurso poderia ser mal interpretado, restringindo, à esfera exclusivamente prosaica, as outras instâncias simbólicas do seu significado. De acordo com Alcir Pécora, ao conciliar um discurso ora comunicativo ora hermético, Antonio Vieira buscava, retoricamente, impedir que os "sinais" em seu texto fossem lidos a partir da noção de "uma enganada suficiência da matéria” (PÉCORA, 2008, p. 113). Segundo Pécora, Vieira reconheceria o risco de que o homem, inclinando-se somente sobre o aspecto material dos textos, deixasse de conduzir-se também ao seu aspecto misterioso, estando aí "o risco, como já se disse, de deformar o desejo natural a ponto de cristalizá-lo na completude imaginária da matéria" (idem, ibidem).
} 
"A essencialização da poesia, a própria ideia da poesia como essência, sendo esta essência inatingível, não pode produzir mais que um discurso de nostalgia da poesia, de apelo à poesia, de evocação encantatória da poesia, que como tal não é e não faz um poema, a menos então que se chame poema à própria poetização da poesia." (MESCHONNIC. 2009, p. 209)

Nos dois primeiros poemas de a A Rosa do Povo, é enunciada a poética que atravessará toda a obra, expondo o dinamismo sempre tenso e simultâneo entre a noção de um poema afirmativo, socializante e engajado, conforme se pode ver em "Consideração do Poema", e a noção de que o poema não seria mais que um ornamento da poesia - essencial e intocável -, e que o seu modo de atuação no mundo seria necessariamente restrito e ineficaz, no que toca ao poder de gerar transformações sociais, como se lê em "Procura da poesia".

Neste segundo poema, a poesia seria intransitiva, como no verso "elide sujeito e objeto", mas também condição do poema, sendo por isso uma instância ambígua e paradoxal. Para desdizer o que é interdito, "não tires poesia das coisas", o poema fala o que não deveria. Há o mistério, mas só se pode alcançá-lo pela transgressão. O poema cria um lugar de possível encontro entre o real e o irreal, e, simultaneamente, uma ideia de aproximação do poema à poesia e de distanciamento entre ambos, pela transgressão do primeiro, ao dizer coisas inadequadas. A poesia seria uma esfinge? Um animal mítico? Uma autoridade? Uma força indevassável escondida "sob a face neutra" das palavras? Ou simplesmente uma composição verbal?

"Não cantes tua cidade, deixa-a em paz.

O canto não é o movimento das máquinas nem o segredo das casas.

Não é música ouvida de passagem; rumor do mar nas ruas junto à linha de espuma.

O canto não é a natureza

nem os homens em sociedade.

Para ele, chuva e noite, fadiga e esperança nada significam.

A poesia (não tires poesia das coisas)

elide sujeito e objeto. 


\section{(...)}

Não osciles entre o espelho e a

memória em dissipação.

Que se dissipou, não era poesia.

Que se partiu, cristal não era."

É como se o poema estivesse falando para si mesmo, numa espécie de monólogo com a sua própria imagem refletida, no que estaria subentendida uma identificação entre o eu poético e o poema. Este seria como um corpo que ora mergulha no sono, ora se reflete no cristal, transitando ao mesmo tempo entre essas duas polaridades, gerando assim a ideia de paradoxo: é a coisa, mas é também a imagem refletida da coisa; é reflexo, e por isso está fora a procurar a poesia, mas simultaneamente é a própria matéria composta por palavras, na qual se forma a poesia. O sono seria a metáfora da "memória em dissipação", da obscuridade, da passividade, do inconsciente. O cristal seria a metáfora do límpido, da consciência, da forma conquistada por meio da lapidação, contra a passividade do que é líquido e amorfo. O poema, oscilante entre o cristal e o sono, seria, talvez, a metáfora do próprio ser humano, composto por essas duas instâncias.

Mas para romper com a oscilação compartimentada entre temas poéticos supostamente antagônicos e inconciliáveis, os quais são enumerados ao longo do poema - o corpo, os sentimentos, a cidade, a música, a natureza, a sociedade, a família, a memória, as coisas -, o sujeito poético prescreve uma espécie de 'pacto com as palavras', ${ }^{12}$ na medida em que elas, sendo a matéria prima da poesia, comportam em si a multiplicidade sonora e conceitual necessária à criação de poemas com maior complexidade e eficácia poética:

\footnotetext{
${ }^{12} \mathrm{Na}$ apresentação à coletânea Poemas Ingleses de Guerra (1942), organizada e traduzida por Abgar Renault, Drummond já havia comentado acerca da ideia de que os poetas conseguem exprimir os dramas do "homem comum", porque realizam uma 'aliança com as palavras': “E o que esse homem comum não pode exprimir, o poeta, mercê de sua aliança com as palavras, e por via de um secreto maquinismo, nos apresenta sob a especie de um concentrado e patético lirismo, não apenas inglês, mas universal e humano" (RENAULT. 1942, p. 3).
} 
"Penetra surdamente no reino das palavras.

Lá estão os poemas que esperam ser escritos.

Estão paralisados, mas não há desespero,

há calma e frescura na superfície intacta.

Ei-los sós e mudos, em estado de dicionário.

Convive com teus poemas, antes de escrevê-los.

Têm paciência, se obscuros. Calma, se te provocam.

Espera que cada um se realize e consume

com seu poder de palavra

e seu poder de silêncio.

Não forces o poema a desprender-se do limbo.

Não colhas no chão o poema que se perdeu.

Não adules o poema. Aceita-o

como ele aceitará sua forma definitiva e concentrada no espaço.

Chega mais perto e contempla as palavras.

Cada uma

tem mil faces secretas sob a face neutra

e te pergunta, sem interesse pela resposta,

pobre ou terrível, que lhe deres:

Trouxeste a chave?

Repara:

ermas de melodia e conceito,

elas se refugiaram na noite, as palavras.

Ainda úmidas e impregnadas de sono,

rolam num rio difícil e se transformam em desprezo."

O sujeito poético contrapõe dois movimentos em "Procura da poesia". Na primeira parte (que se encerra no verso "Que se partiu, cristal não era"), faz uma espécie de mapeamento de "nãos", isto é, um inventário das armadilhas que impossibilitariam o poeta de encontrar a poesia, caso ele se detivesse a uma noção de que os temas e os sentidos seriam primordiais ao poético, de modo que as palavras fossem somente os signos deles. No segundo movimento, o eu lírico afirma a primordialidade das palavras, sendo elas as entidades corpóreas a serem buscadas pelo poeta, cuja 
ambiguidade, que lhes é inerente, propiciaria a realização e consumação do poema em sua plena potencialidade.

Citando Burckhardt, Michael Hamburger discute a questão do compromisso do poeta com a palavra. O modo como esse comprometimento, com algo ambíguo e paradoxal, é capaz de pôr em jogo tudo o que artista imaginava em relação a si mesmo e ao mundo, retirando-o de uma zona de conforto, na medida em que o poema é a imagem refletida do que o poeta pensa:

“O poeta estaria muito mais seguro (...) se não se comprometesse com a Palavra (...). Enquanto o filósofo busca a certeza no signo - o 'p' do cálculo proposicional - e o místico, no inefável - o "OM" dos hindus - o poeta toma para si o paradoxo da palavra humana, que é ambos e nenhum, e que ele criativamente transforma em sua 'rima poderosa'. Essa rima é seu feito; ela dissocia, dissolve a palavra em seus componentes - marca e ladrido - mas simultaneamente a funde numa união nova e agora sacramental." (HAMBURGER. 2007, p. 56)

De maneira semelhante à reflexão acima, a prescrição de um pacto com as palavras, em "Procura da poesia", enuncia uma poética do livro, na medida mesma em que se mostra um poema que reúne instâncias supostamente inconciliáveis, pondo em tensão o convívio entre temas poéticos e polaridades, como a do sono e a do cristal, os quais serão, ao longo da obra, cada vez mais amalgamados. Esse trabalho intenso e direto do poeta com as palavras parece ter também como objetivo, segundo Michael Hamburger, a superação "da dicotomia desgastada entre o pensamento e as coisas" (HAMBURGER. 2007, p. 48).

Aludindo à analogia feita por Ponge, entre o trabalho poético e a alquimia, ${ }^{13}$ Hamburger entende que, concomitantemente ao processo de exploração das potencialidades das palavras, haveria na poesia moderna a ação de constituição de um novo sujeito poético: "A referência de

\footnotetext{
13 "Meu método, com certeza, não é o da contemplação no sentido estrito da palavra, mas, de preferência, um método tão ativo, que o ato de nomear se segue de imediato; trata-se de uma operação com a caneta na mão, de modo que percebo analogias mais próximas na alquimia... e geralmente na ação, também (incluindo a ação política), do que em algum tipo de êxtase que se origina apenas no indivíduo e que sobretudo me faz rir." (PONGE, apud HAMBURGER. 2007, p. 46)
} 
Francis Ponge à alquimia nos obriga a fazer face ao caráter de intercâmbio de sujeito e objeto em grande parte da poesia moderna" (idem, p. 47). Isso porque, na medida em que o eu lírico pratica os seus trabalhos nos signos verbais, convertendo-os em poemas, estes atuariam simultaneamente sobre o eu ficcionalizado, assim como sobre o próprio sujeito empírico, na forma de imagem refletida de sua consciência, a qual, por ser imagem, se situaria também no interior de um processo de transformação operado pela palavra poética.

Outro poeta que articulou a simbologia da alquimia com a poesia foi Fernando Pessoa. No texto “A química oculta, ou alquimia, difere da química vulgar”, Pessoa demonstra que a distinção entre ambas reside no modo pelo qual cada uma delas se apropria dos resultados de suas experiências químicas sobre a matéria. Na química vulgar, o cientista se restringiria aos resultados materiais, pois sua busca seria a de transformar e a de dominar a matéria, tornando-se "dono" dela. Já o alquimista estaria buscando transformar o que a matéria simboliza, tentando dominar a sua "força simbólica", a qual acabaria por afetar o próprio operador e as pessoas que estão envolvidas nesse trabalho, conscientes ou não dos meios empregados:

“A química oculta, ou alquimia, difere da química vulgar ou normal, apenas quanto à teoria da constituição da matéria; os processos de operação não diferem exteriormente, nem os aparelhos que se empregam. É o sentido, com que os aparelhos se empregam, e com que as operações são feitas, que estabelece a diferença entre a química e a alquimia. (...) Mas, ao mesmo tempo, os elementos que compõem a matéria têm um outro sentido: existem não só como matéria, mas também como símbolo. Há, por exemplo, um ferro-matéria; há, porém, e ao mesmo tempo, o mesmo ferro, um ferro-símbolo. Cada elemento simboliza determinada linha de força supermaterial e pode, portanto, ser realizada sobre ele uma operação, ou acção, que o atinja e o altere, não só no que elemento, mas também no que símbolo. E, feita essa operação, o efeito produzido excede transcendentalmente o efeito material que fica visível, sensível, mensurável no vaso ou aparelho em que a experiência se realizou. É esta a operação alquímica. E isto no seu aspecto externo: porque, na sua realidade íntima, é mais alguma cousa do que isto. Como o físico (incluindo no termo o químico também), ao operar materialmente sobre a matéria, visa a transformar a matéria e a dominá-la, para fins materiais; assim o alquímico, ao operar materialmente quanto aos processos mas transcendentemente quanto às operações, sobre a matéria, visa a transformar o que a matéria 
simboliza, e a dominar o que a matéria simboliza, para fins que não são materiais. A semelhança, porém, pára aqui. O resultado da experiência física é um produto externo, com que o operador não tem nada, excepto vê-lo, ou ser dono dele, se o é. Mas na experiência alquímica a «força», que o corpo trabalhado simboliza, está em contacto directo com o espírito do operador, e não só do operador, como também de quantos conscientemente o auxiliam (embora sem conhecimento alquímico) nas suas experiências. O resultado da experiência, portanto, afecta o operador e os seus «adjuntos» (como se diz) de uma forma diversa e diversamente importante." 14

Apesar de propor um 'pacto com as palavras', há em "Procura da poesia" uma noção acerca do limite do humano diante da autonomia delas. ${ }^{15}$ As palavras são corpos que, mesmo sendo trabalhados exaustivamente, não são nunca completamente dominados pelo poeta, no tocante à sua 'força simbólica'. Esta força, no entanto, acaba sempre por afetar o sujeito poético, o sujeito empírico e o leitor, transformando-os, por exemplo, em "uma coisa tão diversa / da que pensava que fôssemos", como se lê no poema "O mito".

Podemos pensar o estilo drummondiano como expressão da recusa da ideia de fixação definitiva, num corpo de palavras, dos movimentos de um pensamento fragmentado, que transita sempre de um tema para outro, a despeito da natureza contraditória que eles tenham entre si. Segundo João Adolfo Hansen, “o estilo [de Drummond] é justamente a negação da completude da memória na experiência do presente, pois figura a razão dividida que analisa sua própria falta de ser e unidade nas formas incompletas ou contingentes do devir da sensação" (HANSEN. In DRUMMOND DE ANDRADE. 2011a, p. 256). Ou seja, o estilo do poeta mineiro materializa uma contínua experiência de dissolução da ideia de algo ou de alguém que alcançasse uma espécie de "plenitude de maturação", indicando assim a condição de um sujeito poético ou um poema em perpétuo 'retorno' sobre si mesmo.

\footnotetext{
${ }^{14} \mathrm{In}$ : http://arquivopessoa.net/textos/662, acessado em 07.07.2013.

${ }^{15}$ Exemplo dessa noção de limite do humano em face das palavras, para Drummond, é lido no poema "O lutador", de José (1942): "Lutar com palavras / é a luta mais vã. / Entanto lutamos / mal rompe a manhã. / São muitas, eu pouco. / Algumas, tão fortes / como um javali. (...) Luto corpo a corpo, / luto todo o tempo, / sem maior proveito / que o da caça ao vento. (...)",
} 
Essa tensão gera um impasse constante entre aproximação e distanciamento do poema em relação à poesia, havendo, aparentemente, uma fusão entre os elementos díspares operada pela ambiguidade, que multiplicaria os sentidos e proporcionaria, talvez, a sensação de um convívio harmônico entre as coisas dissimétricas, suavizando os contornos da dissimetria, das coisas como díspares, não se podendo ver, com clareza, a relação sempre tensa que o poema tem consigo mesmo. A duplicidade seria como uma primeira camada que possibilita múltiplas leituras, desviando o leitor da tensão nuclear que perpassa o poema - corpo composto por palavras ambíguas e paradoxais -, que é de recusa, de violência, de negatividade, expondo, assim, as inúmeras dificuldades a serem superadas para a composição de um canto ampliado, e instaurando uma crise na própria noção de um poema afirmativo, criador de utopias e inventor de um novo sujeito poético socializante.

\subsection{Dissolução na noite: "Anoitecer"}

O poema "Anoitecer" se compõe com a temática do noturno no conjunto da obra, em que o caráter de negatividade do canto é acentuado, de modo a promover a dissolução de uma realidade constritora:

\section{“ANOITECER}

É a hora em que o sino toca, mas aqui não há sinos; há somente buzinas, sirenes roucas, apitos

5 aflitos, pungentes, trágicos, uivando escuro segredo; desta hora tenho medo.

É a hora em que o pássaro volta, 10 mas de há muito não há pássaros; só multidões compactas 


escorrendo exaustas
como espesso óleo
que impregna o lajedo;
desta hora tenho medo.
É a hora do descanso,
mas o descanso vem tarde,
o corpo não pede sono,
depois de tanto rodar;
pede paz - morte - mergulho
no poço mais ermo e quedo;
desta hora tenho medo.
Hora de delicadeza,
gasalho, sombra, silêncio.
Haverá disso no mundo?
É antes a hora dos corvos,
bicando em mim, meu passado,
meu futuro, meu degredo;
desta hora, sim, tenho medo.”

Partindo da leitura dos dois primeiros versos, poderíamos defini-las como duas orações enunciativas, sentenças que expressam de forma assertiva a realidade apreendida pelo poeta, mantendo um distanciamento entre a objetividade do mundo e a interioridade do eu lírico. Esse entendimento se justificaria em vista da "autocrítica implacável, espécie de inteligência da sensibilidade que impede a menor manobra em falso" (BUARQUE DE HOLANDA. 1996, p. 560), atribuída a Drummond por Sérgio Buarque, a qual dificultaria o poeta a internalizar completamente a realidade concreta, bem como a expressar-se por meio da canção.

Mas percebemos logo nas primeiras estrofes uma forte carga de subjetividade a impregnar a descrição do mundo exterior. Primeiro, há a referência à hora do dia em que toca o sino. Já no início do segundo verso há a conjunção adversativa "mas", seguida pelo adjunto adverbial de lugar 
"aqui", ${ }^{16}$ ambos a contraporem essa hora ao lugar onde inexistem sinos, onde predominam buzinas, sirenes, apitos - ruídos estridentes e incômodos -, adjetivados ainda por roucas, aflitos, pungentes, trágicos, os quais, no uso corrente, qualificariam outros substantivos, mas, aqui, sofrem transposição por meio do eu poético, dando-se vida aos sons, que uivam um segredo amedrontador. Nas demais estrofes o procedimento é o mesmo: faz-se nos dois primeiros versos alusão a determinada hora do dia em que algo deveria ocorrer ou existir, o que já não é mais possível, na medida em que o mundo se desumanizou aos olhos do poeta, que descreve a realidade que o cerca, carregando-a de subjetividade.

A partir dessa constatação inicial, de que o mundo exterior se encontra fundido à subjetividade do eu lírico, poderíamos dizer que a atitude lírica do poema é a da canção, diferentemente do que ocorre em "Campo de flores", de Claro Enigma (1951), em que há certo distanciamento entre sujeito e objeto, dando lugar a uma exposição mais distanciada e objetiva do tema. No conhecido ensaio "Leitura de "Campo de flores"”, João Luiz Lafetá atribui o tom enunciativo do poema à ironia drummondiana, na medida em que esta, fundada que está num princípio racional de constatação do absurdo das coisas existentes, impediria a fusão entre o elemento exterior e a subjetividade do eu lírico, mantendo-o sempre numa postura distanciada e rascante:

"A ironia deve ser entendida, aqui como em muitos outros de seus poemas, não como sarcasmo ou como simples figura de linguagem, mas como uma postura básica, que apercebe-se do contraditório que existe nas coisas e apossa-se do doloroso que daí resulta. Compreendida desta forma, a ironia (ou corrosão...) torna-se elemento estruturante do poema e torna fácil compreender o porquê do tom de canção jamais ser alcançado. A postura irônica é essencialmente objetiva, impede que a interiorização do sentimento seja plenamente realizada.” (LAFETÁ. 2004, p. 53)

\footnotetext{
${ }^{16}$ Note-se que este adjunto, pela sua natureza de aproximação, já nos remete a um lugar não divorciado da subjetividade do eu lírico.
} 
Não vemos ironia em “Anoitecer”, mas sim a presença de outros elementos estruturais a confirmar a forma idílica da canção. A começar pelo fato de as quatro estrofes que o compõem não se subordinarem entre si, o que retira ao poema a característica de uma sintaxe discursiva, que o aproximaria mais da atitude lírica enunciativa. Cada uma delas é capaz de expressar, pela forma por que se apresenta, a sua gama de significados; não há a necessidade de que uma estrofe atue em conjunto com outra de modo a se complementarem, pois são unidades sintáticas independentes, sem vínculo de subordinação. Contudo o paralelismo e o encadeamento existente entre elas, a repetição de ideia nas estrofes, somada à repetição anafórica das palavras iniciais dos dois primeiros versos e as do último, criam um movimento circular no poema, girando em torno da subjetividade de quem canta. E, da mesma forma pela qual Wolfgang Kayser se refere à segunda "Canção Nocturna do Viandante", de Goethe, na qual a palavra "paz" do segundo verso se repete ao final, com peso e profundidade mais significativos, no poema "Anoitecer" a palavra "medo" dirige-nos para uma noção de profundidade, ganhando a cada estrofe conteúdo cada vez mais amplo, atingindo, ao final, uma integração completa entre o mundo exterior e o sujeito, ambos se interagindo, o que se intensifica, ainda, com a rima entre os dois últimos versos de cada estrofe, com evidente fim expressivo nesse sentido.

Inexistem sinos no mundo cantado pelo poeta. É a sua primeira constatação ao cair da noite, momento em que eles deveriam tocar. E essa ausência, preenchida pelos ruídos da cidade, pungentes em sua agudez e desordem, deflagra não só a passagem e a transformação de um mundo arcaico, campesino, para o das grandes cidades (o que pode refletir a própria trajetória do autor, que partiu de Itabira para o Rio de Janeiro), como também revela o desaparecimento de um ritmo que remeta a uma noção de sagrado (os sinos como metonímia e símbolo de templos), e a prevalência do profano que impera nas metrópoles. Essa noção de sagrado simbolizaria o homem, cujo ritmo natural seria vilipendiado pela modernidade. A dissociação entre o ritmo biológico e o ritmo imposto pela sociedade, portanto, parece ser um dos temas centrais do poema, como o é ao longo da obra de Carlos Drummond de Andrade, conforme observado por Sérgio Buarque: 
"O artifício dos intercâmbios, das acomodações de superfície, do espetáculo diário e convencional, envolvendo e procurando a todo instante sobrepujar o que na vida há de mais vivo, mais íntimo, mais isento de compromissos externos e que parece vir do fundo dos tempos: esse o tema constante de Carlos Drummond de Andrade." (BUARQUE DE HOLANDA. 1996, p. 559)

Logo nos três primeiros versos de "Anoitecer" se enuncia este tema, que depois é abordado por ângulos diversos nas estrofes seguintes. Na primeira, há a referência metafórica à metrópole que, ante a ausência de um ritmo que remeta a uma noção de sagrado, não concede mais espaço à melodia dos sinos, que, como nas palavras de Rubem Braga, seria algo precioso: "de todos os ruídos e sons que saem do mundo (...) Deus, com especial delícia e alegria, ouve o som alegre do sino de ouro perdido no fundo do sertão" (BRAGA. 1979, p. 51). Na segunda estrofe, passa-se da alusão à metáfora da cidade para as multidões que a habitam. Não há mais referência a objetos inanimados, como sinos e apitos, mas a seres vivos, tais pássaros e multidões, e por consequência à situação destas, exauridas no meio opressivo em que se encontram. Na terceira, estes seres vivos e indefinidos são individualizados num corpo, que tem necessidades próprias e sofre diante da rotatividade mundana que lhes é imposta, e pede paz através da morte. E na última, o corpo, antes tratado com distanciamento, toma a voz do poeta (e a consciência, como abordaremos adiante) fato que, aliás, confirma o tom de canção do poema -, revelando as diversas formas por que é tratado o tema do ritmo natural do homem na cidade moderna, gradativamente do coletivo massificado para o individual.

Este tema também é abordado de forma significativa no ritmo do poema. Nas duas primeiras estrofes há elevada oscilação no número de sílabas dos versos. Na primeira, um tem oito sílabas (verso 1), dois têm seis (versos 2 e 3), e os quatro últimos têm sete; na segunda, um tem nove sílabas (verso 8), um tem oito (verso 9), um tem seis (verso 10), três são redondilhas menores 
(versos 11 a 13), e um tem sete (verso 14). Já nas duas estrofes finais predominam as redondilhas maiores, com exceção do ultimo verso, de oito sílabas (verso 28).

Como se mencionou, o poema discorre sobre o tema do ritmo do homem de forma gradativa, partindo do geral para o particular. Assim, o mundo moderno e as multidões que o habitam, sendo tratados nas duas estrofes iniciais por meio de versos irregulares, parecem ser, para o poeta, desordenados como a ausência da métrica; os ruídos da cidade, ao contrário do badalo dos sinos, não comportam qualquer similitude, simbolizando o caos. A terceira e a quarta estrofes, que versam sobre o ser humano, têm como unidade métrica a redondilha maior. Logo, a partir da contraposição da métrica das estrofes iniciais e das finais, pode-se interpretar que o homem, que contém o seu ritmo biológico inalterado, diverge (e sofre) com o contexto arrítmico que o cerca.

Podemos ainda discorrer sobre outros recursos rítmicos utilizados no poema, como o fato de nos versos 11 e 12, de cinco sílabas, que descrevem o movimento das multidões "escorrendo exaustas / como espesso óleo", apresentarem o mesmo corte métrico 3-/-2, representando o movimento uniforme desse escorrimento pegajoso. Por outro lado, pode-se pensar que a escolha das redondilhas maiores nas estrofes finais, como representativas do ritmo do homem, estaria relacionada a um dos temas centrais de A Rosa do Povo, o da poesia social, a que o poeta se reporta em tom de apóstrofe lírica nos últimos versos de "Consideração do poema": "Tal uma lâmina, /o povo, meu poema, te atravessa." Os versos de sete sílabas representam o metro de maior identificação com o cancioneiro popular.

O fato é que em "Anoitecer" o poeta se vale de variados segmentos rítmicos para intensificar o significado do que pretende expressar. Como notou Sérgio Buarque, Drummond "pode assimilar e domar quaisquer influências exteriores sem seguir verdadeiramente os figurinos da moda" (BUARQUE DE HOLANDA. 1996, p. 566). Com efeito, a principal razão para que os versos drummondianos apresentem certa aspereza se deve à intensidade dos problemas abordados, impelindo o poema a organizar-se em torno deles, muitas vezes a despeito da unidade do verso. 
A poesia de Drummond é marcada por um enorme esforço de reflexão, um debruçar-se sobre a realidade, sobre os próprios sentimentos, sobre as questões da existência humana, sobre a poesia, sobre as palavras, sobre tudo que o circunda e o penetra. Uma sensibilidade aguçada aliada a uma inteligência perscrutadora, inquieta, que sempre procurou uma razão oculta no existente (a "máquina do mundo", o amor crepuscular mas destrutivo, o descompasso entre o ritmo natural e o ritmo das máquinas), razão essa velada, no entanto, por sombras, pela noite, e obstada por pedras, paredes, labirintos.

Retomando a constatação de que o poema “Anoitecer" se desenvolve de forma gradativa, de estrofe em estrofe, de um “aqui”" geral para um particular, notamos nesse movimento a indicação de um momento do processo de constituição do novo sujeito lírico que se dará ao longo do livro, como se o sujeito começasse a trabalhar com a dissolução de uma espécie de 'inconsciente coletivo', ou seja, do "chumbo da atmosfera constritora" (retomando o verso do poema "Retorno", de Fazendeiro do Ar), para adentrar na especificidade do indivíduo, consciente de sua realidade e de suas profundas carências. ${ }^{17}$

Inicialmente há a metáfora de um ambiente opressor, dessacralizado, a emitir ruídos pungentes que anunciam um tenebroso segredo, de que o poeta tem medo mas ainda não sabe o porquê. Em seguida, os seres inanimados passam a ter vida. Numa terra há muito tempo sem pássaros - seres que voariam em céu aberto -, há multidões padronizadas se arrastando no chão, por cansaço, escorrendo como óleo sobre uma superfície de concreto, infértil. Um medo ainda desconhecido. Na terceira estrofe, já existe um corpo que pede descanso, mas não o recebe a tempo, e por isto não se conforta mais com algumas horas de sono, depois do dia extenuante que lhe tira o sangue, em paga do progresso. O pedido, portanto, é de morte, e o eu lírico demonstra que nesta

\footnotetext{
${ }^{17}$ Betina Bischof ressalta com agudez uma espécie de "fascínio da dissolução" na poesia de Drummond, como se a sua carga histórica assumisse sempre o aspecto de uma "história que se dirige, inevitavelmente, para a queda, para a dissolução" (BISCHOF. 2005, p. 71). Ou seja, retomando o "princípio-corrosão" estudado por Luiz Costa Lima em Lira \& Antilira. Mário, Drummond, Cabral (1995), a estudiosa sublinha que a relação do poeta com a contemporaneidade decorreria também de um seu olhar crítico sobre o resultado das transformações do passado que vieram a desembocar no tempo presente, de modo que "se o presente é visto como uma época escurecida, há coerência na interpretação que enxerga o processo histórico que nele deságua como derrocada e dissolução" (idem, p. 73). Assim, haveria, por exemplo, um vínculo entre o processo de decadência da região das Minas Gerais iniciada no século XVIII e as ideias de dissolução e de fragmentação na poesia drummondiana.
} 
realidade o corpo autonomamente, mesmo inconsciente de seu ritmo, já não deseja viver. E o medo continua, aqui, como nas estrofes anteriores, sem motivo definido.

$\mathrm{Na}$ última estrofe, o verso inicial não se inicia com verbo nem com artigo definido a precederem a palavra "hora". Esta inicia o verso em letra maiúscula, evidenciando que o poeta, após refletir sobre o contexto que o cerca, individuou-se, tomando consciência de que o homem necessita, enfim, de delicadeza, de poesia. Assim, pela primeira vez, se manifesta de forma interrogativa, questionando a existência delas no mundo. Em resposta, porém, chega à constatação de que a hora é, antes, a dos corvos, que, igualmente ao corvo de Edgar Allan Poe, têm a função de trazer ao poeta a consciência da noite, a qual se caracteriza tanto aqui quanto no poema "O corvo" de Poe, como um símbolo da impossibilidade, da falta de saída política, do degredo definitivo, do “nunca mais”. Mas também atua como símbolo da integração do princípio obscuro (a sombra) na consciência do sujeito poético, de modo que a esfera do inconsciente passasse também a ser sentida como parte do corpo. E o eu se aterroriza com essa constatação, tanto que no último verso ele introduz a palavra "sim", no mesmo verso que vinha sendo repetido de forma idêntica nas estrofes anteriores, de modo a afirmar que, com a consciência do mundo de opressão em que vive e de suas carências, a dor é maior.

O símbolo do corvo indica ainda, na alquimia, um estágio inicial da obra que está sendo produzida, o momento em que o corpo sólido entra num processo de dissolução e de putrefação, denominado como a fase de negridão (nigredo), para, ao final, sofrer novo processo de solidificação, alcançando já um estágio superior da matéria, simbolizado pelo ouro. Esse estágio da obra alquímica é explicado por Serge Hutin:

"A dissolução é uma das operações da Grande Obra material, mas esse símbolo alquímico da morte nos três reinos também serve admiravelmente para caracterizar a condição preliminar à iluminação. A 'morte', a 'putrefação', a ‘cabeça de corvo', é a fase inicial necessária às transformações ulteriores da 'matéria prima' da Obra, mas é também um símbolo de um incontestável significado metafísico, e também, uma alusão muito 
característica à condição anterior a toda iniciação: a 'morte' para o mundo profano como prelúdio necessário ao ‘nascimento' do iniciado ao mundo sagrado.” (HUTIN. 1999, p. 124)

A propósito da discussão acerca da noção de uma obra poética dividida em fases para sua elaboração, vale notar que os poemas de abertura de Claro Enigma e de Fazendeiro do Ar, respectivamente "Dissolução" e "Habilitação para a noite", também expressam uma atmosfera de 'descida da noite', de enegrecimento. ${ }^{18}$

Se analisássemos o poema “Anoitecer" de maneira isolada, ou seja, fora do contexto do livro em que está inserido, poderíamos afirmar que o eu lírico passa por um processo de conscientização de si, pintando um quadro de absoluta negatividade, em que não seria proposta nenhuma saída. Mas o poema cresce em significados se analisado como parte da estrutura da obra. Depois dos quatro poemas iniciais - que, a nosso ver, parecem enunciar alguns tópicos essenciais da poética de $A$ Rosa do Povo, como: a afirmação de um poema utópico socializante (“Consideração do poema”), a necessidade de um pacto com as palavras ("Procura da poesia"), a conscientização da realidade exterior ("A flor e a náusea"), o resguardo da individualidade e da sua relação com um mistério indevassável ("Carrego comigo"), "Anoitecer" apareceria como a metáfora do processo de dissolução de noções de realidade solidificadas, tanto objetivas quanto subjetivas.

\footnotetext{
18 "Dissolução": "Escurece, e não me seduz / tatear sequer uma lâmpada. / Pois que aprouve ao dia findar, / aceito a noite. (...)"; "Habilitação para a noite": "Vai-me a vista assim baixando / ou a terra perde o lume? (...) Outra noite vem descendo / com seu bico de rapina."
} 


\title{
2. Mergulho na individualidade: dissolução do mundo coagulado
}

\subsection{A utopia do resgate da infância: "Nos áureos tempos"}

\begin{abstract}
"Em nossa vida sentimental apenas acumulamos mercadorias preciosas, que nos será dado usufruir em estado de nostalgia?" (Drummond. "Segredos". Passeios na ilha)
\end{abstract}

Numa primeira leitura do poema "Nos áureos tempos", de A Rosa do Povo, pode-se observar a referência ao mito grego das cinco idades do mundo, a saber, a idade do ouro, a idade de prata, a idade de bronze, a idade dos heróis e a idade de ferro, mito que representa o processo de degradação que a humanidade sofreu no decorrer do tempo, indicando que o homem vivia originariamente em melhor situação que a atual. Esse mito foi explorado literariamente por inúmeros autores ao longo da história, tendo como paradigma o poeta Hesíodo, cujas obras Teogonia e Os trabalhos e os dias vieram a inaugurar uma nova forma de pensamento na Grécia. ${ }^{19}$ Sob forte influência de Homero, Hesíodo foi o primeiro autor a transformar o mundo heroico e atemporal da epopeia clássica, de matriz aristocrática e universalizante, num canto em primeira pessoa voltado para o presente, cujo ponto de vista partia do modo de vida e das aspirações dos camponeses, ou seja, das pessoas simples do povo, com as quais o poeta compartilhava a mesma origem e o convívio.

Interessa-nos à análise do poema "Nos áureos tempos" comentar as idades de ouro, de bronze e de ferro. Na idade de ouro, a primeira, deuses e mortais viviam juntos num lugar na planície de Mecona, na Grécia, onde participavam dos mesmos banquetes, das mesmas comemorações, e todos os dias eram de festa, existindo apenas a felicidade. As terras da planície eram abundantes e infensas a intempéries, proporcionando alimentos espontânea e

\footnotetext{
${ }^{19}$ O poeta latino Ovídio, por exemplo, por retratar uma época em que o Império Romano havia recém conquistado a Grécia e que por consequência incorporou a mitologia a grega à sua, inspirou-se também em Os trabalhos e os dias de Hesíodo para narrar as "Idades do Mundo" na sua obra Metamorfoses.
} 
ininterruptamente ao longo do ano, e não havia a necessidade do cultivo da terra para a subsistência. Os homens não morriam nem envelheciam. Naquele tempo eles não conheciam sofrimentos, nem trabalhos extenuantes, nem a morte. Segundo Jean-Pierre Vernant, a idade de ouro é "quando os deuses e os homens ainda não estavam separados (...). É a paz, é um tempo antes do tempo. E os homens têm aí o seu lugar" (VERNANT. 2006a, p. 56-57). É também um tempo em que as mulheres mortais ainda não haviam sido criadas, existindo apenas deusas a representar a noção do feminino. Na Teogonia e em Os trabalhos e os dias, Hesíodo atribui a Prometeu a responsabilidade pelo divórcio entre os deuses e os homens, pois ele, ao roubar o fogo de Zeus para levá-lo aos humanos, despertou a ira do rei do Olimpo, que, por vingança, ordenou a Hefesto, Afrodite, Atena e Hermes que criassem um ardil a ser entregue aos mortais, na forma de uma mulher belíssima e virgem, mas que escondia um "espírito de cadela" e um "temperamento de ladra". Pandora seria adorada pelos homens, ao mesmo tempo em que os infernizaria eternamente, por reunir em si as desgraças da vida humana e o seu aspecto sublime, relacionado à sua beleza e sedução.

$\mathrm{Na}$ idade de bronze, a terceira, os homens estariam ocupados com as obras de guerra ligadas a Ares, sendo um momento em que, na metalurgia, aprenderam a unir o cobre ao estanho, alcançando o feitio de armas e casas de bronze, pois não conheciam ainda o ferro. Eram duros, fortes, invencíveis, mas morriam guerreando entre si.

Na idade de ferro, a última, Hesíodo lastima ter nascido nela - "Antes não estivesse eu entre os homens da quinta raça, I mais cedo tivesse morrido ou nascido depois" (HESÍODO. 2008, p. 33) -, posto que, durante o dia, os humanos se submeteriam a penosos trabalhos e, à noite, sofreriam angústias terríveis, não havendo paz nem descanso. Entretanto, o poeta relativiza o caráter negativo do seu presente, reconhecendo que, entre todos os males, haveria bens misturados, o que reforçaria “a tensão entre Hýbris (Desmedida, Excesso) e Dýke (Justiça)" (NEVES LAFER. In: HESIODO. Op. cit., p. 78), a qual orientaria toda a arquitetura deste mito, segundo a tradutora e comentarista de Os trabalhos e os dias, Mary de Camargo Neves Lafer, citando Vernant. Conforme a tradutora de Hesíodo, cada uma das idades do mundo estaria ligada a um período da vida humana: 
"Primeiro, as raças de ouro e de prata não têm nenhum conhecimento da necessidade, tudo lhes é doado espontaneamente, vivem sem preocupações, achando-se, assim, ligadas à infância (...). Já as raças de bronze e dos heróis se vinculam ao vigor físico próprio da idade adulta. A raça de ferro é a única que conhece a degradação da infância para a velhice e a morte." (idem, p. 79)

A partir das considerações acima, podemos compreender melhor o processo de mitologização da infầncia efetuado no poema "Nos áureos tempos", período ao qual o eu poético atribui certas características da idade do ouro. Sublinha ele, porém, que essa infância simbólica não é 'pura', mas sim uma mistura de elementos positivos e negativos, o que gera uma tensão inesperada a esse quadro:

\section{"NOS ÁUREOS TEMPOS}

Nos áureos tempos

a rua era tanta.

O lado direito

retinha os jardins.

5 Neles penetrávamos

indo aparecer

já no esquerdo lado

que em ferros jazia.

Nisto se passava

10 um tempo dez mil.

A viagem do quarto

requeria apenas

a chama da vela.

Que longa, se o rosto

15 fechado no livro.

E dos subterrâneos

a chave era nossa,

como na cascata 
a moça indelével

20 se banhava em nós,

espaço e miragem

se multiplicando

nos áureos tempos.

Nos áureos tempos

25 que eram de cobre

muita noite havia

com chuva soando.

Farto da cidade

um atroz coqueiro

30 ia para o mato.

E vinha o assassino

no pó do correio.

A riqueza da África

se perdia em vento.

35 E era bem difícil

continuar menino.

Chegando ao limite

dos tempos atuais,

eis-nos interditos

40 enquanto prosperam

os jardins da gripe,

os bondes do tédio,

as lojas do pranto.

O espaço é pequeno.

45 Aqui amontoados,

e de mão em mão

um papel circula

em branco e sigilo

talvez o prospecto

50 dos áureos tempos

Nos áureos tempos

que dormem no chão,

prestes a acordar, 
tento descobrir

55 caminhos de longe,

os rios primeiros

e certa confiança

e extrema poesia.

Não me sinto forte

60 o quanto se pede

para interpretá-los.

O jeito é esperar.

Nos áureos tempos

coração-sorriso

65 meus olhos diamante

meus lábios batendo

a alvura de um cântico.

Do arraial trocado

sinto roupas novas

70 e escuto as bandeiras

pelo ar, que se entornam.

Nos áureos tempos

devolve-se a infância

a troco de nada

75 e o espaço reaberto

deixará passar

os menores homens,

as coisas mais frágeis,

uma agulha, a viagem,

80 a tinta da boca,

deixará passar

o óleo das coisas,

deixará passar

a relva dos sábados,

85 deixará passar

minha namorada,

deixará passar

o cão paralítico,

deixará passar 
refletindo o rosto...

Deixará passar

a matéria fosca,

mesmo assim prendendo-a

95

nos áureos tempos."

Na primeira e na terceira estrofes, é explicitado o caráter tensional entre um espaço-tempo de ouro que possibilitava o convívio na "rua" - palavra que, como já dissemos, metaforiza uma noção de coletividade buscada em A Rosa do Povo -, o qual, na realidade, era de cobre, contendo um "esquerdo lado" prostrado em ferros, além de um excesso de noite.

O "esquerdo lado" parece retomar o verso "fatal meu lado esquerdo" de "Consideração do poema", e em ambos os casos podemos compreender a referência a um lugar não apenas lírico como também político. Essa ambivalência é reforçada pela contraposição, na primeira estrofe, entre "O lado direito" que "retinha os jardins", ou seja, uma possível alusão ao ambiente de conservadorismo político dessa época da infância, e o "esquerdo lado / que em ferros jazia".

Vale notar, a propósito, a diferença de posicionamento do adjetivo "esquerdo" em relação ao substantivo "lado" em "Nos áureos tempos" e "Consideração do poema". No primeiro, que se refere ao passado, o adjetivo é anteposto, o que atribui um caráter de maior subjetividade, ou seja, a noção de um estágio ainda gestacional do "esquerdo lado"; e, no segundo, que já diz respeito ao presente, o adjetivo é posposto ("ao fatal meu lado esquerdo"), o que indica a transição para algo mais objetivo e explícito, como o era o "lado direito" durante a infância.

Ao mesmo tempo notamos nas estrofes acima transcritas a camada mitificante do poema. $\mathrm{O}$ verso inicial de ambas, "Nos áureos tempos", remete à idade de ouro, em que não havia dor, conflitos, envelhecimento, morte. Durante essa idade, os homens, ainda jovens, apenas desapareciam enquanto dormissem, sem qualquer sofrimento. Um tempo anterior ao tempo histórico. Por isso nos versos, "Nisto se passava / um tempo dez mil", existe a alusão ao substantivo de origem grega, 'miríade', que corresponde ao número 'dez mil', e o qual é comumente utilizado 
para definir o período da vida de um homem na idade áurea. Mas o interesse da composição reside justamente na mistura de elementos de outras idades do mundo - como a referência explícita à idade do ferro, "que em ferros jazia", e à idade de bronze ou de cobre, "que eram de cobre" -, a qual introduz uma semente de tensão no poema, que, aparentemente, poderia ser lido como uma rememoração pacificada da infância.

Na crônica "Teatro daquele tempo", de Confissões de Minas, referindo-se ao ano de 1910, quando tinha 8 anos, Drummond fala sobre a atmosfera de uma "vida em começo", em sua plena latência de possibilidades. Momento em que frequentava o teatro amador de Itabira, cujos espetáculos o faziam sentir uma espécie de alegria, o que só depois veio a definir como "prazer estético". No texto, há a valorização da experiência dos teatros amadores, cujos atores seriam "pessoas de carne", com as quais o narrador conviveria na cidade, em contraposição às mudanças trazidas pelo progresso, como, por exemplo, o cinema, o automóvel, o colégio interno, a Primeira Guerra Mundial, os quais teriam passado a segregar mais as pessoas. Tanto que na última frase daquela crônica é reafirmada a preciosidade do espaço-tempo da infância: "Tudo o que aconteceu depois, não nego, foi interessante. Mas o bom, mesmo, o gostoso-raro-inesquecível, foi 1910" (DRUMMOND DE ANDRADE. 2011a, p. 144).

Em "Vila de Utopia", crônica publicada pela primeira vez nos jornais A Tribuna e Minas Gerais em 1933, também reunida em Confissões de Minas, fala-se de uma 'inconsciência natural' não só das crianças, mas também dos habitantes de Itabira, como se este estado de dormência lhes possibilitasse uma vida pacífica: "Insisto em dizer que a vida era inconsciente e calma" (idem, p. 120). Mas ao mesmo tempo o narrador define ironicamente esta paralisia itabirana como uma espécie de 'encantamento' a que a cidade está submetida, de modo que os seus moradores “cruzam os braços e deixam a vida passar. A vida passa devagar, em Itabira do Mato Dentro" (idem, p. 121), retomando a noção de "vida besta" do poema "Cidadezinha qualquer", de Alguma poesia. ${ }^{20}$

\footnotetext{
20 "Casas entre bananeiras / mulheres entre laranjeiras / pomar amor cantar. // Um homem vai devagar. / Um cachorro vai devagar. Um burro vai devagar. // Devagar... as janelas olham. // Eta vida besta, meu Deus" ("Cidadezinha qualquer").
} 
Assim, Drummond expõe um conflito entre o reconhecimento do seu vínculo com o passado, por meio do recolhimento e resguardo das memórias de momentos de uma infância prazerosa, e a consciência posterior de que essa experiência era atravessada por aspectos negativos, como a "vida besta", de valores da patriarcalismo, e o fato de que os habitantes de sua cidade natal permaneciam alheios às transformações sociais que ocorriam no mundo. Daí talvez o vínculo com "O lado direito / [que] retinha os jardins".

Na crônica acima citada, parece existir também um questionamento acerca da possibilidade, na infância, de se viver dentro de uma noção de coletividade, como se certas experiências desse período pudessem ser sempre compartilhadas. Pois ao lado de frases com verbos na primeira pessoa do plural, indicando uma atividade coletiva, “mas nós íamos caçar passarinhos ou tomar banho na praia do Rosário, onde uma bica nos dava a impressão de uma catarata doméstica, submetida a nossos desejos. Como foi que a infância passou e nós não vimos?”, (DRUMMOND DE ANDRADE. 2011a, p. 120) segue uma afirmação acerca do caráter individual de tais experiências, "Vinte anos depois, voltando à cidade, não encontrei vestígio algum da aventura individual") (idem, ibidem).

Deste modo, a designação de Itabira como uma "Vila de Utopia" explora de maneira eficaz a ambiguidade do conceito de utopia, não só indicando um espaço-tempo em que se poderia experimentar momentos de prazer, livres de questionamentos e compartilhados com as pessoas na rua, mas também a noção de que esse espaço é um 'não-lugar', ou seja, a noção de que ele só existe por meio dos trabalhos de rememoração e transformação criativa efetuados pelo escritor, na medida mesma em que os demais itabiranos, que não se dispusessem a refletir sobre o passado e o presente, permaneceriam como que adormecidos em relação a suas experiências da infância ou da vida adulta, perpetuando a "vida besta" devagar. Problematiza-se aí, portanto, a questão da inconsciência, que, apesar de ser uma espécie de 'calma', um 'sono', também é tensa e capaz de 
oferecer graves dificuldades àqueles que não optem pelo esforço doloroso da tomada de consciência. $^{21}$

Segundo Michael Hamburger, o que interessa mais à poesia lírica é a consciência que o poeta tem acerca de suas experiências interiores, especialmente aquelas com qualidade epifânica, ficando em segundo plano os acontecimentos exteriores que servem de base à narrativa em verso ou em prosa: “A poesia lírica, por sua própria natureza, sempre esteve menos preocupada com o tempo contínuo, histórico ou épico, com cronos, do que com kairós e o que Joyce chamava de epifanias, momentos em que a experiência ou a visão se concentram ou cristalizam" (HAMBURGER. 2007, p. 86). Acrescenta Hamburger que, para a poesia romântica, essas experiências interiores, convertidas em poemas por um "eu confessional", estão sempre identificadas com o eu empírico do poeta. Já os poetas modernos têm na maioria das vezes se desviado dessa identificação, por já terem consciência da descontinuidade desse eu pessoal, que dificilmente apresenta alguma coerência ao longo do tempo. Buscam, assim, a liberdade de poder ocupar outros corpos, denominados como 'máscaras poéticas'. De todo modo, o crítico finaliza que, mesmo poetas que enfrentaram de maneira mais radical a questão da identidade pessoal - como Valéry, Eliot e Pessoa -, depararam-se sempre com realidades inescapáveis do eu empírico, incorporando-as à sua produção poética, mediadas pelo trabalho transformador da escrita.

No poema "Nos áureos tempos", também é explorada essa ambiguidade, entre o que corresponderia efetivamente à realidade do eu empírico e o modo como esta se teria convertido em matéria poética, perdendo, assim, o caráter confessional e transformando-se em material eminentemente literário. Vale notar que em entrevista a Maria Lucia do Pazo Ferreira, Drummond afirma ter tido "uma infância bastante confusa e triste" (1992, p 339), o que por si só problematiza

\footnotetext{
${ }^{21}$ No poema "Ela canta, pobre ceifeira", Fernando Pessoa expõe esse mesmo impasse entre o desejo de se ter uma vida 'calma' e 'simples', em razão de um estado de "inconsciência”, mas tendo, ao mesmo tempo, consciência da escolha por essa vida: "Ela canta, pobre ceifeira, / Julgando-se feliz talvez; / Canta, e ceifa, e a sua voz, cheia / De alegre e anónima viuvez, // Ondula como um canto de ave / No ar limpo como um limiar, / E há curvas no enredo suave / Do som que ela tem a cantar. // Ouvi-la alegra e entristece, / Na sua voz há o campo e a lida, / E canta como se tivesse / Mais razões para cantar que a vida. // Ah, canta, canta sem razão! / O que em mim sente está pensando. / Derrama no meu coração / A tua incerta voz ondeando! // Ah, poder ser tu, sendo eu! / Ter a tua alegre inconsciência, / E a consciência disso! Ó céu! / Ó campo! Ó canção! A ciência // Pesa tanto e a vida é tão breve! / Entrai por mim dentro! Tornai / Minha alma a vossa sombra leve! / Depois, levando-me, passai!” (PESSOA. 2005. p. 144).
} 
qualquer leitura que se queira fazer acerca de uma identificação entre o eu empírico e o eu poético drummondianos, em que pese a recorrente utilização de material biográfico em sua obra. Assim, o poeta parece explorar o lugar comum do topos poético da infância, em que esta só poderia existir, em sua plenitude, no poema. De todo modo, a maneira pela qual Druumond faz a leitura desse topos, associando-o a uma idade de ouro e definindo a sua cidade natal como uma "Vila de Utopia", ou seja, atribuindo à sua experiência individual uma qualidade universal, acaba por repercutir numa espécie de mitificação da infância. Pois o mito ultrapassa os limites da expressão de uma única individualidade, concentrando, em histórias breves, a experiência imemorial de diversas gerações, cabendo ao poeta retrabalhá-las, em conformidade com o padrão da sua linguagem e com os dados da tradição e do contexto, renovando-as para a compreensão dos leitores de seu tempo, como o explica Werner Jaeger:

"O mito é como um organismo: desenvolve-se, transforma-se e se renova sem cessar. É o poeta que realiza essa transformação. Mas não a realiza em obediência a um simples desejo arbitrário. O poeta estrutura uma nova forma de vida para o seu tempo e interpreta o mito de acordo com as suas novas evidências interiores. O mito só se mantém vivo por meio da contínua metamorfose da sua idéia. Mas a idéia nova é transportada pelo veículo seguro do mito." (JAEGER. 2003, p. 96)

No retrato da infância, o eu lírico diz o quão pouco precisava para realizar viagens pelo mundo, sendo a literatura o veículo para a experiência dessa multiplicidade de lugares:

\footnotetext{
"A viagem do quarto

requeria apenas

a chama da vela.

Que longa, se o rosto

fechado no livro.

E dos subterrâneos

A chave era nossa,
} 
como na cascata

a moça indelével

se banhava em nós,

espaço e miragem

se multiplicando

nos áureos tempos.

Nos áureos tempos

que eram de cobre

muita noite havia

com chuva soando.

Farto da cidade

um atroz coqueiro

ia para o mato.

E vinha o assassino

no pó do correio.

A riqueza da África

se perdia em vento.

E era bem difícil

continuar menino."

Já o processo de abandonar a meninice se dá por meio da conscientização gradativa dos aspectos negativos desse ambiente, como a presença de elementos de violência da idade do cobre; o excesso de "noite", que simboliza o estado de inconsciência dos habitantes da cidade, bem como o contexto rural de fechamento sócio-político. E "o assassino / no pó do correio", que indica a chegada de livros ao poeta (como de fato acontecia àquela época, pelo correio), que iam minando uma visão de mundo infantil. Já a "A riqueza da África / [que] se perdia em vento", talvez se refira tanto à "reza meio africana meio mística" e "que tinha poderes para esconjurar mazelas", ouvida junto a Elias do Casacalho durante a infância ("Vila de Utopia". Confissões de Minas. 2011, p. 123), quanto à "voz severa, mas traindo um secreto carinho, o coração aberto, numeroso..." (idem, 
ibidem), de sá Maria, sua ama-preta, que Drummond chegou a considerar como uma de suas grandes influências literárias. $^{22}$

A ambivalência contraditória dessa fase da sua vida está exemplarmente representada no poema em prosa "Morte de Neco Andrade", de Fazendeiro do Ar (1955), o qual se refere à mesma época da crônica "Teatro daquele tempo", o ano de 1910, quando o poeta tinha oito anos, em que Drummond faz um retrato positivo da sua infância. Neste poema em prosa, o eu lírico mostra como a notícia do assassinato de seu primo, Neco Andrade, influenciou durante a encenação que fazia numa montagem de teatro amador, de modo que o seu papel saísse prejudicado:

“O cadáver de Neco atravessa canhestramente o segundo ato, da esquerda para a direita, volta, hesita, sai, instala-se nos bastidores embaixo da escada. As deixas perdem-se, o diálogo atropela-se, Neco está se esvaindo em silêncio e eu, seu primo, não sei socorrê-lo."

O poema traz ainda a questão da culpa, concentrada no questionamento acerca da moralidade do fato de o eu poético ter se entregado à encenação teatral, a despeito da notícia da morte do primo. E a resposta se dá de maneira surpreendente, na medida em que o eu lírico atribui a si, à sua autoria, a responsabilidade pela morte de Neco e por todo o resto, relativizando, assim, qualquer exigência de veracidade que pudesse ser atribuída a uma composição artística debruçada sobre o passado, ao mesmo tempo que a eleva à condição de uma força geradora de fatos:

\section{"SERIA REMORSO}

por me consagrar ao espetáculo quando já o sabia morto? Não, que o espetáculo é grande, e seduzia para além da ordem moral. (...)

\footnotetext{
${ }^{22}$ Na mencionada entrevista a Maria Lucia do Pazo Ferreira, Drummond afirma que "uma pessoa humilde, a minha ama-preta, foi uma influência na minha vida, influência existencial que se refletiu na literatura, porque tudo influi na gente, a casa onde se nasceu, os móveis, os objetos, os companheiros de infância... Nós somos realmente um cadinho de influências." (PAZO FERREIRA. 1992, p. 332). Além disso, vale notar que em "Vila de Utopia" é dito que sá Maria possui um "coração numeroso", quiçá referindo-se ao poema "Coração numeroso", de Alguma poesia", indicando uma possível influência da relação entre ambos no lirismo explícito desse poema.
} 


\section{E TUDO}

se desvenda: sou responsável pela morte de Neco e pelo crime de Augusto, pelo cavalo que foge e pelo coro de viúvas pranteando. Não posso representar mais; por todo o sempre e antes do nunca sou responsável, responsável, responsável, responsável, responsável.”

A partir do retrato sempre ambíguo da infância drummondiana, é possível pensarmos que Drummond trabalhe sempre a ideia de uma infância simbólica, caracterizada por aspectos positivos de uma vivência prazerosa e de caráter coletivo, na rua, não deixando contudo de expor que essa fase conteria aspectos negativos, especialmente ligados ao contexto da época.

Em estudo acerca de Boitempo (2002), Chantal Castelli explorou a simultaneidade entre recordação e invenção nesse livro memorialístico, demonstrando o modo como a memória reconstitui o passado, e como a criação o transfigura: "as referências à biografia de Drummond são evidentes, embora a matéria do vivido seja transfigurada pela invenção ao ser plasmada na forma poética, a partir da perspectiva do homem maduro, distanciado temporalmente dos eventos de sua infância e primeira juventude" (CASTELLI. 2002, p. 2). Esse mesmo procedimento de rememoração transfigurador do passado existe em "Nos áureos tempos", em cuja quarta estrofe, por exemplo, há a referência explícita "aos tempos atuais", o que materializa a tensão, no poema, entre a idealizada idade do ouro vinculada à memória de uma infância inventada e uma idade do ferro ligada ao presente, onde está completamente reduzido o espaço possível da experiência:

\footnotetext{
"Chegando ao limite

dos tempos atuais

eis-nos interditos

enquanto prosperam

os jardins da gripe,

os bondes do tédio,

as lojas do pranto.

$\mathrm{O}$ espaço é pequeno.

Aqui amontoados,
} 


$$
\begin{aligned}
& \text { e de mão em mão } \\
& \text { um papel circula } \\
& \text { em branco e sigilo, } \\
& \text { talvez o prospecto } \\
& \text { dos áureos tempos.” }
\end{aligned}
$$

Os versos acima contêm imagens que remetem a bloqueio, a espaço fechado, a doenças, a tédio. Tudo o que de certo modo se contrapõe à ideia de "espaço e miragem / se multiplicando / nos áureos tempos", em que há troca entre pessoas na rua, que não se restringisse a lamentações, e jardins que não estivessem infectados, ou seja, a um cotidiano opressor e destituído de sentido. O espaço do presente metaforiza a ‘expulsão do paraíso', e é feita no poema uma leitura crítica acerca dos mitos das idades do mundo e da queda, quando se expõe a decadência do mundo do trabalho, alienante e contrário à natureza humana.

Na obra Infância e História: destruição da experiência e origem da história, Giorgio Agamben fala sobre como o homem moderno e contemporâneo se tornou incapaz de traduzir em experiência os seus atos cotidianos, que eram a matéria prima da experiência que cada geração transmitia à seguinte. Diz ele que a experiência tradicional baseia-se numa noção de 'fundamento', a qual pode ser encontrada, por exemplo, no provérbio ou no mito, mas que ao ser humano de hoje falta a capacidade de atribuir a seus gestos rotineiros qualquer espécie de fundamento, que é traduzido no texto do autor por "autoridade":

"O homem moderno volta para a casa à noitinha extenuado por uma mixórdia de eventos - divertidos ou maçantes, banais ou insólitos, agradáveis ou atrozes - entretanto nenhum deles se torna experiência. (...) Porque a experiência tem o seu necessário correlato não no conhecimento, mas na autoridade, ou seja, na palavra e no conto, e hoje ninguém mais parece dispor de autoridade suficiente para garantir uma experiência, e se dela dispõe, nem ao menos o aflora a idéia de fundamentar em uma experiência a própria autoridade." (AGAMBEN. 2008, p. 22-23) 
Segundo Agamben, na cultura antiga e medieval a fantasia era considerada o meio essencial para o conhecimento, unindo em si o mundo sensível e o mundo do intelecto, de modo que fantasia e experiência possuíssem estatutos semelhantes. Mas com Descartes e o nascimento da ciência moderna, o que havia de subjetivo ou onírico na imaginação passou a ser considerado como material relacionado à loucura, expropriando-se a fantasia da noção de uma experiência autêntica, a qual se tornou exclusivamente vinculada aos processos de uma consciência racional:

“A expropriação da fantasia (...) manifesta-se na nova maneira de caracterizar a sua natureza: enquanto ela não era - no passado - algo de 'subjetivo', mas era, sobretudo, a coincidência entre subjetivo e objetivo, de interno e externo, de sensível e inteligível, agora é o seu caráter combinatório e alucinatório, que a antiguidade relegava ao plano de fundo, a emergir em primeiro plano." (idem, p. 34)

Será que, "Nos áureos tempos", o eu lírico se vale da autoridade do mito para atribuir à infância a qualidade de uma experiência que possa ser efetivamente transmitida? De tal modo, inclusive, para que a própria poesia pudesse ser também resgatada de um pejorativo lugar vinculado à noção de alheamento a um mundo tido por real, e retomasse o estatuto de um meio fundamental para a aquisição de experiência humana? Assim, o que seria esta evocação da infância, como se nela houvesse o material necessário para um revigoramento do fazer poético, dotando-o de um frescor e uma alegria e uma coragem?

\footnotetext{
"Nos áureos tempos

que dormem no chão,

prestes a acordar,

tento descobrir

caminhos de longe,

os rios primeiros

e certa confiança
} 
e extrema poesia.

Não me sinto forte

o quanto se pede

para interpretá-los

O jeito é esperar.”

De acordo com Agamben, tanto a experiência quanto a infância se caracterizam como o limite da linguagem, ou seja, a diferença entre o humano e o linguístico, de modo que este se torna impossibilitado de mostrar-se como totalidade e verdade, na medida em que existe uma experiência humana originária, cuja expropriação é realizada, depois, pelo surgimento do sujeito do discurso. De todo modo, a esfera da infância, como limite transcendental da linguagem, acaba por constitui-la como lugar da verdade:

"O inefável é, na realidade, infância. A experiência é o mystérion que todo homem institui pelo fato de ter uma infância. Este mistério não é o juramento de silêncio e de inefabilidade mística; é, ao contrário, o voto que empenha o homem com a palavra e a verdade. Assim como a infância destina a linguagem à verdade, também a linguagem constitui a verdade como destino da experiência. A verdade não é, por isso, algo que possa ser definido no interior da linguagem, mas nem mesmo fora dela, como um estado de fato ou como uma 'adequação' entre este e a linguagem: infância, verdade e linguagem limitam-se e constituem-se um ao outro em uma relação original e histórico-transcendental no sentido que se viu." (AGAMBEN. 2008, p. 63)

A partir daí é possível pensar se, no poema ora analisado, o ato de evocação da infância não implica numa espécie de comprometimento do sujeito poético não só com as palavras, mas ainda com uma noção de verdade de natureza humana, de modo que àquele primeiro 'pacto com as palavras', ou seja, com o universo da linguagem mencionado na análise de "Procura da poesia", fosse adicionado um elemento vinculado à experiência, à infância, cujo "prospecto" estaria ainda em processo de cognição. 
Nas duas estrofes finais de "Nos áureos tempos", a invocação da infância adquire um tom de reza, como se o eu lírico estivesse adentrando de vez na atmosfera infantil, retornando ao lugar onde haveria alguma espécie de festa religiosa, como a de São João, num arraial com bandeiras. E, por meio de um ritual, com "coração sorriso", "meus olhos diamante", "meus lábios batendo", entoando a "alvura de um cântico", a repetir sempre o mesmo verso anunciativo, "deixará passar", é reaberto um túnel para a comunicação dos elementos divinos daquele passado, cuja existência passa a ser projetada num futuro utópico, que incorporasse as qualidades dos 'áureos tempos':

\footnotetext{
"Nos áureos tempos

coração sorriso,

meus olhos diamante

meus lábios batendo

a alvura de um cântico.

Do arraial trocado

sinto roupas novas

e escuto as bandeiras

pelo ar, que se entornam.
}

Nos áureos tempos

devolve-se a infância

a troco de nada

e o espaço reaberto

deixará passar

os menores homens,

as coisas mais frágeis,

uma agulha, a viagem,

a tinta da boca,

deixará passar

a relva dos sábados,

deixará passar

minha namorada,

deixará passar

o cão paralítico,

deixará passar 
o círculo da água

refletindo o rosto...

Deixará passar

a matéria fosca,

mesmo assim prendendo-a

nos áureos tempos.”

O ritmo e a tonalidade de um cântico podem ser notados especialmente na última e mais extensa estrofe, em que a repetição dos mesmos versos em redondilha menor, “deixará passar", dá a impressão de que o eu lírico estivesse dentro de uma romaria - que é também sinônimo de arraial, no sentido de festa popular de caráter religioso -, entoando, à maneira do "Cântico das subidas" (Salmos 120-134), hinos de passagem desses ‘áureos tempos’.

Neste sentido, vale notar que na crônica "Número 10 mil", que já havia sido publicada em 1932 no jornal Minas Gerais, antes de ser reunida em Confissões de Minas, Drummond discorre acerca da necessidade de se saber discar ao telefone o número 10 mil, para que lhe seja oferecida " $a$ voz mais harmoniosa que já se ouviu desde a aurora do mundo" (DRUMMOND DE ANDRADE. 2011a, p. 213). Ou seja, o autor refere-se ao mesmo número contido no verso 10 de "Nos áureos tempos" - "um tempo dez mil" -, o qual se refere a "miríade". Por meio dessa voz, o indivíduo seria tomado por inúmeros pensamentos anteriores e superiores aos de sua medíocre vida atual, como, por exemplo, “O gosto de ficar rezando ou lembrando-se das rezas decoradas na infância, quando o incenso e a ladainha lenta das novenas faziam a igreja próxima de sua casa desprender-se da âncora e subir e navegar por mares de bruma" (idem, ibidem). E reconheceria as 'coisas boas' que fazem parte da essência dessa voz, como "a doçura da sombra das árvores, o gorgolejo das águas que escorrem mato afora e não banham corpos humanos, o manso compasso das horas na casa fechada, o gosto do pão, o da poesia que não se lê nos jornais" (idem, p. 214).

Assim, é evidente o paralelo temático entre o poema "Nos áureos tempos" e a crônica mencionada acima, de modo que a procura pelo "número 10 mil" e por tudo que ele significa, parece simbolizar, em ambos os textos, uma via de acesso ao lugar de uma infância simbólica, em 
que os rituais religiosos estariam presentes de modo determinante, possibilitando uma espécie de transcendência em relação ao presente degradado, percepção que, em Claro Enigma, Drummond vem a repetir por meio do poema "Evocação Mariana", ao descrever a missa numa igreja dessa cidade. $^{23}$

Note-se também a semelhança entre as imagens finais de "Nos áureos tempos" e da crônica de Confissões de Minas, ambos referindo-se a pequenos seres e coisas frágeis e a simples eventos de uma rotina comum - "os menores homens", "uma agulha", "a tinta da boca", "a relva dos sábados", "o gosto do pão", "os encontros inesperados" -, como se os textos tivessem a intenção de reabrir ao sujeito o espaço da infância, de modo que todo esse universo reassumisse o estatuto de um lugar de experiência humana. Já em "Vida menor", como veremos no próximo tópico deste capítulo, a ideia de aproximação com um universo miniaturizado pode ser lida sob uma chave estóica, enquanto resignação estratégica face a um mundo caótico.

Quanto ao caráter profético do poema, nota-se que "Nos áureos tempos" há uma flutuação de tempos verbais, começando pelo pretérito imperfeito nas três primeiras estrofes, flexionando para o presente nas três estrofes seguintes, encontrando-se, na última, a maioria dos verbos no futuro, ${ }^{24}$ o que parece indicar inclusive um discurso escatológico baseado numa visão circular de mundo, que estaria antecipando o final de um ciclo que se encontraria já em sua etapa final, ou seja, na idade do ferro, para reingressar numa idade do ouro. Essa visão cíclica, aliás, se assemelha à da alquimia tradicional, que se opõe à concepção moderna de um progresso indefinido, como o diz Serge Hutin: "é no passado, na origem do ciclo terrestre, que está situada a Idade do Ouro. Mas é verdade que, no fim extremo da involução teria início um novo ciclo, com uma nova idade de ouro" (HUTIN. 1999, p. 180). Não há, de todo modo, uma ordenação progressiva linear no tempo cíclico;

\footnotetext{
23 "De seu peso terrestre a nave libertada, / como do tempo atroz imunes nossas almas, / flutuávamos / no canto matinal, sobre a treva do vale" ("Evocação Mariana").

${ }^{24}$ Não por acaso, essa mesma flutuação verbal pode ser vista no poema Os trabalhos e os dias, conforme o comentário de sua tradutora, Mary de Camargo Neves Lafer: "Uma flutuação entre verbos no presente e no futuro se dá até o v. 179, para em seguida aparecerem todos no tempo futuro, caracterizando o tom profético do texto." (HESÍODO. 2008, p. 86).
} 
mas sim um movimento de flutuações, e o retorno de uma idade de ouro pode vir naturalmente atravessado por elementos de outras idades.

É possível verificar ainda, nessa projeção de uma nova idade áurea, a dimensão românticorevolucionária do marxismo, que, segundo Michel Löwy, buscaria nos valores comunitários de um passado pré-capitalista, substrato para enriquecimento da perspectiva socialista futura: “A idade de ouro do passado que ilumina o caminho para o futuro: dificilmente se poderia imaginar uma fórmula mais feliz, mais precisa e mais surpreendente para resumir a Weltanschauung romântica revolucionária, pela qual Lukács manifesta aqui uma inegável afinidade e simpatia" (LÖWY. 1990, p. 30). ${ }^{25}$

Por outro lado, a partir da quinta estrofe de "Nos áureos tempos", deixa-se de utilizar verbos e pronomes no plural ("penetrávamos", "nossa", "nós", "eis-nos"), passando a conjugá-los na primeira pessoa do singular ("tento descobrir", "Não me sinto forte", "meus olhos", "meus lábios"), indicando um processo de individuação do sujeito poético ao longo do poema, o qual passa a reconhecer tanto suas carências quanto as da coletividade, na medida em que a projeção, no futuro, diz respeito ao ressurgimento, na terra, de uma nova idade áurea, em que sujeito e coletividade possam reexperimentar os elementos de uma infância simbólica, superando o momento histórico de negatividade.

Assim, o poema adquire um caráter eminentemente utópico, conforme a definição de Hilário Franco Junior, para quem: “A utopia é nostálgica, busca a harmonia edênica, é portanto um mito projetado no futuro." (FRANCO JR. 1992, p. 12-13). Mas por valer-se da estrutura ambivalente e escorregadia do mito, vinculando-a a uma concepção complexa da infância, simultaneamente positiva como um espaço-tempo inviolável, mas negativa por já estar impregnada pelo tempo histórico, a projeção utópica de inversão do curso da história para um regresso da idade do ouro,

\footnotetext{
${ }^{25} \mathrm{Na}$ obra A estética do Romantismo, Paolo d'Angelo sublinha os aspectos utópicos do primeiro romantismo, mas ressalva também os seus tons dissonantes, como a tendência para uma espécie de "niilismo", expressão que teria tido as suas primeiras ocorrências na época romântica: "O tema da 'nova mitologia' levou-nos a acentuar os aspectos utópicos do primeiro romantismo, a confiança por ele manifestada pela 'idade do ouro que está para vir', para usar as últimas palavras do discurso schlegeliano. Mas no romantismo, e também no primeiro romantismo, não há apenas tons sonantes, expectativas cheias de fé, ímpetos revolucionários, não se considera a história exclusivamente como uma palingenesia." (D’ANGELO. 1998, p. 87).
} 
acaba por tornar-se uma mistura entre esperança e incredulidade, refletida na relação antitética existente entre os poemas de A Rosa do Povo, oscilante entre claridade e noite, entre o anúncio de uma possível plenitude de sentido da história e a expressão do completo absurdo do mundo, onde a violência se encontra institucionalizada no cotidiano.

\subsection{Utopia da vida mínima: "Vida menor" e "Campo, chinês e sono"}

"É nos jardins do minúsculo que o poeta conhece o germe das flores.” (BACHELARD. 2012, p. 170)

"Vida menor" integra o conjunto dos poemas da obra de 45 marcados pelo "fechamento do discurso poético", como notou Iumna Simon em seu estudo sobre o livro. ${ }^{26}$ E, como se vê, o movimento contido no poema rompe com qualquer possível leitura linear acerca de um sujeito lírico que, através dos poemas de A Rosa do Povo, se deslocasse sempre em busca de uma participação em meio à coletividade, metaforizada pela imagem do caminhar ao lado de pessoas, na rua:

\section{"VIDA MENOR}

A fuga do real

ainda mais longe a fuga do feérico,

mais longe de tudo, a fuga de si mesmo,

a fuga da fuga, o exílio

5 sem água e palavra, a perda

voluntária de amor e memória,

o eco

\footnotetext{
${ }^{26}$ Dentre esses poemas, citamos poemas paradigmáticos como "Rola mundo", "O poeta escolhe seu túmulo", "Campo, chinês e sono", "Episódio", "Nova canção do exílio", "Economia dos mares terrestres", "Equívoco", "Movimento da espada".
} 
já não correspondendo ao apelo, e este fundindo-se,

a mão tornando-se enorme e desaparecendo

10

desfigurada, todos os gestos afinal impossíveis,

senão inúteis,

a desnecessidade do canto, a limpeza

da cor, nem braço a mover-se nem unha crescendo.

Não a morte, contudo.

15 Mas a vida: captada em sua forma irredutível,

já sem ornato ou comentário melódico,

vida a que aspiramos como paz no cansaço

(não a morte),

vida mínima, essencial; um início; um sono;

20

menos que terra, sem calor; sem ciência nem ironia;

o que se possa desejar de menos cruel: vida

em que o ar, não respirado, mas me envolva;

nenhum gasto de tecidos; ausência deles;

confusão entre manhã e tarde, já sem dor,

25 porque o tempo não mais se divide em seções; o tempo

elidido, domado.

Não o morto nem o eterno ou o divino,

apenas o vivo, o pequenino, calado, indiferente

e solitário vivo.

$30 \quad$ Isso eu procuro."

Há aqui um desejo de evasão de todas as instâncias contextualizantes, a saber, do presente histórico, da imaginação, da consciência, da poesia, como se esse exílio possibilitasse um estado vital diminuto, completamente subjugado ao controle do eu poético; espécie de "paz no cansaço", em que não houvesse mais a consciência de um mundo complexo e angustioso. Mas a palavra utilizada já no verso inicial e repetida quatro vezes na primeira estrofe, é "fuga".

Podemos questionar já de início se esse gesto de recolhimento do eu lírico, a um lugar intemporal e solitário, indicaria alguma espécie de niilismo, ou seja, se haveria uma total recusa aos propósitos de engajamento enunciados em poemas anteriores como "Nosso tempo", prevalecendo uma visão de mundo de que a vida pudesse ser vivida na sua mais completa solidão, independente 
da adaptação do indivíduo a qualquer grupo social. Mas, conforme o próprio Drummond sublinha na crônica "Fagundes Varela, solitário imperfeito", de Confissões de Minas, a solidão absoluta, de caráter niilista, deriva de um sentimento súbito que assolasse o sujeito em meio à vida moderna, deixando-o completamente indiferente às questões sociais, mas ao mesmo tempo angustiado com esse estado de solipsismo:

“A solidão é niilista. Penso numa solidão total e secreta, de que a vida moderna parece guardar a fórmula, pois para senti-la não é preciso fugir para Goiás ou as cavernas. No formigamento das grandes cidades, entre os roncos dos motores e o barulho dos pés e das vozes, o homem pode ser invadido bruscamente por uma terrível solidão, que o paralisa e o priva de qualquer sentimento de fraternidade ou temor. Um desligamento absoluto de todo compromisso liberta mas ao mesmo tempo oprime a personalidade." (DRUMMOND DE ANDRADE. 2011a, p. 28) ${ }^{27}$

A noção drummondiana de niilismo não só afasta a necessidade de exílio a um lugar ermo, como também exclui qualquer ato de deliberação, já que, para sentir a 'solidão niilista', o sujeito seria assolado por uma paixão negativa, contra a sua vontade. Em "Vida menor", não há niilismo, pois o gesto do eu poético é inteiramente voluntário, e essa procura por uma experiência essencial não esclarece se há nela, também, um desejo de abandono irrevogável dos compromissos de

\footnotetext{
${ }^{27}$ Tal crônica situa-se na primeira seção de Confissões de Minas, denominada "Três poetas românticos", e antecede a seção "Na rua, com os homens". E a palavra "niilismo" parece ter sido utilizada nela de modo bastante refletido, na medida em que essa expressão, apesar de remete-se a Nietzsche e ao romance Pais e Filhos (1862) de Turguénev, teve origem na época romântica, como o diz Paolo d'Angelo em A Estética do Romantismo: "é certo que as primeiras ocorrências do nome [niilismo] e da coisa remontam precisamente à época romântica" (D’ANGELO. 1998, p. 87). Além de apresentar aspectos utópicos revolucionários, como a crença de que uma nova idade do ouro estaria prestes a surgir, o romantismo se caracteriza também por atitudes niilistas, "nas quais a obscuridade e a noite tomam o lugar da luz, o desespero o da esperança, a incredulidade o da fé, e em vez de anunciar a plenitude de sentido da história dá-se expressão à pura insensatez do mundo" (idem, ibidem). Drummond estaria refletindo sobre a conservação de algumas características do espírito romântico na modernidade? Haveria elos de continuidade e pontos de ruptura no registro de aspectos dessas correntes literárias em A Rosa do Povo, cuja gênese parece estar elaborada em Confissões de Minas? De um lado, vê-se uma certa atração drummondiana por uma espécie de 'dissolução na noite', tal qual preconizada por Novalis; um gesto de completa negatividade em relação ao mundo exterior, no qual o poeta se sentiria inadequado. De outro lado, nota-se uma atitude afirmativa do sujeito poético no que diz respeito à relevância da vida na sua materialidade cotidiana, de modo a recusar a ideia de soberania de um 'eu ilimitado' transcendente, típico ao romantismo, o qual seria juntamente o contrário da sentença contida nestes versos de "Consideração do poema": "Poeta do finito e da matéria, / cantor sem piedade, sim, sem frágeis lágrimas".
} 
engajamento e de uma completa resignação a um destino solitário. Aliada ao sentido da palavra fuga enquanto 'retirada estratégica', não indicaria, antes, uma pausa para 'depuração' do poema e do sujeito, tentando remover com isso "todo elemento de brilho e sedução formal (coisa espetacular), como todo resíduo sentimental (coisa comovedora), para que somente o essencial permanecesse", como se lê no texto "A coisa simples" de Confissões de Minas? ${ }^{28}$

Assim, perguntamos se no poema não há inclusive uma reflexão metapoética acerca da complexidade do gesto de buscar a simplicidade e, consequentemente, a beleza na arte, mesmo porque no referido texto em prosa, Drummond afirma que "a coisa bela é simples por depuração" (idem, ibidem), lembrando que a "poesia mais rica / é um sinal de menos", como se lê em "Poema orelha" de A vida passada a limpo (1959).

Nesse sentido, vale notar a simplicidade do vocabulário e da estrutura sintática de "Vida menor", que apresenta dicção coloquial, sem descartar o uso do discurso com nexos sintáticos, situando-se, talvez, o seu caráter aparentemente hermético na alusão a um estado vital originário e mudo, existente em um (não) lugar atemporal, que não se refere à morte, nem propriamente a um lugar que remeta a uma ideia de sagrado ("Não o morto nem o eterno ou o divino").

De acordo com Agamben, o homem se constitui enquanto sujeito na linguagem e por meio da linguagem, na medida em que adquire uma 'realidade de discurso', a partir do momento em que passa a utilizar o sistema dos indicadores de elocução, tais como os pronomes pessoais. Segundo ele, uma consciência que desejasse refletir de maneira verdadeiramente radical acerca da origem da experiência humana e da linguagem, deveria partir da indagação da existência de uma "experiência pura e por assim dizer ainda muda", ou seja, anterior à constituição do sujeito:

"Dado que, se o sujeito é simplesmente o locutor, nós jamais apreenderemos no sujeito, como Husserl acreditava, o estatuto original da experiência, 'a experiência pura e, por assim dizer, ainda muda'. Ao contrário, a constituição do sujeito na linguagem e através da linguagem é precisamente a expropriação desta experiência 'muda', é, portanto, já sempre

\footnotetext{
${ }^{28}$ DRUMMOND DE ANDRADE. 2011a, p. 197.
} 
'palavra'. Uma experiência originária, portanto, longe de ser algo subjetivo, não poderia ser nada além daquilo que, no homem, está antes do sujeito, vale dizer, antes da linguagem: uma experiência 'muda' no sentido literal do termo, uma in-fância do homem, da qual a linguagem deveria, precisamente, assinalar o limite." (2008, p. 58)

Toda a elocução de "Vida menor" parece indicar a procura por essa experiência ainda "muda" e anterior à linguagem, um gesto de radicalidade que, como dissemos, indicaria uma completa recusa a uma noção de experiência mundana dentro de um presente histórico, e até mesmo uma negação da própria função social do ofício poético: “todos os gestos afinal impossíveis, / senão inúteis, / a desnecessidade do canto (...) Não a morte, contudo". Mas o que se pode pensar acerca desse gesto paradoxal de se negar a existência no tempo, e ainda continuar vivo?

Ao analisar o poema "Campo de flores", de Claro Enigma, João Luiz Lafetá enfrentou questão semelhante, dizendo que a ideia de superação do tempo, a despeito da morte, como se lê nos versos "Para fora do tempo arrasto meus despojos / e estou vivo na luz que baixa e me confunde", é uma afirmação da essência: “Ora, superar o tempo é superar a própria existência - já que, contingentes, nós somos no tempo - e com a existência todos os conflitos. Mas, simultaneamente, suprimir o tempo significa assumir a essência, abandonar o devir e atingir o Ser.” (LAFETÁ. 2004, p. 54). Para Lafetá, o fato de essa contradição ter sido expressa no poema, indica já uma espécie de 'posse' e 'superação' do paradoxo de suprimir-se a existência, conservando-se vivo.

Outro ponto abordado pelo crítico consiste na análise sintática de "Campo de flores", e o que chama atenção nessa leitura específica é a observação de que o "uso lógico da linguagem, apoiada na sintaxe, denuncia, como consequência que é, a presença de uma objetividade que não foi completamente interiorizada" (idem, p. 43). Em "Vida menor", como dissemos, o pensamento assume a forma discursiva, baseando-se nos processos básicos da sintaxe de subordinação e coordenação, o que revela, também, a presença de uma situação objetiva cuja interiorização é ainda almejada pelo eu lírico. Note-se, por exemplo, que a utilização reiterada do advérbio “já” remete 
sempre a um instante futuro ("já não correspondendo ao apelo", "já sem ornato ou comentário melódico", "já sem dor"), o que é reforçado de maneira categórica pelo verso final, "Isso eu procuro". Assim, conforme a denominação de Wolfgang Kayser acerca das atitudes líricas (1968), que serviu de base para a análise de Lafetá, a atitude do sujeito poético de "Vida menor" é a da "enunciação", na medida em que ainda se posta à frente de um acontecimento, buscando apreendêlo e exprimi-lo, diferentemente da atitude lírica da "canção", em que a objetividade está completamente amalgamada à subjetividade do eu.

Para melhor compreender essa busca por uma "essência", por um "Ser" fora do tempo, é interessante trazer ainda a reflexão de Gaston Bachelard sobre a noção literária da "miniatura". Segundo ele, através do procedimento 'miniaturizante', o escritor tenta furtar-se à opressão de um mundo grandioso, voltando-se para o universo de uma realidade imaginária em escala diminuta, submetida ao seu controle, resistindo assim ao processo de dissolução do mundo exterior, operado a partir da sua interioridade convertida em escrita dissolvente:

“As fórmulas 'ser-no-mundo', 'o ser do Mundo' são excessivamente majestosas para mim; não consigo vivê-las. Fico mais à vontade nos mundos da miniatura. São para mim mundos dominados. Vivendo-os, sinto a partir de meu ser sonhador ondas mundificadoras. A enormidade do mundo é para mim apenas o emaranhamento das ondas mundificadoras. A miniatura sinceramente vivenciada desprende-me do mundo ambiente, ajuda-me a resistir à dissolução do ambiente. (...) E que repouso em tal exercício de mundo dominado! A miniatura é repousante, sem jamais fazer adormecer. A imaginação permanece vigilante e feliz." (BACHELARD. 2012, p. 168)

Bachelard compreende que a miniatura é um produto da depuração efetuada pelo escritor, em que os valores se condensam e se enriquecem, tornando-se uma espécie de "ninho de solidão", semente de onde brotará uma nova visão de mundo. A partir daí, questionamos se a procura por um organismo mínimo e atemporal, enunciada em "Vida menor", não faz parte de todo um processo de gestação da "rosa" elaborado ao longo da obra de 45, o qual envolve uma fase de 'depuração' ou 
'destilação', mesmo porque, citando ainda Bachelard, seria "nos jardins do minúsculo que o poeta conhece o germe das flores." (idem, p. 170). ${ }^{29}$ Nesse sentido, vale notar que, logo após a série de poemas de caráter mais fechado ou até "miniaturizante" do livro, se situa o poema "Anúncio da rosa", que, de certo modo, configura um ponto de inflexão de A Rosa do Povo, a partir do qual a visão do sujeito poético parece espraiar-se mais por temas da coletividade, podendo sugerir que essa flor complexa, ainda em botão, teria germinado de um contato com a substância mais interior e condensada do sujeito poético.

Por isso também é possível questionar o que estaria a sugerir a enunciação de uma "fuga do real", já no primeiro verso de "Vida menor". Inicialmente, como dissemos, a elocução daria a entender que o eu lírico estivesse em busca de uma espécie de evasão niilista, que redundasse num descompromisso completo com os ideais de engajamento; um encontro com o 'Ser' por meio da elisão do tempo histórico. Mas é ainda possível imaginar se esse desejo de fuga não teria antes um caráter político utópico de negação do contexto do progresso capitalista; de recusa de um processo ideológico de massificação dos valores e gestos cotidianos, por meio da alusão a um exílio literário em que se pudesse ter pleno controle e liberdade, e que contivesse o germe da "cidade futura", como aliás sugeriu Drummond na crônica "Divagação sobre as ilhas" de Passeios na ilha, publicado já durante a transição da poética de A Rosa do Povo para a de Claro Enigma: ${ }^{30}$

"A ideia de fuga tem sido alvo de crítica severa e indiscriminada nos últimos anos, como se fosse ignominioso, por exemplo, fugir de um perigo, de um sofrimento, de uma caceteação. Como se devesse o homem consumir-se numa fogueira perene, sem carinho para com as partes cândidas ou pueris dele mesmo, que cumpre preservar principalmente em vista de uma possível felicidade coletivista no futuro. (...) Estas reflexões descosidas procuram

\footnotetext{
${ }^{29}$ Ao tratar do processo alquímico, Ernst Bloch fala sobre a necessidade do candidato a adepto passar por um processo de simplificação de si mesmo, para alcançar a 'essência': “demandava-se do candidato a adepto a 'henosis', expressão neoplatônica que significa simplificação de si próprio, concentração na força eficaz e na semente” (BLOCH. 2006a, p. 194).

${ }^{30}$ Os textos de Passeios na ilha ainda são de grande valia para auxílio no esclarecimento de poemas fechados do livro de 45, dado o deslizar de temas tratados ora nos textos em prosa, ora na poesia drummondiana, por inexistir, a partir de Sentimento do mundo, um delineamento preciso, em cada poema, acerca das características de um gênero literário específico, os quais passaram a ser utilizados de maneira ampla e misturada, sendo possível defini-los sob a categoria de "textos".
} 
apenas recordar que há motivos para ir às ilhas, quando menos para não participar de crimes e equívocos mentais generalizados. São motivos éticos, tão respeitáveis quanto os que impelem à ação o temperamento sôfrego.” (DRUMMOND DE ANDRADE. 2011b, p. 19)

Apesar de o trecho acima ter sido escrito num momento em que Drummond já passava por um processo de desilusão, no tocante à viabilidade de materialização dos ideais e valores socialistas, especialmente devido à sua frustração quanto ao modo autoritário por que o Partido Comunista Brasileiro vinha impondo a sua cartilha ideológica aos correligionários, o princípio ético parece ser o mesmo de "Vida menor". É como se a necessidade de resguardo de uma noção autêntica de individualidade, enquanto gesto de negatividade face ao contexto histórico, acabasse por adquirir efetiva qualidade política a partir do momento em que se venha a converter em matéria textual.

Vê-se aí, portanto, a mistura entre as noções de busca por uma experiência anterior à linguagem e à constituição do sujeito; de metamorfose miniaturizante do eu num organismo mínimo, essencial, pelo qual se alcançaria o controle da vida angustiosa e a sujeição da existência, até então inserida na continuidade do tempo histórico; de depuração para alcançar a "coisa simples", ou seja, para achar uma espécie de semente da obra em gestação; de negatividade intransigente em relação ao contexto capitalista, mediante a fuga deliberada para o espaço da imaginação livre e autônoma, movimento que visa a destruir valores mercadológicos emaranhados em modos de sentir, em palavras, em coisas.

Considerando ainda o compromisso drummondiano com o 'finito e com a matéria', pode-se pensar numa certa 'fuga relativa' proposta pelo sujeito lírico, isto é, uma evasão que nunca estaria completamente pacificada, porque permaneceria sempre inscrita na história, apesar de muitas vezes os poemas dizerem aparentemente o contrário, transmitindo a impressão de que a "fuga do real" se teria consumado no desenho da realidade imaginada. Em "Nova canção do exílio", por exemplo, identificamos o sabiá exilado com o próprio sujeito poético; porém, o verbo predicativo "ser" é conjugado sempre no futuro do pretérito, indicando algo que poderia ser, mas não é: 


\author{
"Só, na noite, \\ seria feliz: \\ um sabiá, \\ na palmeira, longe. \\ Onde é tudo belo \\ e fantástico, \\ só, na noite, \\ seria feliz. \\ (Um sabiá, \\ na palmeira, longe.)"
}

O exílio distante é desmaterializado e, portanto, utópico, um 'não-lugar' existente apenas na esfera da idealização. Para melhor explicá-lo, retomamos a noção de Gaston Bachelard acerca da miniatura. Este diz que o escritor mergulha no minúsculo buscando um país onde gostaria de viver, já que nas miniaturas do longínquo, as coisas díspares viriam a se compor, oferecendo-se harmonicamente à posse do sonhador que, no longe, as receberia com tranquilidade: “Aliás, $o$ longínquo forja miniaturas em todos os pontos do horizonte. Diante desses espetáculos da natureza distante, o sonhador destaca essas miniaturas como ninhos de solidão onde sonha viver" (BACHELARD. 2012, p. 178).

Isto é como uma 'meditação', pela qual o escritor se desprende de um ambiente agitado, proporcionando a si uma sensação de controle. Quando, porém, a solidão é especificada por meio de imagens concretas, sublinhando a banalidade da construção fantasiosa - no poema acima, isto se dá por meio da inversão de sentido de "Canção do exílio" de Gonçalves Dias, ressaltando o desejo do sujeito poético, convertido na imagem do sabiá, de permanecer na noite exilado -, entende Bachelard que é esta uma espécie de "solidão aberta", isolada no longínquo, mas ainda afetada pelo contato com os homens, já que "A solidão fechada teria outros pensamentos. Negaria o mundo de outra maneira. Não teria, para dominá-lo, uma imagem concreta" (idem, p. 179). 
De acordo com Bachelard, a miniatura decorre, a princípio, exclusivamente das imagens da visão. Mas ele mesmo relativiza esse ponto de vista, ao dizer que o poeta atento à "palavra interior" é capaz de criar também uma espécie de "miniatura sonora", relativa a "todo um cosmo que fala baixo" (idem, p. 181), na e pela qual falariam as cores e as formas. A intenção do criador dessa miniatura é a de convidar o leitor a tomar consciência dos menores sinais contidos nas coisas, ensinando-o a 'escutar' o que aparentemente não pode falar e, enfim, a penetrar num mundo de silêncio, que aponta para uma noção de 'origem':

"deveríamos meditar longamente sobre um mundo que existe em profundidade por sua sonoridade, um mundo cuja existência toda seria a existência das vozes. A voz, ser frágil e efêmero, pode testemunhar as mais fortes realidades. Ela assume (...) as certezas de uma realidade que une o homem e o mundo. Mas antes de falar é preciso ouvir.” (idem, p. 185)

No poema "Campo, chinês e sono", após a descrição de uma paisagem de caráter imemorial, em que inicialmente o campo se confunde com a imagem de um chinês dormindo, para depois enunciar uma diferenciação entre essas duas imagens, de todo modo ainda herméticas, o leitor ou o próprio sujeito poético é interpelado, ao final, a debruçar-se no sentido da audição, para ouvir os ruídos do sono, da terra, das nuvens, como se um ouvido atento ao silêncio lhe possibilitasse a penetrar no mistério da paisagem, permitindo-lhe enxergar e compreender a natureza, enquanto fonte geradora de uma forma humana:

\section{“CAMPO, CHINÊS E SONO}

O chinês deitado

no campo. O campo é azul,

roxo também. O campo,

o mundo e todas as coisas

5 têm ar de um chinês

deitado e que dorme. 


Como saber se está sonhando?
O sono é perfeito. Formigas
crescem, estrelas latejam,
peixes são fluidos.
E árvores dizem qualquer coisa
que não entendes. Há um chinês
dormindo no campo. Há um campo
cheio de sono e antigas confidências.
Debruça-te no ouvido, ouve o murmúrio
do sono em marcha. Ouve a terra, as nuvens.
O campo está dormindo e forma um chinês
de suave rosto inclinado
no vão do tempo.”

Diferentemente da estrutura sintática de "Vida menor", sustentada por nexos sintáticos subordinativos que evidenciam um pensamento discursivo e configuram, conforme diz Kayser, uma 'atitude lírica enunciativa', em que a subjetividade do eu lírico permanece ainda dissociada do ser objetivo que se tenta apreender pelo discurso, no poema acima prevalece a sintaxe da coordenação, na qual há a justaposição de versos, em que se vão somando gradativamente as imagens, formandose, pelo acréscimo sucessivo de novas camadas, um quadro mais complexo acerca da paisagem. E a atitude poética parece ser a de 'apóstrofe lírica', na medida em que as esferas subjetiva e objetiva não são postas em situação de confronto, mas sim sobrepostas entre si, como se o sujeito poético já estivesse dentro do quadro em movimento, mas necessitasse ainda do auxílio dos sentidos para compreendê-lo.

O poema "Campo, chinês e sono" foi publicado pela primeira vez na revista carioca Esfera, em 1944, sendo dedicado a João Cabral de Melo Neto, que até então publicara a coletânea de poemas Pedra do sono, em 1942, e o poema "Os três mal amados", em 1943. O primeiro livro de Cabral contém fortes características surrealistas, explorando o limiar entre o inconsciente e a vigília, com o delineamento de atmosferas oníricas repletas de silêncios, como nestes versos de "Homem 
falando no escuro": "Dentro da noite ao meu lado / grandes contemplações silenciosas; / dentro da noite, dentro do sonho / onde os espaços e o silêncio se confundem" (MELO NETO. 1994, p. 49). Já no referido poema de Drummond é feita a pergunta “Como saber se está sonhando?”, já que “ $O$ sono é perfeito". E talvez para respondê-la, o poeta tenha trazido a figura de um chinês, cuja cultura oriental parece conter reflexões interessantes para a compreensão da relação entre os mundos da matéria e da consciência com os sonhos.

Segundo Carl Gustav Jung, o homem ocidental está limitado a uma relação exterior com o eu e o objeto, desconhecendo as raízes profundas que ligam o "ser" ao "fundamento originário", ao passo que o oriental apresenta uma postura inversa, vivendo sem mediações o seu inconsciente:

"o homem oriental vivencia o mundo das coisas particulares e o seu próprio eu como um sonho, pelo fato de seu ser encontrar-se enraizado no fundamento originário; este o atrai de forma tão poderosa que relativiza sua relação com o mundo, de um modo muitas vezes incompreensível para nós. A atitude ocidental - que dá ênfase ao objeto - tende a relegar o 'modelo' de Cristo a ser aspecto objetal, roubando-lhe a misteriosa relação com o homem interior". (JUNG. 2011a, p. 20)

Para Jung, o inconsciente é uma espécie de ligação do homem com o mistério da "origem", e o gesto de entrar em contato com os sonhos e transpor a sua substância à consciência é um modo de transformação do ser humano, que, a partir daí, deixa de vivenciar o "arquétipo da imagem de Deus" de maneira apenas exterior, ou seja, recebendo-o como modelo de fora para dentro, para experimentá-lo a partir da sua interioridade.

Ou seja, o homem ocidental permaneceria à espera da graça de um ser superior e divino, enquanto o oriental teria a consciência de que a redenção depende da sua própria obra individual. No livro O segredo da flor de ouro: um livro de vida chinês, de C. G. Jung e Richard Wilhelm, Wilhelm comenta a atuação do espírito originário e do espírito consciente na formação do corpo humano: "Este espírito originário é desprovido de consciência e saber, mas é capaz de regular os processos formativos do corpo. O espírito consciente é manifesto e muito atuante, capaz de 
adaptar-se continuamente" (JUNG e WILHELM. 2012, p. 106). E prossegue o autor, "O espírito originário ama a tranquilidade, e o espírito consciente, o movimento. Em seus movimentos, permanece ligado aos sentimentos e desejos. Dia e noite consome a semente originária, até consumir completamente a força do espírito originário. O espírito consciente abandona a casca e sai." (idem, ibidem).

Apesar da dificuldade em lidarmos com essas noções nada familiares provenientes da cultura oriental, elas ajudam a iluminar a leitura de "Campo, chinês e sono", que, nos seus versos finais, parece tratar de uma 'força originária' a formar um corpo humano, cujo rosto expressa tranquilidade. Mesmo porque se o situarmos como o poema seguinte a "Vida menor", cuja enunciação é justamente a procura por uma experiência muda, anterior à linguagem e à constituição do sujeito, poderíamos interpretar que a ampliação gradativa que se faz das imagens do poema seria a representação dos passos necessários a um contato com a 'semente', da qual se originaria depois, por exemplo, a "rosa".

É como se o sujeito poético ainda não estivesse inicialmente preparado para distinguir a especificidade de um sujeito adormecido ("o chinês"), em sua relação com a natureza ("o campo"), e com as coisas, de modo que todos se confundissem num mesmo "sono perfeito". Mas a partir do movimento ativo da consciência em perguntar como apreender o ato de sonhar, ou seja, de buscar entender o que se esconderia atrás da sombra do sono, é como se o eu lírico passasse a portar uma lupa, de modo que as imagens das formigas, estrelas, peixes ganhassem outra dimensão, e o sujeito começasse a experimentar de perto a dimensão onírica ampliada, ouvindo inclusive a voz incompreensível das árvores, "E árvores dizem qualquer coisa / que não entendes", delas que costumam se reservar ao silêncio. ${ }^{31}$ Daí é efetuada a distinção entre "um chinês dormindo" e "um campo cheio de sono e antigas confidências". E para que se possa compreendê-las, é constituída a apóstrofe ao aguçamento do sentido da audição, que, aliado a uma visão também atenta, seriam capazes de proporcionar ao sujeito poético e ao leitor uma experiência literária do movimento

\footnotetext{
${ }^{31}$ Em "A árvore e o homem" de Passeios na ilha, lê-se sobre esse resguardo silencioso das árvores: "Desejaríamos que falassem, como falam os animais, como falamos nós mesmos. Entretanto, elas e as pedras reservam-se o privilégio do silêncio, num mundo em que todos os seres têm pressa de se desnudar" (DRUMMOND DE ANDRADE. 2011b, p. 21).
} 
imagético e sonoro de uma força originária da natureza, atemporal, dando forma a um corpo humano, metáfora talvez do mencionado "espírito consciente" que romperá a casca da semente e sairá ao mundo.

É interessante notar ainda que outro poema de A Rosa do Povo, "Fragilidade", parece teorizar a completa suspensão de um princípio relacional com o mundo exterior, figurando o momento mesmo da passagem de uma palavra a outra, como intervalo entre o som e o sentido, antes de se alcançar a chave imobilizadora do poema, ou seja, aludindo ao movimento da linguagem, que prescindisse da presença oratória do sujeito poético. ${ }^{32}$ No referido poema, podemos observar inclusive um diálogo com a noção de "arte pura" prescrita por Mallarmé: "A obra de arte, em sua pureza completa, implica o desaparecimento da presença oratória do poeta. Este deixa a iniciativa às palavras, ao choque de suas diferenças ativadas" (apud HAMBURGER, 2007, p. 112).

Mas ao retomarmos a suposição de que todo o movimento introspectivo de depuração da linguagem implicaria simultaneamente num processo de mundificação do sujeito lírico, na medida em que um novo corpo - que pode ser um poema, um livro, um sujeito - estaria sendo (re)feito na “noite", para emergir ao ambiente exterior, reafirma-se o caráter processual da obra de 45, que realiza uma conjunção tensa entre concepções poéticas contrastantes: de um lado, representando um quadro de total descompromisso com as questões presentes; e de outro, as exigências participativas, apropriando-se artisticamente, por exemplo, de conceitos da ideologia marxista. ${ }^{33}$

Exemplo dessa tensão é lido na crônica "O livro inútil", de Confissões de Minas, cuja reflexão põe em confronto o desejo da escritura de um livro alheio à experiência histórica, que permanecesse apenas na esfera da "arte pura", pintando o movimento da linguagem, a expressão do

\footnotetext{
${ }^{32}$ Os versos de "Fragilidade" retratam bem a intenção do eu lírico de permanecer suspenso em torno do movimento das palavras, sendo-lhe evidentemente exigidos, nesse trabalho, os sentidos da visão e da audição: "Não mais o desejo de explicar, e múltiplas palavras em feixe / subindo, e o espírito que escolhe, o olho que visita, a música / feita de depurações e depurações, a delicada modelagem / de um cristal de mil suspiros límpidos e frígidos: não mais / que um arabesco, apenas um arabesco / abraça as coisas, sem reduzi-las."

${ }^{33}$ Em "Poesia do tempo", de Confissões de Minas, há um discurso contrário a uma poesia de caráter hermético e evasionista: "A poesia não se 'dá', é hermética ou inumana, queixam-se por aí. Ora, eu creio que os poetas poderiam mostrar o contrário ao público. De que maneira? Abandonando a ideia de que poesia é evasão. E aceitando alegremente a ideia de que poesia é participação" (DRUMMOND. 2011, p. 182).
} 
deslocamento das palavras em "estado de dicionário", em face da contingência do devir humano, que necessita sempre refazer-se a cada instante, incorporando os ideais do tempo, sendo o próprio processo da escrita uma confirmação dessa exigência, ao materializar numa forma precária a experiência do momento que, no segundo seguinte, já não existe mais:

"Escrever um livro inútil, que não conduzisse a nenhum caminho e não encerrasse nenhuma experiência; livro sem direção como sem motivação; livro disfarçado entre mil, e tão vazio e tão cheio de coisas (as quais ninguém jamais classificaria, falto de critério), que pudesse ser considerado, ao mesmo tempo, escrito e não escrito, sempre foi um de meus secretos desejos. Os dias passaram sobre esse projeto e não o fizeram mais nítido; ambições mais diretas me agitaram; nunca soube quando chegaria o tempo desse livro, e nunca senti em mim a plenitude insuportável da maturação; será hoje? Se me disponho a escrevê-lo é porque já está feito... O mesmo seria dizer que minha vida está acabada. Quando me sinto capaz de nascer neste escasso momento e olhar com olhos ingênuos essa janela que se insere entre mim e a paisagem; ou aquela porta, que esconde um gato; ou o céu, onde passam aeroplanos postais. $\mathrm{O}$ homem acabado, o livro acabado são fórmulas; o homem que continua, o livro que continua e, sobretudo, o leitor que continua, estão insinuando como é difícil 'pintar a passagem', com o pincel que foge da minha mão, com a minha mão que se desprega do braço e navega por conta própria, sobre a crista da onda, da onda que, por sua vez..." (DRUMMOND DE ANDRADE. 2011a, p. 187-188)

No ensaio "Drummond e o livro inútil", João Adolfo Hansen desenvolve a partir da leitura desse texto a noção de uma "ética utópica da destruição", contida tanto na poesia quanto na prosa drummondianas, especialmente a partir de Sentimento do mundo (1940). Essa ética se basearia na recusa das normas da ordem estabelecida e na constante procura pelos seus pressupostos impensados, inerentes às palavras, aos valores, às coisas:

"O preceito implica não aceitar as coisas como se apresentam, mas regredir ao pressuposto delas para evidenciar sua particularidade e explicitar seus encadeamentos em teias microscópicas de causa-efeito que permaneçam impensadas para seus agentes, enredando-os em petrificações vividas como natureza. (...) deve transformá-las como 
história de vivos, buscando as formas possíveis de um futuro em que as palavras justiça e cultura não serão só palavras." (HANSEN. In: DRUMMOND DE ANDRADE. Confissões de Minas. 2011a, p. 252-253)

Como diz Hansen, o escritor tem de incessantemente escolher uma forma precária em meio às experiências do passado, à expectativa do futuro e às limitações do presente, sendo que os enunciados poéticos - "com o pincel que foge da minha mão, com a minha mão que se desprega do braço e navega por conta própria, sobre a crista da onda, da onda que, por sua vez..." - remetem para uma realidade utópica de uma experiência de totalidade só aludida, porque ainda não gozada por ninguém. E, retomando o pensamento adorniano, Hansen aduz que só com a transformação radical do estado dos modos de produção capitalista seria possível a reconciliação entre a materialidade histórica e o ideal pressuposto pelo escritor:

“(...) para ainda lembrar Adorno, ideal e material se afastam um do outro na tensão com que o escritor figura o infigurável em uma arte cuja utopia faria enfim coincidir a dissimetria de reflexão e sensibilidade, possível e real, abolindo a experiência frustrada das violências do passado, o tempo horrível do presente do autor e do leitor divididos pela classe e pela morte, e a si mesma, ficção, como coisas finalmente acabadas e verdadeiramente inúteis, na forma de um livro afinal e justamente inútil.” (idem, p. 259)

Para Hansen, o "livro inútil”" corresponderia à 'realização da utopia da arte moderna', um livro desprovido de qualquer determinação precedente à escritura, a abolição final das contradições do sujeito e da sociedade, ou seja, a referência a uma obra e a um homem acabados, o mesmo que se lê, por exemplo, no poema "Desligamento do poeta", de Impurezas do branco (1973), referente a Manuel Bandeira já morto. ${ }^{34}$ Mas, segundo o crítico, não há nada na poesia e na prosa drummondianas que contenha o idealismo romântico de um "eu ilimitado", cuja consciência infeliz seria superiormente crítica em relação a um mundo incapaz de proporcionar a experiência do

\footnotetext{
34 "A arte completa, / a vida completa, / o poeta recolhe seus dons, / o arsenal de sons e signos, / o sentimento de seu pensamento (...)" ("Desligamento do poeta").
} 
"absoluto"; esse mesmo "eu fundamental" que, por recusar a realidade humana, busca numa ideia de 'sublime' o remédio para sua inadequação face ao ambiente exterior. Assim, diante da impossibilidade de alcançar essa plenitude por meio de uma solução de natureza transcendental, resta a Drummond a atividade de escrever, atento aos desejos recalcados na história, e às intuições de revolta fornecidas por um ideal de futuro contra as limitações de sua época.

A partir da reflexão acima, podemos questionar em até que ponto o desejo de evasão explicitado em "Vida menor", assim como em outros poemas de A Rosa do Povo com característica semelhante, configuraria uma espécie de atitude 'romântico-simbolista' de isolamento ou alienação no tocante à sociedade, já que, nas palavras de Michael Hamburger, "Em certo sentido, todos os poetas com atitudes romântico-simbolistas foram não-políticos, na medida em que seus valores se originaram da imaginação, e a imaginação é por demais radical e utópica para se adaptar a problemas politicos propriamente ditos" (HAMBURGER. 2007, p. 120), relativizando, assim, o comprometimento político de Drummond?

Poderia essa espécie de retiro a uma privacidade apolítica, na medida em que redimisse o poema de uma influência exterior supostamente indesejável, frustrar o sujeito em suas intenções originais de engajamento? No entanto, é preciso ressaltar que, desde Sentimento do mundo (1940), o poeta já vinha recusando uma postura não-política ou antipolítica no "formidável período histórico que lhe é dado viver" (DRUMMOND DE ANDRADE. 2011a, p. 13). Pois isso implicaria em ser conservador ou reacionário, diante dos regimes que perpetuavam ordens estabelecidas de poder e privilégio. $^{35}$

Assim, o poeta parece explorar no livro de 45 a tensão entre uma atitude solipsista e o envolvimento ativo com as questões sociais, buscando explorar a tensão entre uma poesia misteriosa e descompromissada, cuja linguagem adquiriria características mais complexas e matizadas; e uma poesia engajada, cuja linguagem se mostraria mais despojada, incisiva e direta

\footnotetext{
${ }^{35}$ Exemplo dessa recusa pode ser lida na crônica "Poesia do tempo" de Confissões de Minas: "Participação na vida, identificação com os ideais do tempo, (e esses ideais existem sempre, mesmo sob as mais sórdidas aparências de decomposição), curiosidade e interesse pelos outros homens, apetite sempre renovado em face das coisas, desconfiança da própria e excessiva riqueza interior, eis aí algumas indicações que permitirão ao poeta deixar de ser um bicho esquisito para voltar a ser, simplesmente, um homem." (DRUMMOND DE ANDRADE. 2011a, p. 182)
} 
para a comunicação, conciliando as exigências supostamente antagônicas da estética e da experiência, como se a sua arte estivesse situada nessa combinação de contrários. Nesse sentido, é interessante trazer a reflexão final de Drummond contida na crônica "Em busca da linguagem própria", publicada em $O$ Jornal, do Rio de Janeiro, em 16 de julho de 1944, na qual o poeta sublinha que a empatia de seu texto com o público leitor só se consumará por meio de uma linguagem autêntica e depurada, mesmo que ela englobe as características mais diversas:

"Só a própria linguagem do poeta, apurada por um trabalho constante e muitas vezes cruel, mas que não interessa ao público, como não lhe interessa o modo de fabricação dos relógios ou a composição química dos adubos utilizados num jardim, só essa linguagem pessoal, corajosa, dinâmica, misteriosa se for o caso, feérica, mágica, enfim, logrará cativar esse leitor indiscriminado a que podemos chamar de "qualquer do povo"”. (DRUMMOND DE ANDRADE. 2002b, p. 43)

Apreende-se, portanto, que os poemas "Vida menor" e "Campo, chinês e sono" projetam o eu lírico num espaço longínquo e utópico, alheio ao convívio humano e integrado à natureza, mas também configuram uma etapa do processo de composição da obra na sua totalidade, indicando a operação de depuração de uma linguagem poética própria e, por consequência, de apuração do poema, do sujeito poético, do poeta e do leitor. ${ }^{36}$ Daí o caráter poético e processual do livro, que é uno e múltiplo, permitindo a leitura individual dos poemas, bem como uma visão gradativa do todo.

Por meio desse trabalho de condensação, é possível acessar uma espécie de "força essencial" simbólica, da qual emergirá "o caule / traço indeciso (...) o cálice” de "Anunciação da rosa”, que, na articulação da obra como um todo, se abrirá em flor. Assim, reafirma-se a autodefinição drummondiana como "poeta do finito e da matéria", na medida em que, para tratar tanto de questões de natureza histórico-materiais como transcendentes, o poeta busca um domínio sobre o

\footnotetext{
${ }^{36}$ Mesmo porque, o próprio Drummond afirma, em "A árvore e o homem" de Passeios na ilha, o caráter político dos seres humanos, que "tampouco sabem integrar-se no conjunto natural onde folhas, raízes, insetos e ventos se organizam sem política" (DRUMMOND DE ANDRADE. 2011b, p. 24), só podendo aludir a uma espécie de "primitiva unidade de que houvéssemos perdido a memória" (idem, ibidem).
} 
que o poema, enquanto carne de palavras, simboliza, criando inclusive imagens poéticas miniaturizantes, que lhe proporcionam uma sensação maior, embora precária, de resguardo da individualidade, sendo esse talvez um passo necessário à conversão da voz mais íntima em canto socializante.

\subsection{Desejo, corpo, utopia: "O mito"}

O poema "O Mito" narra a trajetória do sujeito poético que, por meio de uma espécie de "ritual de passagem", compreende que Fulana representa simbolicamente o seu desejo, explorando no texto tanto aspectos psicológicos quanto mitológicos, ao mesmo tempo que parece configurar uma alegoria da dominação exercida pela classe burguesa possuidora dos meios de produção sobre as demais classes sociais. O poema se inicia com a enunciação do amor tenso do eu lírico por uma mulher idealizada, que nem sequer o conheceria, retratando assim uma cisão entre o sujeito e o objeto do desejo:

\section{“O MITO}

Sequer conheço Fulana, vejo Fulana tão curto, Fulana jamais me vê, mas como eu amo Fulana.

$5 \quad$ Amarei mesmo Fulana? ou é ilusão de sexo? Talvez a linha do busto, da perna, talvez do ombro.

Amo Fulana tão forte, 10 amo Fulana tão dor, 
que todo me despedaço

e choro, menino, choro.

Mas Fulana vai se rindo...

Vejam Fulana dançando.

15 No esporte ela está sozinha.

No bar, quão acompanhada.

E Fulana diz mistérios,

diz marxismo, rimmel, gás.

Fulana me bombardeia,

20

no entanto sequer me vê.

E sequer nos compreendemos.

É dama de alta fidúcia,

tem latifúndios, iates,

sustenta cinco mil pobres.

25 Menos eu... que de orgulhoso

me basto pensando nela.

Pensando com unha, plasma,

fúria, gilete, desânimo.

Amor tão disparatado.

30 Desbaratado é que é...

Nunca a sentei no meu colo

nem vi pela fechadura.

Mas eu sei quanto me custa

manter esse gelo digno,

35

essa indiferença gaia

e não gritar: Vem, Fulana!

Como deixar de invadir

sua casa de mil fechos

e sua veste arrancando

40

mostrá-la depois ao povo 
tal como é ou deve ser:

branca, intata, neutra, rara,

feita de pedra translúcida,

de ausência e ruivos ornatos.

45

Mas como será Fulana,

digamos, no seu banheiro?

Só de pensar em seu corpo

o meu se punge... Pois sim.

Porque preciso do corpo

50 para mendigar Fulana,

rogar-lhe que pise em mim,

que me maltrate... Assim não.

Mas Fulana será gente?

Estará somente em ópera?

55 Será figura de livro?

Será bicho? Saberei?

Não saberei? Só pegando,

pedindo: Dona, desculpe...

O seu vestido esconde algo?

60 tem coxas reais? cintura?

Fulana às vezes existe

demais; até me apavora.

Vou sozinho pela rua,

eis que Fulana me roça.

65 Olho: não tem mais Fulana.

Povo se rindo de mim.

(Na curva do seu sapato

o calcanhar rosa e puro.)

E eu insonte, pervagando

70

em ruas de peixe e lágrima.

Aos operários: a vistes? 
Não, dizem os operários.

Aos boiadeiros: A vistes?

Dizem não os boiadeiros.

Acaso a vistes, doutores?

Mas eles respondem: Não.

Pois é possível? pergunto

aos jornais: todos calados.

Não sabemos se Fulana

80

passou. De nada sabemos.

E são onze horas da noite,

são onze rodas de chope,

onze vezes dei a volta

de minha sede; e Fulana

85

talvez dance no cassino

ou, e será mais provável,

talvez beije no Leblon,

talvez se banhe na Cólquida;

talvez se pinte no espelho

90

do táxi; talvez aplauda

certa peça miserável

num teatro barroco e louco;

talvez cruze a perna e beba,

talvez corte figurinhas,

95 talvez fume de piteira,

talvez ria, talvez minta.

Esse insuportável riso

de Fulana de mil dentes

(anúncio de dentifrício)

100 é faca me escavacando.

Me ponho a correr na praia. 
Venha o mar! Venham cações!

Que o farol me denuncie!

Que a fortaleza me ataque!

105 Quero morrer sufocado,

quero das mortes a hedionda,

quero voltar repelido

pela salsugem do largo,

já sem cabeça e sem perna,

110 à porta do apartamento,

para feder: de propósito,

somente para Fulana.

E Fulana apelará

para os frascos de perfume.

115 Abre-os todos: mas de todos

eu salto, e ofendo, e sujo.

E Fulana correrá

(nem se cobriu: vai chispando)

talvez se atire lá do alto.

120 Seu grito é: socorro! e deus.

Mas não quero nada disso.

Para que chatear Fulana?

Pancada na sua nuca

na minha é que vai doer.

125 E daí não sou criança,

Fulana estuda meu rosto.

Coitado: de raça branca.

Tadinho: tinha gravata.

Já morto, me quererá?

130 Esconjuro, se é necrófila...

Fulana é vida, ama as flores,

as artérias e as debêntures. 
Sei que jamais me perdoará

matar-me para servi-la.

135 Fulana quer homens fortes,

couraçados, invasores.

Fulana é toda dinâmica,

tem um motor na barriga.

Suas unhas são elétricas,

140 seus beijos refrigerados,

desinfetados, gravados

em máquina multilite.

Fulana, como é sadia!

Os enfermos somos nós.

145 Sou eu, o poeta precário

que fez de Fulana um mito, nutrindo-me de Petrarca,

Ronsard, Camões e Capim;

que a sei embebida em leite,

150 carne, tomate, ginástica,

e lhe colo metafísicas,

enigmas, causas primeiras.

Mas, se tentasse construir

outra Fulana que não

155 essa de burguês sorriso

e de tão burro esplendor?

Mudo-lhe o nome; recorto-lhe

um traje de transparência;

já perde a carência humana;

160 e bato-a; de tirar sangue.

E lhe dou todas as faces

de meu sonho que especula; 
e abolimos a cidade

já sem peso e nitidez.

165 E vadeamos a ciência,

mar de hipóteses. A lua

fica sendo nosso esquema

de um território mais justo.

E colocamos os dados

170 de um mundo sem classe e imposto;

e nesse mundo instalamos

os nossos irmãos vingados.

E nessa fase gloriosa,

de contradições extintas,

175 eu e Fulana, abrasados,

queremos... que mais queremos?

E digo a Fulana: Amiga,

afinal nos compreendemos.

Já não sofro, já não brilhas,

180 mas somos a mesma coisa.

(Uma coisa tão diversa

da que pensava que fôssemos.)"

A exposição de um inventário de dores, aliado à narração imaginária de um voyeurismo mórbido e minucioso dos possíveis interesses, pensamentos, hábitos cotidianos, contornos do corpo de Fulana, indicam que o sujeito lírico oscila o tempo todo entre o desejo de renegá-la e de possuíla, sendo ela, além de qualquer mulher ou sujeito histórico específico, o nome que assume o desejo dentro desse sujeito agônico, numa espécie de luta entre a passividade melancólica e a urgência de 
vitalidade e satisfação de suas pulsões. ${ }^{37}$ Um dos eixos do poema discorre sobre essa tensão entre vida e morte, insuperável no plano da realidade material, na medida em que o eu lírico toma consciência de que o impulso sexual faz parte dele mesmo, como se pode ler nas três estrofes de abertura.

A tensão gerada pela insatisfação do desejo transpõe-se também para o eixo das relações sociais trabalhado no poema. A existência de um mundo capitalista baseado numa sociedade de classes seria uma das causas da existência de mulheres idealizadas e inatingíveis, de desejos sexuais reprimidos, de incompreensão entre seres humanos, de injustiça. $\mathrm{O}$ eu lírico constata que Fulana, enquanto metáfora do desejo, acaba por metaforizar, também, a distância social que separa o sujeito desta figura construída a partir de imagens da alta burguesia: "É dama de alta fidúcia, / tem latifúndios, iates, / sustenta cinco mil pobres". Ao estabelecer uma distância artificial entre os indivíduos, a clivagem social geraria no eu lírico uma visão contraditória acerca da figura de Fulana: simultaneamente um ser idealizado, metafísico, "tal como é ou deve ser: / branca, intacta, neutra, rara"; mas, também, banal, desidealizada, comum, "que a sei embebida em leite, / carne, tomate, ginástica”.

Podemos dizer que o tratamento do tema do desejo, em "O mito", seja talvez influenciado pela poética de As flores do mal, marco da poesia moderna em que, segundo Erich Auerbach, é tratado com frequência esse tema, criando-se uma atmosfera "ao mesmo tempo sensual, fria, bestial, dolorosa, demoníaca e sublime” (AUERBACH. 2007, p. 317). Vale lembrar que o próprio Drummond já admitiu na crônica "Vinte livros na ilha" de Confissões de Minas, que Les Fleurs du mal está entre os livros por ele considerados como "companheiros da hora íntima, depositários da nossa confidência" (DRUMMOND DE ANDRADE. 2011a, p. 207).

Entende Auerbach que, apesar de se utilizar de procedimentos da escrita que remetem ao estilo elevado (ritmo, forma), Baudelaire transfigurou os temas tradicionais da poesia amorosa sublime, como os da celebração da amada e da intimidade idílica dos românticos, passando a

\footnotetext{
${ }^{37}$ A palavra 'fulana' também carrega um sentido pejorativo, de anonimato, impessoalidade. Etimologicamente, 'fulano' provém da palavra árabe "fulán", remetendo ainda, talvez, a uma ideia de estrangeiro, de 'infiel', que no imaginário ocidental sempre foi associado à figura do 'diabo'.
} 
enfatizar os aspectos terríveis e misteriosos de uma sexualidade explícita, de caráter rebaixado, produzindo assim os primeiros poemas a misturar o amor físico, antes restrito ao "estilo ligeiro"; o perverso ou abjeto, que não se enquadrava em qualquer categoria estilística; e os anseios sobrenaturais, relativos ao estilo sublime:

"Em quase todo Baudelaire a relação entre amantes - ou mais precisamente entre os que estão ligados pela atração sexual - é representada como uma obsessão misturada ao ódio e ao desprezo, um vício que não perde nada de sua força atormentada e degradante ao ser experimentado em plena (e indefesa) consciência. O amor é um tormento, no melhor dos casos um entorpecimento dos sentidos; claro, é também a fonte de inspiração, a verdadeira fonte da intuição mística do sobrenatural; no entanto, é tortura e degradação." (AUERBACH. 2007, p. 317)

Assim como em Baudelaire, o desejo é tido como sofrimento no poema "O mito", gerando ao sujeito lírico experiências vexatórias e angustiantes, além de sentimentos de agressividade:

"Quero morrer sufocado,

quero das mortes a hedionda,

quero voltar repelido

pela salsugem do largo,

já sem cabeça e sem perna,

à porta do apartamento,

para feder: de propósito,

somente para Fulana.

E Fulana apelará

para os frascos de perfume.

Abre-os todos: mas de todos

eu salto, e ofendo e sujo." 
Note-se que o verbo "feder" indica uma atitude de agressão, por parte de um sujeito que se vê frustrado na satisfação da sua necessidade face ao objeto inalcançável, o que reafirma a relação tortuosa decorrente dessa cisão.

Para Baudelaire, segundo Auerbach, o amor, apesar de degradante, seria ainda uma via de acesso à experiência mística, mesmo porque o poeta francês "foi influenciado pelas imagens $e$ idéias cristãs medievais. Também é verdade que Baudelaire tinha a mente de um místico; no mundo dos sentidos ele buscava o sobrenatural" (AUERBACH. 2007, p. 322). ${ }^{38}$ De acordo com o crítico alemão, embora As Flores do mal não possa ser lida a despeito da tradição cristã, seria importante sublinhar a sua incompatibilidade com esta, na medida em que o poeta não teria nunca procurado qualquer espécie de esperança de redenção pela graça divina, mas sim o nada, "ou uma espécie de satisfação sensorial, a visão de uma artificialidade estéril porém sensual" (idem, p. 323).

Não podendo avaliar a justeza dessa opinião, na medida em que nos exigiria uma nova pesquisa específica, podemos sublinhar a partir dela uma diferença essencial entre as poéticas de $A s$ Flores do mal e de A Rosa do Povo. Como já vimos falando ao longo deste estudo, a poética da obra de 45 é atravessada por uma dicção esperançosa, criadora de imagens salvíficas. Ao contrário do poeta francês, que "odiava o tempo em que viveu" (idem, p. 325), Drummond reconhece o valor histórico da década de 1940, compreendendo que, com a Segunda Guerra, o mundo estaria passando por uma "transformação pelo fogo" (DRUMMOND DE ANDRADE. 2011a, p. 12) da qual surgiria uma nova “Ordem” (“Carta a Stalingrado”).

Em decorrência desse discurso esperançoso, o sujeito lírico de "O mito" também acaba por apresentar uma espécie de saída utópica ao final do poema, de modo a apaziguar os tormentos provenientes do seu desejo frustrado. Por mais ambígua que seja essa resolução - e o próprio título do poema já remete a esse lugar de incertezas -, o eu lírico pinta um quadro em que ele despiria

\footnotetext{
${ }^{38}$ Com relação à influência do imaginário cristão na obra baudelairiana, é interessante ler a apresentação de Manuel Bandeira à coletânea de traduções de Guilherme de Almeida, intitulada Flores das Flores do mal de Baudelaire: "No entanto, a uma análise mais atenta, a sua obra se revela profundamente cristã. Somente, o que distingue o seu cristianismo de Lamartine e outros românticos, é que este era, como advertiu Thibaudet, um cristianismo sem consciência do pecado original, ao passo que o de Baudelaire está intimamente penetrado desta noção. Como viria a dizer nosso Murilo Mendes, o poeta das Flores do mal se sentia de Deus tanto na boa ação quanto no pecado, e talvez mais no pecado" (BAUDELAIRE. 2010, p. 11).
} 
Fulana de suas vestes e máscaras sociais, a individualizaria com um nome próprio e, depois, passaria a agredi-la severamente ("e bato-a; de tirar sangue"), o que metaforiza uma autoimolação do desejo, encerrada numa manifestação de ódio no que toca à insaciabilidade das necessidades da carne, referindo-se, talvez, ao poema "Aquela que é demasiado alegre", de As Flores do mal (BAUDELAIRE. 2003, p. 313 e 315):

"Essas saias extravagantes

Exteriorizam teu espírito colorido;

És uma original que me põe louco,

Odeio-te tanto como te amo

(...)

Gostaria assim numa noite,

Ao soarem as badaladas da volúpia,

Rastejar, silente e à traição,

Até junto dos tesouros da tua pessoa

Para castigar o júbilo desse corpo,

Magoar teu seio perdoado

E abrir ao longo do teu flanco atónito

Uma ferida longa larga e funda

E, numa vertiginosa doçura,

Nesses lábios assim criados

(Tão belos quanto fascinantes)

Inocular-te meu veneno fraterno.”

A imagem de rasgar o corpo é ainda mais violenta que a de bater até tirar o sangue; mas ambas podem remeter a uma ideia de conjuração dos tormentos da volúpia por meio da flagelação da carne, própria ou alheia. Assim, é possível pensar se essas imagens não explorariam ainda uma noção de perversão sado-masoquista relacionada à satisfação do desejo, remetendo ainda, no caso de Drummond, a estes versos de "Vulgívaga", da coletânea Carnaval (1919) de Manuel Bandeira: 
"Se bate, então como estremeço!

Oh, a volúpia da pancada!

Dar-me entre lágrimas, quebrada

Do seu colérico arremesso...

(...)

Não posso crer que se conceba

Do amor senão o gozo físico!

O meu amante morreu bêbado,

E meu marido morreu tísico!"

No poema "O mito", nota-se também a intenção poética de se atribuir um corpo a Fulana, a qual se caracteriza como uma espécie de fantasma a atormentar o sujeito; mas é certo também que essa corporificação só se dá na esfera da fantasia, que é o poema, já que o desejo, dada sua natureza, permanece sempre insaciável no corpo.

No já comentado texto de Agamben, "Infância e História: Ensaio sobre a destruição da experiência", há um tópico intitulado "Cavalcanti e Sade (O desejo e a necessidade)". Nele é discutida a questão da expropriação da fantasia no âmbito da experiência, o que lança uma sombra sobre esta última, e a sombra é o desejo, já que a experiência passou a ser inapropriável e inexaurível. Já na cultura medieval, fantasia e desejo eram conexos, e aquela atuava como elemento de mediação entre o sujeito e o objeto desejado, caracterizando-se como o veículo para a satisfação do desejo:

"O fantasma, que é a verdadeira origem do desejo (...) é também - como mediador entre o homem e o objeto - a condição de apropriabilidade do objeto do desejo, e logo, em última análise, de sua satisfação. A descoberta medieval do amor por obra dos poetas provençais e estilnovistas é, deste ponto de vista, a descoberta de que o amor tem como objeto não diretamente a coisa sensível, mas o fantasma; é, portanto, simplesmente a descoberta do caráter fantasmático do amor. Mas, dada a natureza medial da fantasia, isto significa que o fantasma é, também, o sujeito e não simplesmente o objeto do eros." (AGAMBEN. 2008, p. 35) 
Na medida em que para os poetas provençais e estilnovistas o amor tem o seu único lugar na fantasia, o desejo não é nunca corpóreo, tendo, no fantasma, o sujeito-objdeeto do amor, no qual é experimentada a fusão entre o sujeito desejante e o objeto do desejo. ${ }^{39}$ Como essa fusão só se dá no fantasma, os poetas provençais acabam por definir o amor "como um 'amor consumado' (fin'amors), cujo gozo não tem fim (...) e, coligando-o com a teoria averroísta que vê no fantasma o lugar em que se cumpre a união do indivíduo com o intelecto agente, transformar o amor em uma experiência soteriológica" (idem, ibidem).

Segundo Agamben, sobrevive nos romances de Sade, de maneira transfigurada, o projeto edênico da poesia trovadoresco-estilnovista, conferindo à perversão o mesmo papel que o fantasma ou a mulher-anjo desempenhava na poesia trovadoresca: “Daí, no universo sadiano, a necessidade de perversão, que, fazendo coincidir desejo e necessidade, transforma em gozo a frustração essencial do desejo. Pois o que o perverso reconhece é que é o próprio desejo (na medida em que não lhe pertence) a apresentar-se, no outro, como necessidade" (idem, p. 36).

A partir das reflexões acima, não seria possível apreender que um dos eixos do poema “O mito" consiste na questão da cisão entre desejo e necessidade, configurando ele mesmo um meio fantasioso de fazer novamente combinar as duas metades cindidas de Eros? Vale lembrar que na sua Antologia poética de 1962, Drummond dispôs esse poema na seção “Amar-Amaro”, que trata do "conhecimento amoroso", como ele próprio reconhece na nota da primeira edição. Além disso, é evidente que há em "O mito" referência à poesia trovadoresca-estilnovista, já que o eu lírico se refere a Francesco Petrarca, poeta provençal amoroso e melancólico:

\author{
"Sou eu, o poeta precário \\ que fez de fulana um mito \\ nutrindo-me de Petrarca \\ Ronsard, Camões e Capim;”
}

\footnotetext{
${ }^{39}$ Segue a definição de Agamben para estilnovista: "Poeta do stilnovo, estilo adotado por certos autores italianos dos séculos XIII e XIV, Dante entre eles. Renovaram a tradição lírica cortês com grande apuro formal, exaltando o amor e a imagem da mulher como meio de elevação espiritual" (AGAMBEN. 2008, p. 35).
} 
Petrarca, segundo Otto Maria Carpeaux, é o primeiro poeta lírico moderno, por mesclar a índole medieval a sentimentos modernos, apesar de ter nascido no século XIV e escrever "nas formas provençais e do 'dolce stil novo"” (CARPEAUX. 2011, p. 263). Ronsard, por sua vez, é outro poeta amoroso que, formado nos modelos gregos antigos, costumava pintar "noites melancólicas, sensualidades agressivas e elevações espirituais” (idem, p. 417). Já Camões se caracteriza pelo rompimento com uma poesia amorosa de caráter mais platônico dos estilnovistas Dante e Petrarca, passando a trazer o amor mais para o corpo, valorizando a relação erótica com uma mulher corpórea.

José Guilherme Merquior entende que haveria em "O mito" uma espécie de “antipetrarquismo radical", como se no "realismo social" de A Rosa do Povo houvesse uma recusa da "ética da paixão", de modo que Eros tivesse perdido "seu fascínio e prestígio" (MERQUIOR. 1975, p. 89). Segundo Merquior, a referência de Drummond a "capim" (alimento do "burro"), ao lado dos demais poetas (supostamente petrarquistas), indicaria essa recusa, de modo que qualquer tentativa de transfiguração poética de algum ser ou objeto real representasse uma postura de servidão ideológica:

"Mulher atlética e positiva. Fulana destrói o mito do amor petrarquista. Empanturrarse de Petrarca e seus discípulos, de que o mais ilustre em português é Camões, não passa de estupidez (...) ('capim', o alimento do 'burro'), se se trata apenas de transfigurar estupidamente mulheres - porque a transfiguração em si mesma não passa de servidão ideológica. Debaixo da mulher fatal - a boneca burguesa - se entrevê então uma outra eva (...). O 'esplendor burro' de Fulana é apenas um ídolo burguês. Num outro mundo social, a deusa se humanizaria completamente. (...) Em A Rosa do Povo, pois, o lirismo crítico de Drummond tende a recusar a ética da paixão. Este antipetrarquismo radical está nas antípodas do 'amour fou' pregado por Breton. Esta não é, em absoluto, a última palavra de Drummond sobre o sexo e o amor. Mais tarde, para além de toda cegueira ideológica, Eros saberá reconquistar seu fascínio e prestígio. Com a leitura de 'O mito', pretendemos apenas assinalar a força do realismo social drummondiano". (MERQUIOR. 1975, p. 88-89) 
Em relação aos versos "Sou eu, o poeta precário / que fez de fulana um mito / nutrindo-me de Petrarca, / Ronsard, Camões e Capim”, José Guilherme Merquior não parece perceber o seu tom autoirônico e, o que é mais relevante, deixa de lado o estatuto eminentemente literário do poema em análise, o qual suplanta qualquer intenção "realista social" que se lhe queira atribuir. Diferentemente da leitura de Merquior, não me parece existir "antipetrarquismo" em "O mito", mas, antes, a afirmação da consciência do poeta acerca da sua precariedade, enquanto indivíduo que tentasse encontrar solução para as pulsões do desejo por meio da poesia, repetindo fórmulas idealizantes do passado. Pois existe, no poema, o reconhecimento de que o desejo, por estar fatalmente vinculado ao corpo, permanece sempre insaciável no âmbito do poético, retratando, assim, a consciência acerca dos limites do literário para solucioná-lo:

\footnotetext{
"que a sei embebida em leite, carne, tomate, ginástica, e lhe colo metafísicas, enigmas, causas primeiras.
}

Mas, se tentasse construir outra Fulana que não essa de burguês sorriso e de tão burro esplendor?"

O fantasma do desejo, Fulana, é que se encontra solapado pelo "esplendor burro" burguês. E o papel do poeta seria expor essa aderência ideológica na esfera do poético, retirando-lhe as vestes opacas, "recorto-lhe / um traje de transparência", e propondo, ao final, uma solução absolutamente literária, e de caráter utópico, porque idealizada num 'não lugar'. O sujeito vale-se de suas referências literárias do passado: a do projeto edênico amoroso da poesia trovadoresca, em que a figura do fantasma reúne o sujeito desejante e o objeto do desejo; bem como a perversão de Sade, na qual coincidem desejo e necessidade, sendo transformada em gozo a frustração essencial do 
desejo. Além disso, incorpora referências ideológicas e poéticas contemporâneas, como o marxismo, que faz a crítica à sociedade do consumo e à divisão do mundo em classes.

Não podemos concordar, assim, que haveria uma recusa do tema de Eros na poética de $A$ Rosa do Povo, como o diz José Guilherme Merquior, de modo a prevalecer "a força do realismo social drummondiano" (MERQUIOR. 1975, p. 89), supostamente a marca dessa fase de sua escrita. Como já dissemos, a obra de 45 se caracteriza pela intenção de abarcar o maior número de temas que já vinham sendo trabalhados na poesia de Drummond, além de apontar para temas de poéticas futuras, estando todos os poemas deste livro marcados por evidentes tensão emocional e originalidade expressiva, sendo justamente por isso, talvez, um dos pontos mais altos de toda sua obra. $^{40}$

Vale ressaltar que a temática do desejo tem presença constante na obra poética drummondiana que antecede A Rosa do Povo. Se em Alguma poesia (1930) há diversos poemas a abordar esse tema, no segundo livro de Drummond, Brejo das almas (1934), a temática da frustração sexual se intensifica ainda mais, tornando-se um dos eixos centrais da coletânea. São inúmeros os poemas a tratar desse assunto, partindo sempre de um sujeito poético sufocado por desejos que não se realizam. No ensaio "Uma poética da indecisão: Brejo das almas" (2000), Vagner Camilo sublinha a correlação conflituosa entre a problemática amorosa e ideológica, como se a isenção política do eu prendesse-o em seu próprio individualismo, afundado no terreno obscuro e movediço dos desejos reprimidos:

"Ora, a neutralidade política do cenário em que o eu projeta suas figuras femininas não é gratuita. Sendo uma projeção das carências do eu lírico, é esse um modo de ressaltar a própria condição do poeta, que, na impossibilidade de se definir ideologicamente, permanece centrado em seu individualismo e na sua problemática amorosa. Drummond acaba assim por atestar de forma cabal a articulação entre obsessão sexual e neutralidade política." (CAMILO. 2000, p. 51)

\footnotetext{
${ }^{40}$ A exemplo o verso: "Como fugir ao mínimo objeto / ou recusar-se ao grande?” (“Consideração do poema”).
} 
De acordo com Camilo, a falta de um posicionamento ideológico impediria que o poeta encontrasse uma solução artística que desse forma e sublimasse o conflito apontado, sendo comum na coletânea de 34 poemas autodepreciativos, como "O vôo sobre as igrejas", em que o eu lírico se põe em posição de inferioridade e distância em relação ao "poder de comunhão plena encarnado pela obra de Aleijadinho" (idem, p. 55). A solução do autocentramento individualista se mostraria sempre conflituosa e falha diante dos apelos da realidade exterior, de modo que o impulso de fuga contido no "voumemborismo" ficasse sempre a meio do caminho, como está materializado, por exemplo, na atitude dubitativa do eu do poema "Segredo". ${ }^{41}$

A respeito da indecisão política do poeta no contexto da década de 1930, John Gledson transcreve trecho da entrevista de 26/05/1931 concedida ao jornal A Pátria, na qual Drummond faz um ataque aos escritores da sua geração, acusando-os de nada terem construído de permanente, de modo que só lhes restariam soluções extraliterárias, como a religião, a política e a psicanálise:

"Espiritualmente, a minha geração está diante de três rumos, ou de três soluções Deus, Freud e o comunismo. A bem dizer, os rumos são dois apenas: uma ação católica, fascista e organizada em "Defesa do Ocidente" de um lado; do outro lado o paraíso moscovita, com a sua terrível e por isso mesmo envolvente sedução. Que é um apelo a tudo quanto subsiste em nós de romântico e descontrolado. Mas entre as duas posições, que impõem duas disciplinas, há lugar para a simples investigação científica, que nos fornece a chave, e por assim dizer o perdão dos nossos erros mais íntimos e das nossas mais dolorosas perplexidades. "Vamos todos para a Pasárgada" é o grito que o crítico Mário de Andrade ouviu de quase todas as nossas bocas, e creio que ouviu bem... Aqueles a quem o tomismo não consola e o plano qüinqüenal não interessa, esses se voltam para a libertação do instinto, o supra-realismo e a explicação dos sonhos, no roteiro da psicanálise. Ao ceticismo, à disponibilidade, à não opção sucede - nova moléstia do espírito - essa "ida a Pasárgada", paraíso freudiano, onde o poeta Manuel Bandeira afirma que tem "a mulher que eu quero, na cama que escolherei", além de muitas outras utilidades que correspondem à satisfação de

\footnotetext{
41 "A poesia é incomunicável. / Fique torto no seu canto. / Não ame. // Ouço dizer que há tiroteio / ao alcance do nosso corpo. / É a revolução? o amor? / Não diga nada. // Tudo é possível, só eu impossível. / O mar transborda de peixes. / Há homens que andam no mar / como se andassem na rua. / Não conte. // Suponha que um anjo de fogo / varresse a face da terra / e os homens sacrificados / pedissem perdão. / Não peça" ("Segredo").
} 
muitos outros impulsos seqüestrados. (...) Quanto à minha atitude pessoal diante desses três rumos possíveis, creio que não interessa aos leitores de A Pátria." (DRUMMOND DE ANDRADE. In: GLEDSON. 1981, pp. 90-91)

Segundo Gledson, essa entrevista revela uma não pactuação de Drummond com qualquer dos três rumos apontados. Todavia, o texto indica uma atitude tensa do poeta entre uma subentendida inclinação pelo "voumemborismo", no e pelo qual buscaria uma espécie de "libertação dos instintos", ao mesmo tempo em que a opção do comunismo já se mostrava como um paraíso sedutor... Já a opção da religião católica se relacionava com o fascismo, sendo já um rumo provavelmente descartado, o que vem a se confirmar na década de 40, como se lê na nota "Religião e poesia" de Confissões de Minas, em que se fala da ineficácia do catolicismo no enriquecimento da poesia de Murilo Mendes. ${ }^{42}$

No poema "O mito", Fulana se constitui enquanto metáfora do desejo sexual reprimido do sujeito. Sua figura remete a todas as mulheres, às vezes se reduz a um pedaço do corpo e, simultaneamente, é nenhuma, pois intangível. É retomada aqui não só a figura da "mulher fatal", como também a das mulheres situadas em terras distantes, como a referência à Cólquida, terra de Medeia ("talvez se banhe na Cólquida"), alusão mitológica que atribui um caráter ainda mais ambíguo a Fulana. ${ }^{43}$

A repressão sexual gerada por uma realidade histórica cria um jogo sempre tenso entre o sujeito lírico e Fulana, fazendo da experiência do desejo um mito, e do seu objeto uma "Fulana" todas, nenhuma, qualquer uma, tudo e nada ao mesmo tempo. Trata-se de um jogo de forças sem saída, inconcluso, na medida em que o mito não se resolve. A experiência do desejo por Fulana faz com que o eu lírico insira a realidade histórica na esfera do mito. Por meio de um trabalho de

\footnotetext{
42 "Em suma, a religião não trouxe nenhuma felicidade a Murilo Mendes - e nem o poeta, que é dos mais dignos, seria capaz de conceber esse cálculo; mas verifica-se que não lhe trouxe também nenhum enriquecimento ou plenitude poética, não o armou de poderes líricos para dominar a desordem do mundo" (DRUMMOND DE ANDRADE. 2011a, p. 186).

${ }^{43}$ Segundo Vagner Camilo, citando Mario Praz, a menção a mulheres sedutoras localizadas em terras exóticas se caracterizaria como " "projeção fantástica de uma carência sexual'. Está visto que essa carência sexual decorre da inacessibilidade feminina, projetada ou materializada em termos de distância espacial, geográfica" (CAMILO. 2000, p. 48).
} 
racionalização e de sublimação do corpo, tenta alcançar uma suposta pacificação dos desejos, retirando-se a um lugar utópico, a uma "Pasárgada" construída na esfera do sonho, fechando-se a uma possibilidade de resolução dos conflitos de natureza sexual na realidade material. O eu lírico reconhece, contudo, que o desejo se consuma somente no corpo, em sua materialidade:

\author{
"Mas como será Fulana, \\ digamos, no seu banheiro? \\ Só de pensar em seu corpo \\ o meu se punge... Pois sim. \\ Porque preciso do corpo \\ para mendigar Fulana, \\ rogar-lhe que pise em mim, \\ que me maltrate... Assim não."
}

De forma paradoxal, o eu aceita ser e não ser maltratado por Fulana. De um lado, talvez, por querer recusar essa submissão ao corpo; de outro, por reconhecer que o prazer do jogo erótico ganharia intensidade pela perversão. Ao perceber esse conflito entre idealização do desejo e sua realidade corpórea, o eu lírico assume uma postura indagadora, buscando compreendê-lo, enxergálo. Mas ainda se vê sozinho, inocente, criança, preso ao seu passado de medos, submetido à figura de Fulana enquanto fantasma, personagem ou inspiração literária, que o amedronta na rua. E passa a andar pela cidade perguntando por seu paradeiro, mas as respostas são sempre negativas.

Essa trajetória é fundamental para a compreensão de que Fulana se resume a um "talvez"; que o seu sorriso é como um anúncio midiático, irreal; que a sua natureza, semelhante à do mito, o esfaqueia, devido à impossibilidade de ser solucionada, controlada. Essa impotência gera-lhe uma reação de desespero, uma morte, um surto, e assim quer mostrar-se sujo para ela, agredi-la. Mas adquire consciência de que atingi-la é atingir-se a si mesmo, na medida em que Fulana simboliza o seu próprio desejo: 
"Mas não quero nada disso.

Para que chatear Fulana?

Pancada na sua nuca

na minha é que vai doer.

E daí não sou criança."

Assim, o processo de compreensão da natureza ambígua do desejo configura uma espécie de 'rito de passagem' ou de 'processo de individuação' do eu lírico, que então deixa a infância e ingressa na idade da consciência adulta.

Vale lembrar que a temática da relação conflituosa entre uma ideia de sujeito e corpo atravessa a obra poética de Drummond. No poema "Contradições do corpo", da coletânea Corpo (1984) - o qual parece dialogar diretamente com "O mito" -, é abordada novamente essa questão, de modo que o sujeito já se mostra mais experiente para lidar com suas pulsões, que, entretanto, nunca se aplacam:

"Meu corpo ordena que eu saia

em busca do que não quero,

e me nega, ao se afirmar

como senhor do meu Eu

convertido em cão servil.

Meu prazer mais refinado

não sou eu quem vai senti-lo.

É ele, por mim, rapace,

e dá mastigados restos

à minha fome absoluta.

Se tento dele afastar-me,

por abstração ignorá-lo,

volta a mim, com todo o peso

de sua carne poluída, 
seu tédio, seu desconforto.

Quero romper com meu corpo,

quero enfrentá-lo, acusá-lo,

por abolir minha essência,

mas ele sequer me escuta

e vai pelo rumo oposto.

Já premido por seu pulso

de inquebrantável rigor,

não sou mais quem dantes era:

com volúpia dirigida,

saio a bailar com meu corpo."

No poema acima é retratada a relação paradoxal entre a ideia de um "Eu" e o corpo. Este é um lugar a que o sujeito está irremediavelmente condenado, um lugar absoluto onde o "Eu" se corporiza. Tentando apagá-lo, o sujeito buscaria um lugar utópico incorpóreo, abstrato. Mas o corpo não se deixa sujeitar, tendo soberania em sua permanência. Além de ligeiro e transparente, o corpo pode se fazer doente, máquina arruinada e ardilosa, sobrecarregando o "Eu" de males. Visível e penetrável, o corpo é também opaco, incompreensível, espécie de fantasma que só pode ser visto no espelho, em fragmentos. A "madureza", porém, parece ter contido o impulso utópico do sujeito de querer volatilizar o corpo a todo instante, alcançando-se uma espécie de 'harmonia dançante' na relação do "Eu" com o desejo inabalável, que é do corpo.

Mas no poema "O mito", depois da longa procura por Fulana, a possibilidade de sublimação do conflito entre o eu e o desejo só se dá por meio da construção de um espaço utópico imaterial, o poema. O eu lírico conduz sua volúpia para fora do corpo, e por meio de um procedimento sacrifical de autoimolação, a demonstrar que ainda é vítima de sua carnalidade, o que fragiliza a ideia de uma racionalidade vitoriosa: 


\author{
"Mudo-lhe o nome; recorto-lhe \\ um traje de transparência; \\ já perde a carência humana; \\ e bato-a; de tirar sangue. \\ E vadeamos a ciência, \\ mar de hipóteses. A lua \\ fica sendo nosso esquema \\ de um território mais justo. \\ E colocamos os dados \\ de um mundo sem classe e imposto; \\ e nesse mundo instalamos \\ os nossos irmãos vingados. \\ E nessa fase gloriosa, \\ de contradições extintas, \\ eu e Fulana, abrasados, \\ queremos... que mais queremos? \\ E digo a Fulana: Amiga, \\ afinal nos compreendemos. \\ Já não sofro, já não brilhas, \\ mas somos a mesma coisa. \\ (Uma coisa tão diversa \\ da que pensava que fossemos.)"
}

Seguindo um exercício violento de abstração, o sujeito e Fulana passariam a conviver numa outra atmosfera, mítica, imaterial, sob o sistema da lua: símbolo dos ritmos biológicos, da morte e renascimento, do eterno retorno, e de um lugar fora da terra, sem o peso da gravidade e dos conflitos humanos; ou seja, um espaço de fuga. Lá, seriam saciados os desejos sexuais do eu - os corpos ardendo em brasas - e extintas as contradições, não mais prevalecendo o ritmo mecanicista 
do mundo capitalista, ou seja, uma 'utopia sacrificial'. Pois como num lugar de pura abstração se resolveriam as questões do desejo, que são totalmente vinculadas ao corpo $?^{44}$

Segundo George Bataille, a visão cíclica de mundo pressupõe a identificação entre o sacrifício e a união erótica, na medida em que esta sempre se abre à violência, de modo que o ser violado é desagregado, perdendo a barreira que o separava de seu amante:

“O sacrifício, se ele é uma transgressão desejada, é a ação deliberada cujo fim é a súbita mudança do ser que dele é a vítima. Esse ser foi morto. Antes de ter sido morto, ele estava encerrado na particularidade individual. (...) sua existência era, então, descontínua. Mas, esse ser, na morte, é reconduzido à continuidade do ser, à ausência de particularidade. Essa ação violenta, que priva a vítima de seu caráter limitado e confere-lhe o ilimitado, o infinito que pertence à esfera sagrada, é desejada até as últimas conseqüências. Ela é desejada como a ação daquele que desnuda a sua vítima que ele deseja e quer penetrar. $\mathrm{O}$ amante não desagrega menos a mulher amada que aquele que sacrifica de maneira sangrenta o homem ou o animal imolado. A mulher nas mãos daquele que a arrebata é despossuída de seu ser. Ela perde, juntamente com seu pudor, essa barreira firme que, separando-o do outro, tornava-a impenetrável: bruscamente ela se abre à violência do jogo sexual desencadeado nos órgãos de reprodução, ela se abre à violência impessoal que a invade de fora." (BATAILLE. 2004, p. 141)

Por meio de uma autoimolação simbólica do corpo, o eu lírico de "O mito" é conduzido para um lugar alheio à realidade, onde o principal paradigma de um espaço para a comunhão com as pessoas, a 'cidade', é abolido. Deste modo, apesar de se mostrar num estágio à frente do movimento evasionista a meio do caminho de Brejo das almas - ainda decorrente da indecisão ideológica de Drummond, conforme Vagner Camilo -, mesmo porque o poeta, agora, já se posicionou em favor da esquerda política, fica patente que a solução transcendente que se dá à

\footnotetext{
${ }^{44}$ Na já mencionada entrevista a Maria Lucia do Pazo Ferreira, Drummond fala sobre a impossibilidade de se experimentar um amor "tranquilo, celestial": "A gente procura o amor como fonte de realização plena, evidentemente. Mas está mais do que provado que essa realização nunca é desacompanhada de grande tremores de terra, de grandes convulsões, e nós sabemos o preço disso, porque há uma história que, dependendo da nossa experiência - ela vem nos livros, nas óperas, na pintura - mostra as tristezas do amor. É uma procura talvez masoquista, mas que faz parte da natureza humana. Não creio que alguém aspirasse a um amor puramente tranquilo, celestial, mesmo porque na prática, está demonstrado que é impossivel" (PAZO FERREIRA. 1992. p. 330).
} 
problemática do desejo acaba passando necessariamente pela violência, já que o impulso desejante do corpo é "de inquebrantável rigor" (“Contradições do corpo”), ou seja, insolúvel.

Assim, a solução utópica de "O mito" retoma em certa medida a noção de amor dos poetas provençais: amor que alia instinto a inteligência, na medida em que o processo de tomada de consciência faz com que o sujeito deixe de agir como joguete das ilusões provenientes tanto do mundo exterior quanto da subjetividade. Mas o registro do modo violento por que isso se dá acaba enfatizando a impossibilidade de se resolver o impasse do desejo no poema, que se torna um espaço de evasão.

Quanto à estrutura formal, também parece haver nela a retomada de procedimentos da tradição medieval, a fim de subverter o que elas representam. Pode-se notar os versos em redondilha maior distribuídos em quadras, arranjo usual do cancioneiro popular da Idade Média, assim como a longa extensão do poema, a qual rompe com a ideia de que o poema moderno deveria ser sintético. Com relação à temática, há um movimento contrário à concepção medieval hierárquica da sociedade, na medida em que é projetado "um mundo sem classe e imposto", e existe ainda o rompimento com uma ideia de vassalagem amorosa, própria do amor cortês, já que os amantes se poriam em condições de igualdade na relação alcançada.

A resolução do jogo erótico entre o sujeito poético e Fulana pode metaforizar ainda a conjunção dos elementos masculino e feminino, denominado nos tratados de alquimia medieval como "coniunctio" ou "coitus". Segundo Jung, seria esse o estágio final de um "processo de individuação', através do qual o sujeito vai se libertando de valores tradicionais masculinos, vinculados ao intelectualismo e ao racionalismo, à proporção em que se aprofunda no contato com o próprio inconsciente, que representaria a "anima", ou seja, o elemento feminino da personalidade (JUNG. 2011a, pp. 61 e 247). Com essa conjunção de opostos, os dois polos se ajustam e criam uma forma superior, alcançando o "estado lunar ou de prata, que ainda deve alçar-se ao estado solar" (idem, p. 248), estado esse que, aliás, se ajusta à atmosfera criada por estes versos de "O mito": "A lua / fica sendo nosso esquema / de um território mais justo". E os versos finais, "Já não 
sofro, já não brilhas / mas somos a mesma coisa. // (Uma coisa tão diversa / da que pensava que

fôssemos)", podem ser iluminados também pelo simbolismo que entende o amor como algo que mata e vivifica, como se lê neste trecho de Agostinho, traduzido por Jung: "O amor mata o que éramos, a fim de que surja o que não éramos; o amor é para nós como uma morte” (2011b, p. $263) .^{45}$

A tensão erótica entre o sujeito e o seu objeto de desejo, bem como a sua trajetória de caminhar pela cidade se aproximando de pessoas diversas, expressam ainda um movimento de socialização que atravessa todos os poemas de A Rosa do Povo. Como já dissemos, existe no livro a intenção de o poeta sair de sua posição de autonomia e de passar a agir como artista engajado, produzindo uma poesia que o permitisse comunicar-se com um maior número de leitores. ${ }^{46}$

Seguindo o movimento acima descrito, mencionamos, para gerar novas questões, a reflexão de Reich sobre a inibição sexual e os prejuízos que dela decorrem. Entende este que o sujeito reprimido sexualmente acaba por se retrair em seu círculo familiar, deixando de experimentar diferentes formas de contato com o mundo que seriam naturalmente decorrentes da satisfação de suas pulsões sexuais:

“Os desejos sexuais impelem naturalmente os seres humanos para toda espécie de contatos com o mundo, para um contato íntimo com o mundo em todas as suas formas. Sendo estes contatos reprimidos, resta apenas a possibilidade de agir dentro do limitado círculo familiar. A inibição sexual constitui a base tanto do encerramento dos indivíduos no seu círculo familiar como na consciência pessoal individual. Deve-se ter presente que os tipos de comportamento metafísico, individual e sentimental-familiar não são mais do que aspectos diferentes do mesmo processo de negação sexual, ao passo que o modo de pensar voltado para a realidade, não místico, se identifica com relações familiares descontraídas e

\footnotetext{
${ }^{45}$ Note-se que só depois de consumada a união, é que os dois últimos versos deixam de ser arranjados em quarteto e são dispostos num dístico - palavra que, além de designar estrofe mínima, compreende o significado de uma sentença que resume um ideal: "máxima expressa em dois versos; lema, divisa" (Dicionário Houaiss, 2003).

${ }^{46}$ Nesse sentido, vale notar um trecho da série de entrevistas concedidas por Drummond já no final de sua vida à amiga Lya Cavalcanti, repórter da Rádio Ministério da Educação e Cultura, em que fala acerca da importância da aproximação entre indivíduos por meio da literatura: "O que há de mais importante na literatura, sabe? é a aproximação, a comunhão que ela estabelece entre seres humanos, mesmo à distância, mesmo entre mortos e vivos" (CAVALCANTI. 1987, p. 58).
} 
com uma atitude, no mínimo, de indiferença para com a ideologia sexual ascética." (REICH. 2001, p. 53-54)

Seria interessante considerar essa relação de causalidade entre a realização da sexualidade e a socialização do indivíduo para tentarmos compreender as transformações por que passa o eu lírico em "O mito", depois de enfrentadas racionalmente as suas pulsões e transportadas a uma nova ordem social, sem classes nem impostos, em que as contradições estivessem supostamente extintas, numa utopia. Mas, no caso deste poema, quando a questão social se emaranha na libido e no tabu, o procedimento da razão seria ainda a melhor forma de 'revolução'? ${ }^{47}$

Tal qual um mito, a composição revolve-se sobre si mesma, e as contradições do eu poético, que envolvem desejo e brutalidade, assim como as contradições sociais, permanecem não totalmente passíveis de resolução, o que acaba por gerar a qualidade ambígua do paraíso projetado nas estrofes finais, que parece antes um espaço de evasão.

O poema "O mito" encerra o caráter ambíguo que o seu título enuncia, apresentando diversas camadas semânticas que não se esgotam em si mesmas. Expõe simultaneamente o jogo erótico e sua violência; a dominação exercida pelos valores ideológicos da classe burguesa detentora dos meios de produção; o processo de conscientização do indivíduo acerca da figura idealizada (e por isso mesmo oprimente) de seu objeto de desejo; o ritual de sacrifício de Fulana enquanto metáfora de uma autoimolação do corpo; a recusa da ordem social estabelecida. De todo modo, o poema encerra a visão de Drummond acerca da soberania do desejo: irredutível não só à racionalização que o mundo pressupõe, mas também insolúvel no âmbito do poema.

\footnotetext{
47 O poema "Carta a Tatiana Iácovleva", de Maiakóvski, é um exemplo de texto que também aborda o tema da inacessibilidade da mulher em razão da divisão de classes da sociedade capitalista, articulando a iminência de uma tomada de Paris pelos comunistas à conquista da mulher desejada - deixando subentendido, inclusive, a possibilidade de que esta poderia ser tomada contra sua vontade, ou seja, através da violência.
} 


\section{Encontro com o coletivo}

\subsection{Visão local: "Morte do leiteiro"}

Na apresentação à coletânea Poemas Ingleses de Guerra (1942), organizados e traduzidos por Abgar Renault, Drummond sublinha a função do poeta como um "guia" nos grandes momentos de crise da humanidade, ressaltando que, por força da sua "aliança com as palavras", é capaz de exprimir lucidamente os sentimentos e perplexidades humanos, emaranhados numa espécie de 'caos':

"E o que êsse homem comum não pode exprimir, o poeta, mercê de sua aliança com as palavras, e por via de um secreto maquinismo, nos apresenta sob a especie de um concentrado e patético lirismo, não apenas inglês, mas universal e humano. (...) o poeta é um guia firme, que dá gosto seguir. Ele nos salva das pequenas e grandes confusões do momento, nos tira a perplexidade, varre de nós ao mesmo tempo o otimismo e pessimismo circunstanciais. Ensina-nos a considerar a guerra e mesmo a dela participar, sem que nos ternemos simples instrumento de economias em luta; e exige de nós apenas que sejamos realmente solidários com as coisas que amamos: 'as coisas simples pelas quais os homens morrem."”(DRUMMOND DE ANDRADE. In: RENAULT. 1942, p. 3-4)

Nesse trecho é exaltada uma poesia que abranja a um só tempo o dado local e o internacional, o que justifica nossa escolha pela análise, neste capítulo, de um poema referente ao contexto brasileiro, "Morte do leiteiro", e outro de caráter internacionalista, "Carta a Stalingrado".

Discorremos no capítulo anterior sobre o movimento de exploração do eu lírico de questões que se explicitavam mais como de natureza individual (embora implicitamente estivessem em constante relação com temas coletivos), tais como a memória da infância, o procedimento de 
miniaturização, o desejo, indicando que, a partir da conscientização dos conteúdos e recalques particulares, o sujeito se tornou mais apto para ampliar sua visada poética sobre o social. Daí pretendermos neste novo capítulo analisar mais detidamente os poemas "Morte do leiteiro" e "Carta a Stalingrado", cujo foco recai especialmente sobre assuntos ligados ao tempo histórico e à coletividade, como o conflito de classes, a função da ordem e da lei na sociedade brasileira, a guerra generalizada e suas possíveis consequências no plano social. Não deixaremos de observar nesses poemas, contudo, a camada simbólica subjacente.

O que podemos compreender, numa primeira leitura do poema "Morte do leiteiro", é o uso do episódio de um assassinato como alegoria de um conflito de classes. A estrofe de abertura é composta por três sentenças de dois versos, as quais enunciam as legendas que justificariam a exploração do trabalhador destituído de bens, e a impunidade do proprietário que o explora e que lhe retira a vida, sendo feita, na estrofe seguinte, uma divisão de certa forma maniqueísta entre a substância boa que é o leite, e as pessoas ruins que a recebem, o que até mesmo sugere certo extremismo ideológico:

\section{“MORTE DO LEITEIRO}

Há pouco leite no país, é preciso entregá-lo cedo.

Há muita sede no país, é preciso entregá-lo cedo.

5 Há no país uma legenda, que ladrão se mata com tiro.

Então o moço que é leiteiro de madrugada com sua lata sai correndo e distribuindo

10 leite bom para gente ruim. Sua lata, suas garrafas, e seus sapatos de borracha vão dizendo aos homens no sono 
que alguém acordou cedinho

15 e veio do último subúrbio

trazer o leite mais frio

e mais alvo da melhor vaca

para todos criarem força

na luta brava da cidade.

20 Na mão a garrafa branca

não tem tempo de dizer

as coisas que lhe atribuo

nem o moço leiteiro ignaro,

morador na Rua Namur,

25 empregado no entreposto,

com 21 anos de idade,

sabe lá o que seja impulso

de humana compreensão.

E já que tem pressa, o corpo

30 vai deixando à beira das casas

uma apenas mercadoria.

E como a porta dos fundos

também escondesse gente

que aspira ao pouco de leite

35 disponível em nosso tempo,

avancemos por esse beco,

peguemos o corredor,

depositemos o litro...

Sem fazer barulho, é claro,

40 que barulho nada resolve.

Meu leiteiro tão sutil,

de passo maneiro e leve,

antes desliza que marcha.

É certo que algum rumor

45 sempre se faz: passo errado,

vaso de flor no caminho,

cão latindo por princípio,

ou um gato quizilento. 
E há sempre um senhor que acorda,

50 resmunga e torna a dormir.

Mas este acordou em pânico

(ladrões infestam o bairro),

não quis saber de mais nada.

O revólver da gaveta

55 saltou para sua mão.

Ladrão? se pega com tiro.

Os tiros na madrugada

liquidaram meu leiteiro.

Se era noivo, se era virgem,

60 se era alegre, se era bom,

não sei,

é tarde para saber.

Mas o homem perdeu o sono

de todo, e foge pra rua.

65 Meu Deus, matei um inocente.

Bala que mata gatuno

também serve pra furtar

a vida de nosso irmão.

Quem quiser que chame médico,

70 polícia não bota a mão

neste filho de meu pai.

Está salva a propriedade.

A noite geral prossegue,

a manhã custa a chegar,

75 mas o leiteiro

estatelado, ao relento,

perdeu a pressa que tinha.

Da garrafa estilhaçada,

no ladrilho já sereno

80 escorre uma coisa espessa

que é leite, sangue... não sei.

Por entre objetos confusos, 
mal redimidos da noite, duas cores se procuram,

85 suavemente se tocam, amorosamente se enlaçam, formando um terceiro tom a que chamamos aurora."

O relato do cotidiano de um leiteiro que sai diariamente do subúrbio para ir ao centro da cidade distribuir um alimento essencial como o leite; a exposição minuciosa de características do seu ofício e de sua personalidade, demonstram a materialização, no poema, dos princípios de uma poesia social que Drummond veio a pleitear expressamente na crônica "Trabalhador e poesia", de Passeios na Ilha, publicada pela primeira vez no suplemento literário de A Manhã de setembro de 1949, ou seja, posteriormente à publicação de A Rosa do Povo.

Na mencionada crônica, o poeta mineiro aborda a produção da poesia social no Brasil. Em primeiro lugar, ressalta a escassez de poemas que se debrucem sobre as especificidades das técnicas de trabalho e da personalidade de cada tipo de trabalhador, ficando, na sua maioria, restritos à declaração de princípios. Ou seja, os poetas continuavam a cantar a si mesmos, como profetas de novos tempos, de modo que a sua atitude de apenas enunciar sua revolta, e de pintar vagamente um futuro possível de justiça, os eximisse de analisar as relações de trabalho e as condições de vida no campo e na cidade. Assim, ainda sob a influência de um romantismo social, trabalhavam sempre com uma espécie simbólica de trabalhador, deixando de particularizá-lo. De todo modo, Drummond reconhece o valor de poemas simbolistas como "Numa forja", de Augusto dos Anjos, que, mesmo não se atendo à questão social, visualiza de maneira admirável o processo da fundição, revelando as energias ocultas na matéria.

Em segundo lugar, fala sobre a necessidade de incorporar à poesia nacional a produção dos poetas modernistas iniciada por Manuel Bandeira, que passaram a dar preferência a temas brasileiros e à vida dos trabalhadores rurais ou urbanos, abandonando o tom retórico e alusivo a um trabalhador simbólico, e enfatizando a noção de solidariedade no trabalhador brasileiro real. 
Vale notar, a propósito, que, noutra crônica de Passeios na ilha, "Contemplação de Ouro Preto", Drummond descreve a etapa inicial de sua viagem às Minas Gerais, que é atravessar de trem o subúrbio do Rio de Janeiro, o qual retrata um dos lados mais obscuros e desumanos da vida do trabalhador na grande metrópole:

"É o correr das composições elétricas levando cachos humanos entre as folhas das portas, fora das portas, agarrados a qualquer saliência da carapaça metálica ou mesmo a nada. É a multidão dos que regressam de um dia de trabalho no Rio. Não há visão mais impressionante das imperfeições e incoerências de uma grande cidade, do que esta, a repetirse inexoravelmente todas as tardes, e pela noite adentro. Homens e mulheres estão exaustos, mas a labuta do dia não foi bastante. Conquistar espaço no trem elétrico exige um esforço suplementar, com a energia do desespero, e esse lugar às vezes se paga com a vida." (DRUMMOND DE ANDRADE. 2011b, p. 62)

Nesse texto é pintado um quadro pungente do fluxo diário de pessoas pobres no transporte público carioca, que as sujeitam a condições deploráveis, inferiores a do carregamento de coisas e animais: "No interior das jaulas não há leitura possível, nem conversa, nem namoro nenhum, nem sentimento da qualidade especial do ser humano, que subsista. Os cargueiros de minério ou gado não viajam tão cheios. E os bois devem morrer menos, no percurso" (idem, p. 63). Como já dissemos, são abordadas questões relativas à miséria na sociedade urbana, tanto no poema “Anoitecer”, "só multidões compactas / escorrendo exaustas / como espesso óleo / que impregna o lajedo", quanto em "Morte do leiteiro", sendo evidente a atualidade desses textos. Pois vemos até hoje o mesmo espetáculo detestável: a maior parte da população das metrópoles perdendo horas dentro de ônibus e trens, completamente lotados e presos em congestionamentos, enquanto grandes incorporadoras privadas se revoltam contra novos planos diretores urbanísticos, que prevejam a limitação drástica de vagas de garagem nos futuros edifícios comerciais e residenciais voltados às classes média e alta, medida essa que visaria favorecer as condições do transporte público caótico. 
Ao narrar o episódio do assassinato do leiteiro, o poema atenta para a função da ordem e da lei na sociedade brasileira, que privilegiam a salvaguarda da propriedade privada em detrimento da garantia de direitos humanos fundamentais, como a vida. Na ocasião em que foi escrito o poema, estava em vigor no Brasil não só a Constituição Federal do Estado Novo - também conhecida por “Constituição Polaca”, por ter sido inspirada na Constituição autoritária da Polônia -, outorgada por Getulio Vargas a 10 de novembro de 1937, no mesmo dia em que implantou o regime ditatorial, concentrando na sua pessoa todos os poderes de Estado. Como também o Código Civil de 1916, conhecido por seu caráter patrimonialista privado, que lançava sempre para um plano secundário os direitos públicos.

Assim, o gesto do proprietário burguês de "Morte do leiteiro", de tentar defender por conta própria o seu imóvel, valendo-se inclusive de arma de fogo, certamente não se afigurava algo incomum no contexto da época, cuja legenda, apontada já na primeira estrofe, era "que ladrão se mata com tiro", muito embora a lei proibisse que os "atos de defesa da posse" implicassem em violência. ${ }^{48}$ Ou seja, o proprietário jamais poderia tirar a vida de alguém que lhe estivesse apenas roubando os bens, só podendo valer-se do direito à "legítima defesa", que inclui um contra-ataque violento ao agressor, caso sua vida estivesse de fato correndo perigo.

A referência em "Morte do leiteiro" ao discurso patrimonialista de direita parece criticar também uma aparente crença na impunidade, como se a lei não valesse de forma igualitária para ricos e pobres. Pois nestes versos é exposta a questão da desobediência legal, ou seja, a consciência de que a salvaguarda da propriedade privada pode se sobrepor aos direitos do cidadão:

“Ladrão? se pega com tiro.

Os tiros na madrugada

liquidaram meu leiteiro.

\footnotetext{
${ }^{48}$ Transcrevemos o artigo do Código Civil de 1916, que trata dos limites do indivíduo para a defesa da posse de um bem particular: "Art. 502. O possuidor turbado, ou esbulhado, poderá manter-se ou restituir-se por sua própria força, contanto que o faça logo. Parágrafo único. Os atos de defesa, ou de desforço, não podem ir além do indispensável à manutenção ou restituição da posse."
} 
Se era noivo, se era virgem,

se era alegre, se era bom,

não sei,

é tarde para saber.

Mas o homem perdeu o sono

de todo, e foge pra rua.

Meu Deus, matei um inocente.

Bala que mata gatuno

também serve para furtar

a vida de nosso irmão.

Quem quiser que chame médico,

polícia não bota mão

neste filho de meu pai.

Está salva a propriedade.

A noite geral prossegue,

a manhã custa a chegar,

mas o leiteiro

estatelado ao relento,

perdeu a pressa que tinha."

Uma espécie de culpa cristã assola o proprietário que, mostrando-se arrependido pelo crime, perde a impassibilidade do sono da esfera privada e "foge pra rua", lugar público em que se operaria uma transformação em sua atitude individualista. Mas, em seguida, é exposta a ambiguidade desse gesto, na medida em que o assassino se recusa a ser penalizado (e por consequência transformado) pelo cometimento do crime, ao dizer "polícia não bota a mão / neste filho de meи pai", ou seja, o pronome possessivo "meu" mostra que tanto a noção de Deus como a lei estariam a serviço dos interesses do indivíduo de posses, conservando-se o contexto negativo de "noite geral" e de supremacia do patrimonialismo privado. Esse aspecto narrativo do poema, no qual são utilizadas técnicas como a do discurso livre indireto, em que a fala da personagem do proprietário se intercala à fala do eu lírico narrador, acaba por atribuir um tom mais documental à 
composição, como se o ato de dar voz à personagem, traduzisse uma noção de testemunho do crime.

É exposto ainda o estado de alienação do leiteiro em relação ao próprio discurso crítico que se refere a ele, questão semelhante à do poema "Operário no mar", de Sentimento do Mundo, em que o eu lírico acompanha, à distância, a caminhada de um trabalhador pela cidade, discorrendo sobre a sua função social, "O operário não lhe sobra tempo de perceber que eles levam e trazem mensagens, que contam da Rússia, do Araguaia, dos Estados Unidos" - embora neste último poema, ainda se veja a referência a um trabalhador indeterminado, justamente o que Drummond vem a criticar na crônica "Trabalhador e poesia" (1949).

Como se sabe, a lógica da produtividade do sistema capitalista expropria do trabalhador o tempo que lhe seria necessário para conscientizar-se do seu ofício. Assim, passa a exercer um trabalho abstrato, automático, não tendo consciência de seu conteúdo real, tampouco de seu “caráter útil”, como o explica Jorge Grespan, citando Marx:

"O trabalho abstrato se define, portanto, como gasto fisiológico-mental de energia humana 'sem consideração à forma de seu dispêndio'; abstrato, na medida em que nele se prescindem das qualidades concretas que diferenciam os diversos trabalhos de acordo com seu 'caráter útil'”. (GRESPAN. 2012, p. 52)

Pela redução da qualidade de todos os trabalhos a um denominador comum, isto é, ao tempo de trabalho humano dispendido para a produção de mercadorias, ingressa o sujeito numa espécie de alienação quanto ao processo, à forma, à utilidade real e simbólica de seu ofício e dos produtos dele gerados.

Na década de 40, Carlos Drummond manifestava claramente a sua inclinação pela 'solução do comunismo' em contraposição a uma “ação católica, fascista e organizada em 'Defesa do Ocidente" (GLEDSON. 1982, p. 90), retomando-se aqui os termos da citada entrevista concedida pelo poeta ao jornal A Pátria, em 1931, transcrita no estudo de Gledson. Nesse sentido, leia-se 
trecho de resenha de Drummond sobre uma coletânea de ensaios marxistas publicados no Brasil em 1945, pela Editorial Calvino, transcrito em Os sapatos de Orfeu, de José Maria Cançado: “O marxismo permite ao artista elevar-se a um nível superior, atingir a compreensão do movimento histórico, sentir o conjunto dos fenômenos, penetrar até as engrenagens mais secretas do mecanismo da sociedade" (DRUMMOND DE ANDRADE. In: CANÇADO. 1993, p. 196). Assim, Drummond já empregava termos marxistas como "mercadoria", que, "Em morte do leiteiro", remete a um dos aspectos desenvolvidos por Marx acerca da sociedade burguesa, a saber, o fetichismo da mercadoria, pelo qual as relações sociais entre os indivíduos são convertidas em relações entre coisas, avaliadas enquanto valor de troca, e destituídas de seu valor útil e simbólico, como o explica Jorge Grespan:

"Como os trabalhos são privados e autonomizados, as 'relações de produção' entre os membros desta sociedade escapam do 'controle do seu fazer individual', adquirindo uma 'figura objetiva' - exterior a eles e coisificada - na forma-mercadoria. A troca é a instância em que se manifestam as 'relações de produção', que fora dela se obscurecem na autonomia dos trabalhos privados." (GRESPAN. 2012, p. 49)

Como os meios de produção são fornecidos pelos proprietários capitalistas, o próprio trabalho se presta à coisificação, pois está isolado, solto, alienado. De modo que o despossuído só pode vender a sua própria força de trabalho, que é a origem da mercadoria, convertendo-se ela também em mercadoria. Para Marx, o processo de exploração da força do trabalho é uma sorte do capitalista, que, ao pagar um salário supostamente condigno com o esforço do trabalhador, acaba por gastar, com a aquisição da mercadoria (que abrange esse dispêndio de tempo do assalariado), muito menos que o valor real desse trabalho.

O estado de ansiedade produtiva, de cisão entre consciência e corpo, de inconsciência no exercício do trabalho diário, de conversão de todas as coisas em mercadorias, são explicitados nesta estrofe de "Morte do leiteiro": 


\begin{abstract}
"Na mão a garrafa branca
não tem tempo de dizer

as coisas que lhe atribuo

nem o moço leiteiro ignaro,

morador na Rua Namur,

empregado no entreposto,

com 21 anos de idade,

sabe lá o que seja impulso

de humana compreensão.

E já que tem pressa, o corpo

vai deixando à beira das casas

uma apenas mercadoria."
\end{abstract}

Mesmo no seu alheamento, é atribuída ao leiteiro a característica de um intermediário (“empregado no entreposto"), responsável pela entrega diária de uma substância alva - que metaforiza a própria poesia -, assumindo um caráter até mesmo subversivo na distribuição da mercadoria àqueles que de fato a almejam: "E como a porta dos fundos / também escondesse gente / que aspira ao pouco de leite / disponível em nosso tempo". Assim, é indicada no texto uma prática real que costumava acontecer naquela época, em que os poemas de Drummond, datilografados em folhas avulsas, eram distribuídos entre leitores como se fossem mensagens clandestinas. ${ }^{49}$

A característica medial do leiteiro é acentuada pelo fato de ser ele morador na Rua Namur. Assim, a alegoria de um conflito social partindo de um drama cotidiano da sociedade brasileira, e que guardasse relação exclusiva com o processo de modernização do Brasil, parece ampliar-se também para o contexto internacional, com a referência a Namur. ${ }^{50}$ Nisso se vê a faculdade do

\footnotetext{
${ }^{49}$ Esse fato é contado pelo biografista de Drummond, José Maria Cançado: "Na verdade, a maioria dos poemas desta época têm, além do sopro épico, um quê de cabograma noturno, de emissão radiofônica clandestina, de estímulo e palavra de ordem para combatentes. Assim, por exemplo, com poemas como Telegrama de Moscou, ou o arrebatado Carta a Stalingrado. Ou então o Mas viveremos, que na verdade chamava-se originariamente A morte da III Internacional, e foi mandado para São Paulo, até chegar às mãos de Antonio Candido, que fez o poema circular clandestinamente nos meios antifascistas." (CANÇADO. 1993, p. 177-178)

${ }^{50}$ Além de ser uma rua do subúrbio do Rio de Janeiro, Namur é uma cidade da região da Valônia, no sul da Bélgica, situando-se exatamente no ponto de confluência dos rios Sambre e Meuse. A sua história remonta ao segundo milênio
} 
poeta em extrair, dos acontecimentos em geral, um material humano profundo que possa ser convertido em expressão poética. Antonio Candido sublinha, a esse respeito, que o que difere Drummond dos outros modernistas, os quais tentam fixar o cotidiano para alcançar um momento poético autossuficiente, é o fato de ele proceder "a uma fecundação e a uma extensão do fato, para chegar a uma discreta epopeia da vida contemporânea. Isto talvez se ligue à capacidade de injetar fantasia nas coisas banais" (CANDIDO. 2004, p. 82).

Se pensarmos em termos de epopeia, retomando a definição de Kayser acerca da atitude lírica da enunciação, em que o sujeito poético mantém uma certa atitude épica, postando-se frente ao acontecimento, para apreendê-lo e exprimi-lo, mas resguardando boa parte de seu caráter objetivo, é possível notar em "Morte do leiteiro" certa despersonalização na dicção do eu lírico, o que lhe atribui a qualidade de um poema enunciativo. De todo modo, é interessante notar que ao longo da composição o eu faz algumas marcações apostróficas, interpelando o leitor a acompanhálo na narrativa da entrega do leite, "avancemos por esse beco, / peguemos o corredor"; bem como utiliza pronomes possessivos na primeira pessoa, ressaltando o caráter ficcional e subjetivo da personagem do leiteiro, "as coisas que lhe atribuo", "Meu leiteiro tão sutil", "liquidaram meu leiteiro". Assim, pode-se notar que esse poema alegórico acumula uma série de camadas semânticas que se vão desvelando ao seu processo de análise.

Para os românticos, que eram partidários do orgânico e do mito, o caráter racionalista e frio do discurso alegórico, que se faz por uma série de momentos textuais, partindo do particular para o universal, é uma espécie de antítese do discurso simbólico, que contem e expressa em si o geral, de forma imediata, caracterizando-se como o universal no elemento particular. Walter Benjamin, contudo, parece desfazer essa avaliação negativa proveniente do Romantismo, atribuindo à alegoria a mesma força do símbolo, na medida em que nela, "cada personagem, cada coisa, cada relação

a.C., tendo sido inicialmente um entreposto comercial dos celtas, conhecidos como os introdutores da metalurgia na Europa, dando origem à idade do ferro no continente. $\mathrm{O}$ vilarejo foi tomado depois pelos romanos e, durante a Idade Média, foi construída no topo da montanha uma fortaleza existente até hoje, da qual se pode avistar tanto a cidade quanto o vale pelo qual correm e se encontram os rios. Namur sempre foi objeto de disputa entre povos inimigos, tendo sido invadida pelos alemães na Primeira Guerra (1914), que queriam utilizar o vale do Meuse como rota para a França. Também foi palco da Batalha de Ardenas, em 1940, e da Batalha de Bulge, em 1944, durante a Segunda Guerra. 
pode significar qualquer outra coisa" (BENJAMIN. 2011, p. 186), sendo simultaneamente convenção estilística fria e expressão de matéria eruptiva e enigmática.

A estrofe final de "Morte do leiteiro" parece conferir a todo o poema uma amplitude simbólica de início insuspeitada. Nela é feita a descrição da confluência lenta entre o leite e o sangue que escorrem da garrafa espedaçada e do corpo alvejado, gerando a imagem de um líquido espesso:

\footnotetext{
"Da garrafa estilhaçada, no ladrilho já sereno escorre uma coisa espessa que é leite, sangue... não sei. Por entre objetos confusos, mal redimidos da noite, duas cores se procuram, suavemente se tocam, amorosamente se enlaçam, formando um terceiro tom a que chamamos aurora."
}

Pensemos nessa imagem em movimento: o leite e o sangue se fundindo sobre o ladrilho, o qual parece metaforizar o pavimento do corredor de acesso ou do alpendre da casa do proprietário burguês. As substâncias de natureza orgânica são depois equiparadas a cores - cujo radical cor remete também a coração -, as quais se aproximam como dois corpos numa dança de acasalamento, até formar-se o tom da aurora, a remeter à ideia de superação da noite. Isso, aliás, reforçaria o argumento acerca do caráter processual de $A$ Rosa do Povo, na medida em que as imagens acima parecem contrapor-se à imagem formada no poema “Anoitecer", também de escorrimento de um líquido sobre o solo, utilizando o mesmo verbo "escorrer" e o mesmo adjetivo "espesso": 


$$
\begin{aligned}
& \text { “só multidões compactas } \\
& \text { escorrendo exaustas } \\
& \text { como espesso óleo } \\
& \text { que impregna o lajedo;" }
\end{aligned}
$$

O momento aqui é a do cair da noite, a do começo do processo de dissolução das estruturas e valores solidificados no "nosso tempo", inexistindo ainda a figura individualizada de um leiteiro, mas apenas a de multidões amorfas que são comparadas ao óleo.

Para sublinhar essa evidente diferenciação no livro entre as fases do anoitecer e da aurora, nos deparamos, em "Morte do leiteiro", com a imagem de um líquido espesso, que une a cor branca do leite ao vermelho do sangue, formando um possível líquido rosa, ou mesmo um 'sangue rosa'. Assim, referimo-nos agora ao estudo de C. G. Jung acerca da simbologia do "sangue rosa", a qual parece guardar certa relação com algumas das camadas semânticas de "Morte do leiteiro". Segundo Jung, o "sangue róseo" se origina da mística da rosa, caracterizando-se como uma "natureza vegetal", diferentemente do sangue comum, que se caracteriza como uma "matéria vegetal". Somente um "homem puríssimo", que não fosse alterado por nenhuma influência exterior nem mistura, seria capaz de expelir o "sangue rosa", símbolo de uma substância de caráter salvífico, que vem ao mundo para juntar e tornar completos o indivíduo e a multidão, preservando a harmonia do cosmos:

"Não se trata aqui de modo algum de um Cristo futuro e 'salvador microcosmi', mas de um 'servatur cosmi' (conservador do cosmos) alquimista, da idéia ainda inconsciente de um homem total que deverá realizar o que o sacrifício de Cristo manifestamente deixou incompleto: livrar o mundo do mal. Como o Cristo, ele suará um sangue redentor, mas sendo de 'vegetabili naturae' esse sangue é de 'rosacei coloris' (cor de rosa), não sangue natural (comum), mas um sangue simbólico, uma substância anímica, ilustração de um certo eros que, sob o sinal da rosa, una e torne completos o indivíduo e a multidão, sendo por conseguinte uma panacéia (medicina) e modo de preservação (alexipharmacum)." (JUNG. 2002, p. 288) 
O leiteiro carrega o sangue e o leite, e ao ser assassinado deixa que os dois líquidos escorram no chão e se fundam, para dar início a uma possível união entre indivíduo e coletividade, o que está de certa forma indicado - ainda que de modo ambíguo, como dissemos -, no ato de o proprietário burguês, antes fechado na sua residência - "sob a paz das cortinas / à pálpebra cerrada”, do poema anterior "O elefante" -, fugir para a rua após cometer o assassinato, saindo, assim, de uma esfera de completo adormecimento em relação à alteridade: "Mas o homem perdeu o sono / de todo, e foge pra rua".

Talvez esteja aí o sentido utópico da "aurora", que assume o tom profético de surgimento de um novo tempo e de um novo homem, imagem que remonta não só ao Manifesto Comunista, mas também ao texto bíblico e a diversos textos por ele influenciados ao longo da história. ${ }^{51}$ Vemos aí, portanto, um entrelaçamento das concepções de utopia e apocalipse, comum na obra de certos autores marxistas do século $\mathrm{XX},{ }^{52}$ o que acaba por aparecer também, segundo nossa leitura, em alguns poemas de A Rosa do Povo, como em "Visão 1944", cujos versos finais, "o mundo que se esvai em sujo e sangue, / outro mundo que brota, qual nelumbo", sublinham mais uma vez a questão da transformação do sujeito e da realidade pela violência, como a automutilação ou a autoflagelação simbólicas do sujeito poético, ou pela morte sacrificial, que, em "Morte do leiteiro", impele o proprietário burguês a fugir para a rua, por conta do seu sentimento de culpa pelo assassinato cometido, mas também para evitar a polícia.

De todo modo, não podemos deixar de sublinhar o possível substrato de ironia e de crítica contido nessa alusão à imagem excessivamente radiante da alvorada, surgida logo após o registro de um acontecimento de violência urbana. Pois, como foi observado, a personagem do burguês não é

\footnotetext{
51 A saber: a Aurora consurgens, de São Tomás de Aquino (século XIII); o Rosarium philosophorum, de autor desconhecido (século XVI); Aurora, de Jacob Böhme (século XVII); a Fama Fraternitatis R.C. ou Manifesto da Fraternidade da Mui Louvável Ordem Rosa Cruz, de Johannes Valentinus Andreae (século XVII).

${ }^{52}$ Note-se a dicção apocalíptica no seguinte trecho de Princípio Esperança, de Ernst Bloch, que também faz alusão expressa a uma noção de 'aurora': "E mais tarde nas grandes cidades, com clareza cada vez maior e imbuída do espírito socialista, em união com os trabalhadores, despontou solidamente a aurora que estava guardada na consciência e no tempo" (BLOCH. 2005, p. 118).
} 
tocada pelo acontecimento criminoso, permanecendo inalterada, presa que está a valores capitalistas, como a propriedade privada. Assim, apesar da imagem salvífica do final do poema, o eu lírico parece demonstrar certo ceticismo quanto à possibilidade de transformação do indivíduo burguês - sem interesse pela poesia e pela revisão de sua posição ideológica -, bem como da sociedade em geral, conferindo ambiguidade ao símbolo da aurora, que pode indicar só mais um amanhecer, como qualquer outro.

\subsection{Visão internacional: "Carta a Stalingrado"}

Num contexto de 'guerra global', em que quase todos os Estados do mundo estavam envolvidos com a Segunda Guerra, foi escrito provavelmente em agosto de 1942 o poema "Carta a Stalingrado", conforme nota da recente edição crítica de Alguma poesia a Lição de coisas (DRUMMOND DE ANDRADE. 2012, p. 472), aludindo à missiva na qual Drummond remete a Abgar Renault cópia do poema. Apesar de definido como 'carta', a composição assume o tom de um hino à cidade que resistiu heroicamente à invasão nazista no período de julho de 1942 a fevereiro de 1943. Sendo considerado talvez o conflito armado mais sangrento da história, no qual morreram cerca de duas milhões de pessoas, incluindo soldados e civis, a batalha de Stalingrado configurou um ponto de inflexão decisivo na guerra, impedindo a expansão do Eixo e dando início à contraofensiva soviética, que culminou com a tomada de Berlim pelos russos em 8 maio de 1945.

"Carta a Stalingrado" está inserido num conjunto de cinco poemas de A Rosa do Povo que formam um quadro cronológico da guerra, que, na ocasião, era considerada por Drummond o 'novo' material épico por excelência. ${ }^{53}$ Talvez por isso o poema apresente um tom elevado, comum às narrativas míticas:

\footnotetext{
${ }^{53}$ São eles, na ordem em que aparecem no livro: "Carta a Stalingrado", “Telegrama de Moscou”, "Mas viveremos”, "Visão 1944" e "Com o russo em Berlim".
} 


\section{“CARTA A STALINGRADO}

Stalingrado...

Depois de Madri e de Londres, ainda há grandes cidades!

O mundo não acabou, pois que entre ruínas

outros homens surgem, a face negra de pó e de pólvora,

5

e o hálito selvagem da liberdade

dilata os seus peitos, Stalingrado,

seus peitos que estalam e caem

enquanto outros, vingadores, se elevam.

A poesia fugiu dos livros, agora está nos jornais.

10 Os telegramas de Moscou repetem Homero.

Mas Homero é velho. Os telegramas cantam um mundo novo

que nós, na escuridão, ignorávamos.

Fomos encontrá-lo em ti, cidade destruída,

na paz de tuas ruas mortas mas não conformadas,

15 no teu arquejo de vida mais forte que o estouro das bombas,

na tua fria vontade de resistir.

Saber que resistes.

Que enquanto dormimos, comemos e trabalhamos, resistes.

Que quando abrirmos o jornal pela manhã teu nome (em ouro oculto), estará firme

[no alto da página.

20 Terá custado milhares de homens, tanques e aviões, mas valeu a pena.

Saber que vigias, Stalingrado,

sobre nossas cabeças, nossas prevenções e nossos confusos pensamentos distantes

dá um enorme alento à alma desesperada

e ao coração que duvida.

25 Stalingrado, miserável monte de escombros, entretanto resplandecente!

As belas cidades do mundo contemplam-te em pasmo e silêncio.

Débeis em face do teu pavoroso poder,

mesquinhas no seu esplendor de mármores salvos e rios não profanados,

as pobres e prudentes cidades, outrora gloriosas, entregues sem luta, 
aprendem contigo o gesto de fogo.

Também elas podem esperar.

Stalingrado, quantas esperanças!

Que flores, que cristais e músicas o teu nome nos derrama!

Que felicidade brota de tuas casas!

35 De umas apenas resta a escada cheia de corpos;

de outras o cano de gás, a torneira, uma bacia de criança.

Não há mais livros para ler nem teatros funcionando nem trabalho nas fábricas, todos morreram, estropiaram-se, os últimos defendem pedaços negros na parede, mas a vida em ti é prodigiosa e pulula como insetos ao sol,

40 ó minha louca Stalingrado!

A tamanha distância procuro, indago, cheiro destroços sangrentos, apalpo as formas desmanteladas de seu corpo, caminho solitariamente em tuas ruas onde há mãos soltas e relógios partidos, sinto-te como uma criatura humana, e que és tu, Stalingrado senão isto? Uma criatura que não quer morrer e combate, contra o céu, a água, o metal a criatura combate, contra milhões de braços e engenhos mecânicos a criatura combate, contra o frio, a fome, a noite, contra a morte a criatura combate, e vence.

As cidades podem vencer, Stalingrado!

Penso na vitória das cidades, que por enquanto é apenas uma fumaça subindo o [Volga.

Penso no colar de cidades, que se amarão e se defenderão contra tudo.

Em teu chão calcinado onde apodrecem cadáveres, a grande Cidade do amanhã erguerá a sua Ordem.”

A internacionalização do conflito parecia unir as pessoas, gerando um forte sentimento de solidariedade coletiva, de modo que o drama de cada indivíduo pudesse ser compartilhado por alguém situado num outro ponto extremo da terra. Por isso o verso "A poesia fugiu dos livros, 
agora está nos jornais" está em conformidade com os versos de "Consideração do poema", que enunciam, já no início da obra de 45 , um canto ampliado e socializante. ${ }^{54}$

Figurando a cidade como um enorme corpo desmembrado ou reduzido a cinzas, cujo magma residual do processo de destruição 'pelo fogo' tomaria a forma, no coração do eu lírico, de uma criatura resistente e voraz, o poema refere-se ao ambiente de extrema violência da batalha de Stalingrado. A esse acontecimento é colado um imaginário apocalíptico sacrificial, como se a transformação que o mundo estivesse passando justificasse as terríveis perdas humanas na batalha, “Terá custado milhares de homens, tanques e aviões, mas valeu a pena”, porque, para alcançar-se a 'nova Cidade do amanhã', se exigiria uma espécie de sacrifício.

Em sua tese de doutorado, Murilo Marcondes de Moura sublinha que "Carta a Stalingrado" seguiria um padrão arquetípico, expondo o antigo vínculo entre morte e renascimento, consubstanciado num "combate sacrificial regenerador": “(...) O mundo em guerra era algo que experimentava, como declarou o próprio Drummond, a 'transformação pelo fogo'. O poema conserva, em seu horizonte utópico e ideológico, um substrato mítico - mais precisamente apocalíptico (...)” (MARCONDES DE MOURA. 1998, p. 21). Segundo Moura, o poema traduz ainda a ideologia marxista centrada no conflito de classes, referindo-se ao tempo presente como um relato de natureza mítica atravessado por um substrato ideológico: “(...) esse sentido mítico também está informado pelo ideológico, e a promessa de uma nova era, instaurada pela vitória de Stalingrado, traduziu-se para Drummond em um internacionalismo socialista: 'o colar de cidades que se amarão e se defenderão contra tudo" (idem, p. 43).

Para aprofundar essa leitura sugerida por Murilo Marcondes, é interessante abordar, ainda que brevemente, o entrelaçamento entre as concepções de apocalipse, messianismo e utopia. O termo 'apocalipse' presume uma revelação feita por Deus aos homens, especialmente de coisas ocultas relativas ao futuro. Por isso o discurso apocalíptico também é definido muitas vezes como discurso profético, e as visões contidas nesse texto possuem sempre caráter simbólico: as partes do

\footnotetext{
54 “(...) Estes poemas são meus. É minha terra / e é ainda mais do que ela. É qualquer homem / ao meio dia em qualquer praça. (...) Ser explosivo, sem fronteiras, / por que falsa mesquinhez me rasgaria? (...)”.
} 
corpo, as coisas, as cores, os números, as personagens traduzem em símbolos as ideias sugeridas por Deus. Para compreendê-las, é preciso aprender as técnicas para a leitura dos símbolos e dos sinais divinos, caso contrário a mensagem pode ser lida de maneira equivocada.

O gênero apocalíptico difundiu-se antes da era cristã, havendo no Novo Testamento apenas um apocalipse, cujo autor cita seu próprio nome, João. Este retoma os temas proféticos contidos no Velho Testamento, como o do "Grande Dia" de Iahweh, em que Deus desce à terra para libertar o seu povo da escravidão, dando-lhes poder para destruir seus inimigos. Após o grande combate escatológico entre os exércitos do céu e as nações pagãs, é vislumbrada a "Jerusalém futura", que compreende, ao mesmo tempo, uma "Jerusalém celeste", "Vi também descer do céu, junto de Deus, a Cidade santa, uma Jerusalém nova" (Novo Testamento e Salmos, 1988, p. 510); e uma "Jerusalém messiânica", a qual já é a "Jerusalém celeste", mas tem ainda o trabalho de converter os povos pagãos ao 'Deus verdadeiro': “As nações caminharão à sua luz, / e os reis da terra trarão a ela sua glória; suas portas nunca se fecharão de dia / - pois ali já não haverá noite -" (idem, p. 511).

Daí a noção de messianismo corresponder à ideia de transformação e de redenção da humanidade por meio do entronizamento de um messias, que pode ser um indivíduo, uma classe social, uma ideologia, uma cidade, o que está intimamente relacionado à concepção de utopia, que também projeta no futuro uma nova ordem de caráter salvífico para a coletividade.

Note-se neste verso de "Carta Stalingrado", "Que quando abrirmos o jornal pela manhã teu nome (em ouro oculto) estará firme no alto da página", o caráter apocalíptico de revelação de coisas ocultas a acontecer no futuro, referindo-se inclusive, talvez, ao 'ouro' que caracterizará a "rosa aurilavrada", metáfora da obra completa, da "rosa do povo aberta...", de "Mário de Andrade desce aos infernos", bem como ao "frango de ouro" brilhando ao sol, de "Canto ao homem do povo Charlie Chaplin". O poema como um todo explicita um discurso apocalíptico messiânico, exaltando "Stalingrado" como uma espécie de 'messias' sacrificado para o surgimento da 'cidade futura', como se lê nestes versos: "Penso na vitória das cidades, que por enquanto é apenas uma fumaça 
subindo o Volga. / Penso no colar de cidades, que se amarão e se defenderão contra tudo. / Em teu chão calcinado onde apodrecem cadáveres, / a grande Cidade do amanhã erguerá a sua Ordem."

Contudo, parece haver aqui uma inversão do discurso apocalíptico bíblico, no qual a 'nova cidade' desceria dos céus para a terra, como um raio de luz vindo do alto. Não só em "Carta a Stalingrado", como também nos demais poemas de A Rosa do Povo, a imagem de nascimento de uma nova vida se dá sempre a partir do chão, do solo, da terra, e é nisso que se pode notar, talvez, a alusão de Drummond à simbologia alquímica, que, como dissemos nas considerações preliminares, tenta alcançar a regeneração da vida e das coisas da natureza, por meio de metáforas da transmutação de metais inferiores em ouro, ascendendo sempre de baixo no sentido de algo melhor. $^{55}$

Retoma-se, assim, a concepção já vista em poemas como “O mito" e "Morte do leiteiro", de que o processo simbólico de transformação da matéria, do sujeito e da realidade alude, em certas ocasiões, a operações alquímicas desagregadoras, como está dito nestes versos do poema "Retorno", de Fazendeiro do ar, citados já no primeiro capítulo da dissertação: "Sou eu nos meus vinte anos de lavoura / de sucos agressivos, que elabora / uma alquimia severa, a cada hora."

Note-se que em "Carta a Stalingrado" há a referência à utilização do fogo, "aprendem contigo o gesto do fogo', que pode se referir à operação alquímica da calcinação, consistente na metáfora de uma transformação da matéria pelo fogo, convertendo o que é sólido em cinzas, as quais, por sua vez, podem ser adicionadas a matérias já em processo de putrefação, para que deste magma vivo e amorfo renasça algo novo. Não por acaso, talvez, "Carta a Stalingrado" construa a imagem da mistura dos produtos da calcinação e da putrefação: “Em teu chão calcinado apodrecem cadáveres", no qual a Stalingrado, convertida em "criatura humana" pelo processo de personificação da cidade operado no poema, erguerá sua “Ordem”. Aliás, a respeito dessa qualidade

\footnotetext{
${ }^{55}$ Citamos poemas e seus respectivos versos em que podem ser vistas tais imagens de nascimento de vida proveniente da terra: "Uma flor nasceu na rua! (...) Uma flor ainda desbotada / ilude a polícia, rompe o asfalto." ("A flor e a náusea"); "Nos áureos tempos /que dormem no chão" ("Nos áureos tempos"); "Um inseto cava / cava sem alarme / perfurando a terra / sem achar escape // (...) em verde, sozinha, / antieuclidiana, / uma orquídea forma-se." ("Áporo"); "O campo está dormindo e forma um chinês" ("Campo, chinês e sono"); "o mundo que se esvai em sujo e sangue, I outro mundo que brota, qual nelumbo" ("Visão 1944").
} 
transformadora da guerra, vale repetir que o próprio Drummond, na apresentação de Confissões de Minas, diz que o mundo estaria “(...) submetido a um processo de transformação pelo fogo" (DRUMMOND DE ANDRADE. 2011a, p. 12).

Quanto à esperança utópica de transformação do mundo, condensada no seu último verso, é sublinhado na análise de "Carta a Stalingrado" feita por Iumna Simon, que “(...) as palavras grafadas em maiúsculas e o futuro do presente, de valor profético e anunciativo, dão ao verso um sentido de confiança na vitória do mundo socialista" (SIMON. 1978, p. 102). E para que o canto assuma essa perspectiva de esperança, o poeta parece partir do verbo "sentir" ("sinto-te com criatura humana"), para o verbo pensar ("Penso na vitória das cidades", "Penso no colar de cidades"), ou seja, para uma posição mais reflexiva conquistada ao longo do poema, retomando aí a concepção, já vista em outras composições do livro, acerca do caráter fundamental que tem a transformação da consciência para o processo de emancipação do indivíduo, modificação essa que se difundiria pela coletividade, também por meio da poesia.

Pensemos agora na relevante questão da função da arte enquanto instrumento para 'emancipação do homem comum', por meio de um processo de tomada de consciência, que, metonimicamente, refere-se também à ideia de ‘emancipação do proletariado’ proposta por Marx.

Assim, antes de prosseguirmos com a análise, é interessante diferenciarmos sucintamente as noções de uma 'emancipação política burguesa' e a de uma 'autoemancipação operária'. No primeiro caso, parte-se da ideia de que a 'sociedade civil' deve ser constituída necessariamente pelos elementos da propriedade privada e da livre concorrência, o que faz com que a sociedade seja caracterizada como um conjunto de indivíduos em constante luta uns contra os outros. Sobre os princípios capitalistas é construído o 'mito do salvador supremo', espécie de 'messias' que encarna todas as virtudes da vida pública face à corrupção dos homens; um ser superior vindo de fora, que paira acima da humanidade. Segundo Michael Löwy, "esse mito aparece na maior parte das doutrinas políticas da burguesia em desenvolvimento: para Maquiavel, ele é o 'Príncipe'; para Hobbes, o 'Soberano Absoluto'; para Voltaire, o déspota 'esclarecido'; para Rousseau, o 
'Legislador'; para Carlyle, o 'Herói”" (LÖWY. 2012, p. 44). Assim, vê-se que o 'messianismo burguês' supõe uma ajuda vinda 'do alto', na medida em que há uma cisão entre a 'sociedade civil' alienada e a vida política, cujo gestor soberano se põe numa hierarquia superior, como guardião de tudo o que é 'público'.

Quanto à 'autoemancipação do proletariado', não se esperaria mais por uma libertação que fosse trazida de fora. Ao contrário, o primeiro passo a ser dado é uma tomada de consciência dos indivíduos da sociedade, que, depois, podem optar pela ação revolucionária. Deixam de ser objetos e produtos da história, para se converterem em sujeitos ativos e produtores de transformações sociais. Nesse sentido, transcrevemos trecho do "testamento político" de Engels, citado por Löwy: "Quando se trata de uma remodelagem total da organização social, as próprias massas precisam estar presentes, precisam já ter compreendido o que está em jogo, pelo que devem empenhar o corpo e a vida" (LÖWY. 2012, p. 49).

É interessante notar como o testemunho de Engels, acerca da necessidade de uma tomada de consciência, quanto ao que se busca na luta pela liberdade, parece de certa forma dialogar com estes versos de "Pelos mortos", um dos poemas ingleses de guerra traduzido por Abgar Renault, escrito por W. J. Brown em 1941: “Preces por nós, que precisamos compreender: / só pelas coisas que ama o homem combaterá. / Seu dever foi cumprido, / e é um alto apelo para defendermos / as coisas simples pelas quais os homens morrem" (RENAULT. 1942, p. 40). Não por acaso, talvez, este último verso foi transcrito por Drummond ao final de sua apresentação à coletânea, na qual é enunciada a necessidade de que o homem venha a compreender o porquê do seu combate, evitando tornar-se "simples instrumento de economias em luta" (idem, p. 4). E aí entraria o papel do poeta, como uma espécie de 'catalisador' das reivindicações e dos desejos da coletividade, exprimindo-os de maneira esclarecedora por meio da palavra poética.

Poderíamos aqui até mesmo traçar uma certa aproximação entre a função política do artista, enquanto "guia” de 'homens comuns', segundo Drummond, e o papel dos “comunistas" (termo que englobaria os ideólogos, os dirigentes políticos e a vanguarda do operariado) concebido por Marx, 
segundo Michael Löwy: "Marx considera seu papel $e$ o dos comunistas um instrumento da autolibertação das massas, porque ele assiste ao nascimento de um movimento operário autônomo e acredita que ele é capaz de ascender à consciência de sua tarefa histórica" (LÖWY. 2012, p. 52). Nesse sentido, vale notar que no poema "Visão 1944" de A Rosa do Povo, depois de pintar um quadro terrível do presente de guerra, o eu lírico passa a visionar uma realidade futura. E reconhece que o sujeito dessa possível transformação seria o povo:

\footnotetext{
"Meus olhos são pequenos para ver

as mãos que se hão de erguer, os gritos roucos,

os rios desatados, e os poderes

ilimitados mais que todo exército.

(...)

Meus olhos são pequenos para ver

tudo que uma hora tem, quando madura,

tudo que cabe em ti, na tua palma,

ó povo! que no mundo te dispersas.

(...)

Meus olhos são pequenos para ver

o mundo que se esvai em sujo e sangue,

outro mundo que brota, qual nelumbo,

- mas veem, pasmam, baixam deslumbrados."
}

A visão utópica de um mundo emergindo do chão, "em sujo e sangue”, retoma a imagem dos últimos versos de "Carta a Stalingrado", "Em teu chão calcinado onde apodrecem cadáveres", como se ambas as imagens se referissem à mesma mistura de pó e de matéria humana em decomposição, na qual seriam gerados simultaneamente o "nelumbo" - cujo valor simbólico no oriente pode ser comparado ao da 'rosa' no ocidente - e a nova "Ordem" socialista. Esse movimento ascendente, que parte sempre da terra ou do próprio interior das massas, reflete a inversão da ideologia burguesa fundamentada na ideia de um 'salvador supremo' vindo 'do alto', a qual se aproxima, inclusive, de uma ideia de redenção divina propagada pela religião católica. 
A visão utópica materialista de Drummond acaba por depositar em cada indivíduo a responsabilidade social pela transformação da própria consciência e da sociedade, o que, porém, não exclui a relação desse mesmo sujeito, convertido em produtor dos acontecimentos históricos, com uma dimensão simbólica relacionada a linguagens ancestrais, como a do mito e a da alquimia. Seria antes a confluência entre revolução e catarse, materializada no gesto sacrificial, que ao imolar o corpo, liberta o eu de tensões reprimidas referentes a um estado de individualismo e de descontinuidade, abrindo-o ao todo ilimitado do mítico e do universal, que também pode estar informado pelo político. 


\section{A utopia da rosa}

\subsection{A rosa aurilavrada: "Anúncio da rosa"}

Apesar de pouco analisado pela fortuna crítica drummondiana, consideramos "Anúncio da rosa" um poema central na coletânea, por ser o único a tratar exclusivamente da imagem-símbolo da "rosa", explorando a um só tempo as esferas política, metapoética e simbólica, como costuma acontecer em muitos dos poemas de A Rosa do Povo. Concomitantemente à representação de aspectos da realidade objetiva, o poema alude a possíveis dimensões simbólicas ainda não demonstradas. Além disso, ele é analisado no mesmo capítulo em que abordamos os poemas finais do livro, "Mário de Andrade desce aos infernos" e "Canto ao homem do povo Charlie Chaplin", pois entendemos que há um diálogo interessante entre os três poemas, pelo fato de os dois últimos resumirem o que nossa leitura propõe como uma "utopia da rosa".

\section{“ANÚNCIO DA ROSA}

Imenso trabalho nos custa a flor.

Por menos de oito contos vendê-la? Nunca.

Primavera não há mais doce, rosa tão meiga

onde abrirá? Não, cavalheiros, sede permeáveis.

5 Uma só pétala resume auroras e pontilhismos, sugere estâncias, diz que te amam, beijai a rosa, ela é sete flores, qual mais fragrante, todas exóticas, todas históricas, todas catárticas, todas patéticas.

Vede o caule, 
Autor da rosa, não me revelo, sou eu, quem sou?

Deus me ajudara, mas ele é neutro, e mesmo duvido

que em outro mundo alguém se curve, filtre a paisagem,

pense uma rosa na pura ausência, no amplo vazio.

15

Vinde, vinde,

olhai o cálice.

Por preço tão vil mas peça, como direi, aurilavrada, não, é cruel existir em tempo assim filaucioso.

Injusto padecer exílio, pequenas cólicas cotidianas,

20

oferecer-vos alta mercancia estelar e sofrer vossa irrisão.

Rosa na roda,
rosa na máquina,
apenas rósea.

Selarei, venda murcha, meu comércio incompreendido, pois jamais virão pedir-me, eu sei, o que de melhor se compôs na noite, e não há oito contos. Já não vejo amadores de rosa.

Ó fim do parnasiano, começo da era difícil, a burguesia apodrece.

Aproveitem. A última

rosa desfolha-se."

Inicialmente, iremos dialogar com as análises que John Gledson e Fernando Braga Franco Talarico fizeram do poema acima. No caso de Gledson, diz ele que a poética de A Rosa do Povo se baseia na confiança do poeta de que os poemas são "formas vivas", a espelharem as imagens do mundo objetivo. Espécie de 'rosa concreta', que, no entanto, é ao mesmo tempo caracterizada como uma “forma instável”, precária, prestes a 'destruir-se', por referir-se a um mundo, cuja apreensão de suas estruturas objetivas (históricas, sociais, linguísticas, econômicas, etc.), se dá sempre de maneira fragmentada, estando sempre sujeita a transformações, dada sua instabilidade: 
"A rosa, portanto, é uma forma instável, e o poeta nunca pode ter certeza de sua existência por mais que nos 'garanta' que nasceu. Esta insegurança aparece numa forma deliciosamente irônica em 'Anúncio da rosa' (...), vazado numa língua de leilões, como se o poeta vendesse os seus produtos para um público possível mas desinteressado. O exagero natural da língua não esconde a precariedade da rosa ('Vede o caule / traço indeciso'), outra vez na hora da destruição ('a última rosa / desfolha-se'). De novo, afirma-se a sua relação com o mundo exterior ('Uma só rosa resume auroras e pontilhismos / sugere estâncias, diz que te amam, beijai a rosa').”(GLEDSON, 1981, p. 196-197)

Segundo Gledson, mesmo que haja no poema uma afirmação de sua relação com o mundo como a utilização da "língua de leilões" -, não deixa ele de dialogar com a poesia de Mallarmé, sendo exemplo este verso, "pense uma rosa na pura ausência, no amplo vazio", que remete a trecho do ensaio "Crise de verso", do poeta francês. ${ }^{56} \mathrm{O}$ crítico também sugere que, em muitos poemas da obra de 45, haveria uma certa influência da poética simbolista, especialmente mallarmeana: “ $a$ sua ideia de que a poesia é um arabesco que abraça as coisas sem reduzi-las lembra o ideal mallarmeano de que a poesia deve sugerir e não nomear coisas" (idem, p. 197). De todo modo, sublinha a diferença fundamental entre Drummond e Mallarmé, no sentido de que o poeta mineiro tem a "crença de que as palavras e a poesia (que habita o 'reino das palavras') refletem a estrutura da realidade" (idem, ibidem), e que, por isso, não consegue fazer uma "poesia pura", conforme idealizada pelo francês, destituída de vínculo com a matéria do cotidiano e eliminando qualquer nota de elocução autoral, como se os poemas se formassem a partir de um trânsito exclusivo das palavras. ${ }^{57}$

Fernando Braga Talarico, por sua vez, concorda com a leitura de Gledson no que diz respeito à ligação de "Anúncio da rosa" com o real objetivo. Porém, considera que este teria feito

\footnotetext{
${ }^{56}$ Eis o trecho de "Crise de verso": "Digo: uma flor! E, ainda, fora do oblívio em que minha voz relega qualquer contorno, enquanto algo de outro que os cálices conhecidos, musicalmente se levanta, ideia mesma e suave, a ausente de todos buquês." (MALLARMÉ, 2010, p. 167)

57 Segue o trecho de "Crise de verso", que trata da noção de "arte pura" mallarmaeana: "A obra pura indica a desaparição elocutória do poeta, que cede a iniciativa às palavras, pelo choque de sua desigualdade mobilizadas; elas se iluminam de reflexos recíprocos como um virtual rastro de fogos sobre pedrarias, substituindo a respiração perceptível no antigo sopro lírico ou a direção entusiasta da frase" (MALLARMÉ, 2010, p. 164).
} 
uma leitura pouco aprofundada do poema, por não ter explorado a sua dimensão de engajamento. Em sua análise, Talarico desdobra a leitura inicial de Gledson acerca do uso da língua de 'pregões públicos", demonstrando como o "anúncio" do título tem relação com uma ideia de "publicidade", de modo que o eu lírico tenta convencer o público a consumir a "rosa", cujos atributos são "sublimes":

"O preciosismo lexical, que se expressa pelo emprego da segunda pessoa do plural em referência a 'cavalheiros', bem como pelo uso de alguns vocábulos e construções sintáticas 'elevados', denuncia as necessidades simbólicas do público, já que a 'publicidade' (um dos sentidos do 'anúncio') procura ressaltar os atributos 'sublimes' da 'rosa' como forma de convencê-lo ao consumo, criando identidade entre 'público' e 'produto'." (TALARICO, 2011, p. 129)

Talarico prossegue expondo que, dentro da lógica do mercado capitalista, o artista e os produtos de seu trabalho seriam submetidos a um processo de "rebaixamento", já que a "alta mercancia estelar" seria objeto de "irrisão" por parte do público burguês, que a avaliaria por "preço tão vil". Esse menosprezo pelo trabalho poético, no entanto, acabaria por rebaixar o próprio sujeito da depreciação:

“Ao reduzir a multiplicidade de valores e de sentidos da 'rosa' à 'vileza' da mercadoria (esvaziando-a, portanto, de simbolismo), o 'respeitável público' não se encontra à 'altura' do símbolo, que tanto fez por identificar-se com quem lhe deve conferir realidade: o público. É a 'baixeza' do público ('escarninho', incapaz de reconhecer o justo valor da obra, não apenas em termos estéticos e simbólicos mas também em termos de esforço produtivo) o que cria um descompasso entre o real simbólico e o real concreto." (idem, p. 130-131) 
Talarico ressalta que a "rosa" anunciada no poema reuniria, a um só tempo, as dimensões simbólica e política, apresentando um sentido "integrativo", como se a própria "flor", alegoria do ofício poético, estivesse em constante transformação, ressignificando a relação orgânica entre os dois polos:

"Esse é o sentido especificamente político da arte drummondiana em A rosa do povo, em que a 'sociedade' integra as 'sete flores' desde a microperspectiva de 'uma só pétala', embora sem se restringir às 'cólicas cotidianas', e tampouco sem se restringir ao seu oposto (o ‘sublime simbólico' da 'alta mercancia estelar', 'aurilavrada').” (idem, p. 133)

Apesar de sublinhar enfaticamente a qualidade "integrativa" de A Rosa do Povo, abarcando os polos simbólico e político, para gerar a noção de um real mais complexo, Fernando Talarico se concentra somente no aspecto do engajamento, não explorando os elementos simbólicos contidos em "Anúncio da rosa”, nem sua relação com os elementos cotidianos, o que, aí sim, acabaria por realizar uma leitura aprofundada do poema.

Não podemos negar que, conforme a leitura de Talarico, haja uma figuração da "publicidade" com a palavra "anúncio", mesmo porque, em "Nosso tempo", poema que figura de maneira ampla o quadro de negatividade do contexto da obra de 45, há alusão explícita ao mundo publicitário, "No céu da propaganda / aves anunciam / a glória", o que mostra a presença desse assunto na poética do livro. Com efeito, a linguagem publicitária operaria no mundo uma cisão entre o significante e o significado de cada palavra, de modo que elas se tornassem "ermas de melodia e conceito" ("Procura da poesia"), só podendo ser lidas na sua esfera mais prosaica, ou seja, enquanto propaganda de mercadorias.

Mas a palavra "anúncio" possui uma forte carga simbólica, relacionando-se, por exemplo, aos evangelhos cristãos (Mateus, Marcos, Lucas e João), os quais possuem capítulos denominados 
como "anúncio da paixão" ou "anúncio da nova economia”. Não podemos esquecer que Drummond sempre evidenciou sua ligação com o texto bíblico. E, por exemplo, na crônica "Um sinal", publicada pela primeira vez em 1932, no jornal Minas Gerais, e depois reunida em Confissões de Minas, já na década de 40, há como epígrafe os versículos de 11 a 13, do capítulo 8 do Evangelho de Marcos. ${ }^{58}$ O termo "evangelho" tem o sentido de narrar a 'boa nova' que Jesus Cristo veio trazer e, na referida crônica, Drummond narra que Jesus, ao se deparar com pessoas "cegas" para enxergar qualquer "sinal" de sua divindade, preferiu adotar o "processo de ceticismo":

“A resposta de Jesus é, como sempre, desconcertante. Dessa boca, onde morava a sabedoria, as palavras saíam surpreendentes. (...) Não se calou, como poderia ser a forma da sua amargura diante dos cegos da pior espécie, e mais tarde se calaria, quando Pilatos entendeu de perguntar-lhe que coisa é a verdade. Não concordou, propiciando o sinal que atestasse aos espíritos mais escuros a evidência da sua natureza. (...) Jesus preferiu fazer, numa palavra, o processo do ceticismo. Até hoje essa palavra tem a sua oportunidade, porque as gerações continuam exigindo um sinal.” (DRUMMOND DE ANDRADE. 2011a, p. 196)

Nessa interpretação singular da mensagem cristã, Drummond levanta a dúvida se existiriam tantos "sinais" no mundo, que as pessoas, confundidas, não conseguiriam vê-los; ou se antes não haveria sinal nenhum, mas sim o que cada indivíduo carrega consigo, cabendo apenas a este, conforme sua formação e sensibilidade, interpretar as imagens do mundo. Tal ceticismo está presente nestes versos de "Anúncio da rosa", em que o sujeito põe em dúvida a sua própria autoria no processo de composição da "rosa", ao mesmo tempo em que a reafirma:

\footnotetext{
${ }^{58}$ Segue a epígrafe da crônica "Um sinal": "II. Saíram os fariseus e começaram a discutir com Ele, procurando obter d'Ele um sinal do céu, para O experimentarem. 12. E Ele, dando um profundo suspiro dentro do seu espírito, disse: Por que pede esta geração um sinal? Em verdade vos digo, que a esta geração nenhum sinal será dado. 13. E deixando-os, tornou a embarcar para o outro lado. (Marcos, 8)" (DRUMMOND DE ANDRADE, 2011a, p. 195).
} 


\begin{abstract}
“Autor da rosa, não me revelo, sou eu, quem sou?
Deus me ajudara, mas ele é neutro, e mesmo duvido

que em outro mundo alguém se curve, filtre a paisagem,

pense uma rosa na pura ausência, no amplo vazio."
\end{abstract}

A dúvida parece se relacionar à identidade precária do sujeito poético, que, como vimos, está em perene constituição, gerando-se no e pelo poema, caracterizando-se como um processo contínuo de transformação, o que poria em questão a própria noção de autoria da obra. Todavia, ao dizer que 'deus é neutro', o sujeito transfere exclusivamente ao homem a responsabilidade pela autoria do poema, duvidando inclusive da possibilidade de que, num outro mundo (transcendente, celeste?), fosse talvez imaginada uma "rosa", do mesmo modo como a que é pensada aqui, a partir de um indivíduo específico, situado neste mundo material.

De acordo com Gledson, o verso "pense uma rosa na pura ausência, no amplo vazio" remeteria intencionalmente à passagem de "Crise de verso", em que Mallarmé imagina o surgimento de uma flor abstrata e composta por palavras em feixes musicais. A nosso ver, o verso reforça o momento 'intermediário' que "Anúncio da rosa" figura em A Rosa do Povo, mesmo porque a palavra "anúncio" encerra o sentido de "sinal", que indica um evento por acontecer, a saber, a materialização e abertura da "rosa": "Primavera não há mais doce, rosa tão meiga / onde abrirá?". 59

Retomando o vínculo de "Anúncio da rosa" com o Evangelho, podemos dizer que esse acontecimento futuro - a encarnação da 'rosa aberta' -, mesmo que aludisse implicitamente à figura de Jesus, não o seria de caráter religioso, mas sim estético. Pois, nesse sentido, podemos fazer o paralelo do poema com a crônica "Canto de Natal no bonde", publicada pela primeira vez em 25 de dezembro de 1930, em O Estado de Minas, e reunida depois como o penúltimo texto de Confissões

\footnotetext{
${ }^{59}$ Para ilustrar o momento que precede à 'encarnação' da "rosa", trazemos estes versos do poema "A anunciação", de Manuel Bandeira, cuja imagem de duas "rosas" de luz simbolizam Jesus, ainda no sangue de Maria: "Como no extremo horizonte / A primeira, desmaiada, / Celagem da madrugada, / Duas rosas transluziram / Nas faces da Virgem pura: / Já era Jesus no seu sangue, / Antes de, infinito Espírito / Mudado em corpo finito, / Se fixar em forma humana / Na matriz santificada." (BANDEIRA, 1993, p. 234)
} 
de Minas, em que Drummond explicita a maneira, sempre artística, como ele pensa a figura de Jesus:

"Por isso te chamamos: Jesus, com a possível comoção na voz. Não o Jesus que já lemos, o dos evangelistas e o dos romancistas. Jesus denso, profundo e taumatúrgico. Jesus inquietante ou literário. Jesus de Renan e de Emil Ludwig. De Cecil B. de Mille. A literatura e o cinema trabalhando o perfil de um Messias, e as lentes da lenda desordenando-lhe os contornos. Mas Jesus, simplesmente Jesus, presença misteriosa, diáfana, imperceptível e pressentida. Jesus mais adivinhado que realizado. Jesus sem desenho e sem sombra. O nosso pensamento, Jesus, não alcança mais que a suspeita de um deus. E se te descobríssemos todo, seria para nós um pasmo eterno.” (DRUMMOND DE ANDRADE, 2011a, p. 218)

A 'desordenação de contornos' de um "Jesus sem desenho e sem sombra” se aproximam do que sugerem o "traço indeciso" e a 'flor mentada no vazio' de "Anúncio da rosa”. Isso demonstra que Drummond explora o sentido simbólico, e não religioso, de Jesus, porque admite ter dúvida quanto à existência de Deus, reconhecendo as suas limitações em relação a esse mistério, não tendo propriamente uma postura ateia, mas sim agnóstica. ${ }^{60}$

Note-se ainda que os versos seguintes de "Anúncio da rosa", "Vinde, vinde / olhai o cálice", remetem naturalmente ao simbolismo da "Demanda do Graal", que é a procura do cálice em que Jesus se serviu na última ceia, e no qual José de Arimatéia recolheu o sangue derramado do Cristo na cruz. Nessa taça é feito o "rito da comunhão", pelo qual as pessoas participam simbolicamente do sacrifício de Cristo. ${ }^{61}$ A 'Demanda do Graal' também trata da questão da 'cegueira' do homem

\footnotetext{
${ }^{60} \mathrm{Na}$ última entrevista de Drummond, concedida a Geneton Moraes Neto em 1987, o poeta declara o seu agnosticismo, ao ser perguntado sobre a existência de Deus: "Quem afirma que ele existe ou não existe emite uma opinião puramente pessoal, porque não há nenhuma base científica para afirmar ou negar a existência de Deus. O que se pode verificar imediatamente é que existe uma ordem natural, uma organização do universo físico. E essa organização por uns é atribuída a um espírito superior chamado Deus. Por outros é atribuída a um mistério que a natureza vai sucessivamente deslindando - mas ainda está muito longe de esclarecer de todo. Fico no meio. Considero-me agnóstico. Sou uma pessoa que não tem capacidade intelectual e competência para resolver o problema infinito que é se existe ou não existe uma divindade" (MORAES NETO. 2007, p. 57).

${ }^{61}$ Vale notar que, em 1944, ou seja, na época em que eram escritos os poemas de A Rosa do Povo, o Instituto Nacional do Livro, vinculado ao Ministério da Educação, onde Carlos Drummond trabalhava, havia recém publicado a primeira
} 
na sua busca pelo cálice, que está por perto mas não é notado, porque o indivíduo estaria mais atento ao sentido prosaico da 'demanda' do que às suas condições espirituais. ${ }^{62}$ Por isso a utilização do verbo "curvar-se", no verso "que em outro mundo alguém se curve", assim como o verso "Injusto padecer exílio, pequenas cólicas cotidianas", nos transmitem o sentido de um gesto de sacrifício do eu lírico para compor, ou 'encontrar' a "rosa”, também simbolizada pelo "cálice”, onde acontecerá a 'comunhão' com os leitores.

Em “Anúncio da rosa", há também a imagem da 'rosa aurilavrada' que "se compôs na noite". Ou seja, a imagem de uma 'flor de luz' que emergiu do 'produto da dissolução'. No seu estudo acerca da simbologia alquímica, Jung discorre sobre a correspondência entre os símbolos do “cálice", da "rosa" e da "flor de ouro". Segundo o analista, estes simbolizariam o 'lugar' de gestação do "corpo diamantino", ou seja, de um 'corpo incorruptível e imortal', que corresponde ao símbolo de Cristo: "Cristo na rosa, no colo de Maria (...); o lugar germinativo do corpo diamantino na flor de ouro" (JUNG, 2011a, p. 120). De modo semelhante à "rosa multifolhada" figurada nos cantos XXX e XXXI do "Paraíso" da Divina Comédia de Dante, o símbolo da "flor de ouro" teria, para Jung, um aspecto mandálico, e cresceria do fundo das trevas para desabrochar em luz, movimento que metaforizaria uma passagem de elementos do inconsciente para a consciência:

"A flor de ouro é a luz, e a luz do céu é o Tao. A flor de ouro é um símbolo mandálico que já tenho encontrado muitas vezes nos desenhos dos meus pacientes. Ela é desenhada a modo de um ornamento geometricamente ordenado, ou então como uma flor crescendo da planta. Esta última, na maioria dos casos, é uma formação que irrompe da obscuridade, em cores luminosas e incandescentes, desabrochando no alto sua flor de luz

versão portuguesa do texto medievo, A demanda do Santo Graal, comentada pelo padre Augusto Magne. E, a pedido de Mário de Andrade, Drummond lhe enviou um exemplar do referido livro, como se lê na correspondência entre ambos: “Carlos, esta é só pra acusar o recebimento da Demanda do Santo Graal, muitíssimo obrigado" (DRUMMOND DE ANDRADE. 2002, p. 510). Assim, é bem possível imaginar que o mineiro tivesse lido esse livro em 1944. Além disso, é interessante registrar que, em O tupi e o alaúde (1979), Gilda de Mello e Souza associa Macunaíma à Demanda do Santo Graal: "A hipótese que levanto é que Macunaíma pode filiar-se, sob certos aspectos, a uma remota tradição narrativa do Ocidente, o romance arturiano, que por sua vez desenvolve um dos arquétipos mais difundidos na literatura popular universal: o busca do objeto miraculoso, no seu caso, o Graal" (MELLO E SOUZA, 1979, p. 79).

${ }^{62}$ Segue verbete ilustrativo acerca da "Demanda do Graal": "a Demanda do Santo Graal exige condiçôes de vida interior raramente reunidas. As atividades exteriores impedem a contemplação que seria necessária e desviam o desejo. Ele está perto mas não é visto. É o drama da cegueira diante das realidades espirituais, tanto mais intensa quando mais se crê na sinceridade da busca. Na verdade, o homem está mais atento às condições materiais da 'demanda' que às suas condições espirituais”' (CHEVALIER. GHEERBRANT, 2002, p. 476-477). 
(...). Esta simbólica refere-se a uma espécie de processo alquímico de purificação e de enobrecimento; a escuridão gera a luz e a partir do 'chumbo da região da água' cresce o ouro nobre; o inconsciente torna-se consciente, mediante um processo de vida e crescimento (...). Desse modo, se processa a unificação de consciência e vida.” (JUNG. 2012, p. 39-40)

Assim, pode-se ver que a 'flor aurilavrada' de “Anúncio da rosa” guarda relação com a simbologia alquímica, metaforizando a obra e o seu processo de composição, que abarcaria "sete flores", número que simboliza uma noção de totalidade em movimento. ${ }^{63}$ Por isso, também, que "Anúncio da rosa" nos parece de grande importância para um entendimento acerca do aspecto processual e da pretensão totalizante da obra de 45 , que busca articular todos os poemas na unidade do livro.

Não por acaso, talvez, a capa da primeira edição de A Rosa do Povo, de autoria de Santa Rosa guarde certa semelhança com imagens presentes em tratados alquímicos, como a da "flor de sete pétalas" da Symbolographia de Boschius (1702), e a da marca tipográfica de Wilhelm Wessel, impressor da primeira edição do Manifesto da Fraternidade Rosa-Cruz (1615). ${ }^{64}$ Neste último caso, é interessante notar que, no frontispício da primeira edição, consta que o manifesto é dirigido a “todos os eruditos e governantes da Europa" (RIJCKENBORGH, 2004, p. XIV).

\footnotetext{
${ }^{63}$ Segue explicação sobre a simbologia do número "7": "O número 7 o símbolo universal de uma totalidade, mas de uma totalidade em movimento ou de um dinamismo total. Como tal, ele é a chave do Apocalipse (7 igrejas, 7 estrelas, 7 Espíritos de Deus, 7 selos, sete trombetas, 7 trovões, 7 cabeças, 7 calamidades, 7 taças, 7 reis...)" (CHEVALIER. GHEERBRANT, 2002, p. 827). Além disso, trazemos Ernst Bloch, que discorre sobre o sentido dos sete dias das Núpcias químicas de Christian Rosenkreuz, que representam as sete estações da confecção da pedra filosofal: "se a alquimia é entendida como dama de honra de uma transformação do mundo ou 'reforma geral'(...). Essa interpretação explica os sete dias das núpcias abertamente como as sete estações da obra alquimista, trazidas à luz do dia intelectual como: destillatio [destilação], solutio [dissolução], putrefactio [putrefação], nigredo [escurecimento], albedo [refração de luz], fermentatio [fermentação] e projectio medicinae [projeção medicial] (tintura de ouro)" (BLOCH, 2006a, p. 188-189).

${ }^{64}$ Em Ficção e confissão: ensaios sobre Graciliano Ramos, Antonio Candido ressalta a capacidade artística de Santa Rosa, que, por meio da ilustração da capa do romance Caetés, registrou de forma original o movimento e as ambiguidades do livro: "Neste espaço, dividido em dois níveis, o artista registrou o movimento do romance (...). Pela maneira de tratar o espaço e as figuras, o desenho de Santa Rosa abre portanto a possibilidade de uma leitura ambigua (...). Com isto, vemos que dentro do 'grupo de Maceió' surgiu um artista que, por meio do desenho, exprimiu um modo de ler Caetés, denotando o enredo e sugerindo a estrutura de ambiguidades" (CANDIDO. 2006b, p. 131132).
} 


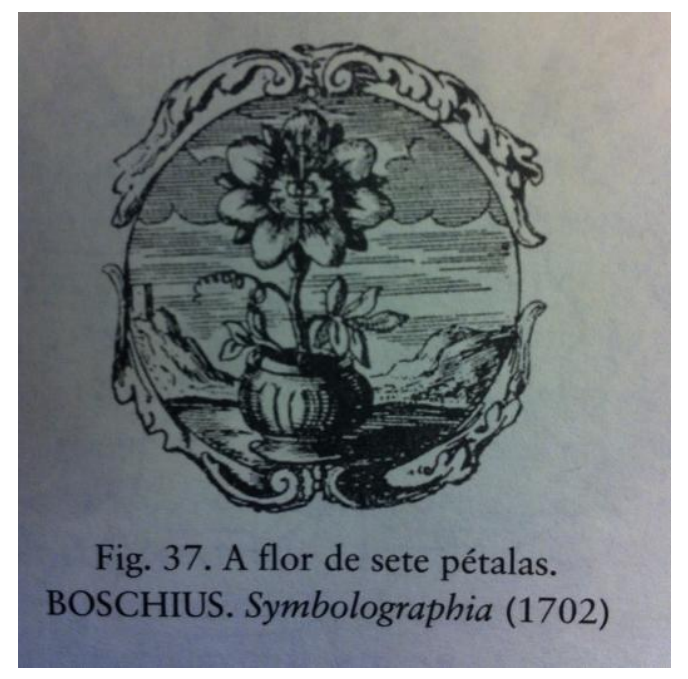

Fig. 1 - flor de sete pétalas

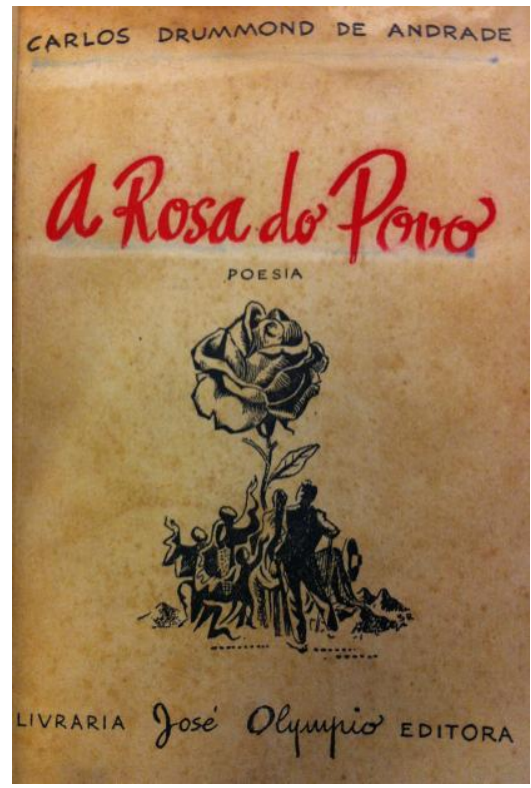

Fig. 3 - capa $1^{\text {a }}$ edição A Rosa do Povo

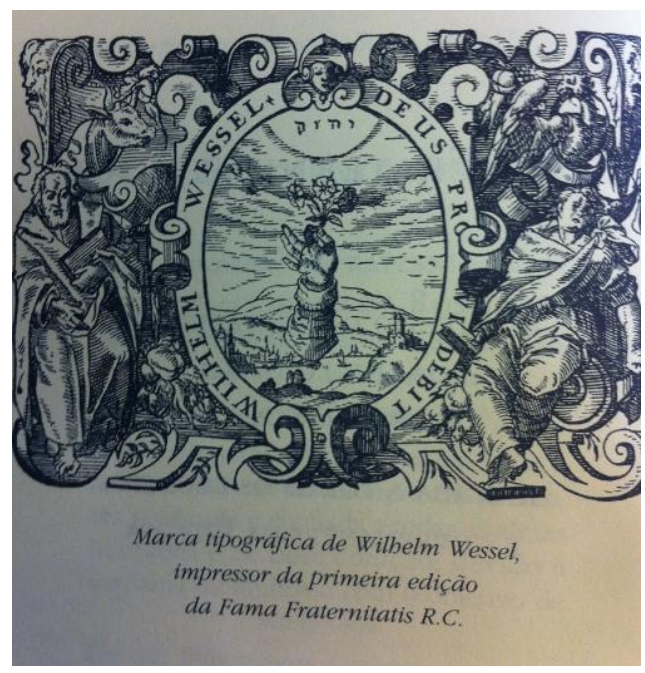

Fig. 2 - marca tipográfica

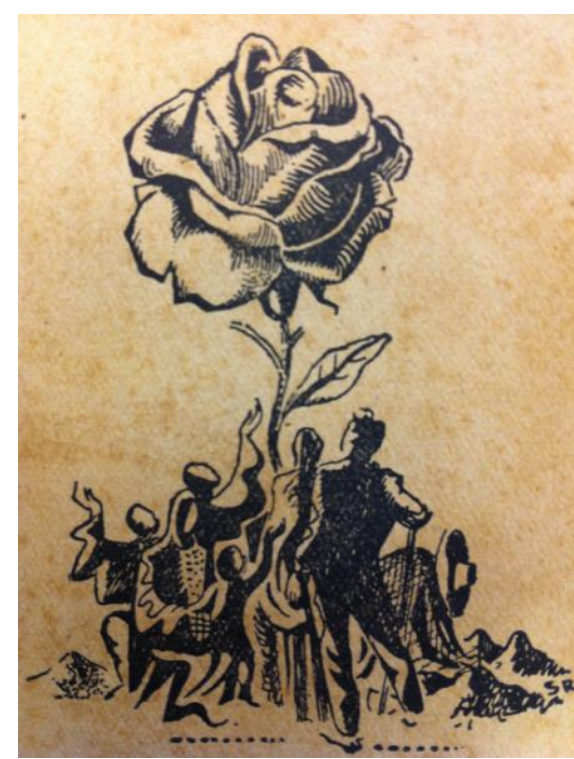

Fig. 4 - detalhe capa

No desenho de Santa Rosa, são retratadas diversas pessoas (como um homem empunhando uma enxada, uma mulher, uma criança no colo de uma mulher), todas situadas no chão, e olhando para a flor, no alto, a qual brotou do meio deles. Algumas inclusive erguem as mãos, indicando um gesto de 'reverência' ou de procura da "rosa". Vê-se, assim, que, na capa de Santa Rosa, é captada a intenção do livro de 45, subvertendo qualquer discurso elitista que ofertasse a "flor" para "eruditos" 
ou "governantes", na medida em que a "rosa", num movimento cíclico, é originada do povo e redestinada a ele.

Esse mesmo movimento circular pode ser notado na imagem dos versos "Rosa na roda, / rosa na máquina". O símbolo da "roda", além inserir a "rosa" dentro de um processo mais amplo de composição do livro, nos permite ter a ideia de concentração de todos os fragmentos da obra numa mesma unidade corpórea: "Uma só pétala resume auroras e pontilhismos", "ela é sete flores", de "Anúncio da rosa"; ou "Colo teus pedaços. Unidade / estranha é a tua", de "Canto ao homem do povo Charlie Chaplin". ${ }^{65}$

A amplitude do símbolo da "rosa" no Ocidente foi muito bem demonstrada no estudo de Iumna Simon, que, para iluminar a escolha de Drummond pelo símbolo floral como título da coletânea, não apenas citou Northrop Frye, que sublinha o aspecto "apocalíptico" da "rosa", como também trouxe o trecho final de uma crônica de Eça de Queiroz, "As Rosas” (1893), a realçar o seu conteúdo político e social. Na crônica, é descrito o movimento expansivo de apropriação do símbolo da "rosa" pelos operários da Europa, a qual se estaria convertendo, pouco a pouco, na "flor do socialismo". ${ }^{66}$ Ou seja, devido ao caráter político social atribuído à "rosa", é possível dizer que

\footnotetext{
${ }^{65}$ Em nota ao texto de Jacob Böhme, Aurora (1612), Agustín Andreu Rodrigo explica o símbolo da roda: “<... en el Padre todas las fuerzas están unas en otras como una sola fuerza...>, de lo cual es un ejemplo la rueda. Aparece aquí por vez primera la imagen de la rueda, que se repetirá luego con la imagen principal del proceso según nacen Dios, la Naturaleza y cada una de las cosas - se repetirá, sobre todo en los capítulos finales de 〈Aurora〉, justo cuando el mismo Böhme haya adquirido facilidad para ver el proceso en todo" (BÖHME, 1979, p. 409-410).

${ }^{66}$ Eis o trecho do estudo de Iumna Simon: "Segundo Northrop Frye, "no Ocidente a rosa ocupa tradicional posição de prioridade entre as flores apocalípticas: o uso da rosa como um símbolo de comunhão do Paradiso vem-nos facilmente ao espirito (...)" O significado dessa escolha pode ser ainda avaliado através de uma bela crônica de Eça de Queiroz, 'As Rosas' (1893), que se desenvolve exatamente em torno da simbologia da 'rosa' - a flor de 'carreira mais triunfal', embora não pertencente à grande aristocracia floral como a açucena ou o loto. Eis como Eça termina sua crônica: ' $E$ flor profundamente interesseira e astuta! Já no primeiro de Maio, que se vai tornando o grande festival do proletariado, eu vejo a rosa quieta e contente nas calosas mãos dos operários em folga. Nos jardinetes dos mineiros, em Inglaterra e em França, já floresce sempre, entre as saladas democráticas, um pé de roseira viçoso e prometedor. Em todos os meetings, nas greves, é usual que a rosa venha armando a casaca dos chefes, ou apareça, bordada e já com a autoridade dum emblema, nas bandeiras das associações... E estou antevendo que esta hábil e intrigante flor, que foi sucessivamente helénica, pagã, imperial, feudal, católica, mística; que, captando-lhes o amor, partilhou o poder dos heróis, dos senados, dos césares, dos barões, dos papas, dos santos; que se identificou arteiramente com Vénus, quando era Vénus que no seu cinto fechava o mundo todo, e se identificou logo com a Virgem Maria quando por seu turno foi a Virgem que pousou os pés sobre o orbe - anda a realizar sua lenta conversão, e pouco a pouco se insinua e se entrelaça no novo e tremendo poder que se levanta, e toda ela se prepara, e se avermelha, e se perfuma para ser, oficialmente e ritualmente, a flor do socialismo" (SIMON. 1978, p. 125-126).
} 
cada pétala das "sete flores" que compõem a "flor" drummondiana, também simboliza o povo, traduzindo a confiança do poeta na utopia socialista. ${ }^{67}$

Assim, o "comércio" a que o sujeito lírico se propõe, em "Anúncio da rosa”, guarda a um só tempo as dimensões simbólica, política e metalinguística. Como já dissemos, o discurso retórico que atravessa o poema consiste num gesto de valorizar, inicialmente, o ofício poético e os seus produtos de "alta mercancia estelar". Há uma interpelação ao público para que os consuma, por meio de verbos no imperativo na segunda pessoa do plural, o que atribui à fala um caráter irônico, por sua suposta 'polidez'. Mas, depois de refletir a respeito da complexidade da obra, do trabalho árduo para conceber a 'peça aurilavrada', sublinhando as suas qualidades 'históricas', 'sublimes', ‘catárticas', o eu lírico passa a demonstrar irritação com a indiferença que sente, por parte do público, em relação à "rosa":

\begin{abstract}
"Por preço tão vil mas peça, como direi, aurilavrada, não, é cruel existir em tempo assim filaucioso.

Injusto padecer exílio, pequenas cólicas cotidianas, oferecer-vos alta mercancia estelar e sofrer vossa irrisão.”
\end{abstract}

Vê-se aí uma postura de 'altivez irritada' do sujeito poético, que, diante da percepção de que seria objeto de irrisão por parte dos não "amadores de rosa", reconhece a injustiça de uma troca tão desigual. Nessa troca haveria, de um lado, o sujeito que se submete a sacrifícios, se exilando no 'longínquo' e enfrentando os dramas mais cotidianos; e, de outro lado, um público presunçoso, que

\footnotetext{
${ }^{67}$ Trazemos ainda, para gerar novas questões, a leitura de Vagner Camilo acerca da 'flor' "puramente mentada" do poema "Contemplação no banco", de Claro Enigma. Citando Gledson, que entenderia que essa 'flor imaginada' seria a mesma de A Rosa do Povo, Camilo diz que, no poema do livro de 51, haveria uma dissociação entre a utopia poética, encarnada pela "rosa", e a utopia socialista, encarnada pelo "povo": "o que parece ocorrer é a dissociação entre o sonho utópico encarnado por ela e o empenho combativo, a intervenção poética na realidade presente que ele buscava combater" (CAMILO. 2001, p. 218). Isso porque, haveria a diferenciação entre a 'flor' "escultura de ar", de "Contemplação no banco", e a "flor' que "furou o asfalto", de "A flor e a náusea”, já que a crença no ideal socialista conferiria materialidade a esta última, enquanto que a primeira permaneceria na esfera da imaginação. Segundo Camilo, a "rosa" só seria do "povo" caso se convertesse, no poema, numa imagem de aspecto "material", deixando de permanecer na esfera de um "anúncio" do que ainda viria a ser. Podemos questionar, todavia, se o simples ato de imaginar uma 'flor', na forma do poema, já não seria um gesto de atribuir-lhe materialidade?
} 
escarnece da sua poesia. Manifesta, então, desprezo pelo público, ao recusar o "comércio" com aqueles que desvalorizam o seu trabalho:

\begin{abstract}
"Selarei, venda murcha, meu comércio incompreendido, pois jamais virão pedir-me, eu sei, o que de melhor se compôs na noite, e não há oito contos. Já não vejo amadores de rosa.

Ó fim do parnasiano, começo da era difícil, a burguesia apodrece.
\end{abstract}

Aproveitem. A última rosa desfolha-se."

O verbo 'selar' também significa fechar hermeticamente um discurso. A partir disso, podemos retomar a ideia desenvolvida no primeiro capítulo, de que Drummond faria uso de uma retórica, que, simultaneamente ao gesto de revelar os mistérios que a envolvem, se fecharia aos olhos do leitor. Assim, seriam de certa forma conciliadas as instâncias paradoxais do enigma e da exigência de comunicação, evitando-se o risco de uma leitura exclusivamente prosaica dos seus poemas. Esse procedimento retórico contraditório, de oferecer e depois recusar a entrega do conteúdo da mensagem, garantiria maior eficácia persuasiva sobre o receptor, que se sentiria estimulado a buscar aquilo que lhe é negado e que ainda não compreende.

E, de fato, permanecem cifrados alguns versos do final do poema, como a segunda alusão a "oito contos", que não parece tratar somente de um valor monetário à altura do esforço do poeta, mas, também, de um número simbólico, o qual, na tradição cristã, por exemplo, remeteria ao surgimento de um 'novo mundo'. ${ }^{68}$ Já o “anúncio” do desaparecimento da 'estética parnasiana' e da 'sociedade burguesa' se dá ironicamente, por uma dicção afetada que emula o próprio estilo e

\footnotetext{
${ }^{68} \mathrm{Na}$ tradição cristã, o "oito" simbolizaria a chegada de uma "era futura", em que houvesse a ressureição não só do Cristo como de um novo homem: "Quanto ao Oitavo Dia, que sucede aos seis da criação e do sabbat, ele é o símbolo da ressurreição, da transfiguração, anúncio da era futura eterna. Comporta não só a ressurreição do Cristo mas também a do homem. Se o número 7 é, sobretudo, o do Antigo Testamento, o 8 corresponde ao Novo. Anuncia a beatitude do século futuro num outro mundo" (CHEVALIER. GHEERBRANT, 2002, p. 653).
} 
vocabulário parnasianos, e expõe de forma grotesca a decadência de uma classe: “Ó fim do parnasiano, começo da era difícil, a burguesia apodrece". Nos dois últimos versos, enfim, o tratamento por "vós" é convertido em "vocês", e, apesar de o 'chamado' se aproximar do público, demonstra ainda uma atitude paradoxal, ao conciliar uma provocação à leitura, à afirmação de que a “última rosa” já se estaria decompondo, tornando-se, assim, inacessível.

Numa leitura descontextualizada, os dois versos finais de "Anúncio da rosa” poderiam indicar um último gesto de comunicação entre o poeta e o público. De modo que, ao serem expostas os 'atributos valiosos' da 'flor aurilavrada' e o sacrifício do sujeito poético na sua confecção, bem como o menosprezo do público na recepção dela, o eu lírico, irritado com isso, se fechasse em si mesmo, à maneira dos 'românticos incompreendidos', recusando-se a ofertar novamente a 'flor'. Mas, como vimos, podemos ler esse discurso ambíguo, ornado em ironia, como uma estratégia retórica, não só para evitar uma leitura do poema restrita à sua dimensão prosaica, como também para instigar, no leitor, o desejo pela compreensão do símbolo da "rosa" na sua amplitude, inserido na totalidade do livro.

\subsection{A rosa do povo aberta: "Mário de Andrade desce aos infernos"}

Um dos motivos que acirrou o eixo de tensão poética entre individualismo e participação política na obra de Carlos Drummond foi o relacionamento intelectual e afetivo com Mário de Andrade, iniciado em 1924 por meio de correspondência escrita, depois que um grupo de turistas procedentes de São Paulo, em visita às cidades históricas de Minas Gerais, passou por Belo Horizonte. Entre eles se incluíam artistas como Blaise Cendrars, Tarsila do Amaral, Oswald de Andrade e o próprio Mário, sendo os dois últimos as principais figuras do movimento literário modernista. Na apresentação do livro A lição do amigo, Drummond reconhece que entre ele e o autor de Macunaíma, "Estabeleceu-se imediatamente um vínculo afetivo que marcaria em 
profundidade minha vida intelectual e moral, constituindo o mais constante, generoso e fecundo estímulo à atividade literária, por mim recebido em toda a existência" (DRUMMOND DE ANDRADE, 1982, p. vii).

Mário de Andrade tinha o projeto de contribuir com a formação de uma 'literatura culta da língua brasileira', sistematizando as diferenças léxicas e gramaticais existentes nos diferentes estados do Brasil, para que a 'língua brasileira' alcançasse um caráter 'nacional universalista.' Mário acreditava numa espécie de arte de ação que, segundo ele, implicaria num sacrifício do próprio eu artístico, com a finalidade de alcançar maior função humana, maior valor 'edificante e utilitário' de sua arte em favor da realização de seu projeto. Isto pode ser lido em trechos de cartas endereçadas a Drummond, transcritas pelo último na crônica "Suas cartas", de Confissões de Minas. Na referida crônica, Carlos ressalta a contraposição entre a sua postura de um certo individualismo, e a necessidade de Mário de se aproximar dos homens, comunicar-se com eles, assim como o caráter pedagógico de suas cartas:

"Essa necessidade de se sentir junto dos amigos era reflexo de outra, maior, de se sentir junto com os homens em geral (...) Os rapazes de Minas, ou pelo menos um dos rapazes com quem ele se carteava padecia do mal contrário: antipatizava com o gênero humano. A correspondência entre os dois tinha que ser assim eriçada de discordâncias. $\mathrm{O}$ indivíduo encaramujado em si mesmo lutava com o escritor socializante, antiartístico por deliberação, apesar de fundamentalmente artista, capaz de sacrificar o melhor de si mesmo para chegar a uma comunicação maior com os outros homens. E - circunstância ainda mais desconcertante - esse furor de socialização não servia nenhum pensamento político, não era partidarista, não queria salvar a humanidade. Mário de Andrade, cem por cento professor, e o melhor professor que já conheci, embora nunca lhe ouvisse uma aula, pregava simplesmente a vida, a 'gostosura' sempre encontrada no ato natural de viver, com todas as suas consequências e responsabilidades.” (DRUMMOND DE ANDRADE, 2011a, p. 73-74)

A ideia de um 'autossacrifício' do artista, para alcançar uma linguagem com maior caráter comunicativo, repercutiu fortemente na poética de A Rosa do Povo. Tal questão foi analisada por 
Iumna Maria Simon, para quem Drummond assumiu o risco de aproximar o poético da prosa, ganhando assim em informação semântica e comunicatividade. A estudiosa reconhece também a tensão entre a linguagem participativa e um outro movimento, ainda vinculado ao contexto, mas em termos negativos, o qual recusa a referência aos eventos exteriores, fechando-se num discurso autorreferente, a sublinhar a condensação da linguagem poética:

“É nosso propósito demonstrar, então, que no livro de 1945 explodem, porque se encontram e se negam, as grandes tensões da poesia de Drummond. Se aflora em primeiro plano o problema da comunicação poética, é porque o fator novo do 'engajamento' exige, como sua contraparte necessária, um novo tipo de prática artística. Contudo, ao mesmo tempo que se impõe a necessidade de comunicação pela arte, única arma de que o artista dispõe para a luta, propõe-se, e de maneira esplêndida, a poética da negação do assunto, da negação da poesia temática e celebrativa, seja da subjetividade, seja dos acontecimentos exteriores." (SIMON, 1978, p. 58)

Podemos ver, assim, que a dicção sempre tensa da obra de 45 , oscilante entre um discurso mais aberto à comunicação e outro de aspecto mais cifrado, já vinha sendo elaborada há muito tempo, na medida em que o diálogo entre os dois poetas se pautou, muitas vezes, em torno da questão da função social da poesia. Exemplo dessa discussão está na carta enviada por Mário a

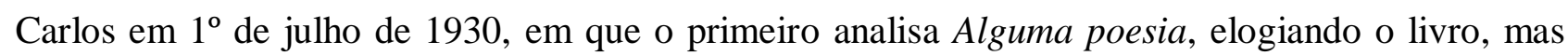
também o criticando, ao dizer que o individualismo tanto de Drummond quanto de Bandeira reduziria o 'pragmatismo social' de suas obras, por situá-los numa espécie de 'beco sem saída':

"Vou direto às restrições. Uma não é restrição, propriamente: é o desencontro de nossas personalidades: o meu lado socialista, o meu lado pragmático que irrita tanta gente e acabou fazendo o Ribeiro Couto romper comigo. Seu livro é excessivamente individualista. Há uma exasperação egocêntrica enorme nele. Está claro que isso não diminui em nada os valores do seu lirismo. Diminuem a meu ver os valores edificantes utilitários de sua poesia. Você e o Manuel Bandeira se equiparam inteiramente nisso. A sociedade, a humanidade, a nacionalidade funcionam pra vocês em relação a vocês e não vocês em relação a elas. Não é 
um defeito permanente, como se vê. É uma questão de época que me faz censurar o excessivo individualismo de Alguma poesia e de Libertinagem. Acho que vocês podem dar um passo a mais e cair nalgum sobrerrealismo que acho que já está além do individualismo". (DRUMMOND DE ANDRADE. 2002, p. 386-387)

Seguindo o contexto de politização da intelligentsia em curso na década de $1930,{ }^{69}$ Mário revela não apenas sua inclinação ideológica pelo socialismo, como também explicita as premissas "utilitárias" que permeiam a construção de sua obra, contrapondo-as ao movimento, presente em Alguma poesia, de apropriação dos elementos do mundo de fora para dentro, ou seja, como se o mundo existisse sempre em função da subjetividade do eu lírico. Isto se assemelharia, em certa medida, ao movimento centrípeto mencionado na análise acima de "Consideração do poema" (“ $O$ bonde, a rua, / o uniforme de colégio se transformam, são ondas de carinho te envolvendo"), na medida em que este já se encontra inserido na poética do livro de 1945, consciente dos movimentos simultâneos de interiorização e de engajamento do discurso. A carta de Mário de Andrade revela, também, uma estratégia retórica para influenciar o interlocutor mineiro, persuadindo-o a compartilhar de suas premissas estético-políticas, o que pode ser visto ao longo de toda a correspondência havida entre ambos. Às críticas de Mário, Drummond admite, em carta de $1^{\circ}$ de janeiro de 1931, sua imaturidade para evadir-se da postura individualista e para tratar de outros temas morais ou políticos em sua poesia:

"Eu confesso que não consigo evadir-me de meu individualismo para vogar nessas paragens largas e povoadas para as quais me solicitam as tendências intelectuais do meu tempo (...) E confesso mais, não sem tristeza, que a minha opinião individualista é tanto mais lamentável quanto me força eternamente aos mesmos exercícios poéticos, à eterna repetição de temas morais que constituem o tecido inalterável de minha vida, e que por fim devem aporrinhar o leitor, que diabo! Tanto mais que me aporrinham a mim próprio como você sabe perfeitamente." (DRUMMOND DE ANDRADE. 2002, p. 401-402)

\footnotetext{
${ }^{69}$ A respeito do contexto político-ideológico da década de 30, já mencionamos, na primeira nota da introdução, trecho do ensaio de Antonio Candido, "A Revolução de 30 e a cultura".
} 
O aprendizado da "lição do amigo" parece ter alcançado o seu ápice no penúltimo poema de A Rosa do Povo, "Mário de Andrade desce aos infernos", escrito em homenagem a Mário, morto em 25 de fevereiro de 1945, em que o eu lírico, por meio de uma compreensão da obra de Mário, pôde enfim dizer “a rosa do povo aberta...”, ou seja, a rosa que se constitui na articulação dos eixos poéticos do livro. Não por acaso, porém, no antepenúltimo poema da coletânea, "Os últimos dias", o eu lírico se refere expressamente a "Carlos Drummond de Andrade", empregando o nome inteiro do sujeito empírico pela primeira vez na obra poética drummondiana:

"E a matéria se veja acabar: adeus, composição
que um dia se chamou Carlos Drummond de Andrade.
Adeus, minha presença, meu olhar e minhas veias grossas,
meus sulcos no travesseiro, minha sombra no muro,
sinal meu no rosto, olhos míopes, objetos de uso pessoal, ideia de justiça,
[revolta e sono, adeus, vida aos outros legada."

Esta 'morte sacrificial', além de remeter ao exemplo do 'sacrifício' de Mário, reforça a percepção de que, no processo de composição da obra, o sujeito poético drummondiano sofreu uma tamanha transformação, que acabou por se refletir na própria noção que o sujeito empírico tinha de si. Como foi dito no primeiro capítulo, Henri Meschonnic define como utópica essa relação entre o homem e o poema, de modo que uma forma de vida possa ser transformada por uma forma de linguagem e, reciprocamente, que uma forma de linguagem possa ser modificada por uma forma de vida. Esta operação só pode ser realizada por um sujeito específico, a saber, o "sujeito do poema" (MESCHONNIC, 2009, p. 211).

É interessante pensar por que essa 'morte' simbólica ocorre justamente no final do poema que antecede "Mário de Andrade desce aos infernos". Não será uma indicação do sacrifício do eu 
drummondiano para resgatar Mário dos “infernos”? E não haverá nesse gesto uma reflexão acerca da finitude e do alcance da poesia, a exigir sempre que um leitor futuro a faça renascer por meio de uma leitura renovada? Também não se estará questionando a eficácia comunicativa e política da poesia no presente, só cabendo ao poeta o ato de fazer o poema e legá-lo a quem quer que seja? Vejamos:

\section{"MARIO DE ANDRADE DESCE AOS INFERNOS}

I

Daqui a vinte anos farei teu poema

e te cantarei com tal suspiro

que as flores pasmarão, e as abelhas,

confundidas, esvairão seu mel.

$5 \quad$ Daqui a vinte anos: poderei

tanto esperar o preço da poesia?

É preciso tirar da boca urgente

o canto rápido, ziguezagueante, rouco,

feito da impureza do minuto

10 e de vozes em febre, que golpeiam

esta viola desatinada

no chão, no chão.

II

No chão me deito à maneira dos desesperados.

Estou escuro, estou rigorosamente noturno, estou vazio,

15 esqueço que sou um poeta, que não estou sozinho,

preciso aceitar e compor, minhas medidas partiram-se,

mas preciso, preciso, preciso.

Rastejando, entre cacos, me aproximo. 
Não quero, mas preciso tocar pele de homem,

20 avaliar o frio, ver a cor, ver o silêncio,

conhecer um novo amigo e nele me derramar.

Porque é outro amigo. A explosiva descoberta

ainda me atordoa. Estou cego e vejo. Arranco os olhos e vejo.

Furo as paredes e vejo. Através do mar sanguíneo vejo.

25 Minucioso, implacável, sereno, pulverizado,

é outro amigo. São outros dentes. Outro sorriso.

Outra palavra, que goteja.

III

O meu amigo era tão

de tal modo extraordinário,

30 cabia numa só carta,

esperava-me na esquina,

e já um poste depois

ia descendo o Amazonas,

tinha coletes de música,

35 entre cantares de amigo

pairava na renda fina

dos Sete Saltos,

na serrania mineira,

no mangue, no seringal,

40 nos mais diversos brasis,

e para além dos brasis,

nas regiões inventadas,

países a que aspiramos,

fantásticos,

45 mas certos, inelutáveis,

terra de João invencível,

a rosa do povo aberta...

IV

A rosa do povo despetala-se,

ou ainda conserva o pudor da alva? 
50 É um anúncio, um chamado, uma esperança embora frágil, pranto infantil no

Talvez apenas um ai de seresta, quem sabe.

Mas há um ouvido mais fino que escuta, um peito de artista que incha,

e uma rosa se abre, um segredo comunica-se, o poeta anunciou,

o poeta, nas trevas, anunciou.

55 Mais perto, e uma lâmpada. Mais perto, e quadros,

quadros. Portinari aqui esteve, deixou

sua garra. Aqui Cézanne e Picasso,

os primitivos, os cantadores, a gente de pé-no-chão,

a voz que vem do Nordeste, os fetiches, as religiões,

60 os bichos... Aqui tudo se acumulou,

esta é a Rua Lopes Chaves, 546,

outrora 108. Para aqui muitas vezes voou

meu pensamento. Daqui vinha a palavra

esperada na dúvida e no cacto.

Aqui nunca pisei. Mas como o chão

65 sabe a forma dos pés e é liso e beija!

Todas as brisas da saudade balançam a casa,

empurram a casa,

navio de São Paulo no céu nacional

70 vai colhendo amigos de Minas e Rio Grande do Sul,

gente de Pernambuco e Pará, todos os apertos de mão,

todas as confidencias a casa recolhe,

embala, pastoreia.

Os que entram e os que saem se cruzam na imensidão dos corredores,

75 paz nas escadas,

calma nos vidros,

e ela viaja como um lento pássaro, uma notícia postal, uma nuvem pejada.

Casas ancoradas saúdam-na fraternas:

Vai, amiga!

80 Não te vás, amiga...

(Um homem se dá no Brasil mas conserva-se intato,

preso a uma casa e dócil a seus companheiros

esparsos.)

Súbito a barba deixou de crescer. Telegramas 
retinem. Silêncio

em Lopes Chaves.

Agora percebo que estamos amputados e frios.

Não tenho voz de queixa pessoal, não sou

90 um homem destroçado vagueando na praia.

Muitos procuram São Paulo no ar e se concentram, aura secreta na respiração da cidade.

É um retrato, somente um retrato, algo nos jornais, na lembrança,

o dia estragado como uma fruta, um véu baixando, um ríctus o desejo de não conversar. É sobretudo uma pausa oca e além de todo vinagre.

Mas tua sombra robusta desprende-se e avança.

100 Desce o rio, penetra os túneis seculares onde o amigo marcou seus traços funerários, desliza na água salobra, e ficam tuas palavras (superamos a morte, e a palma triunfa) tuas palavras carbúnculo e carinhosos diamantes."

O poema é escrito sob o impacto do luto, com imagens e verbos que expressam um profundo sentimento de dor. $\mathrm{O}$ eu lírico teme ser levado a um estado de imobilidade, em que se isolaria para depurar, durante anos, um canto sublime em louvor do amigo. Mas recusa essa inclinação pelo monumental e por um ideal de musa poética, dirigindo-se ao "chão", a indicar um contato com a realidade presente, e repetindo o verbo "preciso", que o impele à ação e a retomar a prática poética participante, que aprendeu com Mário, de sempre buscar 'novos amigos', ou seja, a "explosiva descoberta", que o faria inclusive enxergar na escuridão, pelo afeto.

Como já dissemos, a abertura à alteridade seria a grande transformação do eu drummondiano decorrente da relação do poeta com Mário de Andrade. Ainda que esse eu não tenha 
promovido um seu total 'desaparecimento' - convertendo-o num 'sujeito lírico despersonalizado', como, para alguns autores, é o caso da poesia de Baudelaire -, se teria convertido num "sujeito poético utópico", na medida em que mantém, nos poemas, a forte marca da sua 'individualidade', ao mesmo tempo que a projeta na 'rua', aberta às vozes e aos problemas do coletivo.

Mas, justamente na seção III do poema, em que os verbos estão todos no passado, são unidas pela primeira vez, num verso, as duas palavras que dão nome ao livro, a "rosa" e o "povo". No movimento de relembrar a figura de Mário, sob o ritmo predominante da redondilha maior, o sujeito se depara com a "a rosa do povo aberta...". Sem dúvida há aí o reconhecimento e a admiração do "projeto artístico e humano de Mário de Andrade: a pesquisa cerrada da cultura popular, a penetração concreta na vida, na arte e na linguagem do povo brasileiro", como observou Iumna Simon (SIMON, 1978, p. 111). Mas restaria ainda o impasse: como mantê-la viva e aberta no presente com a morte do amigo: "A rosa do povo despetala-se / ou ainda conserva o pudor da alva?".

Essa pergunta nos parece ambígua: seria um sinal de desconfiança do poeta em relação ao seu projeto poético participativo, bem como de modéstia no reconhecimento de que artistas como Mário e Chaplin poderiam "realizar melhor aquilo que tenta fazer", como o disse Gledson? ${ }^{70} \mathrm{Ou}$ não seria antes um artifício retórico para mitigar a afirmação altiva do sujeito poético, de que somente ele poderia ter interpretado a mensagem de Mário, transformando-a na "rosa do povo"?

\footnotetext{
"Mas há um ouvido mais fino que escuta, um peito de artista que incha, e uma rosa se abre, um segredo comunica-se, o poeta anunciou, o poeta, nas trevas, anunciou."
}

\footnotetext{
${ }^{70}$ GLEDSON. 1981, p. 199.

${ }^{71}$ Para questionar uma postura de modéstia de Drummond em relação a Mário de Andrade, vale transcrever trecho da carta de Mário, de 15 de outubro de 1944, na qual ele presta 'reverência' a Drummond, chegando a dizer que o poeta mineiro é o único que consegue a sua "submissão completa": "O que eu gosto mais, o que está perto de mim, como se fosse carne minha, é você, é o que eu mais vivo. (...) você eu vivo demais, e só você (...) consegue a minha submissão completa" (DRUMMOND DE ANDRADE, 2002, p. 533).
} 
Quem senão o eu lírico drummondiano seria o portador da "chave" que abriu o "segredo" do poeta morto, captando o "anúncio da rosa"? A esse respeito, é ilustrativa a crônica "Segredos", publicada em Correio da Manhã em junho de 1947, e reunida em Passeios na ilha, em 1952. Nela Drummond fala sobre sua relação com os amigos mortos, os quais permaneceriam como 'fantasmas', incorporando-se na existência de quem os relembra: "De tantos encontros, confidências, planos, cartas, incompreensões passageiras, ficou um indestrutível fantasma, que é a verdadeira essência do amigo (...). E à força de se identificar conosco, transforma-se afinal em nós mesmos, passando a viver de efetiva existência" (DRUMMOND DE ANDRADE, 2011b, p. 25).

E este 'eu saudoso', ao converter-se no poema, faria com que o "navio que leva esta mensagem", de "Consideração do poema", alçasse voo sobre o "céu nacional", figurando, assim, a poética utópica da obra de 45, que tem também, como uma de suas inspirações, a obra andradiana. O 'navio-casa' é a imagem de um texto poético que se comunica afetivamente com as gentes de todo o Brasil, recolhendo seus cantos, confidências, histórias, e dando-lhes em troca amizade, estímulo de ação, esperança, poesia. Assim, a morte do amigo acaba sendo apenas "uma pausa oca" num dia, que não abala o projeto poético participante de A Rosa do Povo:

"Mas tua sombra robusta desprende-se e avança.

Desce o rio, penetra os túneis seculares onde o amigo marcou seus traços funerários, desliza na água salobra, e ficam tuas palavras (superamos a morte, e a palma triunfa) tuas palavras carbúnculo e carinhosos diamantes." 
O luto se destina "aos infernos", mas as palavras de Mário, ao se transformarem em poema, ou numa "casa" ("Todas as brisas da saudade balançam a casa"), ${ }^{72}$ permanecem vivas. Ou seja, é como se um lado 'escuro' do corpo fosse embora, e restasse somente a sua parte de luz. Aliás, podese ver nesse movimento de 'separação' da luz da treva, bem como na ideia de perpetuação da vida, nova referência à simbologia alquímica. Com efeito, uma das finalidades do trabalho espagírico consiste em alcançar uma "vitória total sobre a morte, vitória que tornaria o homem capaz de viver anos, séculos inteiros" (HUTIN, 1999, p. 88). E um sinal do sucesso da obra seria justamente a obtenção da cor vermelha do carbúnculo: "enfim, a cor vermelha - a do carbúnculo, a do rubi marcaria o triunfo do adepto, sua gloriosa obtenção da pedra em vermelho, a única que permite efetuar a transmutação dos metais vis em ouro" (idem, p. 43). Segundo Ernst Bloch, muitos autores célebres sempre compararam, ao longo da história, a "pedra filosofal" a certos elementos minerais, especialmente ao carbúnculo, ao rubi, ao cristal e ao diamante. ${ }^{73}$

Para Bloch, a "utopia alquimista" remete à ideia de que a natureza não traz nada, à luz do dia, que já esteja em estado de perfeição. E o trabalho do adepto seria aperfeiçoar os elementos naturais, elevando-os ao 'estado do ouro', que metaforizaria, inclusive, o ideal utópico do

\footnotetext{
${ }^{72} \mathrm{Em}$ "Consideração do poema", também há a comparação do poema à imagem da "casa": "e cresces como fogo, como casa".

${ }^{73}$ Segue o trecho em que Bloch discorre sobre a "pedra filosofal”: "A pedra filosofal é um corpo que, composto artisticamente do mais refinado mercúrio animado e de seu ouro vivo, bem como ligado por meio de um demorado fogo de forma tal que jamais poderá ser outra vez separado, é capaz de, nessa configuração, produzir, purificar e tingir os demais metais, para que sejam alçados à natureza do mais puro ouro.' Existem pelo menos descrições dessa pedra fabulosa feitas por pessoas muito célebres. As descrições são relativamente coincidentes, como se a posterior estivesse apoiada sobre os ombros da anterior. Raimundus Lullus compara a pedra com o carbúnculo. Paracelso, na Signatura rerum naturalium [Características das coisas naturais], afirma que a pedra seria pesada, de cor vermelha viva como um rubi, transparente como um cristal" (BLOCH, 2006a, p. 196). Essa mesma comparação entre a "pedra de toque" e o "carbúnculo" também é feita em $O$ Chamado da Fraternidade da Rosacruz, que, depois de falar do surgimento da "aurora", fala da chegada de um "dia bem-aventurado": "Isso será o legítimo rubi real, o carbúnculo precioso e luminoso, que, diz-se, possui e envia uma luz irradiante na escuridão, que constitui uma panaceia perfeita para todos os corpos, que pode transmutar os metais vis no ouro mais puro e afastar os homens de todas as enfermidades, de todas as angústias e todas as aflições" (RIJCKENBORGH, 2004, p. XIX). Quanto a esta última obra, é possível que Drummond já a tivesse lido antes mesmo da publicação de A Rosa do Povo, uma vez que, no poema "Canções de alinhavo", de $O$ corpo, no qual são explicitados muitas influências e possíveis rumos de sua vida e carreira literária, ele conta que sua amiga Lúcia Branco tentou iniciá-lo na filosofia Rosa-Cruz: "Lúcia Branco, o piano, tentou iniciar-me na Rosa-Cruz". Aliás, na coletânea de entrevistas Tempo, vida, poesia, o poeta mineiro conta que conheceu Lúcia Branco por conta da inicial objeção dela ao poema "No meio do caminho". Na entrevista, Drummond também ressalta as qualidades intelectuais e artísticas da amiga: "o que mais me tocou nessa longa história de um poema que não chega a ser poema foi o que eu ouvi de uma amiga, e amiga que se tornou tal precisamente por causa dele. Posso dar o nome dessa pessoa, que já não vive: Lúcia Branco. Pianista notável, depois formadora de pianistas como Artur Moreira Lima, Lúcia era culta e sensível. (...) Ganhei uma amiga de qualidade excepcional" (DRUMMOND DE ANDRADE. 1987, p. 56).
} 
nascimento de um 'corpo diamantino'. Tudo isso se caracterizaria como uma espécie de “mitologia da libertação", pela qual seria alcançada uma transformação radical do indivíduo, mediante o seu trabalho sobre os objetos: "algo, portanto, como uma catarse dos objetos, concomitante com a das almas" (BLOCH, 2006b, p. 199).

Assim, podemos ler em "Mário de Andrade desce aos infernos" uma síntese do trabalho de absorção e interpretação que o poeta realizou do projeto artístico de Mário, ou seja, do 'resgate' e 'dignificação' das 'palavras' do amigo, que estariam contidas, principalmente, na extensa correspondência havida entre ambos. ${ }^{74}$ Ofício de manipulação da matéria das palavras que, quando comparado ao trabalho alquímico sobre os objetos, realça também a transformação simbólica operada no eu lírico drummondiano, o qual, através do poema, agora mais longo e com mais variações de ritmos e formas, passa a se projetar na rua, dando voz às aspirações da coletividade, constituindo-se, assim, um sujeito poético utópico, de grande amplitude social-política.

\subsection{Renovação das palavras: "Canto ao homem do povo Charlie Chaplin"}

Além da intenção de superar a questão do alheamento face aos acontecimentos exteriores, existe na obra de 45 a ideia de transpor o impasse entre o "local" e o "universal". "É tudo meu. Ser explosivo, sem fronteiras, / por que falsa mesquinhez me rasgaria?", como se lê em "Consideração do poema". A amplitude da poética do livro abarca relações simultâneas, dentre as quais podemos sublinhar: o poeta e as palavras; o poeta e outros artistas daqui e do exterior; o poeta e os diferentes povos do mundo; a experiência pessoal e a história. O último poema de A Rosa do Povo, "Canto ao homem do povo Charlie Chaplin", não apenas resume a intenção de Drummond em superar esse impasse entre 'fronteiras territoriais', como também condensa a própria poética utópica do livro:

\footnotetext{
${ }^{74}$ Vale notar que, na entrevista de Drummond a Maria Lucia do Pazo Ferreira, o poeta diz que a poesia de Mário não exerceu influência sobre ele: "A poesia do Mário nunca me influenciou. A de Bandeira, sim. Essas foram as grandes influências literárias da minha vida e influências humanas" (PAZO FERREIRA, 1992, p. 332).
} 


\section{“CANTO AO HOMEM DO POVO CHARLIE CHAPLIN}

Era preciso que um poeta brasileiro, não dos maiores, porém dos mais expostos à galhofa, girando um pouco em tua atmosfera ou nela aspirando a viver como na poética e essencial atmosfera dos sonhos lúcidos, era preciso que esse pequeno cantor teimoso, de ritmos elementares, vindo da cidadezinha do interior onde nem sempre se usa gravatas mas todos são extremamente polidos e a opressão é detestada, se bem que o heroísmo se banhe em ironia,

era preciso que um antigo rapaz de vinte anos, preso à tua pantomima por filamentos de ternura e riso dispersos no tempo, viesse recompô-los e, homem maduro, te visitasse para dizer-te algumas coisas, sobcolor de poema.

Para dizer-te como os brasileiros te amam e que nisso, como em tudo mais, nossa gente se parece com qualquer gente do mundo - inclusive os pequenos judeus de bengalinha e chapéu-coco, sapatos compridos, olhos melancólicos,

vagabundos que o mundo repeliu, mas zombam e vivem nos filmes, nas ruas tortas com tabuletas: Fábrica, Barbeiro, Polícia, e vencem a fome, iludem a brutalidade, prolongam o amor como um segredo dito no ouvido de um homem do povo caído na rua.

Bem sei que o discurso, acalanto burguês, não te envaidece, e costumas dormir enquanto os veementes inauguram estátua, e entre tantas palavras que como carros percorrem as ruas, só as mais humildes, de xingamento ou beijo, te penetram.

25 Não é a saudação dos devotos nem dos partidários que te ofereço, eles não existem, mas a de homens comuns, numa cidade comum, nem faço muita questão da matéria de meu canto ora em torno de ti 
como um ramo de flores absurdas mandado por via postal ao inventor dos jardins.

Falam por mim os que estavam sujos de tristeza e feroz desgosto de tudo,

30 que entraram no cinema com a aflição de ratos fugindo da vida, são duras horas de anestesia, ouçamos um pouco de música, visitemos no escuro as imagens - e te descobriram e salvaram-se.

Falam por mim os abandonados da justiça, os simples de coração, os párias, os falidos, os mutilados, os deficientes, os recalcados, os oprimidos, os solitários, os indecisos, os líricos, os cismarentos, os irresponsáveis, os pueris, os caridosos, os loucos e os patéticos.

E falam as flores que tanto amas quando pisadas, falam os tocos de vela, que comes na extrema penúria, falam a mesa, os botões, os instrumentos do ofício e as mil coisas aparentemente fechadas,

40 cada troço, cada objeto do sótão, quanto mais obscuros mais falam.

II

A noite banha tua roupa.

Mal a disfarças no colete mosqueado, no gelado peitilho de baile, de um impossível baile sem orquídeas.

45 És condenado ao negro. Tuas calças confundem-se com a treva. Teus sapatos inchados, no escuro do beco, são cogumelos noturnos. A quase cartola, sol negro, cobre tudo isto, sem raios.

50 Assim, noturno cidadão de uma república enlutada, surges a nossos olhos pessimistas, que te inspecionam e meditam: Eis o tenebroso, o viúvo, o inconsolado, o corvo, o nunca-mais, o chegado muito tarde a um mundo muito velho.

E a lua pousa em teu rosto. Branco, de morte caiado, que sepulcros evoca mas que hastes 
submarinas e álgidas e espelhos

60 e lírios que o tirano decepou, e faces

amortalhadas em farinha. O bigode

negro cresce em ti como um aviso

e logo se interrompe. É negro, curto,

espesso. O rosto branco, de lunar matéria,

65 face cortada em lençol, risco na parede,

caderno de infância, apenas imagem

entretanto os olhos são profundos e a boca vem de longe,

sozinha, experiente, calada vem a boca

sorrir, aurora, para todos.

70 E já não sentimos a noite,

e a morte nos evita, e diminuímos

como se ao contato de tua bengala mágica voltássemos

ao país secreto onde dormem meninos.

Já não é o escritório de mil fichas,

75 nem a garagem, a universidade, o alarme,

é realmente a rua abolida, lojas repletas,

e vamos contigo arrebentar vidraças,

e vamos jogar o guarda no chão,

e na pessoa humana vamos redescobrir

80 aquele lugar — cuidado! - que atrai os pontapés: sentenças

de uma justiça não oficial.

III

Cheio de sugestões alimentícias, matas a fome

dos que não foram chamados à ceia celeste

ou industrial. Há ossos, há pudins

85 de gelatina e cereja e chocolate e nuvens

nas dobras de teu casaco. Estão guardados

para uma criança ou um cão. Pois bem conheces

a importância da comida, o gosto da carne,

o cheiro da sopa, a maciez amarela da batata,

90 e sabes a arte sutil de transformar em macarrão

o humilde cordão de teus sapatos.

Mais uma vez jantaste: a vida é boa. 
Cabe um cigarro: e o tiras

da lata de sardinhas.

95 Não há muitos jantares no mundo, já sabias,

e os mais belos frangos

são protegidos em pratos chineses por vidros espessos.

Há sempre o vidro, e não se quebra,

há o aço, o amianto, a lei,

100 há milícias inteiras protegendo o frango,

e há uma fome que vem do Canadá, um vento,

uma voz glacial, um sopro de inverno, uma folha

baila indecisa e pousa em teu ombro: mensagem pálida

que mal decifras. Entre o frango e a fome,

105 o cristal infrangível. Entre a mão e a fome,

os valos da lei, as léguas. Então te transformas

tu mesmo no grande frango assado que flutua

sobre todas as fomes, no ar; frango de ouro

e chama, comida geral

110 para o dia geral, que tarda.

IV

O próprio ano novo tarda. E com ele as amadas.

No festim solitário teus dons se aguçam.

És espiritual e dançarino e fluido,

mas ninguém virá aqui saber como amas

115 com fervor de diamante e delicadeza de alva, como, por tua mão, a cabana se faz lua.

Mundo de neve e sal, de gramofones roucos

urrando longe o gozo de que não participas.

Mundo fechado, que aprisiona as amadas

120 e todo desejo, na noite, de comunicação.

Teu palácio se esvai, lambe-te o sono,

ninguém te quis, todos possuem,

tudo buscaste dar, não te tomaram.

Então caminhas no gelo e rondas o grito

125 Mas não tens gula de festa, nem orgulho 
nem ferida nem raiva nem malícia.

És o próprio ano-bom, que te deténs. A casa passa

correndo, os copos voam,

os corpos saltam rápido, as amadas

130 te procuram na noite... e não te vêem,

tu pequeno, tu simples, tu qualquer.

Ser tão sozinho em meio a tantos ombros,

andar aos mil num corpo só, franzino,

135 e ter braços enormes sobre as casas,

ter um pé em Guerrero e outro no Texas,

falar assim a chinês, a maranhense,

a russo, a negro: ser um só, de todos,

sem palavra, sem filtro,

140 sem opala:

há uma cidade em ti, que não sabemos.

V

Uma cega te ama. Os olhos abrem-se.

Não, não te ama. Um rico, em álcool,

é teu amigo e lúcido repele

145 tua riqueza. A confusão é nossa, que esquecemos

o que há de água, de sopro e de inocência

no fundo de cada um de nós, terrestres. Mas, ó mitos

que cultuamos, falsos: flores pardas,

anjos desleais, cofres redondos, arquejos

150 poéticos acadêmicos; convenções

do branco, azul e roxo; maquinismos,

telegramas em série, e fábricas e fábricas

e fábricas de lâmpadas, proibições, auroras.

Ficaste apenas um operário

155 comandado pela voz colérica do megafone.

És parafuso, gesto, esgar.

Recolho teus pedaços: ainda vibram,

lagarto mutilado.

Colo teus pedaços. Unidade 
E nós, que a cada passo nos cobrimos

e nos despimos e nos mascaramos,

mal retemos em ti o mesmo homem,

$$
\begin{aligned}
& \text { aprendiz } \\
& \text { bombeiro } \\
& \text { caixeiro } \\
& \text { doceiro } \\
& \text { emigrante } \\
& \text { forçado }
\end{aligned}
$$

170

maquinista

noivo

patinador

soldado

músico

175

peregrino

artista de circo

marquês

marinheiro

carregador de piano

180 apenas sempre entretanto tu mesmo,

o que não está de acordo e é meigo,

o incapaz de propriedade, o pé

errante, a estrada

fugindo, o amigo

185 que desejaríamos reter

na chuva, no espelho, na memória

e todavia perdemos.

VI

Já não penso em ti. Penso no oficio

a que te entregas. Estranho relojoeiro,

190 cheiras a peça desmontada: as molas unem-se,

o tempo anda. És vidraceiro.

Varres a rua. Não importa

que o desejo de partir te roa; e a esquina

faça de ti outro homem; e a lógica 
te afaste de seus frios privilégios.

Há o trabalho em ti, mas caprichoso,

mas benigno,

e dele surgem artes não burguesas,

produtos de ar e lágrimas, indumentos

que nos dão asa ou pétalas, e trens

e navios sem aço, onde os amigos

fazendo roda viajam pelo tempo,

livros se animam, quadros se conversam,

e tudo libertado se resolve

numa efusão de amor sem paga, e riso, e sol.

O oficio, é o oficio

que assim te põe no meio de nós todos,

vagabundo entre dois horários; mão sabida

no bater, no cortar, no fiar, no rebocar,

210 o pé insiste em levar-te pelo mundo,

a mão pega a ferramenta: é uma navalha,

e ao compasso de Brahms fazes a barba

neste salão desmemoriado no centro do mundo oprimido

onde ao fim de tanto silêncio e oco te recobramos.

215 Foi bom que te calasses.

Meditavas na sombra das chaves,

das correntes, das roupas riscadas, das cercas de arame,

juntavas palavras duras, pedras, cimento, bombas, invectivas,

anotavas com lápis secreto a morte de mil, a boca sangrenta

220 de mil, os braços cruzados de mil.

E nada dizias. E um bolo, um engulho

formando-se. E as palavras subindo.

Ó palavras desmoralizadas, entretanto salvas, ditas de novo.

Poder da voz humana inventando novos vocábulos e dando sopro aos exaustos.

225 Dignidade da boca, aberta em ira justa e amor profundo,

crispação do ser humano, árvore irritada, contra a miséria e a fúria dos ditadores,

ó Carlito, meu e nosso amigo, teus sapatos e teu bigode caminham numa estrada de

[pó e esperança." 
O poema começa com o enaltecimento do cinema de Charles Chaplin, que marcou Carlos Drummond desde a juventude, quando vivia em Belo Horizonte nos anos 20. Carlos identificava-se com a personagem chapliniana, Carlitos, cujas características de melancolia e comicidade remetiam à figura do gauche que aquele havia definido a si próprio. A reforçar essa identificação, vale notar que um dos apelidos de infância de Drummond era Carlito. Numa de suas crônicas do jornal Minas Gerais, na década de 30, o poeta falou pela primeira vez desse personagem, definindo-o como um sujeito triste que se transforma moralmente pela esperança. ${ }^{75}$

No estudo de Gledson, há uma aprofundada análise da relação entre o poema acima e os filmes de Chaplin, dentre os quais três teriam maior importância, a saber, A Corrida do Ouro, Tempos Modernos e $O$ Grande Ditador. O crítico desenvolve sua leitura de cada seção do poema fazendo um paralelo com um determinado filme. Consideramos bastante interessante essa forma de analisar o texto, porque o situa em sua relação com o contexto artístico internacional, em que Chaplin possuía enorme popularidade, fazendo uma arte 'nova', cujo poder de comunicação era incomparável, na época, com qualquer outra forma artística. De todo modo, nossos comentários se dirigirão especialmente a questões relacionadas à superação do impasse entre o "local" e o “universal”, à constituição de um sujeito poético e de um canto utópicos.

O eu lírico se declara ironicamente um artista menor, só se igualando a Chaplin na sua faceta cômica, enquanto objeto de riso do público. E se põe numa posição de humildade ao dizer que só estaria transmitindo ao 'grande artista', "sobcolor de poema", o sentimento de admiração amorosa que os brasileiros sentem por ele. Apesar de se mostrar como uma espécie de 'hino' ao “inventor dos jardins", aludindo ao conteúdo de seus filmes, é interessante pensar no aspecto alegórico do poema, o qual encerra a um tempo as camadas política e metalinguística. O sentido do emprego do

\footnotetext{
${ }^{75}$ A referida crônica é citada na biografia de Drummond feita por José Maria Cançado: "Parece certo que, já naquele momento, Drummond via Carlitos como a personagem cuja trajetória mais valia acompanhar no século. Ele escreveu na sua crônica: 'Enfim sou dos que acham Carlitos triste, um pouco por natureza e um pouco pelos acréscimos sucessivos que críticos e artistas fizeram à sua personalidade. (...) O 'crescimento moral' de Carlitos faz-me pensar nesse ser estranho que é o artista, criador de mundos e criatura ele próprio, tão sujeito às leis do mundo exterior, ao seu sistema de influências e pressões, como os seres que a sua imaginação tirou do nada e pôs no papel, no palco e num pedaço de tela" (CANÇADO, 1993, p. 146).
} 
pronome pessoal na segunda pessoa do singular, ao longo do poema, é ambivalente. Dirige-se tanto a Chaplin, enquanto louvação de sua obra; quanto ao poema e ao sujeito poético, que se confundem. ${ }^{76}$ É como se "Canto ao homem do povo Charlie Chaplin" tentasse refletir, em filigrana, cada uma das 'temáticas' do conjunto da obra de 45, discutindo inclusive a trajetória de constituição do sujeito lírico através dos poemas.

Vemos, por exemplo, a temática do noturno, com o resgate de imagens como a do 'corvo', "Eis o tenebroso, o viúvo, o inconsolado, / o corvo, o nunca mais, o chegado muito tarde / a um mundo muito velho", retomando aí a metáfora da dissolução "do chumbo da atmosfera constritora" ("Retorno"), metal vulgar que remete ao mundo velho de 'Saturno'. Ou seja, a metáfora da dissolução de um mundo com estruturas e valores solidificados, como analisamos no poema “Anoitecer". Vemos também a temática da rememoração da infância, "E já não sentimos a noite, $e$ a morte nos evita, e diminuímos / como se ao contato de tua bengala mágica voltássemos / ao país secreto onde dormem meninos", resgate da idade de ouro que corresponde a uma infância simbólica, como é lido em "Nos áureos tempos" e "Desfile". Outra temática, ainda, é a da dificuldade na comunicação da poesia, "Mundo fechado, que aprisiona as amadas / e todo desejo, na noite, de comunicação. / Teu palácio se esvai, lambe-te o sono, / ninguém te quis, todos possuem, / tudo buscaste dar, não te tomaram", versos que remetem a "Anúncio da rosa" e a "O elefante".

Poderíamos prolongar a exposição das relações entre versos de "Canto ao homem do povo Charlie Chaplin" e outros poemas do livro, mas o que nos interessa, agora, é demonstrar a pretensão totalizante do poema, que busca condensar a fragmentação temática da obra, numa espécie de "unidade” precária: "Recolho teus pedaços: ainda vibram, lagarto mutilado. // Colo teus pedaços. Unidade estranha é a tua, em mundo assim pulverizado". Desde "Consideração do poema", o sujeito poético vem assumindo um canto cada vez mais amplo, no e pelo qual se constitui. E, como

\footnotetext{
${ }^{76}$ Segundo Chantal Castelli, aliás, "Charles Chaplin, encarnado no seu personagem Carlitos, é uma espécie de alterego do poeta" (CASTELLI, 2010, p. 15)
} 
dissemos, esse movimento de expansão, resumido nos dois poemas finais de A Rosa do Povo, busca também superar o impasse entre o 'nacional' e o 'universal'.

Na crônica "Morte de Federico García Lorca", publicada pela primeira vez no Boletim de Ariel, em 1937, e reunida em Confissões de Minas na década de 40, diz o poeta mineiro que García Lorca foi quem lhe ensinou como superar esse conflito, efetuando, nos seus poemas, uma renovação da tradição lírica espanhola e, simultaneamente, incorporando elementos de diferentes poéticas internacionais. Drummond define o espanhol como um artista que, servindo-se de sua experiência pessoal, e atuando como 'catalisador' "da efusão lírica do povo", produziu uma obra poética capaz de refletir os anseios da coletividade, possuidora de um forte caráter político revolucionário e com influência em escala internacional:

"Sua experiência poética, rica de ensinamentos fecundos, mostra a possibilidade de coexistência de um grande poeta nacional com uma força poética universal. Assim, pôde renovar a tradição gitana dos romances e canções, em versos que têm o colorido forte de Granada, os cheiros e palpitações sensuais daquela terra amorosa, e, ao mesmo tempo, integrar-se na corrente supranacional daqueles que, em diferentes países do mundo, conseguiram depurar a poesia de tudo quanto é acidental, insubstancial ou meramente decorativo. A solução harmoniosa desse pseudo mas comprometedor conflito entre o local e o universal é, para mim, a primeira lição de García Lorca. (Entre nós, haverá quem a aproveite). (...) Uma voz assim, de um poeta assim (sua influência nos países americanos de cerne espanhol é imensa; poetas amadurecidos ou gastos renovam-se ao seu contato" (DRUMMOND DE ANDRADE, 2011a, p. 98)

A atuação de Mário sempre se concentrou mais na esfera nacional e, talvez por isso, em "Mário de Andrade desce aos infernos", o 'navio-poema' voe no céu brasileiro, colhendo "as vozes" daqui. Já em "Canto ao homem do povo Charlie Chaplin", o sujeito lírico demonstra a vontade de integrar o seu canto, já repleto de referências a canções populares brasileiras como, por exemplo, "de viola ou banjo" (“América"), "na corrente supranacional" da poesia, na medida em 
que tanto os poetas nacionais quanto os internacionais são considerados por ele como seus "irmãos": "Furto a Vinicius / sua mais límpida elegia. Bebo em Murilo. / Que Neruda me dê sua gravata / chamejante. Me perco em Apollinaire. Adeus, Maiakovski. / São todos meus irmãos" (“Consideração do poema”). É como se a composição de um canto endereçado a Chaplin, artista de envergadura planetária, levando consigo as vozes populares do Brasil aliadas às experiências pessoais do poeta, resumissem a intenção internacionalista decorrente do 'aprendizado' de Drummond com Lorca, para a superação desse conflito entre "fronteiras" e para a conquista de uma experiência profunda da alteridade. Imagem comovente da esperança utópica de um futuro triunfo do canto sobre esse impasse pode ser lido no poema "Cidade prevista". 77

Outra leitura que Drummond faz da obra de Lorca é a de que a poesia do espanhol teria um ‘poder mágico' de “rejuvenescer” as palavras dos poetas que fossem ‘tocados’ por ela. O corolário dessa interpretação está presente em "Canto ao homem do povo Charlie Chaplin”, na medida em que o sujeito poético atribui ao seu canto a qualidade de um 'catalisador poético' das vozes dos seres mais frágeis, dos excluídos, dos trabalhadores mais humildes, das coisas mais simples: “Falam por mim os abandonados de justiça, os simples de coração / (...) E falam as flores que tanto amas quando pisadas / falam os tocos de vela". O sintagma "falam por mim", todavia, demonstra que o eu não se dilui ou dissolve-se, mantendo um certo 'controle' pela nomeação dos seres e coisas que falam por ele; mantém a sua individualidade, dando voz aos outros. "Um homem se dá no Brasil mas conserva-se intato" ("Mário de Andrade desce aos infernos"). De qualquer forma, a voz lírica drummondiana não se caracteriza mais como o ‘canto’ de um único sujeito, mas sim como um concerto de múltiplas vozes, apresentando aí o seu caráter utópico.

\footnotetext{
77 "Cidade Prevista": "Guardei-me para a epopeia / que jamais escreverei. / Poetas de Minas Gerais / e bardos do Alto Araguaia, / vagos cantores tupis, / recolhei meu pobre acervo, / alongai meu sentimento. / O que eu escrevi não conta. / O que desejei é tudo. / Retomai minhas palavras, / meus bens, minha inquietação, / fazei o canto ardoroso, / cheio de antigo mistério / mas límpido e resplendente. / Cantai esse verso puro, / que se ouvirá no Amazonas, / na choça do sertanejo / e no subúrbio carioca, / no mato, na vila X, / no colégio, na oficina, / território de homens livres / que será nosso país / e será pátria de todos. / Irmãos, cantai esse mundo / que não verei, mas virá / um dia, dentro em mil anos, / talvez mais... não tenho pressa. / Um mundo enfim ordenado, / uma pátria sem fronteiras, / sem leis e regulamentos, / uma terra sem bandeiras, / sem igrejas nem quartéis, / sem dor, sem febre, sem ouro, / um jeito só de viver, / mas nesse jeito a variedade, / a multiplicidade toda / que há dentro de cada um. / Uma cidade sem portas, / de casas sem armadilha, / um país de riso e glória / como nunca houve nenhum. / Este país não é meu / nem vosso ainda, poetas. / Mas ele será um dia / o país de todo homem."
} 
Ademais, ao interpretar a mensagem de Chaplin, dos seres e das coisas, o eu poético transfigura as suas palavras, redizendo-as, rejuvenescidas: “E as palavras subindo. / Ó palavras desmoralizadas, entretanto salvas, ditas de novo. / Poder da voz humana inventando novos vocábulos e dando sopro aos exaustos". E nesse gesto há a valorização do ofício artístico em geral, “O ofício, é o ofício / que assim te põe em meio de nós todos...”, em razão da ambiguidade do "tu", que se refere tanto a Chaplin, quanto ao poema e ao sujeito poético. ${ }^{78}$

De acordo com os tratados de alquimia, no entanto, só o adepto e a sua obra, que já tenham passado concomitantemente por operações como as de dissolução, putrefação, conjunção, separação, etc., conseguiriam efetuar o 'rejuvenescimento' das matérias que lhes são submetidas ao contato. Exemplo desse "trabalho alquímico", efetuado pelo sujeito e pela obra 'maduros', em substâncias materiais, pode ser lido na citação de Ernst Bloch a um antigo lema das "Odes de Salomão":

"Unicamente o puro, transformado pela própria conversão, possui o poder ressuscitador de dissolver matérias que, como o chumbo, afundaram no caos, de renová-las e despertá-las. Por meio da água santa, do Logos spermaticos [Verbo gerador], desenvolvelhes a existência e as eleva purificadas, até que todas as coisas inferiores estejam metamorfoseadas em sublimes" (BLOCH, 2006a, p. 198)

As palavras de Mário de Andrade, convertidas, no poema, pelo sujeito poético já em sua “idade madura", ganharam a força simbólica de "carbúnculo e carinhosos diamantes", cujo significado alquímico, como já explicamos, remete a um corpo que, ao tocar nos metais vulgares, os renova, elevando-os à natureza do ouro. Em "Canto ao homem do povo Charlie Chaplin", por sua vez, o canto endereçado a Chaplin pretende metaforicamente integrar-se na "corrente

\footnotetext{
${ }^{78}$ Gledson interpreta de maneira interessante a palavra "ofício" no poema, a qual teria o sentido de "persona", isto é, de 'máscara' com que a pessoa se apresenta em público: "Esse papel, no sentido de persona, é o que significa a palavra 'oficio'; (...) essa persona é de propriedade pública, e que transcende a vontade do homem Chaplin" (GLEDSON. 1981, p. 204).
} 
supranacional" da poesia, superando o impasse entre o "local" e o "universal". Dimensão universal essa que está presente no livro, sobretudo, nos poemas de guerra (e em outros também). Além disso, há no poema outra imagem simbólica da completude da obra, a saber, o "frango de ouro", que realiza a promessa da 'rosa aurilavrada mentada', de "Anúncio da rosa", do "teu nome (em ouro / oculto)", de "Carta a Stalingrado", bem como da "aurora", de "Morte do leiteiro", mostrando-se em ouro num dia pleno de sol.

Segundo Gledson, a imagem do "frango de ouro" evoca a cena final do filme Tempos Modernos, em que um "frango assado" fica preso num lustre, pairando sobre o restaurante, e Drummond a teria interpretado, efetuando a identificação entre Chaplin e o frango, e associando este último à ideia da divisão de classes, além de deixar subentendido um sentido simbólico, sobre o qual o crítico não se detém, deixando perguntas em aberto:

"Drummond lança mão desta lembrança e interpreta-a, identificando Chaplin e o assado, já este último é associado no poema à divisão entre ricos e pobres. A imagem é um exemplo da relação de Chaplin com o 'sistema', com o 'nosso tempo'. 'Mata a fome dos que não foram chamados à ceia celeste ou industrial', pela sua arte, pelas imagens e símbolos, pelo riso e pela sátira. A essência do símbolo é perfeitamente perceptível sem o conhecimento dos filmes, em parte pelas suas conotações intrínsecas (paródia do Espírito Santo ou da pomba da paz, talvez?) em parte porque integra o argumento total e construído do poema." (GLEDSON, 1981, p. 200)

Na simbologia alquímica, o frango simboliza as três fases da obra, a saber: as patas negras, a fase negra da dissolução, putrefação e calcinação; as penas brancas, a fase de depuração; e a crista vermelha, a fase de fixação da tintura de ouro. ${ }^{79}$ Além disso, a imagem do "frango de ouro",

\footnotetext{
79 "Para os alquimistas, o frango simboliza as três fases de evolução da obra, em função da sua crista vermelha, suas penas brancas, suas patas negras. É a matéria da obra que começa a ser tornar negra devido à putrefação; depois, branca, à medida que o orvalho filosófico ou ozoth a purifica; enfim, vermelha, quando está perfeitamente fixada (...) $O$ vaso dos filósofos é chamado de habitação do frango (...). O vaso dos filósofos é o princípio e a raiz de todo
} 
flutuando no ar, remete ao símbolo da "esfera de ouro alada", que também representa o "produto final" da obra alquimista, o qual, no caso específico do poema, corresponderia à "sublimação" alcançada pela expressão artística ${ }^{80}$ Assim, a alusão ao caráter utópico da alquimia, que, conforme Bloch, corresponde a "uma espécie de mitologia da libertação (...) dos objetos, concomitante com a das almas" (BLOCH, 2006a, p.199), pode ser visto nestes versos de "Canto ao homem do povo Charlie Chaplin":

\author{
"Há o trabalho em ti, mas caprichoso, \\ mas benigno, \\ e dele surgem artes não burguesas, \\ produtos de ar e lágrimas, indumentos \\ que nos dão asa ou pétalas, e trens \\ e navios sem aço, onde os amigos \\ fazendo roda viajam pelo tempo, \\ livros se animam, quadros se conversam, \\ e tudo libertado se resolve \\ numa efusão de amor sem paga, e riso, e sol.”
}

O ofício poético opera o intercâmbio entre o sujeito e as palavras, de modo que o trabalho sobre elas - como a depuração da melodia de cada vocábulo, a reflexão acerca de seus significados, a modelagem de uma forma que as recolha no espaço da página, despertando-as, assim, do 'rio difícil do sono' -, esteja também impregnado pela experiência individual do poeta, que deixa sempre os seus 'resíduos' no poema. ${ }^{81}$ Desta maneira, os produtos desse trabalho, ao ganharem

ensinamento, é a água e o receptáculo de todas as tinturas; essas palavras devendo ser entendidas no sentido da linguagem hermética: o conjunto dos conhecimentos ocultos" (CHEVALIER. GHEERBRANT, 2002, p. 451).

${ }^{80}$ Segue o comentário de Jung a uma ilustração contida na obra Aurum hermeticum (1675), em que a "esfera alada", pairando no ar, está refletida na "fonte da vida", situada na terra: "A esfera alada (chamada 'Aurum aurae') como produto final do 'opus' alquimico, espelhando-se na Fonte da vida. Representação simbólica do 'opus' com seus atributos (árvores, montanhas dos planetas etc.) (JUNG, 2011a, p. 473). Além disso, para melhor compreender a multiplicidade do processo alquímico, é interessante ler a comparação feita por Fernando Pessoa entre a noção de "gênio" e a alquimia, no texto intitulado "Goethe", de 1932: "O gênio é uma alquimia. O processo alquímico é quádruplo: 1) putrefação; 2) albação; 3) rubificação; 4) sublimação. Deixam-se, primeiro, apodrecer as sensações; depois de mortas embranquecem-se com a memória; em seguida rubificam-se com a imaginação; finalmente se sublimam pela expressão" (PESSOA. 1998, p. 269).

81 "Se de tudo fica um pouco, / mas por que não ficaria / um pouco de mim? no trem / que leva ao norte, / no barco, / nos anúncios de jornal, / um pouco de mim em Londres, / um pouco de mim algures? / na consoante? / no poço?" 
“asas ou pétalas", ou se tornarem um 'navio-casa a voar no céu nacional', acabam por conferir, simbolicamente, estas mesmas qualidades ao próprio sujeito poético, na medida em que ele se constitui no e pelo poema, conforme discorremos ao final da analise de "Procura da poesia", no primeiro capítulo. Ademais, o ofício, seguindo os princípios socializantes da poética do livro de 45 , produz o canto amplo e comunicativo, em que o sujeito se põe em relação com os leitores, transformando a sua atividade solitária da escrita em partilha amorosa, como se lê em "América", 82

O sujeito poético drummondiano, transformado no "frango de ouro" "que flutua sobre todas as fomes, no ar (...) e chama, comida geral / para o dia geral, que tarda", alcança enfim a amplitude do canto almejada já em "Consideração do poema". Passa a servir como 'alimento de renovação' a todos que sejam tocados por sua poesia, condensando em si (no poema) a mensagem de esperança que perpassa a A Rosa do Povo, as novas formas que brotam do chão e que projetam o futuro "país de todo homem” (“Cidade prevista”); esperança essa que, por seu caráter utópico, não abandona o olhar crítico sobre o passado e o presente de ruínas - o pó da destruição do mundo velho pelo fogo -, nem sobre a instabilidade do próprio sujeito poético e da linguagem, ambos em permanente devir.

("Resíduo"). Nesse sentido, é interessante trazer a comparação efetuada por Chantal Castelli, entre a poesia de Drummond e de Ponge: "Drummond, ao contrário de Ponge, não aspira à pureza da linguagem (do Nome, na terminologia de Benjamin), a dizer as coisas de modo transparente. É da dificuldade implicada no uso da linguagem humana, 'decaida', que se alimenta o poema" (CASTELLI, 2010, p. 169-170).

82 "Portanto, é possível distribuir minha solidão, torná-la meio de conhecimento. / Portanto, solidão é palavra de amor" ("América"). 


\section{Conclusão}

Buscamos evidenciar neste estudo o caráter poético e processual do livro, o que é ilustrado de maneira exemplar no verso "Colo teus pedaços. Unidade", do poema final "Canto ao homem do povo Charlie Chaplin". E utilizamos o conceito complexo da utopia como instrumento da leitura, porque ele nos permite verificar, em cada um dos poemas analisados, uma mensagem utópica específica: seja a enunciação de um canto, de um poema e de um sujeito poético de amplitude social-política; seja a projeção de um futuro idealizado, ressaltando a sua qualidade esperançosa; seja a recusa radical do canto ampliado e da realidade objetiva, sublinhando o viés crítico negativo da utopia. Os poemas se articulam ainda num todo, que se desvela lentamente na leitura da obra, cujo símbolo, a reunir o uno e o múltiplo, é a rosa.

Pensamos os dois últimos poemas, "Mário de Andrade desce aos infernos" e "Canto ao homem do povo Charlie Chaplin”, como a condensação da mensagem de A Rosa do Povo, semelhante à maneira como "Consideração do poema" e "Procura da poesia" enunciam os princípios dessa mesma poética. O sujeito lírico se projeta para o espaço público da "rua", e os poemas se tornam longos para dar espaço às diferentes vozes da coletividade, adquirindo a amplitude de um “canto", já que o contexto terrível - com campos de concentração, ditaduras, revoluções proletárias latentes - conteria coisas muito mais graves e importantes para o poeta pensar, do que uma voz centralizada num 'eu' revolvido em si, com sua "careta de gozo ou de dor no escuro", conforme se lê em "Procura da poesia". ${ }^{83}$ Os interesses do sujeito, quando voltados especialmente a questões sócio-políticas, não se limitam a fronteiras, dividindo-se entre as instâncias "local" e "universal", e poemas como "Morte do leiteiro" e "Carta a Stalingrado" demonstram essa coexistência no livro.

\footnotetext{
${ }^{83}$ Note-se o possível paralelo entre este verso de "Procura da poesia", "Não faças versos sobre acontecimentos", com estes de Lorca, "No hagas caso de lamentos / ni de falsas emociones;/ las mejores devociones / son los grandes pensamientos", citados na crônica "Morte de Federico García Lorca", de Confissões de Minas, em que Drummond afirma a necessidade de uma poesia que, em dados momentos, em vez de falar sobre instâncias inefáveis, seja veículo de um protesto "ardente e viril" (DRUMMOND DE ANDRADE, 2011a, p. 101).
} 
Outros poemas iriam de encontro ao impulso afirmativo do "canto" socializante, nos quais o sujeito se afasta da vida cotidiana, pondo-se numa situação de autoexílio. Isso pode ser verificado em "Vida menor", que transmite a mensagem de resignação diante do "grande mundo" tumultuado, buscando refúgio num universo miniaturizado; e em "Campo, chinês e sono", lido por grande parcela da crítica como estetizante e cifrado. Lemos também, todavia, tais composições inseridas no processo de confecção da obra, em que esta e o sujeito são submetidos a uma 'depuração', a qual simboliza um movimento de redução ao elemento mínimo, essencial, onde o eu possa entrar em contato íntimo com os materiais trabalhados - como as "múltiplas palavras em feixe subindo", de "Fragilidade" -, ou seja, com a 'semente' de onde brotará a "rosa". A partir daí, a imaginação passa a concentrar-se no ouro da "rosa aurilavrada" (“Anúncio da rosa”), que simboliza simultaneamente o novo canto, o novo sujeito e a projeção de um novo mundo utópicos.

Em “O mito", no entanto, quando a utopia é transferida para o território do desejo, a fantasia esboçada ao final do poema, de um "mundo sem classes e imposto (...) de contradições extintas" entre o eu e seus impulsos sexuais, não deixa de expor, de maneira mordaz, um entendimento acerca do utópico enquanto sonho de impossível materialização. O sujeito não vê solução para o impasse do desejo, posto que este se vincula ao corpo, cujo pulso é "de inquebrantável rigor" ("As contradições do corpo"), sendo, portanto, incontrolável. Assim, a projeção fantasiosa, que contivesse um lugar em que os desejos não fossem tão tumultuosos, implica num movimento forçado de sublimação da matéria, que é o corpo, retratando, neste poema específico, a consciência acerca dos limites sempre tensos entre os sonhos utópicos projetados e a realidade nua e crua.

Ao nos aprofundarmos no estudo do caráter processual de A Rosa do Povo, pudemos perceber que muitos poemas do livro remetem, direta ou indiretamente, a símbolos e a procedimentos da linguagem ancestral da alquimia - o que, até agora, não havia sido apontado pela fortuna crítica drummondiana. A partir daí, pudemos reavaliar o porquê de Drummond ter cursado a Faculdade de Farmácia em Belo Horizonte, na década de 20, onde estudou, durante dois anos, a química dos elementos na história natural, na bromatologia, na mineralogia, no laboratório. A 
alquimia, como sabemos, deu origem à química moderna, e Drummond já se interessava por assuntos relacionados à farmacologia desde muito cedo, como se pode ler na sua entrevista concedida a Maria Lucia do Pazo Ferreira, na qual o poeta diz que uma de suas grandes influências literárias foi a manipulação de farmácias antigas, às quais ele teve acesso quando criança, e que vinham com almanaques explicativos publicados pelos laboratórios.

Como dissemos, o processo alquímico consiste numa série de trabalhos que o iniciado realiza sobre a matéria, buscando transformar, simbolicamente, um metal vulgar, como o chumbo, em ouro, que é considerado o metal mais elevado e puro. Na medida em que a matéria vai sendo trabalhada pelo alquimista, até se converter em ouro, ou seja, em matéria luminosa, o próprio operador também vai passando por uma transformação no interior do seu ser, tornando-se, ao final do processo alquímico, um ser mais aprimorado.

Daí o motivo de termos acrescentado na leitura de A Rosa do Povo a noção de uma "utopia alquimista" - da qual tivemos conhecimento, pela primeira vez, por meio da leitura da obra do filósofo alemão Ernst Bloch, um dos mais renomados teóricos do conceito da utopia -, por entendermos que o processo de elaboração da "rosa aurilavrada" se apropria, metaforicamente, de muitos procedimentos da alquimia tradicional, que visam sempre à confecção de uma "Grande Obra", cujo toque venha a transformar os outros objetos em ouro. Ou seja, simultaneamente à construção da obra poética, o próprio sujeito poético vai se constituindo e se inventando no corpo de cada poema, deixando para trás uma atitude de certo individualismo descompromissado, e passando a representar, ao final, um concerto de múltiplas vozes da coletividade. O processo íntimo da alquimia, na obra, se mostraria então por esta contínua e tensionada pendulação de opostos, em que se busca integrar eu e mundo, no poema, onde convivem sentimentos ambivalentes: o desejo de se reintegrar numa realidade transpessoal; e a paralisação pelo temor da perda da própria identidade poética. Trata-se de um movimento incessante de materialização e de desconstrução do canto, a sublinhar a concepção drummondiana acerca da precariedade do poético. 
Podemos dizer enfim que, para enfrentar a complexa poesia de Carlos Drummond de Andrade, a qual efetua a conjunção sempre tensa entre as noções de "razão" e de "mistério", nos foi de enorme utilidade o estudo aprofundado do conceito da utopia, o qual não apenas abrange a crítica materialista aos fenômenos sociais, históricos, econômicos e estéticos, como também se fundamenta na abordagem de fenômenos de natureza mais subjetiva, como a psicanálise, assim como de natureza mística, como a alquimia - cuja simbologia nos possibilitou compreender muitas das imagens cifradas de A Rosa do Povo.

Embora o ceticismo de Drummond se mostre muitas vezes até mesmo violento, numa tensão ininterrupta entre um discurso esperançoso e a recusa a qualquer possibilidade de reconciliação da arte com o contexto histórico, a sensação final da leitura de A Rosa do Povo é a de que a esperança, tal como o orvalho de "Consideração do poema”, banhará o pó da terra devastada, adubando-o, para que dele nasçam novas formas de vida. 


\section{Bibliografia}

\section{Obras de Carlos Drummond de Andrade}

DRUMMOND DE ANDRADE, Carlos. Confissões de Minas. Rio de Janeiro: Americ=Edit., 1944. . A Rosa do Povo. Rio de Janeiro: José Olympio, 1945. . Passeios na Ilha. Rio de Janeiro: "Organização Simões”, 1952. . Fazendeiro do ar \& Poesia até agora. Rio de Janeiro: José Olympio, 1955. . Lição de coisas. Rio de Janeiro: José Olympio, 1962. . Tempo, vida, poesia. Rio de Janeiro: Record, 1987. . A Rosa do Povo. Rio de Janeiro: Record, 1993. . Claro enigma. Rio de Janeiro: Record, 1993. . Sentimento do mundo. Rio de Janeiro: Record, 1999. . Carlos e Mário: correspondência entre Carlos Drummond de Andrade inédita - e Mário de Andrade: 1924-1945; organização Lélia Coelho Frota; apresentação e notas às cartas de Mário de Andrade: Carlos Drummond de Andrade; prefácio e notas às cartas de Carlos Drummond de Andrade: Silviano Santiago. Rio de Janeiro: Bem-Te-Vi Produções Literárias, 2002a.

. Drummond, uma visita. Rio de Janeiro: Fundação Casa de Rui Barbosa, 2002b. . Inventário do arquivo. Rio de Janeiro: Fundação Casa de Rui Barbosa, 2002c. . Poesia completa. Rio de Janeiro: Nova Aguilar, 2003a. . Prosa Seleta. Rio de Janeiro: Nova Aguilar, 2003 b. . Confissões de Minas. São Paulo: Cosac Naify, 2011a. . Passeios na ilha. São Paulo: Cosac Naify, 2011 b. Poesia traduzida. São Paulo: Cosac Naify, 2011c. . Poesia 1930-62: de Alguma poesia a Lição de coisas. Edição crítica preparada por Júlio Castañon Guimarães. São Paulo: Cosac Naify, 2012.

\section{Sobre Carlos Drummond de Andrade}

ANDRADE, Mario de. A lição do amigo: cartas de Mário de Andrade a Carlos Drummond de Andrade, anotadas pelo destinatário. Rio de Janeiro: J. Olympio, 1982.

ARRIGUCCI Jr., Davi. Coração Partido. São Paulo: Cosac \& Naify, 2002.

BISHOF, Betina. Razão da Recusa: um estudo da poesia de Carlos Drummond de Andrade. São 
Paulo: Nankin, 2005.

BUARQUE DE HOLANDA, Sérgio. O Espírito e a Letra, vol. 2. São Paulo: Companhia das Letras, 1996.

CAMILO, Vagner. Drummond, da Rosa do Povo à Rosa das Trevas. São Paulo: Ateliê Editorial, 2001 .

. "Uma poética da indecisão: Brejo das Almas". Novos Estudos Cebrap, n. 57, julho 2000, pp. 37-58.

CANÇADO, José Maria. Os sapatos de Orfeu. São Paulo: Scritta, 1993.

CANDIDO, Antonio. “Inquietudes na poesia de Drummond”. In: Vários Escritos. São Paulo: Duas Cidades, 2004.

. "Drummond prosador", em Recortes. São Paulo: Companhia das Letras, 1993.

CARPEAUX, Otto Maria. Ensaios Reunidos, vol. I, Rio de Janeiro: UniverCidade Editora e Topbooks, 1999.

CASTELLI, Chantal. Lembranças em conflito: Poesia, Memória e História em Boitempo.

Dissertação de mestrado apresentada ao programa de pós-graduação em Teoria Literária e Literatura Comparada da FFLCH-USP em 2002. . Sobre toda ruína: figurações da utopia em Lição de Coisas, de Carlos Drummond de Andrade. Tese de doutorado apresentada ao programa de pós-graduação em Teoria Literária e Literatura Comparada da FFLCH-USP em 2010.

FERREIRA, Maria Lucia do Pazo. O erotismo nos poemas inéditos de Carlos Drummond de Andrade. Tese de doutorado apresentada na Universidade Federal do Rio de Janeiro em 1992.

GLEDSON, John. Poesia e Poética em Carlos Drummond de Andrade. São Paulo, Duas Cidades, 1981.

HANSEN, João Adolfo. "Drummond e o livro inútil”. In: DRUMMOND DE ANDRADE, Carlos. Confissões de Minas. São Paulo: Cosac Naify, 2011a.

LAFETÁ, João Luiz. "Leitura de Campos de Flores". In: A dimensão da noite e outros ensaios.

São Paulo: Duas Cidades/ Editora 34,

2004.

MERQUIOR, José Guilherme. Verso universo em Drummond; tradução de Marly de

Oliveira. Rio de Janeiro: José Olympio, Secretaria de Estado de Cultura, Ciência e Tecnologia, 1975.

MORAES NETO, Geneton. Dossiê Drummond. São Paulo: Globo, 2007.

MOURA, Murilo Marcondes de. Três Poetas Brasileiros e a Segunda Guerra Mundial [Carlos Drummond de Andrade, Cecília Meireles e Murilo Mendes]. Tese de Doutorado apresentada 
ao Departamento de Teoria Literária e Literatura Comparada da Faculdade de Filosofia, Ciências e Letras da Universidade de São Paulo em 1998.

PY, Fernando. Bibliografia comentada de Carlos Drummond de Andrade. Rio de Janeiro: Edições Casa de Rui Barbosa, 2002.

SANT’ANNA, Affonso Romano de. Drummond: o gauche no tempo. Rio de Janeiro: Record, 1992. SIMON, Iumna Maria. Drummond: uma poética do risco. São Paulo: Ática, 1978.

TALARICO, Fernando Braga Franco. História e poesia em Drummond. Bauru,SP: Edusc, 2011. VILLAÇA, Alcides. Passos de Drummond. São Paulo: Cosac \& Naify, 2006.

\section{Bibliografia geral}

ADORNO, Theodor W. Notas de Literatura I. São Paulo: Livraria Duas Cidades e Editora 34, 2003.

Teoria estética. Lisboa: Edições 70, 2008.

AGAMBEN, Giorgio. Infância e história: destruição da experiência e origem da história.

Tradução de Henrique Burigo. Belo Horizonte: Editora UFMG, 2008.

ANDRADE, Mario de. Poesias completas; edição crítica de Diléa Zanotto Manfio. Belo Horizonte: Ed. Itatiaia, 2005. . “A poesia de 30”. In: Aspectos da literatura brasileira. São Paulo: Martins, 1974.

ANDRADE, Oswald de. A utopia antropofágica. São Paulo: Globo, 1990.

ARANTES, Paulo. Ressentimento da dialética. Rio de Janeiro: Paz e Terra, 1996.

ARENDT, Hannah. Sobre a Revolução. Tradução de Denise Bottmann. São Paulo: Companhia das Letras, 2011.

AUERBACH, Erich. Ensaios de literatura ocidental. Tradução de Samuel Titan Jr. e José Marcos Mariani de Macedo. São Paulo: Duas Cidades; Ed. 34, 2007.

AZEVEDO FILHO, Leodegário A. de. Camões, o desconcerto do mundo e a estética da utopia.

Rio de Janeiro: Tempo Brasileiro, 1995.

BACHELARD, Gaston. A Poética do Espaço. Tradução Antonio de Pádua Danesi. São Paulo:

Martins Fontes, 2012.

BACZKO, Bronislaw. "Utopia”. In: Enciclopédia Einaudi-vol. 5 -Anthropos-Homem. Lisboa: Imprensa Nacional - Casa da Moeda, 1985.

BANDEIRA, Manuel. Estrela da vida inteira. Rio de Janeiro: Nova Fronteira, 1993.

BARTHES, Roland. “A morte do autor”. O Rumor da Língua. Trad. Mario Laranjeira. São Paulo: Martins Fontes, 2004, pp. 57-64.

BATAILLE, Georges. O erotismo. Tradução Cláudia Fares. São Paulo: Arx, 2004. 
BAUDELAIRE. Charles. O pintor da vida moderna. Tradução e notas Tomaz Tadeu. Belo Horizonte: Autêntica, 2010.

Flores das Flores do mal de Baudelaire. Tradução de Guilherme de Almeida. São Paulo: Editora 34, 2010.

. As Flores do mal. Tradução de Maria Gabriela Llansol. Lisboa: Relógio D’água, 2003.

BENJAMIN, Walter. Charles Baudelaire: um lírico no auge do capitalismo. Tradução de José Carlos Martins Barbosa e Hemerson Alves Baptista. São Paulo: Brasiliense, 2000. . Rua de mão única. Tradução de José Carlos Martins Barbosa e Hemerson Alves Baptista. São Paulo: Brasiliense, 2000. . Magia e técnica, arte e política. Tradução de Sergio Paulo Rouanet. São Paulo:

Brasiliense, 1996. . Origem do drama trágico alemão. Tradução João Barrento. Belo Horizonte: Autêntica Editora, 2011.

BERLIN, Isaiah. Limites da utopia: capítulos da história das idéias. Tradução Valter Lellis Siqueira. São Paulo: Companhia das Letras, 1991.

BÍBLIA SAGRADA. Tradução Domingos Zamagna e outros. Rio de Janeiro: Vozes, 2005.

BLANCHOT, Maurice. O espaço literário. Tradução de Álvaro Cabral. Rio de Janeiro: Rocco, 2011.

BLOCH, Ernst. Princípio Esperança, vol 1. tradução Nélio Schneider. Rio de janeiro: Ed. UERJ e Contraponto, 2005. . Princípio Esperança, vol 2. tradução Werner Fuchs. Rio de janeiro: Ed. UERJ e Contraponto, 2006a. Princípio Esperança, vol 3. tradução Nélio Schneider. Rio de janeiro: Ed. UERJ e Contraponto, 2006b.

BÖHME, Jacob. Aurora. Prólogo, tradução e notas de Agustín Andreu Rodrigo. Madrid: Alfaguara, 1979.

BOSI, Alfredo. O ser e o tempo da poesia. São Paulo: Companhia das Letras, 2000. . Ideologia e contraideologia. São Paulo: Companhia das Letras, 2010.

BRAGA, Rubem. A borboleta amarela. Rio de Janeiro: Record, 1979.

BRUNEL, Pierre. (org.) Dicionário de mitos literários. Tradução Carlos Sussekind. Rio de Janeiro: José Olympio, 2005.

BUARQUE DE HOLANDA, Sérgio. Raízes do Brasil. São Paulo: Companhia das Letras, 1999. Visão do Paraíso. São Paulo: Companhia das Letras, 2010.

BUBER, Martin. O Socialismo Utópico. São Paulo: Perspectiva, 1971. 
MELO NETO, João Cabral. Obra completa. Rio de Janeiro: Nova Aguilar, 1994.

CANDIDO, Antonio. Literatura e Sociedade. São Paulo: T. A. Queiroz, 2000.

. “A literatura e a formação do homem". In: Textos de intervenção. São Paulo: Duas

Cidades / Editora 34, 2002.

. Na sala de aula. Caderno de análise literária. São Paulo: Ática, 2002.

. A Educação pela Noite. Rio de Janeiro: Ouro sobre Azul, 2006a.

. Ficção e confissão. Rio de Janeiro: Ouro sobre Azul, 2006b.

CARPEAUX, Otto Maria. História da literatura ocidental, volume I. São Paulo: Leya, 2011.

CARVALHO, Raimundo Nonato Barbosa de. Metamorfoses em Tradução. Trabalho de

conclusão de pós-doutoramento apresentada ao programa de pós-graduação em Teoria Literária e Literatura Comparada da FFLCH-USP em 2010.

CHEVALIER, Jean. GHEERBRANT, Alain. Dicionário de Símbolos: (mitos, sonhos, costumes, gestos, formas, figuras, cores, números). Tradução Vera da Costa e Silva. Rio de Janeiro: José Olympio, 2002.

COMBE, Dominique. "La referencia desdobrada: el sujeto lírico entre la ficción y la autobiografia". Fernando Cabo-Aseguinolaza (org.) InTeorias sobre la lírica. Madrid: Arco Libros, 1999.

D’ANGELO, Paolo. A estética do Romantismo. Trad. Isabel Teresa Santos. Lisboa: Editorial Stampa, 1998.

ELIADE, Mircea. O Mito da Alquimia. Tradução Pedro Serras Pereira. Lisboa: Fim de Século Edições, 2000. . Tratado de História das Religiões. São Paulo: Martins Fontes, 2002. . Ferreiros e alquimistas. Tradução de Carlos Pessoa. Lisboa: Relógio d’Água, s.d.

FAUSTO, Boris. História do Brasil. São Paulo: Edusp, 2007.

FOUCAULT, Michel. Estética: Literatura e pintura, música e cinema. Trad. I. A. D. Barbosa. Rio de Janeiro: Forense Universitária, 2006. . Les Mots et les Choses. Paris: Gallimard, 1966. Trecho reproduzido em: Emir R. Monegal Borges. Um Poética da Leitura. São Paulo: Perspectiva, 1980, col. Debates, n. 140. FRANÇA NETO, Oswaldo. Freud e a sublimação: arte, ciência, amor e política. Belo Horizonte: UFMG, 2007.

FRANCO JR., Hilário. As Utopias Medievais. São Paulo: Brasiliense, 1992. ."Em busca da Idade do Ouro: o papel da alquimia em Dante Alighieri”. História (Revista), São Paulo: Universidade Estadual Paulista, 1986/87.

FREUD, Sigmund. O mal estar na civilização, novas conferências introdutórias à psicanálise e outros textos. Tradução de Paulo César de Souza. São Paulo: Companhia das Letras, 2010. FRIEDRICH, Hugo. Estrutura da lírica moderna. Tradução de Marise M. Curioni. São Paulo: Duas 
Cidades, 1978.

GRESPAN, Jorge. O negativo do capital: o conceito de crise na crítica de Marx à economia política. São Paulo: Expressão Popular, 2012.

HAMBURGER, Michael. A verdade da poesia. Tradução Alípio Correia de Franca Neto.

São Paulo: Cosac Naify, 2007.

HANSEN, João Adolfo. Alegoria - construção e interpretação da metáfora. São Paulo, SP: Hedra; Campinas, SP: Editora Unicamp, 2006.

HAUCK, Dennis William. The Emerald Tablet: alchemy for personal transformation. New York: Penguin Compass, 1999.

HEGEL, Georg. A razão na história. Introdução à filosofia da história universal. Lisboa: Edições $70,1995$.

HESÍODO. Os trabalhos e os dias: (primeira parte). Introdução, tradução e comentários Mary de Camargo Neves Lafer. São Paulo: Iluminuras, 2006.

HOBSBAWN, Eric. Era dos Extremos: o breve século XX: 1914-1991. Tradução Marcos Santarrita. São Paulo: Companhia das Letras, 2007.

HOUAISS, Antônio. Dicionário Houaiss. Rio de Janeiro: Objetiva, 2003.

HUTIN, Serge. A tradição alquímica: a pedra filosofal e o elixir da longa vida. Tradução Frederico Ozanam Pessoa de Barros. São Paulo: Editora Pensamento, 1999.

JACOBY, Russell. Imagem Imperfeita. Rio de Janeiro: Civilização Brasileira, 2007.

JAEGER, Werner Wilhelm. Paidéia: a formação do homem grego. Tradução de Artur M. Parreira. São Paulo: Martins Fontes, 2001.

JAMESON, Fredric. "Pós-modernidade e sociedade de consumo". Revista Novos Estudos CEBRAP. São Paulo, n. 12, pp. 16-26.

JUNG, C. G. Estudos alquímicos. Tradução de Dora Ferreira da Silva, Maria Luíza Appy e Margaret Makray. Petrópolis: Vozes, 2002. . Psicologia e alquimia. Tradução de Dora Ferreira da Silva, Maria Luíza Appy e Margaret Makray. Petrópolis: Vozes, 2011a. . Mysterium Coniunctionis. Tradução Dora Mariana Ferreira de Silva. Petrópolis:

Vozes, $2011 b$.

WILHELM, R. O segredo da flor de ouro: Um livro de vida chinês. Petrópolis:

Vozes, 2012.

KAYSER, Wolfgang. Interpretação e análise da obra literária. Coimbra: Armênio Amado Editora, 1968.

LACLOS, Choderlos de. As relações perigosas. Tradução de Carlos Drummond de Andrade. São Paulo: Globo, 1993. 
LAUBERG, Heinrich. Elementos de Retórica Literária. Tradução R. M. Rosado Fernandes. Lisboa: Fundação Calouste Gulbenkian, 2011.

LÖWY, Michel. Romantismo e messianismo: ensaios sobre Lukács e Walter Benjamin. Trad. Myrian Veras Baptista e Magdalena Pizante Baptista. São Paulo: Perspectiva e Edusp, 1990. . "Ernst Bloch y Adorno: las luces del Romanticismo". In Salamandra. Madrid:

Ediciones de la Torre Magnética, 2010-2011. . A teoria da revolução no jovem Marx. Tradução Anderson Gonçalves. São Paulo: Boitempo, 2012.

LUKÁCS, Georg. História e Consciência de Classe: estudos sobre a dialética marxista. Tradução de Rodnei Nascimento. São Paulo: Martins Fontes, 2003.

. A teoria do romance: um ensaio histórico-filosófico sobre as formas da grande épica. Tradução de José Marcos Mariani de Macedo. São Paulo: Editora 34 e Livraria Duas Cidades, 2006.

MAGRIS, Claudio. “O romance é concebível sem o mundo moderno?”. In: Franco Moretti, org. A cultura do romance. Vol. 1. Trad. Denise Bottmann. Cosac Naify, 2009, 1013-1028.

MALLARMÉ, Stéphane. Poesias. Tradução José Augusto Seabra. Lisboa: Assírio \& Alvim, 2004. . Divagações. Tradução Fernando Scheibe. Florianópolis: Editora UFSC, 2010.

MANNHEIM, Karl. Ideologia e Utopia. Tradução de Sérgio Magalhães Santeiro. Rio de Janeiro: Zahar, 1972.

MARCUSE, Herbert. O fim da Utopia. Tradução Carlos Nelson Coutinho. Rio de Janeiro:

Paz e Terra, 1969. Razão e Revolução. Rio de Janeiro: Paz e Terra, s.d.

MARX, Karl Heinrich. ENGELS, Friedrich. Manifesto do Partido Comunista. São Paulo: Global, 2006.

. A ideologia alemã. São Paulo: Boitempo, 2007.

O Dezoito Brumário de Louis Bonaparte. Tradução Sílvio Donizete Chagas. São Paulo: Centauro, 2008. O Capital. São Paulo: Abril, coleção os Economistas, 1983.

MENDES, Murilo. “A Poesia Social”, em Cecília Meireles, Obra Poética, Rio de Janeiro: Aguilar, 1972.

Poesia Completa e Prosa. Rio de Janeiro: Nova Aguilar, 2006.

Recordações de Ismael Nery. São Paulo: Edusp e Ed. Giordano, 1996.

MESCHONNIC, Henri. “O poema como utopia”. In: RIOT-SARCEY, Michele; BOUCHET, Thomas; PICON, Antoine. Dicionário de Utopias. Tradução de Carla Bogalheiro Gamboa e Tiago Marques. Lisboa: Edições Texto \& Grafia, 2009. 
MICELI, Sérgio. Intelectuais e classes dirigentes no Brasil. São Paulo: Difel, 1979.

MOISÉS, Carlos Felipe. Poesia e utopia: sobre a função social da poesia e do poeta.

São Paulo: Escrituras, 2007.

MORE, Thomas. Tradução de Jefferson Luiz Camargo e Marcelo Brandão Cipolla. São Paulo: Martins Fontes, 2009.

MÜNSTER, Arno. Ernst Bloch: filosofia da práxis e utopia concreta. São Paulo: UNESP, 1993. . Utopia, messianismo e apocalipse nas primeiras obras de Ernst Bloch. Tradução de Flávio Beno Siebeneichler. São Paulo: Editora da Universidade Estadual Paulista, 1997. NIETZSCHE, Friedrich. Obras Incompletas. Trad. Rubens Rodrigues Torres Filho. São Paulo: Abril Cultural, 1983.

NOVALIS. Os Hinos da Noite. Tradução Fiama Hasse Pais Brandão. Lisboa: Assírio \& Alvim, 1998.

NOVO TESTAMENTO E SALMOS. A BÍBLIA DE JERUSALÉM. Tradução Estêvão Bettencourt e outros. São Paulo: Edições Paulinas, 1984.

PAQUOT, Thierry. A Utopia. Rio de Janeiro: Difel, 1999.

PAZ, Octavio. La otra voz. Poesia y fin de siglo. Barcelona: Editorial Seix Barral, 1990 (2 edição).

PESSOA, Fernando. Obras em prosa. Rio de Janeiro: Nova Aguilar, 1998. Obra poética. Rio de Janeiro: Nova Aguilar, 2005. . "A química oculta, ou alquimia, difere da química vulgar". In: http://arquivopessoa.net/textos/662, acessado em 07.07.2013.

PÉCORA, Alcir. Teatro do Sacramento. Campinas, SP: Editoras da Unicamp e da USP, 2008.

PETRARCA, Francesco. Tradução Luís de Camões. São Paulo: Hedra, 2006.

REICH, Wilhelm. Psicologia de massas do fascismo. Tradução Maria da Graça M. Macedo. São Paulo: Martins Fontes, 2001.

RENAULT, Abgar (org. e trad.). Poemas Ingleses de Guerra. Rio de Janeiro: Jornal do Comércio, 1942.

RIBEIRO, Renato Janine. “O novo e o 'pathos' (em torno do 'Dezoito Brumário')”. A última razão dos reis: ensaios sobre filosofia e política. São Paulo: Companhia das Letras, 1993.

RIOT-SARCEY, Michele; BOUCHET, Thomas; PICON, Antoine. Dicionário de Utopias. Tradução de Carla Bogalheiro Gamboa e Tiago Marques. Lisboa: Edições Texto \& Grafia, 2009.

ROUGEMONT, Denis de. O amor e o Ocidente. Tradução de Paulo Brandi e Ethel Brandi Cachapuz. Rio de Janeiro: Editora Guanabara, 1988. 
ROUSSEAU, Jean-Jacques. Discurso sobre a origem e os fundamentos da desigualdade entre os homens. Trad. Maria Ermantina Almeida Prado Galvão. São Paulo: Martins Fontes, 2005.

. Confissões. Tradução Rachel de Queiroz e José Benedito Pinto. Bauru, SP: Edipro, 2008.

SPINA, Segismundo. Manual de Versificação Românica Medieval. São Paulo: Ateliê Editorial, 2003 .

SOUZA, Gilda de Mello. O tupi e o alaúde: uma interpretação de Macunaíma. São Paulo: Duas Cidades, 1979.

VERNANT, Jean-Pierre. 2006. O universo, os deuses, os homens. Tradução Rosa Freire d'Aguiar. São Paulo: Companhia das Letras, 2006a.

. Mito e sociedade da Grécia Antiga. Tradução Myriam Campello. Rio de Janeiro: José Olympio, 2006b. 